\title{
ESTUDO MICROBIOLÓGICO DA INFLUÊNCIA DA ADIÇÃO QUÍMICA DE ÁCIDO FÓLICO EM SISTEMAS DE LODOS ATIVADOS
}

Dissertação apresentada à Escola Politécnica da Universidade de São Paulo para obtenção do título de Mestre em Engenharia

São Paulo 


\section{DANIELLE PIRES DE CAMARGO TORRES}

\section{ESTUDO MICROBIOLÓGICO DA INFLUÊNCIA DA ADIÇÃO QUÍMICA DE ÁCIDO FÓLICO EM SISTEMAS DE LODOS ATIVADOS}

Dissertação apresentada à Escola Politécnica
da Universidade de São Paulo como parte
dos requisitos para obtenção do título de
Mestre em Engenharia.

Área de Concentração:

Engenharia Hidráulica e Sanitária

Orientador:

Prof Dr. Roque Passos Piveli 
Ao Gledson, meu grande amor e amigo, com gratidão e admiração pelo seu enorme apoio, incentivo e compreensão durante todas as etapas do mestrado. 


\section{AGRADECIMENTOS}

A Deus, pela possibilidade de concluir mais este desafio, dando-me saúde, luz e persistência.

À Profa. Dra. Rosana Filomena Vazoller, pela orientação, incentivo, amizade e dedicação dispensados durante o trabalho e sobretudo ao seu grande apoio e atenção durante uma fase muito difícil da minha vida pessoal, em que me faltou o essencial - a saúde !

Ao Prof. Dr. Roque Passos Piveli, pela atenção, orientação, amizade, sugestões e conselhos, e por partilhar seus conhecimentos e sua experiência, sempre atencioso e receptivo.

Ao Prof. Dr. Pedro Alem Sobrinho, pelo apoio e contribuição durante o Mestrado.

Aos funcionários do Centro Tecnológico de Hidráulica da Escola Politécnica da USP, em especial ao Sr. Adhemar Paulo Rizolli, pelo suporte técnico na construção da unidade piloto.

Ao Laboratório de Saneamento da Escola Politécnica da Universidade de São Paulo "Professor Lucas Nogueira Garcez", pelo suporte na realização das análises laboratoriais.

Aos funcionários do Laboratório de Saneamento Fábio, Laerte e Ângela, pela ajuda durante a etapa experimental da pesquisa.

Ao amigo Flávio Yoshida, que tanto me ajudou pelos caminhos da engenharia, durante o período em que cursamos as disciplinas do mestrado.

Aos amigos com quem convivi e partilhei da mesma experiência no Laboratório de Saneamento, pela amizade, companheirismo e colaboração na rotina de laboratório: André Negrão, Ricardo Nagamine Constanzi, Adriana Hélia Caseiro, Lucia Naomi Asada, Ruy Scanho, Luciano e Carlos. 
Ao encarregado de Operação da ETE ABC, da Sabesp, Fábio Ferreira de Carvalho, pela colaboração na coleta e envio das amostras de lodo utilizadas como inóculo em todos os bioensaios.

À Rosa, do Laboratório de Microbiologia Ambiental do Instituto de Ciências Biomédicas da USP, pela sua atenção e orientação quanto à técnica de fixação e coloração de lâminas, e pela concessão de alguns materiais necessários.

À Ana Carolina, doutoranda do Laboratório de Microbiologia Ambiental do Instituto de Ciências Biomédicas da USP, pela sua extrema atenção e dedicação ao introduzir-me à prática de técnica molecular.

À bióloga Maria da Glória Figueiredo, da Cetesb, pelo pronto atendimento no fornecimento de alguns reagentes para a realização de procedimentos de uma parte experimental da pesquisa.

À Coordenação de Aperfeiçoamento de Pessoal de Nível Superior (CAPES), pela concessão de bolsa de mestrado, e pelo apoio financeiro para a realização desta pesquisa.

Ao meu amor e amigo Gledson, pelo incansável apoio, incentivo, paciência e colaboração durante todo o mestrado, inclusive pela sua ajuda nas tarefas de operação dos reatores e análises no laboratório em todos os sábados desta etapa da pesquisa.

À minha irmã Daiane, a técnica que por alguns meses foi minha estagiária, auxiliando muito durante a etapa de operação dos reatores, dividindo comigo as muitas e exaustivas tarefas diárias, entre elas o preparo de efluente sintético para alimentação dos reatores, descarte manual de lodo, análises químicas, etc, etc, etc,...

Aos meus pais, Nanci e Tadeu, e à minha irmã "gêmea" Renata, pelo apoio, carinho, compreensão, alegria contagiante e incentivo, pelas palavras sempre animadoras diante das dificuldades que apareceram pelo caminho.

E a todos que contribuíram de alguma maneira para a realização deste trabalho. 
"Como organismos biológicos, feitos de matéria, somos sujeitos às leis da biologia e da física; como pessoas conscientes, criamos nossa própria história e somos livres para decidir como esta história deve ser." (Auden, W.H. Mundos Imaginados) 


\section{RESUMO}

TORRES, D.P.C. Estudo microbiológico de sistemas de lodos ativados com adição química de ácido fólico. 2005. 184 f. Dissertação (Mestrado) - Escola Politécnica, Universidade de São Paulo, São Paulo, 2005.

O ácido fólico é uma vitamina essencial a reações do metabolismo e crescimento das células, ao promover a síntese de proteínas para a divisão celular. Segundo pesquisas, a aplicação deste no reator de lodos ativados pode contribuir na otimização do tratamento biológico. A parte experimental deste trabalho foi desenvolvida em duas etapas: bioensaios de respirometria sob condições aeróbias, a fim de avaliar os efeitos da adição de ácido fólico na atividade metabólica da microbiota de lodos ativados; e operação de estação piloto de lodos ativados em batelada, para avaliar a influência do ácido fólico na dinâmica da microfauna e no desempenho geral do tratamento. Nos bioensaios de respirometria destacou-se o consumo de oxigênio diante da adição da maior concentração testada - 4,0 mg/L de ácido fólico, com o consumo de até $78 \%$ de oxigênio, enquanto que nos frascos controles o consumo médio foi de $50 \%$. O composto Dosfolat, empregado na concentração $2,5 \mathrm{mg} / \mathrm{L}$, também estimulou a respiração basal da microbiota de lodos estudados, como observado pelo consumo de $100 \%$ do oxigênio presente após 24 horas de incubação dos sistemas de respirometria. Nos sistemas de lodos ativados em batelada, o ácido fólico e o composto Dosfolat não exerceram influência na eficiência do tratamento e na produção de lodo excedente. Em relação aos aspectos da microbiologia dos sistemas, a adição de ambas as soluções não ocasionou diferenças na composição e diversidade da microfauna, e não influenciou a dinâmica de crescimento das bactérias filamentosas. Porém, nos reatores que receberam adição de ácido fólico e Dosfolat os flocos apresentaram tamanhos superiores, e melhores características morfológicas em relação aos do lodo do reator controle.

Portanto, as taxas de respiração observadas com a adição de ácido fólico e de Dosfolat em sistemas de lodos ativados indicam uma tendência de estímulo da atividade metabólica como resposta ao incremento de ácido fólico. Além deste fator, sugere-se que a utilização de ambas as soluções favorece o crescimento das bactérias dos flocos e a formação destes, em detrimento às bactérias livres.

Palavras-chave: Lodos ativados, Ácido fólico, Microbiologia de lodos ativados. 


\begin{abstract}
TORRES, D.P.C. Microbiologic study of activated sludge process with chemical addition of folic acid. 2005. 183 f. Dissertação (Mestrado) - Escola Politécnica, Universidade de São Paulo, São Paulo, 2005.
\end{abstract}

The folic acid is a essential vitamin to metabolism and growth of the cells by promoting the synthesis of proteins for the cellular division. According to some researches, this application in the activated sludge systems can contribute to in the optimization of the biological treatment. The experimental part of this work was developed in two stages: aerobic respirometry biotests, in order to evaluate the effects of the addition of folic acid in the metabolic activity of the microbiotica of activated sludge; and operation of a pilot plant of activated sludge, to evaluate the influence of the folic acid in microorganisms's dynamics and the performance of the treatment. In the respirometric bioassays was eminence the consumption of oxygen with addition of the highest concentration tested was added - 4.0 $\mathrm{mg} / \mathrm{L}$ of folic acid, where the consumption of up to $78 \%$ of oxygen was observed, whereas in the control the flocs the consumption was $50 \%$. The composed Dosfolat, employee in the concentration 2,5 mg/L, also contribute the microbiota's activity of the of sludge, as observed by the consumption of $100 \%$ of the present oxygen after 24 hours of incubation of the respirometric systems. In the activated sludge systems, the folic acid and Dosfolat didn't exercise influence in the efficiency of the treatment and in the production of sludge. In relation to the aspects of the microbiology, the addition of both solutions didn't cause differences on the composition and microorganisms's diversity, and it didn't influence the dynamics of growth of the filamentous bacterias. Even so, the reactors that received addition of folic acid and Dosfolat the flocs presented superior sizes, and improve morphologic characteristics in relation to sludge of the control reactor.

Therefore, the breathing rates observed with addition of folic acid and of Dosfolat in activated sludge systems indicate a tendency of incentive of the metabolic activity as answer to the increment of folic acid. Besides this factor, suggests that the use of both solutions favors bacteria growth of the flocs and this formation of these, in detriment to the free bacterias.

Keywords: Activated sludge, Folic acid, Microbiology of activated sludge 
AUTORIZO A REPRODUÇÃO E DIVULGAÇÃO TOTAL OU PARCIAL DESTE TRABALHO, POR QUALQUER MEIO CONVENCIONAL OU ELETRÔNICO, PARA FINS DE ESTUDO E PESQUISA, DESDE QUE CITADA A FONTE.

Este exemplar foi revisado e alterado em relação à versão original, sob responsabilidade única do autor e com a anuência de seu orientador.

São Paulo, 30 de abril de 2006.

Assinatura do autor

Assinatura do orientador

FICHA CATALOGRÁFICA

Torres, Danielle Pires de Camargo

Estudo microbiológico de sistemas de lodos ativados com adição química de ácido fólico / D.P. de C. Torres. -- ed.rev. São Paulo, 2006.

$179 \mathrm{p}$.

Dissertação (Mestrado) - Escola Politécnica da Universidade de São Paulo. Departamento de Engenharia Hidráulica e Sanitária.

1.Lodo ativado (Tratamento biológico; Microbiologia) 2.Tratamento de esgotos sanitários (Microbiologia) I.Universidade de São Paulo. Escola Politécnica. Departamento de Engenharia Hidráulica e Sanitária II.t. 


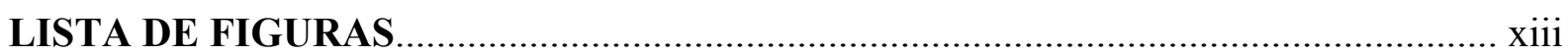

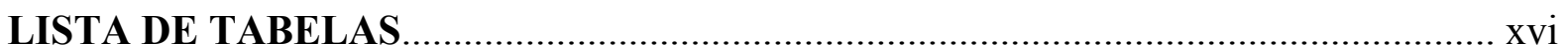

LISTA DE ABREVIATURAS E SIGLAS ....................................................... xix

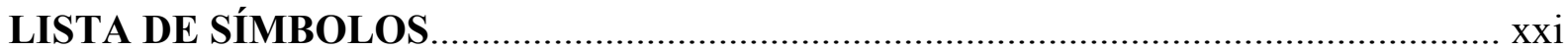

1. INTRODUÇÃ

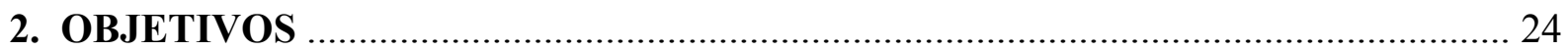

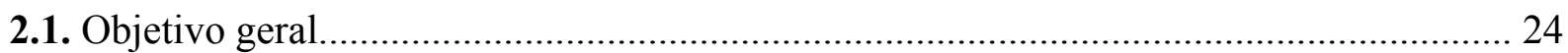

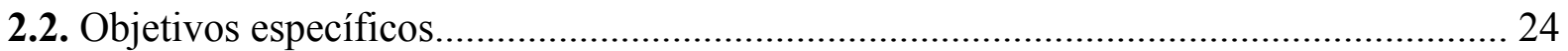

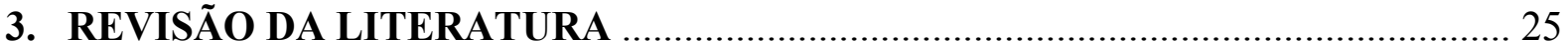

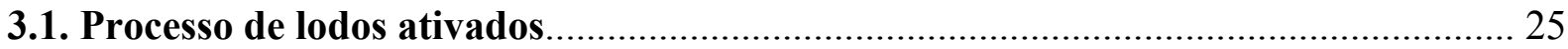

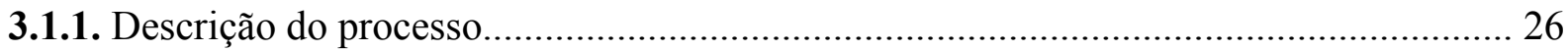

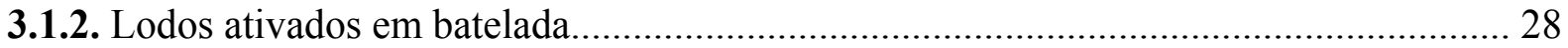

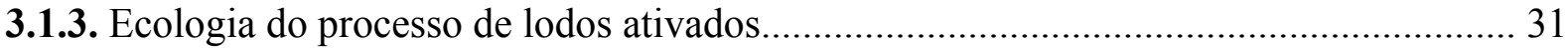

3.1.4 Oxidação da matéria orgânica em sistemas biológicos de tratamento de águas

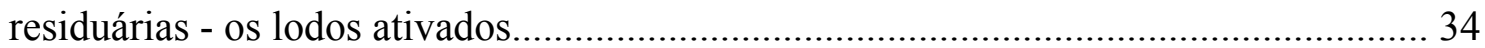

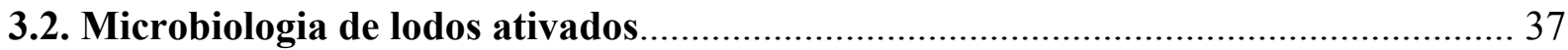

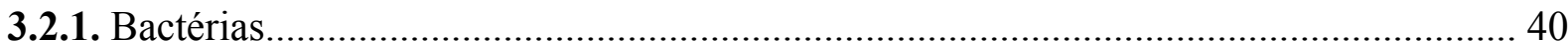

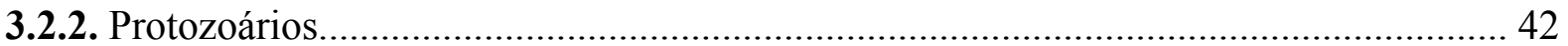


3.2.3. Micrometazoários

3.2.4. Fungos.

3.3. O floco de lodos ativados.

3.4. Bactérias filamentosas e o fenômeno de intumescimento. 60

3.5. Aplicação e influência do ácido fólico em reatores de tratamento biológico de esgotos de lodos ativados. 65

3.5.1. Características do ácido fólico 67

3.5.2. Importância e metabolismo do ácido fólico nos organismos 70

3.5.3. Características do composto a base de ácido fólico empregados em ETEs. 75

3.5.3.1. Resultados verificados com a utilização do produto a base de ácido fólico empregado em ETEs

3.6. Bioensaios de respirometria.

4. MATERIAL E MÉTODOS. 82

4.1. Considerações gerais. 82

4.2. Bioensaios de respirometria. 82

4.2.1. Origem do lodo utilizado como inóculo nos ensaios 83

4.2.2. Descrição dos bioensaios de respirometria. 84

4.2.3. Preparo da solução de ácido fólico e de Dosfolat. 87

4.2.4. Exames microscópicos de caracterização das amostras de lodo utilizadas nos bioensaios 88 
4.3.2. Alimentação dos reatores

4.3.3. Soluções de ácido fólico e de Dosfolat aplicadas nos reatores 95

4.3.4. Análises de monitoramento. 96

4.3.4.1. Exame qualitativo da microfauna 99

4.3.4.2. Identificação de bactérias filamentosas. 106

4.3.4. . Técnicas de colorações para identificação de bactérias filamentosas 110

5. RESULTADOS E DISCUSSÃO 117

5.1. Bioensaios de respirometria na presença de ácido fólico 119

5.1.1. Bioensaios 1

5.1.2. Bioensaios 2

5.1.3. Bioensaios 3

5.1.4. Bioensaios 4 123

5.1.5. Bioensaios 5 125

5.1.6. Observações do exame microscópico do lodo utilizado como inóculo nos bioensaios de respirometria. 128

5.2. Experimento de lodos ativados em batelada seqüencial (sistemas descontínuos). 132

5.2.1. Resultados relativos aos parâmetros físico-químicos 132

5.2.1.1. Sólidos em suspensão totais no tanque de aeração. 132

5.2.1.1.1. Sólidos em suspensão voláteis no tanque de aeração (SSVTA) 134

5.2.1.1.2. Sólidos em suspensão totais no efluente final. 136 
5.2.1.3. Demanda Bioquímica de Oxigênio (DBO) 140

5.2.1.4. Nitrato. 141

5.2.1.5. Resultados relativos à sedimentabilidade do lodo 143

5.2.2. Resultados relativos às determinações de microbiologia. 145

5.2.2.1. Tamanho dos flocos biológicos 145

5.2.2.2. Comprimento das bactérias filamentosas no lodo dos reatores

5.2.2.3. Observações dos exames microscópicos dos sistemas de lodos ativados. 149

5.2.2.4. Aspectos da microbiologia de lodos ativados apresentados como resultados de pesquisas que aplicaram ácido fólico e Dosfolat em reatores destes sistemas 155

5.2.2.5. Fotomicrografias mostrando o aspecto do lodo dos reatores 158

6. CONCLUSÕES. 161

7. RECOMENDAÇÕES 163

8. REFERÊNCIAS DE LITERATURA. 164

9. ANEXO. 174

ANEXO 1 - Tabelas com resultados dos bioensaios de respirometria 175 


\section{LISTA DE FIGURAS}

Figura 1- Representação esquemática do princípio de funcionamento do sistema convencional de lodos ativados.

Figura 2 - Ciclos de tratamento do sistema de aeração prolongada de ciclo intermitente 29

Figura 3 - Resumo das características morfológicas e de coloração de organismos filamentosos comumente observados em lodos ativados

Figura 4 - Chave dicotômica para identificação de organismos filamentosos em lodos ativados

Figura 5 - Estrutura química do ácido fólico. 68

Figura 6 - Etapas da reação de redução de ácido fólico a tetraidrofolato. 71

Figura 7 - Importância do ácido tetraidrofólico aos microrganismos. 72

Figura 8 - Reações dependentes do tetraidrofolato. 72

Figura 9 - Vista dos frascos de DBO em incubação a $20^{\circ} \mathrm{C}$, durante bioensaio de respirometria

Figura 10 - Vista do microscópio óptico de contraste de fase utilizado.

Figura 11 - Esquema representativo dos reatores de lodos ativados e suas dimensões. 90

Figura 12 - Vista frontal do sistema de reatores de lodos ativados instalados em bancada, em ciclo de aeração e mistura da massa líquida, pelos aeradores ligados

Figura 13 - Vista dos reatores com aeradores desligados, para descarte do efluente tratado (sobrenadante)

Figura 14 - Representação esquemática da planta dos reatores em batelada e os difusores instalados.

Figura 15 - Vista da Câmara de contagem de Sedgwick-Rafter.

igura 16 - Ilustração da Câmara de Sedgwick-Rafter, mostrando a forma de se colocar a amostra com pipeta 
Figura 17 - Formulário para exame microscópico (pag.1/2).

Figura 18 - Formulário para exame microscópico (pag.2/2)

Figura 19 - Formulário para caracterização e identificação de bactérias filamentosas através de análise da amostra viva (pag.1/2) 108

Figura 20 - Formulário para caracterização e identificação de bactérias filamentosas através de análise de amostra fixada (pag.2/2).

Figura 21 - Consumo de oxigênio durante o Bioensaio 1, em frascos com adição de 1,0 mg/L e 2,0 mg/L de ácido fólico e em frascos controle. 120

Figura 22 - Consumo de oxigênio durante o Bioensaio 2, em frascos com adição de 2,5 mg/L e 4,0 mg/L de ácido fólico e em frascos controle......

Figura 23 - Consumo de oxigênio durante o Bioensaio 3, em frascos com adição de 2,5 mg/L e 4,0 mg/L de ácido fólico e em frascos controle.

Figura 24 - Consumo de oxigênio durante o Bioensaio 4, em frascos com adição de 0,5, 2,5 $\mathrm{mg} / \mathrm{L}$ e $4,0 \mathrm{mg} / \mathrm{L}$ de ácido fólico e em frascos controle......

Figura 25 - Consumo de oxigênio durante o Bioensaio 5, em frascos com adição de 2,5 mg/L de ácido fólico, e em frascos controle.

Figura 26 - Vista do lodo biológico da ETE ABC, apresentando boas características, onde se observa um rotífero próximo ao centro do campo.

Figura 27 - Aspecto da comunidade do lodo da ETE ABC...... 129

Figura 28 - Protozoário ciliado pedunculado, Opercularia spp, entre os flocos do lodo..... 130

Figura 29 - Flocos do lodo, onde se observa no centro do campo um tardígrado com ovos, entre flocos.

Figura 30 - Fauna típica da amostra de lodos ativados da ETE ABC, mostrando Vorticella sp entre flocos.

Figura 31 - Fotomicrografia mostrando organismos presentes no lodo biológico da ETE

$\mathrm{ABC}$. 
Figura 32 - Variação da concentração de sólidos em suspensão totais nos reatores em função do tempo.

Figura 33 - Variação da concentração de sólidos em suspensão voláteis nos reatores em função do tempo

Figura 34 - Variação da concentração de sólidos em suspensão totais no efluente final dos reatores em função do tempo.

Figura 35 - Concentração de DQO no efluente final dos reatores.

Figura 36 - Variação da eficiência de remoção de DQO (\%) no efluente final dos reatores durante o período de operação.

Figura 37 - Concentração de nitrato (mg/L) no efluente final dos reatores......

Figura 38 - Variação do índice volumétrico de lodo (IVL) dos reatores no decorrer do período

Figura 39 - Variação do tamanho médio dos flocos biológicos do lodo dos reatores. 146

Figura 40 - Comprimento total das filamentosas $(\mathrm{m} / \mathrm{L})$ presentes no lodo dos reatores.... 148

Figura 41 - Flocos do lodo do Tanque Controle, onde se observa próximo ao centro do campo um ciliado (40X) 158

Figura 42 - Anelídeo entre os flocos do Tanque Controle (40X)...... 158

Figura 43 - Fotomicrografia mostrando flocos do Tanque com Ácido Fólico, visivelmente maiores que os do Tanque Controle (40X).

Figura 44 - Flocos do tanque com ácido fólico, e observa-se a presença de um tardígrado (contraste de fase, 100X)

Figura 45 - Aspecto do lodo do Tanque com Dosfolat (40X). 160

Figura 46 - Aspecto do lodo do Tanque com Dosfolat, onde se observa dois grandes ciliados entre os flocos (100X) 


\section{LISTA DE TABELAS}

Tabela 1 - Microrganismos indicadores das condições de depuração, segundo as características do processo.

Tabela 2 - Gêneros de bactérias comumente encontrados em lodos ativados.

Tabela 3 - Reações promovidas pelos principais gêneros de bactérias encontradas em lodos ativados

Tabela 4 - Relação entre o desempenho do sistema de lodos ativados e a presença de grupos de protozoários dominantes na microfauna.

Tabela 5 - Relação entre os tamanhos dos flocos e as características do lodo 59

Tabela 6 - Critérios de avaliação microscópica para definição da qualidade do lodo. 59

Tabela 7 - Características dos ensaios de DBO efetuados. 85

Tabela 8 - Concentrações de ácido fólico e os volumes de solução equivalentes. 88

Tabela 9 - Composição do substrato sintético simulando esgoto sanitário. 94

Tabela 10 - Parâmetros análíticos do monitoramento dos reatores e freqüência de amostragem.

Tabela 11 - Consumo total de oxigênio (\%) nos frascos do Bioensaio 1. 120

Tabela 12 - Consumo total de oxigênio (\%) nos frascos do Bioensaio 2.

Tabela 13 - Consumo de oxigênio (\%) diário nos frascos do Bioensaio 3.

Tabela 14 - Consumo de oxigênio (\%) diário nos frascos do Bioensaio 4 124

Tabela 15 - Consumo de oxigênio (\%) diário nos frascos do Bioensaio 5. 126

Tabela 16 - Concentração de sólidos em suspensão totais no lodo dos reatores com adição de ácido fólico e de Dosfolat, comparados ao controle.

Tabela 17 - Concentração de sólidos em suspensão voláteis no lodo dos reatores. 134

Tabela 18 - Concentração de SST no efluente final dos reatores 136 
Tabela 19 - Concentração de DQO no efluente final dos reatores e respectiva eficiência de remoção

Tabela 20 - Resultados de DBO x DQO dos efluentes dos reatores, e respectivas eficiências de remoção. 140

Tabela 21 - Concentração de nitrato $(\mathrm{mg} / \mathrm{L})$ no efluente final dos reatores. 141

Tabela 22 - Índice volumétrico de lodo (IVL) e relação com SSTA dos reatores durante o ensaio.

Tabela 23 - Variação do tamanho ( $\mathrm{m}$ ) dos flocos biológicos do lodo dos reatores no decorrer do período. 145

Tabela 24 - Comprimento total das filamentosas ( $\mathrm{m} / \mathrm{L}$ ) presentes no lodo dos reatores. 147

Tabela 25 - Resultados dos exames microscópicos dos lodos ativados dos reatores controle, com adição de ácido fólico e com adição da mistura Dsfolat. 149

Tabela 26 - Aspectos da microbiologia do lodo relatados em outras pesquisas como resultados da aplicação de ácido fólico em reatores de lodos ativados. .155

Tabela 27 - Parâmetros operacionais e características dos reatores desta pesquisa e das pesquisas citadas que realizaram aplicação de ácido fólico em reatores de tratamento de lodos ativados.

Tabela 28 - Bioensaio de respirometria 1, apresentando os resultados de consumo de oxigênio e de DBO em frascos com adição de 1,0 e 2,0 mg/L de ácido fólico, comparados a frascos controle.

Tabela 29 - Bioensaio de respirometria 2, apresentando os resultados do consumo de oxigênio e DBO obtidos em frascos com adição de 2,5 e 4,0 mg/L de ácido fólico, comparados a frascos controle. 176

Tabela 30 - Bioensaio de respirometria 3, apresentando os resultados do consumo de oxigênio e de DBO obtidos em frascos com adição de 2,5 e 4,0 mg/L de ácido fólico, comparados a frascos controle..... 
Tabela 31 - Bioensaio de respirometria 4, apresentando os resultados de consumo de oxigênio e de DBO obtidos em frascos com adição de 0,5;2,5 e 4,0 mg/L de ácido fólico, comparados a frascos controle..................................................................... 178

Tabela 32 - Bioensaio de respirometria 5, apresentando os resultados de consumo de oxigênio e de DBO obtidos em frascos com adição de 2,5 mg/L de ácido fólico e 2,5 mg/L de Dosfolat, comparados a frascos controle.................................................... 179 


\section{LISTA DE ABREVIATURAS E SIGLAS}

A

$\begin{array}{ll}\text { A/M } & \text { relação alimento / microrganismo } \\ \text { B9 } & \text { vitamina do complexo B } \\ \text { C.F. } & \text { carbono } \\ \mathrm{C}_{1} & \text { comprimento dos filamentos } \\ \mathrm{CH}_{2} \mathrm{OH} & \text { etanol } \\ \mathrm{CH}_{3} & \text { metila } \\ \mathrm{CH}_{4} & \text { metano }\end{array}$

CHON representação de material orgânico

$\mathrm{CO}_{2} \quad$ dióxido de carbono

DBO demanda bioquímica de oxigênio

DNA ácido desoxirribonucléico

DQO demanda química de oxigênio

E efluente final (sobrenadante)

EPA Environmental Protection Agency

ETE estação de tratamento de esgoto

F fator de diluição

H hidrogênio

$\mathrm{H}_{2} \mathrm{~S} \quad$ dióxido de enxofre

HPLC High Performance Liquid Chromatography (cromatografia líquida de alta eficiência)

IVL índice volumétrico de lodo

L lodo 


\begin{tabular}{|c|c|}
\hline $\mathrm{N}_{2}$ & nitrogênio gasoso \\
\hline $\mathrm{NH}_{3}$ & amônia \\
\hline NKT & nitrogênio kjeldhal total \\
\hline $\mathrm{NO}_{3}$ & nitrato \\
\hline $\mathrm{O}_{2}$ & oxigênio \\
\hline $\mathrm{P}$ & fósforo \\
\hline PABA & ácido p-aminobenzóico \\
\hline $\mathrm{pH}$ & potencial hidrogeniônico \\
\hline PHB & polibetahidroxiburirato \\
\hline PT & fósforo total \\
\hline S & enxofre \\
\hline S.R. & Sedgwick-Rafter (câmara) \\
\hline $\mathrm{SO}_{4-}$ & sulfato \\
\hline SST & sólidos em suspensão totais \\
\hline SST & sólidos em suspensão totais \\
\hline SSTA & sólidos em suspensão totais no tanque de aeração \\
\hline SSVTA & sólidos em suspensão voláteis no tanque de aeração \\
\hline $\mathrm{TDH}$ & tempo de detenção hidráulica \\
\hline TQ AF & reator com adição de ácido fólico \\
\hline TQ controle & reator controle \\
\hline TQ Dosfolat & reator com adição de Dosfolat \\
\hline
\end{tabular}




\section{LISTA DE SÍMBOLOS}

$\begin{array}{ll}\mathrm{m} & \text { micrômetros } \\ \mathrm{kg} & \text { quilogramas } \\ \mathrm{m}^{2} & \text { metros quadrados } \\ \mathrm{m}^{3} & \text { metros cúbicos } \\ \mathrm{ml} & \text { mililitros } \\ \mathrm{mm} & \text { milímetros } \\ { }^{\circ} \mathrm{C} & \text { graus Celsius } \\ \mathrm{OD}_{\mathrm{f}} & \text { concentração final de oxigênio dissolvido } \\ \mathrm{OD}_{\mathrm{i}} & \text { concentração inicial de oxigênio dissolvido }\end{array}$




\section{INTRODUÇÃO}

Além de ser indispensável à alimentação animal e na medicina humana, o ácido fólico é bem conhecido como um promotor específico de crescimento em microbiologia industrial, devido à sua atuação como coenzima, na forma de tetraidrofolato, dando suporte às funções enzimáticas dos microrganismos, sendo essencial ao metabolismo e crescimento das células, requerido em pequenas quantidades. Muitos microrganismos sintetizam suas próprias vitaminas a partir de substâncias simples, enquanto outros requerem várias vitaminas do meio exógeno por não possuírem enzimas para os sintetizar (Black, 1996).

Embora alguns destes microrganismos sejam capazes de sintetizar vitaminas, o ácido fólico pode estar ausente ou presente somente em concentrações traços em estações de tratamento de esgotos. Assim, em concentrações muito pequenas, pode afetar o metabolismo dos microrganismos, pois a necessidade desta vitamina pode ser superior à quantidade produzida pelos microrganismos. No tanque de aeração de estações municipais de tratamento de esgotos predominantemente domésticos de lodos ativados é encontrada uma concentração média em torno de 10 a $13 \mathrm{mg} / \mathrm{L}$ de ácido fólico. Em digestores de lodo excedente ao processo de tratamento, o ácido fólico presente no lodo apresenta concentrações entre 0,3 a 0,6 mg/L (Lemmer et al, 1997).

Segundo Anderl (1987), esta vitamina também pode ter aplicação no tratamento biológico de esgotos, onde o ácido fólico adicionado no tanque de aeração demonstra poder contribuir na otimização do tratamento biológico e na redução da geração de lodo em excesso.

Este último fator representa um problema às estações de tratamento de lodos ativados, cujo 
processo apresenta como característica a elevada produção de lodo, sendo sua solução considerada um sério desafio devido aos aspectos ambientais e econômicos envolvidos, uma vez que a produção de lodo em excesso, com o conseqüente tratamento e disposição, representa cerca de $60 \%$ do custo total do tratamento (Wei et al, 2003).

A adição de ácido fólico e do produto comercial Dosfolat - solução que apresenta esta vitamina em sua composição, em sistemas de tratamento de esgotos de lodos ativados, e pesquisas relacionadas a esta prática tiveram início no final da década de 1980, cujos autores apresentaram como resultados da utilização desta vitamina a redução da geração de lodo excedente, controle do crescimento de bactérias filamentosas e aumento da eficiência de remoção de matéria orgânica. No entanto, estas pesquisas não investigaram a forma de atuação e a influência do ácido fólico no metabolismo da microbiota destes sistemas, os quais são fatores que podem esclarecer os resultados obtidos.

Esta pesquisa teve como objetivo avaliar a eficiência da adição de ácido fólico no metabolismo e crescimento da microfauna presente em sistema de tratamento de esgoto sanitário de lodos ativados, avaliando as características microscópicas do lodo, juntamente com a qualidade do tratamento, especialmente quanto à redução da geração de lodo e ao controle de bactérias filamentosas. 


\section{OBJETIVOS}

\subsection{OBJETIVO GERAL}

Verificar a influência do ácido fólico puro e do produto industrializado comercial Dosfolat $^{\circledR}$, que apresenta ácido fólico em sua composição, em sistemas de tratamento de esgotos de lodos ativados na atividade e crescimento, diversidade microbiana, bem como no metabolismo da microbiota do lodo e na formação dos flocos biológicos.

\subsection{OBJETIVOS ESPECÍFICOS}

- Avaliar o efeito do ácido fólico e de Dosfolat na microbiota, no crescimento de bactérias filamentosas, estabelecimento da microfauna e nos tipos de flocos biológicos formados no sistema;

- Avaliar a eficiência do processo de lodos ativados em resposta à adição de ácido fólico e de Dosfolat, especialmente quanto à otimização da remoção da matéria orgânica presente em efluente sintético simulando esgoto sanitário;

- Investigar a atuação do ácido fólico e de Dosfolat na geração de lodo. 


\section{REVISÃO DA LITERATURA}

\subsection{Processo de lodos ativados}

O sistema de lodos ativados é um processo biológico aeróbio que fundamenta-se no controle do crescimento de bactérias através da recirculação do lodo produzido no sistema, de modo a manter-se a maior concentração possível de microrganismos ativos no reator aerado, a fim de acelerar a remoção do material orgânico das águas residuárias (Campos, 1994 apud Mendonça, 2002). Estes microrganismos formam flocos que podem ser removidos por sedimentação em decantador secundário ou em flotador por ar dissolvido, sendo parte do lodo recirculada no reator aeróbio e parte descartada para posterior tratamento (Van Haandel \& Marais, 1999).

O processo de lodos ativados foi desenvolvido em 1914 em Manchester, Inglaterra, por Ardern \& Lockett (Metcalf \& Eddy, 1991), e atualmente é um dos processos biológicos de tratamento de águas residuárias mais empregados no mundo, sendo a alternativa utilizada em mais de 90\% das ETEs de médio e grande portes nos países desenvolvidos (Campos, 1994 apud Mendonça, 2002).

Em lodos ativados, são aplicados princípios biológicos e bioquímicos num reator desenvolvido segundo métodos e técnicas de engenharia, apresentando como características: habilidade de metabolizar um grande número de compostos orgânicos e oxidar ou reduzir substratos de composição química variada, contendo nitrogênio, fósforo, enxofre e outros; e cultura biológica de várias espécies e crescimento em flocos (Eckenfelder, 1992). 
Segundo Van Haandel \& Marais (1999), a boa qualidade do efluente final é a principal característica positiva do sistema de lodos ativados, e a razão da sua ampla utilização no tratamento de esgoto sanitário. Neste processo de tratamento, é possível obter-se um efluente com baixa concentração de matéria orgânica, podendo obter-se até $98 \%$ de eficiência na remoção de DBO, sendo esta eficiência do sistema convencional entre 85-93\%, enquanto que a do sistema de aeração prolongada é de cerca de 93-98\% de remoção de DBO (Aisse, 1985; Von Sperling, 1996). No entanto, este sistema apresenta limitações do ponto de vista econômico, devido aos altos custos de implantação, operação e manutenção, e devido à elevada produção de lodo, que ocorre pela formação de biomassa, gerando maiores custos em transporte, disposição e dificuldades de tratamento (Van Haandel \& Marais, 1999).

\subsubsection{Descrição do processo}

O processo de lodos ativados emprega uma cultura mista de organismos aeróbios para oxidar os compostos presentes no esgoto. O termo lodo ativado pode ser entendido como um processo no qual a biomassa está na forma de flocos livremente suspensos, que consistem em aglomerações de numerosas células aderidas em material extracelular, de matriz gelatinosa, tipicamente com diâmetro entre 0,2 a $1 \mathrm{~mm}$. A mistura de biomassa e esgoto é mantida em suspensão pela turbulência criada por aeradores mecânicos ou por difusores de ar, que fornecem aeração através de bolhas finas de ar, ou de oxigênio puro (Lester \& Birkett, 1999).

Em termos simples, o sucesso operacional de lodos ativados é dependente das características da biomassa, como capacidade do floco de absorver substratos, assimilação e 
oxidação de matéria orgânica e a manutenção de boa floculação para viabilizar uma sedimentação eficiente do lodo secundário. Embora o desenvolvimento e aplicação do processo de lodos ativados seja tratado como um sistema de engenharia dinâmico, deve ser enfatizado que a unidade básica da atividade para o tratamento dos esgotos é o floco, cuja formação depende do metabolismo, crescimento e propriedades físicas das células microbianas presentes (Lester \& Birkett, 1999).

No processo de lodos ativados, os flocos são posteriormente separados do efluente final por meio do processo de sedimentação; o sobrenadante desta unidade (efluente) é descartado do processo; parte da biomassa sedimentada é parcialmente retornada ao tanque de aeração, sendo misturada com o afluente que entra no reator, mantendo uma baixa relação A/M no mesmo; e a produção de células bacterianas é removida como excesso de lodo biológico ao processo. Desta forma, o processo de lodos ativados é um sistema de cultura contínua que emprega o retorno da biomassa bacteriana (Eikelboom \& Buijsen, 1981).

Há diversas variantes do processo de lodos ativados, principalmente de acordo com as características hidráulicas e tipo de aeração. O sistema convencional de lodos ativados está representado na Figura 1 (van Haandel \& Marais, 1999; von Sperling, 1997). 


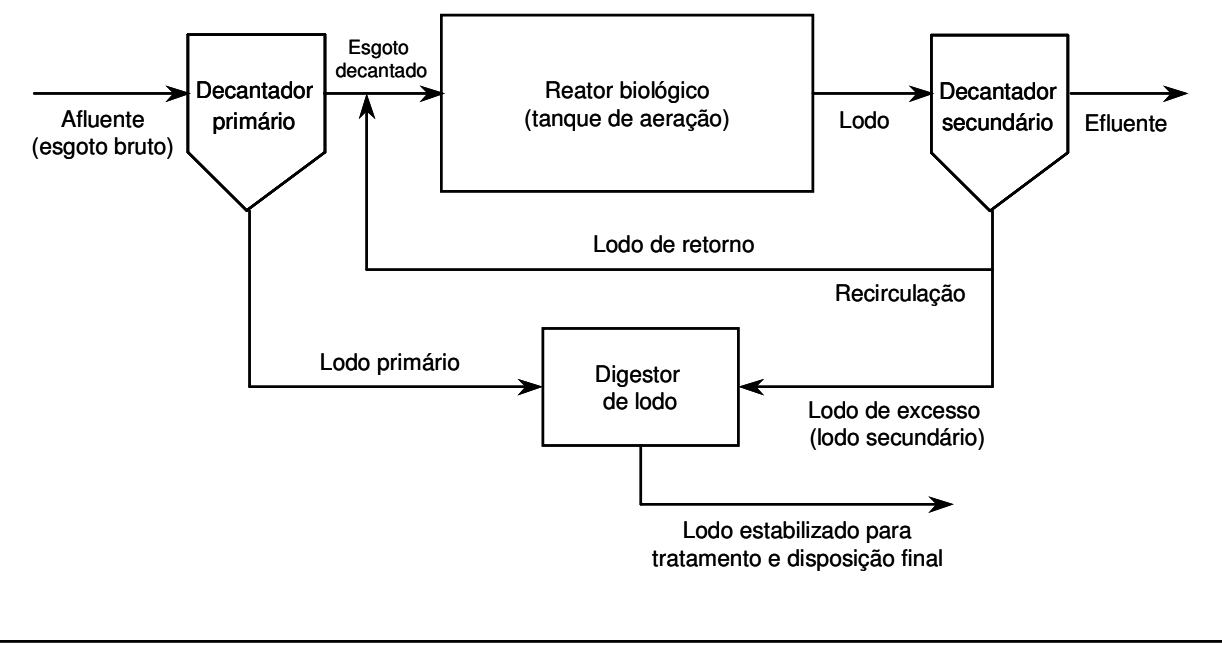

Figura 1 - Representação esquemática do princípio de funcionamento do sistema convencional de lodos ativados (Fonte: baseado em van Haandel \& Marais, 1999 e von Sperling, 1997)

\subsubsection{Lodos ativados em batelada}

O processo de lodos ativados foi inicialmente estudado como um processo de operação intermitente (batelada). Segundo Marconi (2001) apud Leung \& Tam (1994), o processo de lodos ativados em batelada é um sistema cíclico de enchimento e esvaziamento operado em um tanque simples, consistindo de um único reator de mistura completa, no qual estão integradas todas as unidades de processos e operação do sistema de tratamento convencional de lodos ativados (decantação primária, oxidação biológica e decantação secundária) em um único tanque. Assim, utilizando um tanque único estes processos passam a ser seqüências no tempo, conseguidos através do estabelecimento de ciclos de operação com durações definidas, em que a biomassa permanece no reator durante todos os ciclos (von Sperling, 1997). 
O esquema operacional é extremamente simples, no qual o tanque é preenchido com esgoto até um nível pré-determinado no reator e tratado durante um período de tempo. Depois do tratamento, a mistura é deixada em repouso para sedimentação por um período de tempo pré-determinado e o sobrenadante clarificado é retirado do tanque, restando apenas a massa de lodo biológico (Marconi, 2001 apud Kamiyama, 1989).

O sistema em batelada é formado por cinco períodos ou ciclos de tratamento, na seqüência: enchimento, reação, sedimentação, esvaziamento e repouso. Os ciclos de tratamento estão ilustrados na Figura 2, e descritos a seguir. A duração de cada ciclo pode ser alterada em função das variações da vazão afluente, das necessidades do tratamento e das características do esgoto e da biomassa do sistema (von Sperling, 1997).

ENCHIMENTO

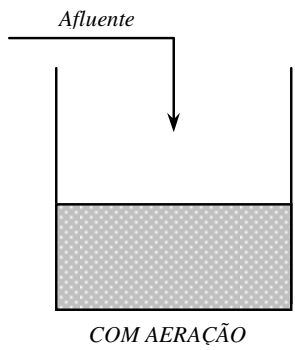

REAÇÃO

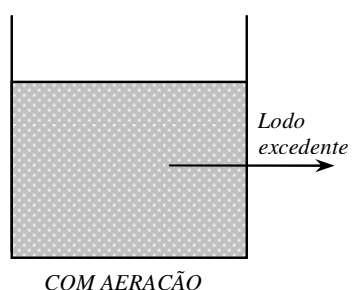

COM AERAÇÃO
SEDIMENTAÇÃO

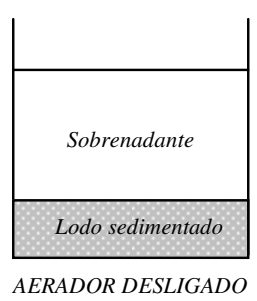

DESCARTE

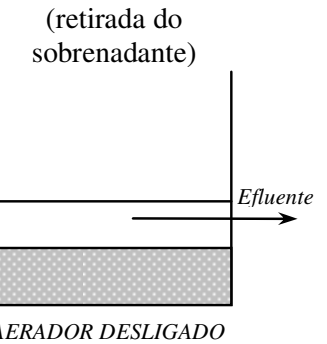

Figura 2 - Ciclos de tratamento do sistema de aeração prolongada de ciclo intermitente (Fonte: von Sperling,1997)

- Enchimento: entrada de esgoto bruto no reator, sendo estático, sem mistura e sem aeração.

- Reação: aeração e mistura da massa líquida contida no reator, promovida com os aeradores ligados. Durante este período, os sólidos estão em suspensão, em mistura completa. Não há saída de efluente destas câmaras, pois tal ocasionaria perda de 
biomassa devido ao efluente com elevada concentração de sólidos. É baseada nos objetivos do tratamento.

- Sedimentação: período em que os aeradores são desligados, principiando a sedimentação dos sólidos, para permitir a separação dos sólidos em suspensão no esgoto tratado. Após passado um período de tempo, é formada uma camada de lodo sedimentado no fundo da câmara, deixando o sobrenadante clarificado (com baixa concentração de sólidos), podendo então ter uma parte deste retirado, constituindo-se assim no efluente final.

- Descarte: ciclo em que se ocorre a retirada do efluente tratado do reator, sendo apenas com o reator parado, após a sedimentação dos sólidos. A retirada do efluente pode ser controlada manual ou automaticamente. O descarte de lodo excedente, que ocorre durante o último ciclo (repouso), tem como finalidade permitir o ajuste entre os ciclos de operação de cada reator. A quantidade e a frequiência de descarte de lodo são estabelecidas em função do crescimento da biomassa do reator.

- Repouso: é a fase final, sendo opcional, utilizada apenas em aplicações com vários tanques. Esta fase tem a finalidade de permitir o ajuste entre os ciclos de operação de cada reator. 


\subsubsection{Ecologia do processo de lodos ativados}

A população microbiana de um reator de lodos ativados é altamente especializada e a qualidade do efluente e a taxa de crescimento dos diferentes microrganismos determinam os grupos que são representados na população do lodo. Em geral, há pequena diversidade de espécies, entre as quais as bactérias gram-negativas são dominantes. Em sua maioria, são organismos heterotróficos, com exceção, por exemplo, das bactérias autotróficas nitrificantes (Horan, 1990).

As velocidades de crescimento das diferentes espécies de organismos presentes no reator geralmente apresentam grandes diferenças, sendo influenciadas pelas características ambientais, como os fatores concentração de oxigênio, pH, tipo de substrato, concentração de nutrientes disponíveis, temperatura, presença de substâncias inibidoras, e outros. Somente sob condições ambientais ótimas a taxa de crescimento de certas bactérias atinge seu máximo e como o sistema de tratamento de lodos ativados é um ambiente em que há alterações contínuas, dentro de certos limites, a população bacteriana se ajusta às alterações, decorrentes da qualidade do efluente e das influências sazonais (Eikelboom \& Buijsen, 1981). Desta maneira, uma vez que as condições ambientais são controladas adequadamente é possível efetivar a degradação do substrato controlando-se a velocidade de crescimento dos microrganismos (Crites \& Tchobanoglous, 2000 apud Mendonça, 2002).

Para garantir o crescimento dos microrganismos, estes devem permanecer no sistema durante tempo suficiente para que se reproduzam, o qual depende de sua velocidade de crescimento, sendo relacionada diretamente com a velocidade de metabolismo ou utilização do substrato (Branco, 1986). 
O crescimento dos microrganismos ocorre segundo o modelo descrito por Monod, apresentando as seguintes etapas ou fases (Branco, 1986; Vazoller, 1989):

- fase lag ou de adaptação: tempo necessário para que os microrganismos se adaptem às novas condições ambientais do meio de reação. Nesta fase não ocorre aumento do número de microrganismos, sendo a velocidade de crescimento nula;

- fase log ou exponencial: os microrganismos crescem com velocidade máxima, podendo ser representada por uma função exponencial, diante da utilização exógena de substrato disponível em abundância no meio, além de condições ambientais adequadas para sobrevivência. Nesta fase ocorre a taxa máxima de remoção de substrato;

- fase de desaceleração: a velocidade de crescimento passa a diminuir, uma vez que o substrato disponível começa a ser limitado e já existe o acúmulo de excretas tóxicas;

- fase estacionária: a velocidade de crescimento dos microrganismos reduz ao mínimo, e a concentração populacional ativa permanece estacionária, devido ao esgotamento dos substratos necessários ao crescimento ou ao acúmulo de substâncias tóxicas em níveis incompatíveis com o desenvolvimento microbiano. Nesta fase, a taxa de crescimento de novas células se equilibra com a taxa de mortalidade ou perda de viabilidade das células antigas;

- fase de declínio ou decaimento: ocorre a diminuição do número de microrganismos ativos da população, causada pela sua morte e lise celular, apresentando velocidade de crescimento negativa, ou seja, em que a taxa de mortalidade das bactérias ultrapassa a produção de células novas. 
Nas fases estacionária e de declínio ocorre o processo de metabolismo endógeno, em que as bactérias consomem suas próprias reservas protoplasmáticas como fonte de substrato e energia, pela não disponibilidade de substrato no meio (Branco, 1986; Vazoller, 1989).

A qualidade da água residuária é de grande importância à população do lodo. Em geral, ocorre competição entre os diferentes microrganismos pela disponibilidade de nutrientes, e a composição dos flocos depende do resultado desta competição. A competição pelo substrato ocorre sempre que um determinado meio constitui substrato favorável ao desenvolvimento de vários tipos de microrganismos diferentes. No entanto, quando existe uma condição desfavorável, aqueles que apresentam características capazes de sobreviver a ela passam a predominar sobre os outros (Branco, 1986).

Há uma grande variedade de compostos orgânicos que podem ser assimilados por uma grande diversidade de microrganismos. Alguns microrganismos são tipicamente onívoros, enquanto que outros são mais especializados quanto às exigências nutricionais. Quando mais de um grupo de microrganismos compete pelo mesmo substrato, o grupo que estabilizar a matéria orgânica mais completamente ou com maior produção de energia irá predominar sobre o outro (Horan, 1990).

A degradação do substrato em processo de lodos ativados é desempenhada principalmente por bactérias heterotróficas, sendo também efetuada por muitos protozoários, que são capazes de fazer nutrição sapróbica. As bactérias heterotróficas e os protozoários sapróbios formam o mais baixo nível trófico, constituindo fonte de alimento de outros organismos maiores, bem como dos próprios protozoários, além de rotíferos e nemátodos. A contribuição dessas relações é essencial ao processo de tratamento (Eikelboom \& Buijsen, 1981; Horan, 1990). 


\subsubsection{Oxidação de matéria orgânica em sistemas biológicos de tratamento de águas residuárias - os lodos ativados}

No tratamento biológico de esgotos procura-se repetir os processos de depuração que ocorrem num rio ou num lago, em ambiente restrito e em curto espaço de tempo (Branco, 1986), havendo uma interação entre diversos mecanismos para a oxidação da matéria orgânica, que ocorre simultaneamente ou seqüencialmente num reator, segundo uma grande complexidade na relação entre as diversas formas de compostos e a atuação dos microrganismos (Von Sperling, 1996).

Para isso é necessário que se proporcione na estação de tratamento as condições ideais que favoreçam a oxidação biológica, principalmente a proliferação bacteriana, uma vez que as bactérias são as principais responsáveis pela realização da depuração, como já observado, sendo o mecanismo mais importante para a degradação de matéria orgânica em sistemas biológicos de tratamento de águas residuárias é o metabolismo bacteriano, pelo qual as bactérias utilizam material orgânico como fonte de energia e para a síntese celular.

A oxidação biológica consiste em reações de conversão de compostos orgânicos complexos em substâncias de estrutura molecular simples e de baixo conteúdo energético. $\mathrm{Na}$ oxidação aeróbia, as bactérias utilizam o oxigênio molecular como aceptor final de elétrons, enquanto que, na oxidação anaeróbia, componentes como gás carbônico $\left(\mathrm{CO}_{2}\right)$, nitrato $\left(\mathrm{NO}_{3}{ }^{-}\right)$ e sulfatos $\left(\mathrm{SO}_{4}{ }^{-}\right)$são utilizados como aceptores finais de elétrons. Em ambiente anaeróbio (com potenciais de óxido redução inferiores a $-200 \mathrm{mV}$ ), sulfato e $\mathrm{CO}_{2}$ são utilizados como aceptores finais de elétrons e os principais produtos finais da oxidação da matéria orgânica são $\mathrm{CH}_{4}, \mathrm{CO}_{2}, \mathrm{H}_{2} \mathrm{~S}$ e água. Porém, em ambiente anóxico (potenciais de óxido redução entre - 
50 a $-100 \mathrm{mV}$ ), as bactérias desnitrificantes usam o nitrato, havendo formação de nitrogênio gasoso $\left(\mathrm{N}_{2}\right), \mathrm{CO}_{2}$ e água (Branco, 1986; Metcalf \& Eddy, 1991).

Assim, as reações cinéticas que ocorrem em processos de tratamento de esgotos são complexas, podendo ser consideradas como alterações na concentração de uma substância ou organismo, através da velocidade de consumo do substrato, a velocidade de crescimento dos microrganismos e a formação de produtos resultantes de processos físicos, químicos e biológicos (Horan, 1990).

No início da operação de um reator de lodos ativados, há poucos miligramas por litro de biomassa presente na água residuária. Assim, têm-se uma relação A/M alta e as bactérias ainda estão dispersas no meio líquido. Durante o crescimento populacional, a relação A/M muda rapidamente, ocorrendo um aumento dos microrganismos e uma diminuição de alimento disponível. A partir da condição em que se estabelece uma relação A/M baixa, as células começam a formar aglomerados - os flocos de lodos ativados (Horan, 1990).

As exigências dos organismos heterotróficos com relação ao material orgânico que devem retirar do meio são muito variáveis. O mais comum é a ocorrência do heterotrofismo completo, no qual o organismo necessita de uma dieta constituída por açúcares, gorduras, proteínas e sais minerais (Branco, 1986).

Assim, à medida que a matéria orgânica do meio é oxidada pelo metabolismo biológico, é consumido oxigênio pelos organismos e nova massa celular é sintetizada, até um ponto no qual os organismos efetuam auto-oxidação de sua massa celular progressivamente durante o processo de decaimento endógeno (Branco, 1986). 
Para o desenvolvimento e crescimento das bactérias, ocorrem simultaneamente dois processos metabólicos, o primeiro é a degradação da matéria carbonácea pela oxidação, transformando-a em compostos estáveis - processo de catabolismo, possibilitando a geração de energia, usada na síntese celular, como se segue:

$$
\underset{\substack{\text { (material orgânico } \\ \text { e nitrogenado) }}}{\mathrm{CHON}}+\mathrm{O}_{2} \longrightarrow \mathrm{CO}_{2}+\mathrm{H}_{2} \mathrm{O}+\text { energia }+ \text { síntese celular }
$$

Para a síntese celular, são utilizados nutrientes, entre os quais são requeridos em maiores frações os nutrientes carbono, oxigênio, hidrogênio, nitrogênio, fósforo e enxofre.

O segundo processo, anabolismo, é a transformação de pequenas moléculas resultantes da oxidação da matéria carbonácea e incorporação na massa celular, em componentes celulares requeridos para o crescimento de microrganismos, utilizando a energia gerada pela primeira reação. A reação deste processo é assim representada:

$$
\text { Pequenas moléculas }+ \text { energia } \longrightarrow\left(\mathrm{CH}_{2} \mathrm{O}\right)_{n} \mathrm{~N}+\mathrm{H}_{2} \mathrm{O}
$$

Quando há pequena disponibilidade de material orgânico biodegradável no meio, o crescimento dos microrganismos diminui, e muitos microrganismos são forçados a utilizar suas próprias reservas, oxidando seu próprio material celular carbonáceo para prover a energia necessária para o seu metabolismo. Este processo, conhecido como metabolismo endógeno, pode ser assim representado:

$$
\left(\mathrm{CH}_{2} \mathrm{O}\right)_{n} \mathrm{~N}+\mathrm{O}_{2} \longrightarrow \mathrm{CO}_{2}+\mathrm{NH}_{3}+\mathrm{H}_{2} \mathrm{O}+\text { energia }
$$


Assim, a fase endógena está relacionada ao decaimento da concentração da biomassa, quando o substrato exógeno não está disponível. Desta forma, as células perdem suas funções vitais, morrem, ocorre sua ruptura e os materiais celulares que permanecem se tornam disponíveis a outras células vivas do meio (Csuros, 1999; Eckenfelder, 1992; Horan, 1990).

\subsection{Microbiologia de lodos ativados}

Os esgotos provêm condições ideais ao crescimento de uma grande diversidade de microrganismos, os quais tem um papel importante em todos os estágios do tratamento biológico de esgotos. Diante da variedade de compostos orgânicos e inorgânicos disponíveis nos esgotos, um diverso ecossistema se desenvolve no reator, onde há uma complexidade de interações da microfauna, tanto de competição quanto de predação.

A composição desta comunidade no reator depende da competição pela variada e limitada disponibilidade de alimento, sendo também influenciada por parâmetros ambientais, como por exemplo pH e temperatura, entre outros (Eckenfelder, 1992). No lodo de sistemas de lodos ativados, geralmente é encontrada uma grande diversidade de espécies de microrganismos, entre bactérias, protozoários, fungos e micrometazoários. Estes organismos ocorrem em grandes populações, principalmente as bactérias, que estão presentes em quantidades que variam em média entre 1 a $38 \times 10^{6} / \mathrm{ml}$, enquanto que os protozoários ocorrem em aproximadamente cerca de $5 \times 10^{4} / \mathrm{ml}$, representando cerca de $5 \%$ do peso dos sólidos em suspensão do lodo (Horan, 1990; Lester \& Birkett, 1999). 
Os microrganismos do processo de lodos ativados que desempenham o papel mais importante são as bactérias, que constituem os decompositores primários, que degradam substratos complexos. A partir destes organismos decompositores, vive uma microfauna de consumidores primários - os protozoários, sendo também sujeitos à predação entre si. As interações que ocorrem no processo, de competição e de predação, são muito diversificadas (Vazoller, 1989).

Os protozoários e os micrometazoários apresentam importância secundária, exercendo contribuição na redução da turbidez do efluente e na estrutura dos flocos. Já os fungos, que não são muito comumente encontrados na comunidade de lodos ativados, não têm sua função no processo de tratamento conhecida com grandes detalhes, exceto pela sua possível influência na ocorrência do intumescimento filamentoso, quando presentes em quantidades excessivas no lodo. Porém, eles não são tão importantes neste fenômeno quanto as bactérias filamentosas (Lester \& Birkett, 1999).

O exame microscópico do lodo ativado permite determinar as características físicas dos flocos e a abundância relativa de organismos filamentosos. Quanto à microfauna presente, esta pode ser utilizada como indicador biológico, uma vez que representa determinadas condições de funcionamento do processo, através da identificação dos organismos presentes. Como a identificação das bactérias geralmente é um processo mais lento e oneroso, os protozoários são utilizados como indicadores no controle do processo, os quais são submetidos a métodos simples de análise e identificação (Vazoller, 1989). Assim, a análise rotineira da microfauna como indicador do desempenho de sistemas de lodos ativados fornece rápidas informações sobre a atividade biológica do lodo ativado, tendo como base a observação da estrutura da comunidade de microrganismos presentes (Perez, 1995 apud 
Madoni, 1994). Alguns microrganismos presentes em sistemas de lodos ativados, indicativos das características do processo estão apresentados na Tabela 1.

Um fator importante a ser avaliado é a concentração de bactérias filamentosas em relação aos flocos bacterianos, que deve ser limitada para que não ocorram problemas na sedimentação do lodo - fenômeno do intumescimento filamentoso do lodo (Vazoller, 1989).

TABELA 1 - MICRORGANISMOS INDICADORES DAS CONDIÇÕES DE DEPURAÇÃO, SEGUNDO AS CARACTERÍSTICAS DO PROCESSO

MICRORGANISMOS

Predominância de flagelados e rizópodes

Predominância de flagelados

Predominância de ciliados pedunculados e livres

Presença de Arcella (rizópode com teca)

Presença de Aspidisca costata (ciliado livre)

Presença de Trachelophyllum (ciliado livre)

Presença de Vorticella microstoma (ciliado

pedunculado) e baixa concentração de ciliados Efluente de má qualidade livres

Predominância de anelídeos do gênero Aelosoma

Predominância de filamentos

\section{CARACTERÍSTICAS DO PROCESSO}

Lodo jovem, característico de início de operação ou idade do lodo baixa

Deficiência de aeração, má depuração e sobrecarga orgânica

Boas condições de depuração

Boa depuração

Nitrificação

Idade do lodo alta

Excesso de oxigênio dissolvido

Intumescimento do lodo ou bulking filamentoso ${ }^{1}$ 


\subsubsection{Bactérias}

As bactérias são os microrganismos mais importantes do sistema de lodos ativados, sendo responsáveis pela decomposição da matéria orgânica do esgoto e pela formação dos flocos, este último fator permite a separação dos sólidos, e assim, possibilita a sedimentação do lodo na unidade de decantador. A maioria das bactérias presentes em lodos ativados são quimioheterotróficas, oxidando matéria orgânica a dióxido de carbono e água, a partir do consumo de compostos orgânicos, com a utilização do oxigênio molecular como aceptor de elétrons; e gram-negativas (Horan, 1990; Jenkins et al., 2004).

Algumas bactérias presentes neste processo são quimioautotróficas, realizando a síntese orgânica a partir de gás carbônico e água, utilizando com fonte de energia a oxidação aeróbia de compostos inorgânicos formados por nitrogênio, enxofre e ferro, entre outros; dentre elas destacam-se as bactérias responsáveis pela oxidação da amônia em nitrito (gênero Nitrosomonas), nitrito a nitrato (gênero Nitrobacter) e sulfeto de hidrogênio (como Thiothrix) (Berck \& Gundenson, 1993). Estes gêneros de bactérias nitrificantes são encontrados somente em algumas condições específicas, além de outras, como bactérias sulfurosas tais como Beggiatoa e Thiothrix. Bactérias filamentosas como Sphaerotillus, Haliscomenobacter, Microthrix e Nostocoida constituem a maioria dos membros heterotróficos da comunidade do lodo (Eckenfelder, 1992).

No processo de lodos ativados, as bactérias constituem o maior componente da comunidade microbiana, sendo freqüentemente encontradas cerca de mais de $10^{6}$ bactérias por $\mathrm{ml}$ de esgoto, e pode haver várias espécies de bactérias compondo a comunidade do floco (Horan, 1990). Os gêneros de bactérias comumente encontrados em lodos ativados estão apresentados na Tabela 2 (Lester \& Birkett, 1999). 


\begin{tabular}{ll}
$\begin{array}{l}\text { TABELA } 2 \text { - GÊNEROS DE BACTÉRIAS COMUMENTE ENCONTRADOS EM } \\
\text { LODOS ATIVADOS }\end{array}$ \\
\hline PRINCIPAIS GÊNEROS & OUTROS GÊNEROS \\
\hline Zooglea & Aeromonas \\
Pseudomonas & Aerobacter \\
Comomonas & Micrococcus \\
Flavobacterium & Spirillum \\
Alcaligenes & Acinetobacter \\
Brevibacterium & Gluconobacter \\
Bacillus & Cytophaga \\
Achromobacter & Hyphomicrobium \\
Corynebacterium & \\
Sphaerotillus & \\
Arthrobacter & \\
Citromonas & \\
Chromobacterium & \\
Flexibacter & \\
\hline
\end{tabular}

FONTE: LESTER, J.N.; BIRKETT, J.W. Microbiology and chemistry for environmental scientists and engineers. London: E\&FN Spon, 1999.

Segundo Horan (1990), a influência dos principais gêneros de bactérias em sistemas de lodos ativados, através de suas reações, estão descritos na Tabela 3. 
TABELA 3 - REAÇÕES PROMOVIDAS PELOS PRINCIPAIS GÊNEROS DE BACTÉRIAS ENCONTRADAS EM LODOS ATIVADOS

\begin{tabular}{ll}
\hline \multicolumn{1}{c}{ GÊNEROS } & \multicolumn{1}{c}{ FUNÇÕES } \\
\hline Pseudomonas & Remoção de substrato, produção de muco, desnitrificação \\
Zoogloea & Produção de muco, formação do floco \\
Bacillus & Degradação de proteínas \\
Athrobacter & Degradação de carboidratos \\
Microthrix & Degradação de gordura, crescimento filamentoso \\
Nocardia & Crescimento filamentoso, formação de espuma e escuma \\
Acinetobacter & Remoção de fósforo \\
Nitrosomonas & Nitrificação \\
Nitrobacter & Nitrificação \\
Achromobacter & Desnitrificação \\
\hline
\end{tabular}

FONTE: HORAN, N.J. Biological wastewater treatment systems: theory and operation. Chichester; New York: Willey, 1990.

\subsubsection{Protozoários}

Em lodos ativados, os protozoários podem ocorrer em grande diversidade e em abundância, sendo observados os grupos de protozoários: flagelados, amebas, ciliados livrenatantes e ciliados pedunculados (Jenkins et al, 2004). Segundo Berk e Gunderson (1993), aproximadamente 5\% da biomassa de sistemas de lodos ativados é constituída por protozoários e metazoários, o que representa cerca de 50.000 organismos $/ \mathrm{ml}$. Dentre estes, o principal grupo de protozoários encontrados em lodos ativados é o de ciliados. 
Os protozoários são organismos eucarióticos que demonstram uma grande diversidade de formas e modos de vida. Sendo geralmente unicelulares, muitos são de vida livre, enquanto outros são sésseis, sendo alguns destes formadores de colônias (Horan, 1990).

O papel primário dos protozoários em lodos ativados é clarificar o efluente, reduzindo sua turbidez através da predação de outros organismos, principalmente bactérias, além de matéria orgânica particulada, atuando no polimento dos efluentes dos processos biológicos de tratamento de águas residuárias (Metcalf \& Eddy, 1991). Este é o modo de nutrição mais praticado entre a grande variedade de estratégias alimentares utilizadas pelos protozoários. A maioria das espécies alimenta-se de bactérias, enquanto algumas predam outros protozoários ciliados, e outras espécies alimentam-se de flagelados. Além destas, há também algumas espécies de protozoários que alimentam-se de algas (Horan, 1990).

Os protozoários desempenham outra importante função num reator biológico - ao capturar bactérias pela predação, removem bactérias senescentes e mantêm a população destas num estado fisiológico jovem, possibilitando uma taxa de assimilação de matéria orgânica maior pelas bactérias, e desta forma, eles selecionam, até certo ponto, as espécies bacterianas formadoras de flocos (Berk \& Gunderson, 1993). Inclusive, é provável que os protozoários também podem contribuir com a integridade e formação dos flocos, sendo resultante da secreção de uma proteína mucosa de material polissacarídeo, que pode ser produzido e secretado por muitas espécies de protozoários presentes, e que pode ter a mesma função do polímero extracelular produzido por bactérias (Lester \& Birkett, 1999).

A predação efetuada por protozoários é freqüentemente aceita como sendo a responsável pela elevada remoção de patógenos do processo de lodos ativados, sendo que a 
remoção de coliformes e de vírus ocorre freqüentemente acima de 90\% (Lester \& Birkett, 1999).

A importante atuação dos protozoários em sistemas de tratamento de lodos ativados foi estudada por Curds \& Hawkes (1983), que examinaram parâmetros de qualidade do efluente através de simulações em plantas de lodos ativados em escala de laboratório, relacionando estes parâmetros à presença e ausência de protozoários ciliados. Os autores verificaram que a presença de protozoários ocasiona a redução de sólidos em suspensão e de DBO solúvel do efluente, uma vez que os protozoários são também capazes de utilizar substratos orgânicos dissolvidos.

Centenas de espécies de protozoários podem estar presentes em lodos ativados. Segundo a classificação taxonômica, os grupos de protozoários (Filo Protozoa) encontrados em lodos ativados são: Classe Mastigophora: flagelados; Classe Sarcodina: amebas e tecamebas; e Classe Ciliata: ciliados livres, fixos e ratejantes. Entre estas classes, os mais freqüentes são os ciliados, embora números significativos de amebas e flagelados podem se desenvolver sob certas condições. Os gêneros de protozoários freqüentemente encontrados em sistemas de lodos ativados são Paramecium, Vorticella, Aspidisca, Bodo e Amoeba, entre outros (Vazoller, 1989).

Os grupos de protozoários desenvolvem-se no processo de lodos ativados de acordo com as características do meio, que variam conforme as características operacionais da estação de tratamento. Assim, a caracterização da comunidade de protozoários presentes no tanque de aeração do sistema é uma ferramenta útil para o monitoramento do tratamento biológico, uma vez que a estrutura da comunidade de protozoários reflete a qualidade do efluente (Nicolau et al., 2001). Por exemplo, a presença de ciliados é geralmente considerada 
indicativa de um bom processo de tratamento. Porém, é importante mencionar que o afluente pode derivar de muitas fontes diferentes e inclusive conter substâncias diferentes ou compostos tóxicos, e os protozoários, além de outros organismos, podem adaptar-se à composição química do efluente, resultando em diferentes estruturas da comunidade dependendo da composição do afluente (Berk \& Gunderson, 1993).

Algumas relações entre os protozoários dominantes em sistemas de lodos ativados, indicativos do desempenho do processo de tratamento de esgotos sanitários, e as possíveis características operacionais que favorecem o crescimento destes organismos, estão apresentadas na Tabela 4.

TABELA 4 - RELAÇÃO ENTRE O DESEMPENHO DO SISTEMA DE LODOS ATIVADOS E A PRESENÇA DE GRUPOS DE PROTOZOÁRIOS DOMINANTES NA MICROFAUNA

\begin{tabular}{|c|c|c|}
\hline GRUPO DOMINANTE & DESEMPENHO & POSSÍVEIS CAUSAS \\
\hline Pequenos flagelados & Fraco & $\begin{array}{l}\text { Deficiência de aeração, choques devido à sobrecarga } \\
\text { e presença de subprodutos da fermentação }\end{array}$ \\
\hline Pequenos ciliados livres natantes & Médio & $\begin{array}{l}\text { Deficiência de aeração, baixo tempo de detenção } \\
\text { hidráulico }\end{array}$ \\
\hline Grandes ciliados livres natantes & Médio & $\begin{array}{l}\text { Choques devido à sobrecarga e deficiência de } \\
\text { aeração }\end{array}$ \\
\hline Ciliados livres predadores de flocos & Bom & - \\
\hline $\begin{array}{l}\text { Ciliados pedunculados e livres } \\
\text { predadores de flocos }\end{array}$ & Bom & - \\
\hline Ciliados pedunculados & Decaindo & Alimentação irregular e perda de lodo recente \\
\hline Pequenas amebas & Muito fraco & Alta carga de compostos de difícil degradação \\
\hline Arcella (ameba) & Bom & - \\
\hline
\end{tabular}

FONTE: MADONI, P. A sludge biotic index (SBI) for the evaluation of the biological performance of activated sludge plants based on the microfauna analysis. Water Research. Vol. 28, № 1, pp. 67-75, 1994.

O principais grupos de protozoários encontrados em lodos ativados, suas características e as condições ambientais em que ocorrem estão descritos a seguir. 


\section{- Flagelados}

São protozoários caracterizados por apresentar um ou mais flagelos como estrutura de locomoção, sendo filamentos alongados que executam movimentos ondulatórios. São organismos pequenos, apresentando tamanho entre 5 a $20 \mu \mathrm{m}$, com morfologia oval ou alongada. Muitas espécies encontradas em lodos ativados alimentam-se de matéria orgânica solúvel e a sua predominância pode indicar níveis elevados de matéria orgânica solúvel. Muitos destes organismos ocorrem em baixos níveis de oxigênio dissolvido e alta carga orgânica (Bitton, 1999).

\section{- Rizópodes ou Amebas}

As amebas são organismos unicelulares que possuem membrana celular flexível, permitindo formas variadas da célula, sendo assim, variam muito em morfologia e tamanho, havendo espécies que apresentam entre 10 a $200 \mu \mathrm{m}$, que locomovem-se através de pseudópodes (“falsos pés”), que são organelas constituídas por prolongamentos protoplasmáticos, que se formam em quaisquer pontos da célula. Algumas espécies possuem uma carapaça, como por exemplo, a espécie de ameba Arcella, comumente encontrada em lodos ativados. As amebas crescem bem em matéria orgânica particulada e são capazes de tolerar baixas concentrações de oxigênio dissolvido ambientais. Uma florescência de amebas pode indicar uma elevada quantidade de matéria orgânica no efluente (Jenkins et al., 2004).

Com relação à nutrição, a maioria das espécies de amebas é carnívora, alimentando-se principalmente de ciliados e flagelados, enquanto algumas alimentam-se de algas, e outras são onívoras. As amebas menores alimentam-se principalmente de bactérias e partículas em suspensão, formando vacúolo em volta destes, cuja porção orgânica destas partículas pode ser 
utilizada após digestão enzimática dentro do vacúolo (Berk \& Gunderson, 1993; Horan, 1990).

\section{- Ciliados}

Os protozoários ciliados são caracterizados pela presença de cílios na superfície de sua célula e podem ser livre-natantes ou fixos (pedunculados). Alguns ciliados são cobertos por cílios em toda sua superfície, enquanto que algumas espécies apresentam-se apenas parcialmente cobertos, e ainda algumas espécies apresentam cílios apenas em determinada fase de suas vidas (Eikeboom, 2000). A predominância de ciliados livres e pedunculados indica boas condições de depuração do sistema, operação estável e formação de flocos com boas características de sedimentabilidade (Vazoller, 1989; Jenkins et al, 1993). Os grupos de ciliados encontrados em sistemas de lodos ativados estão descritos a seguir.

\section{- Ciliados livre-natantes}

Apresentam forma arredondada ou oval, com tamanhos que variam entre 20 a $400 \mu \mathrm{m}$, sendo ativamente móveis por fileiras de pequenos cílios localizados em toda a superfície celular externa, os quais, através de batimentos permitem a locomoção do organismo. Em algumas espécies os cílios se apresentam localizados em pontos do corpo que lhes possibilitam rastejar sobre os flocos de lodos ativados. Estes tipos de ciliados são geralmente encontrados em condições de boa formação dos flocos e geralmente indicam uma operação satisfatória do processo de lodos ativados. Os ciliados livre-natantes são sensíveis às condições ambientais, e por isso a ausência destes pode indicar toxicidade (Jenkins et al, 2004; Horan, 1990). 


\section{- Ciliados pedunculados:}

Os ciliados pedunculados, tais como os livre-natantes, também apresentam cílios como estrutura locomotora, no entanto, estes apresentam um pedúnculo contrátil ou rígido, que permite a sua fixação em substrato sólido e o agrupamento destes organismos em colônias. Em sistemas de lodos ativados, a maioria dos ciliados pedunculados vive fixa na superfície dos flocos, sendo algumas espécies apresentando um organismo por pedúnculo (como por exemplo Vorticella spp), enquanto há outras que são coloniais (como Epistylis spp e Opercularia spp) (Jenkins et al., 2004). Os protozoários deste grupo alimentam-se de bactérias livres em suspensão (Horan, 1990).

Os ciliados pedunculados ocorrem em condições ambientais similares às que propiciam o aparecimento de ciliados livre-natantes, geralmente com baixa carga orgânica (alta idade do lodo). As espécies individuais (não coloniais) podem ser utilizadas como indicativas da idade do lodo, e as formas coloniais indicam alta idade do lodo, com mais indivíduos por colônia, assim que a idade do lodo aumenta (Bitton, 1999). 


\subsubsection{Micrometazoários}

Os micrometazoários (rotíferos, nematóides e anelídeos) são microrganismos pluricelulares heterótrofos estritamente aeróbios, que alimentam-se de matéria orgânica particulada, bactérias mortas, protozoários e fragmentos de flocos. Entre os micrometazoários, os mais freqüentes e de maior interesse no processo de tratamento de esgotos de lodos ativados são os rotíferos. Os metazoários parecem ocorrer em sistemas de lodos ativados somente com nitrificação, provavelmente devido à sua suscetibilidade à toxicidade por amônia (Jenkins et al., 2004).

\section{- Rotíferos}

Os rotíferos apresentam estruturas mais complexas que os protozoários, e uma variedade de formas e de tamanhos (entre 50 a $250 \mu \mathrm{m}$ ). Apresentam corpo alongado ou sacular relativamente cilíndrico, sendo em muitas espécies dividido em uma região anterior curta, um grande tronco que constitui a maior parte do corpo e uma porção terminal do corpo ou pé, dotado de uma a quatro projeções, dependendo da espécie, sendo utilizadas para fixação ao substrato. O corpo destes organismos geralmente é transparente, embora alguns rotíferos pareçam verdes, alaranjados, vermelhos ou marrons, devido à coloração do trato digestivo (Barnes \& Ruppert, 1996).

Todos os membros do filo Rotifera apresentam na extremidade anterior do corpo um órgão ciliado circundando a boca, chamado de coroa, que é um anel de cílios utilizado na alimentação, através dos quais seu movimento de vibração possibilita a captura de bactérias e de outros organismos, e partículas orgânicas em suspensão para o consumo. Os hábitos 
alimentares dos rotíferos têm papel fundamental na densidade desses organismos em sistemas de lodos ativados, lagoas de estabilização e filtros biológicos. As espécies predadoras são onívoras, alimentando-se também de partículas orgânicas em suspensão, enquanto que há espécies que alimentam-se de protozoários, pequenos organismos metazoários e outros rotíferos. Em processos de lodos ativados, estes organismos desempenham um papel similar ao dos protozoários, contribuindo para a clarificação do efluente ao consumir bactérias livrenatantes e partículas em suspensão (Barnes et al., 1988; Barnes \& Ruppert, 1996; Lester \& Birkett, 1999).

A maioria dos rotíferos é livre-natante ou rastejante, havendo também muitas espécies sésseis, associados com o substrato sólido, assim como algumas espécies coloniais (Barnes \& Ruppert, 1996). A maioria dos rotíferos encontrados em lodos ativados são móveis, podendo fixar-se aos flocos através dos pés contráteis (Lester \& Birkett, 1999).

Em reatores biológicos, os rotíferos tem papel no topo da cadeia trófica, cuja presença destes geralmente é considerada desejável (Lester \& Birkett, 1999), indicando uma boa eficiência do processo de depuração biológica, uma vez que os rotíferos são muito eficientes no consumo de bactérias dispersas ou aderidas a flocos, e pequenas partículas de matéria orgânica, e a presença de rotíferos em sistemas de lodo ativado indica a depuração de 90 a 95\% do afluente (Metcalf \& Eddy, 1991). Além disso, os rotíferos contribuem no controle populacional de protozoários, e em processo de lodos ativados a relação volumétrica entre rotíferos, ciliados e rizópodes é de 1:4:5 (Doohan, 1975 apud Damato, 1999).

Os gêneros do filo Rotifera associados ao tratamento de esgotos são Philodina e Rotaria, sendo mais comumente encontrados os do gênero Lecane. Em lodos ativados, os 
rotíferos geralmente ocorrem a partir de determinada idade do lodo, sendo algumas espécies indicativas de alta idade do lodo (Jenkins et al., 2004).

\section{- Nematodos}

Os nematodos são organismos alongados, aeróbios e heterotróficos, que apresentam corpo cilíndrico, delgado e alongado, não sendo segmentados ao longo do corpo, com ambas as extremidades gradualmente afiladas, na maioria das espécies. Apresentam geralmente comprimento entre 0,5 a $3 \mathrm{~mm}$, que corresponde a cerca de duas vezes o tamanho médio dos rotíferos (Barnes, 1996).

Muitas espécies aquáticas de nematodos são carnívoras e alimentam-se de bactérias, algas e fungos, enquanto que algumas espécies consomem organismos metazoários pequenos, incluindo outros nematodos. Constituem o maior e mais comum grupo de organismos que se alimentam de fungos e de bactérias, tendo grande importância nas cadeias alimentares lideradas pelos decompositores (Barnes, 1996).

Os nematodos constituem o mais abundante grupo de metazoários em filtros biológicos, porém, em lodos ativados estes organismos são raramente encontrados, podendo ocorrer em sistemas com baixa carga orgânica e com alta idade do lodo (Jenkins et al, 2004). Os representantes deste filo que ocorrem neste processo pertencem ao gênero Rhabditis. Apesar da possibilidade destes organismos serem encontrados em processos de lodos ativados, a sua contribuição à eficiência do processo é mínima (Lester \& Birkett, 1999), e segundo Eikelboom (2000) apud Mendonça (2002), não se tem conhecimento se esses metazoários podem ser utilizados como indicadores das condições do processo. 


\section{- Anelídeos}

Os anelídeos são organismos vermiformes alongados, aeróbios, heterotróficos e pluricelulares. Apresentam simetria bilateral e divisão do corpo em segmentos, arranjados em série linear em toda sua extensão.

Os anelídeos habitam ambientes terrestres e aquáticos. Destes últimos, a maioria habita as águas doces, além dos ambientes marinhos, sendo também encontrados em reatores das estações de tratamento de esgotos. As espécies de anelídeos que habitam todos os tipos de ambientes aquáticos são membros da classe Oligochaeta, cuja ocorrência em abundância de espécies diferentes de oligoquetas aquáticos nas águas naturais pode ser uma condição indicativa de poluição, uma vez que a maioria das espécies de oligoquetas alimenta-se de matéria orgânica e de pequenos detritos (Barnes, 1996).

Os membros do filo Anelida não são muito comuns em sistemas de lodos ativados, e quando ocorrem em grandes quantidades indica a condição de excesso de oxigênio dissolvido no reator (Vazoller, 1989), sendo os indivíduos geralmente pertencentes ao gênero Aeolosoma, que alimentam-se de sólidos em suspensão, microrganismos e algas (Branco, 1986; Lester \& Birkett, 1999). 


\section{- Tardígrados}

Os tardígrados, conhecidos com ursos d'água, são curtos e possuem quatro pares de pernas ventrais, sendo todas terminando com garras. Apresentam geralmente tamanho entre 0,3 a 0,5 $\mathrm{mm}$, sendo que algumas espécies atingem até $1,2 \mathrm{~mm}$ de comprimento (Barnes, 1996).

A maioria dos tardígrados alimenta-se de detritos orgânicos e de algas, além de nematodos, rotíferos e de outros tardígrados, os quais são perfurados com um aparelho semelhante a um estilete, projetado para puncionar a parede celular, para que o conteúdo do organismo seja sugado diretamente pela faringe. Habitam ambientes aquáticos, havendo espécies marinhas com ampla distribuição, tanto em águas raras como profundas; de água doce, que vivem nos detritos do fundo ou nas algas; e semi-aquáticas, como em filmes de água no solo, em resíduos de vegetação e em folhas de musgos e líquens terrestres. As formas semi-aquáticas podem sobreviver por longos períodos num estado "desidratado" e retornam à vida ativa quando a água volta a estar disponível (Webb et al., 1985; Barnes, 1996). A presença de tardígrados no processo de lodos ativados é pouco comum, desta forma, o seu papel como indicador das condições de depuração é desconhecido (Figueiredo, 1995). 


\subsubsection{Fungos}

Os fungos não são muito freqüentes em sistemas de lodos ativados bem operados, sendo normalmente favorecidos por determinadas condições do meio, como lodo com pH baixo (menor que 6), ou na ocorrência de acentuada queda de $\mathrm{pH}$; despejo rico em carboidratos; e deficiência de nutrientes, especialmente nitrogênio e fósforo (Jenkins et al., 1993; Figueiredo, 1995). Sob estas condições, caso ocorram em quantidade excessiva, e sendo os organismos relativamente predominantes sobre os demais, podem causar intumescimento do lodo, prejudicando a sedimentação. No entanto, eles não são tão importantes neste fenômeno quanto as bactérias filamentosas (Lester \& Birkett, 1999), como anteriormente observado.

Geralmente os fungos ocorrem dentro dos flocos, apresentando filamentos longos com ramificação, com largura entre 5,0 a $10 \mu \mathrm{m}$ e 100 a $1000 \mu \mathrm{m}$ de comprimento. Apresentam ausência de bainha, não apresentam motilidade e não ocorre crescimento atado de bactérias nos fungos que estão ligados aos flocos.

Entre os fungos comumente encontrados em lodos ativados, destaca-se o gênero Geotrichum (Vazoller, 1989), entre outros como Fusarium, Geotrichoides Oospora, Phoma, Pullularia, Sporotrichum, Zoophagus, Arthrobotrys (Além Sobrinho, 1998). 


\subsection{O floco de lodos ativados}

Os flocos de lodos ativados consistem em aglomerados de microrganismos com composição altamente heterogênea, sendo formados por dois tipos de componentes: biológico, constituído por uma grande variedade de bactérias, protozoários, fungos e alguns micrometazoários; e um componente não biológico composto por grande quantidade de materiais particulados e coloidais orgânicos e inorgânicos, todos juntos numa matriz orgânica compacta (Jenkins et al., 1993).

Baseando-se nas características físicas, há dois níveis de estrutura no floco de lodos ativados - microestrutura e macroestrutura. A macroestrutura é formada por bactérias filamentosas, sendo considerada como o "esqueleto" do floco, atuando na construção deste, enquanto que a microestrutura é a base do floco, que forma os agregados de células (Lester \& Birkett, 1999).

Os flocos apresentam características claramente observáveis que os diferenciam, tais como morfologia, estrutura, tamanho, composição dos flocos, presença ou ausência de partículas orgânicas ou inorgânicas no floco, microrganismos filamentosos e crescimento disperso de bactérias livres entre os flocos. A aparência morfológica dos flocos dependem da estrutura das populações microbianas e das condições nutricionais do meio. Muitos microrganismos têm tendência de se aderirem uns às interfaces dos outros, sendo que sob determinadas condições eles aparecem livres e dispersos, e sob outras formam agregados. Essa agregação é influenciada pela distribuição espacial e temporal dos nutrientes. Com relação ao aspecto de coloração, os flocos podem apresentar cor que pode variar de amarelo- 
verde a marrom-preto, devido aos componentes presentes nos mesmos (Eikelboom \& Buijsen, 1981).

O mecanismo de formação dos flocos é complexo, sendo o resultado de interações físico-químicas e biológicas, em que muitos fatores estão envolvidos, entre os quais um dos principais é a produção e função de polímeros microbianos extracelulares, atuando como polieletrólitos. Estes consistem em vários tipos de polissacarídeos e glicoproteínas, que envolvem células individuais ou grupos de células (Jenkins et al., 1993).

Acredita-se que a matriz polimérica extracelular age parcialmente como um material viscoso que pode envolver fisicamente as células, que aderem-se nele, incluindo nestes os organismos que são incapazes de flocular entre si (Lester \& Birkett, 1999). Segundo Aisse (1985), além da ação desta matriz bacteriana gelatinosa, outros fatores podem interferir na biofloculação, como características superficiais e coloidais, baixo nível energético e aglomeração de protozoários, sendo provável que ocorra uma combinação destes mecanismos durante este fenômeno.

Segundo Figueiredo (1995), a habilidade dos microrganismos de flocularem em tanques de aeração ocorre em função do nível de energia do sistema. Este autor observou que no material floculado as bactérias se apresentam imóveis, com o metabolismo reduzido ao mínimo; e que o mecanismo de floculação não ocorre quando as bactérias se encontram em fase logarítmica de crescimento, sendo apenas floculadas as bactérias em fase endógena, ou seja, uma baixa taxa de crescimento específico possivelmente favorece a floculação. Desta forma, um dos fatores que afeta a floculação é a capacidade é a capacidade energética do meio em que vivem, além de outros fatores físico-químicos, como a taxa de crescimento, composição da população, concentração de substrato e de nutriente. 
Os flocos de lodos ativados, por meio dos microrganismos presentes nestes, têm um papel essencial no processo de remoção de matéria orgânica. Acima de $40 \%$ da matéria orgânica do efluente, solúvel ou insolúvel, é rapidamente absorvida pela matriz do floco por interações iônicas. No floco, a matéria orgânica é acessível através hidrólise por meio de enzimas extracelulares, antes de serem absorvidas e metabolizadas pelas bactérias do floco. Em flocos com diâmetro entre 50 a $500 \mu \mathrm{m}$, há um decrescente gradiente de concentração de matéria orgânica e de oxigênio, do exterior do floco ao centro deste. Conseqüentemente, as bactérias do centro do floco poderão ser desprovidas de uma fonte de nutrientes e de oxigênio.

Além de promover a remoção de matéria orgânica do efluente, outra influência importante dos flocos de lodos ativados é no tocante à sedimentação do lodo no decantador secundário, determinada pelas características morfológicas dos flocos, sendo que a sedimentação do lodo interfere diretamente na qualidade do efluente (Eikelboom \& Buijsen, 1981). Portanto, a eficiência do tratamento de águas residuárias pelo processo de lodos ativados depende fundamentalmente do fenômeno de floculação biológica e da fase subseqüente de separação dos flocos do efluente tratado.

Os fatores que influenciam o tamanho e a estrutura dos flocos de sistemas de lodos ativado, segundo Jiwani et al. (1997) são:

- idade do lodo: quanto mais elevada é a idade do lodo, maiores e mais compactos serão os flocos;

- concentração de nutrientes: esgoto rico em nitrogênio apresenta flocos mais compactos; 
- mistura no tanque de aeração: elevada intensidade de mistura causa danos aos flocos, resultando em sedimentação ruim;

- concentração de oxigênio dissolvido: em baixas concentrações, acarreta a proliferação de microrganismos filamentosos e, conseqüentemente, implica em lodo com características ruins para a sedimentação;

- tempo de detenção hidráulica (TDH): quanto maior o TDH, melhores são as características dos flocos.

Através de monitoramento microscópico dos flocos presentes no lodo, é possível avaliar a qualidade do lodo, através das características dos flocos, como a estrutura, forma, consistência e tamanho dos mesmos. Dentre estes aspectos, são preferíveis flocos compactos e robustos, pois sedimentam mais rapidamente, e conseqüentemente, conferem melhor qualidade ao efluente final (Eikelboom, 2000 apud Mendonça, 2002).

Desta forma, a avaliação das características dos flocos através de exame microscópico do lodo é indispensável para possibilitar um diagnóstico da performance do processo de tratamento, uma vez que as características morfológicas dos flocos são afetadas pelas condições de operação do sistema de lodos ativados. Através da adoção de monitoramento microscópico dos flocos, é possível a determinação de problemas e assim permitir a otimização da qualidade do efluente final, uma vez que o desempenho de uma estação de tratamento é determinado especialmente pelas características dos flocos, além da qualidade da biomassa no sistema (Eikelboom \& Buijsen, 1981).

Os critérios utilizados para a avaliação da qualidade do lodo no reator, baseado nas características dos flocos estão apresentados na Tabela 5, e a avaliação da qualidade dos 
flocos realizada juntamente com a quantidade de microrganismos estão apresentados nas Tabela 6.

TABELA 5 - RELAÇÃO ENTRE OS TAMANHOS DOS FLOCOS E AS CARACTERÍSTICAS DO LODO

\begin{tabular}{lll}
\hline $\begin{array}{c}\text { TAMANHO DOS } \\
\text { FlOCOS }\end{array}$ & DIÂMETRO & \multicolumn{1}{c}{ CARACTERÍSTICAS DO LODO } \\
\hline Pequenos & $<50 \mu \mathrm{m}$ & Lodo disperso (pint-point) \\
Médios a Grandes & $>100 \mathrm{a} 300 \mu \mathrm{m}$ & Lodo em boas condições \\
Pequenos a Médios & $<100 \mu \mathrm{m}$ & Muito provável intumescimento do lodo \\
Grandes & $>150 \mu \mathrm{m}$ & Intumescimento do lodo \\
\hline
\end{tabular}

FONTE: Adaptado de Vazoller (1989)

TABELA 6 - CRITÉRIOS DE AVALIAÇÃO MICROSCÓPICA PARA DEFINIÇÃO DA QUALIDADE DO LODO

\begin{tabular}{lccc}
\hline \multirow{2}{*}{ CRITÉRIO } & \multicolumn{3}{c}{ QUALIDADE DO LODO } \\
\cline { 2 - 4 } & Boa & Moderada & Pobre \\
\hline Estrutura do floco & Compacto & Aberto & - \\
Consistência do floco & Robusto / firme & Fraco & - \\
Forma do floco & Arredondado & Irregular & $<50$ \\
$\%$ flocos $>25 \mu \mathrm{m}$ & $>80-90$ & $>50-70$ & $\geq 3$ \\
Flagelados / amebas & 0 & $1-2$ & 0 \\
Ciliados / tecamebas & $\geq 2$ & 1 & $\geq 3$ \\
Células livres & $0-1$ & $2-3$ & 4 \\
Filamentos & $<2$ & $2-3$ & 4 \\
\hline
\end{tabular}

NOTA: Escala qualitativa de freqüência: (0) nenhuma; (1) rara; (2) comum; (3) muito comum; (4) abundante.

FONTE: EIKELBOOM, D.H. Process control of activated sludge plants by microscopic investigation. Manual, Assis / IWA, Londes: 2000.

A partir das observações dos critérios de avaliação citados, é possível determinar a qualidade geral do lodo do reator de lodos ativados, considerando que o lodo apresenta uma qualidade boa se no mínimo um critério for moderado e os restantes forem bons (Eikelboom \& Buijsen, 1981). 


\subsection{Bactérias filamentosas e o fenômeno de intumescimento}

As bactérias filamentosas, presentes tanto na estrutura dos flocos como livres, dispersas no meio líquido, além de degradar matéria orgânica, apresentam importância na comunidade de lodos ativados baseada nos aspectos:

- Os microrganismos filamentosos formam a base da estrutura dos flocos de lodos ativados, onde as bactérias formadoras destes são fixadas por meio de polímeros extracelulares;

- A ocorrência excessiva de microrganismos filamentosos na comunidade do lodo causa deterioração na propriedade de sedimentação de lodos ativados;

- A ocorrência do aumento de microrganismos filamentosos na comunidade de lodos ativados indica que o sistema não está projetado ou sendo operado adequadamente (Eckenfelder, 1992).

Cerca de trinta espécies de microrganismos filamentosos são importantes em sistemas de lodos ativados e a presença e quantidade de determinadas espécies de filamentosas pode indicar problemas operacionais específicos no sistema. No entanto, o crescimento das bactérias filamentosas deve ser controlado, pois se ocorrer crescimento de forma excessiva, pode haver a ocorrência de bulking ou intumescimento filamentoso do lodo (Jenkins et al., 1993), que ocorre em condições específicas em que na competição pelo substrato as filamentosas dominam sobre as bactérias formadoras de flocos, apresentando maior crescimento populacional (Bitton, 1999). A abundância de organismos filamentosos, que constituem o intumescimento, ocasiona uma série de problemas operacionais, como interferência na sedimentação e compactação do lodo, devido à formação de estrutura difusa 
dos flocos (não compactos), e pela construção de uma "malha" entre eles, formando-se entre os flocos; e a conseqüente má qualidade do efluente final, uma vez que grandes quantidades de lodo podem ser perdidas neste devido à má sedimentação dos flocos no decantador secundário. Esta perda de lodo pode ainda acarretar a redução de sólidos em suspensão do lodo no reator, devido à baixa concentração de sólidos no fundo do decantador secundário que retornaria ao reator (Jenkins et al., 1993; Lester \& Birkett, 1999).

Algumas das prováveis condições que podem causar o intumescimento são baixo oxigênio dissolvido, baixa proporção A/M, aumento da concentração de sulfeto, deficiência dos nutrientes nitrogênio e fósforo, altas concentrações de matéria orgânica facilmente biodegradável e pH baixo (Jenkins et al., 1993).

A quantificação da ocorrência de microrganismos filamentosos em comunidade de lodos ativados é necessária para se determinar a intensidade dos problemas do intumescimento filamentoso, sendo necessário combinar os dados quantitativos com a identificação das bactérias filamentosas, uma vez que os microrganismos filamentosos causam problemas de intumescimento em diferentes intensidades (Eckenfelder, 1992). Desta forma, um exame microscópico do lodo ativado fornece informações que possibilitam estimar as causas do crescimento excessivo de microrganismos filamentosos, como características e composição do esgoto, configuração do tanque de aeração e outros parâmetros operacionais básicos relacionados. Além disso, as informações obtidas através do exame microscópico do lodo permite determinar o emprego de medidas contra o crescimento excessivo destas bactérias.

Quanto à identificação das bactérias filamentosas, segundo Jenkins et al. (1993) este procedimento têm importância devido a possibilidade de: 
- Verificar se o problema de sedimentação ou formação de escuma é devido ao crescimento excessivo de organismos filamentosos;

- Comparar os organismos filamentosos causadores de intumescimento entre diversas ocorrências para verificar se são os mesmos ou se são diferentes microrganismos;

- Avaliar o efeito de mudanças operacionais com o tipo e abundância dos filamentos presentes.

A maioria das bactérias filamentosas (células) apresentam em média tamanho entre 0,2 a 1,5 $\mu \mathrm{m}$, e sua identificação requer a utilização de microscópio óptico com contraste de fase ou o emprego de técnicas de coloração de lâminas, para possibilitar a visualização das estruturas e características das bactérias sob o microscópio (Horan, 1990). A partir das observação destas características morfológicas, é utilizado o quadro com resumo destas ligadas aos testes de coloração de organismos filamentosos em lodos ativados, e a sua chave para identificação, ambos elaborados por Jenkins et al. (1993), apresentados nas Figuras 3 e 4. Esta chave é constituída pelos 22 organismos filamentosos mais comumente observados em lodos ativados. Durante o trabalho de identificação, se fosse observado determinado organismo que não estivesse descrito nesta chave, este seria classificado como não identificado. 


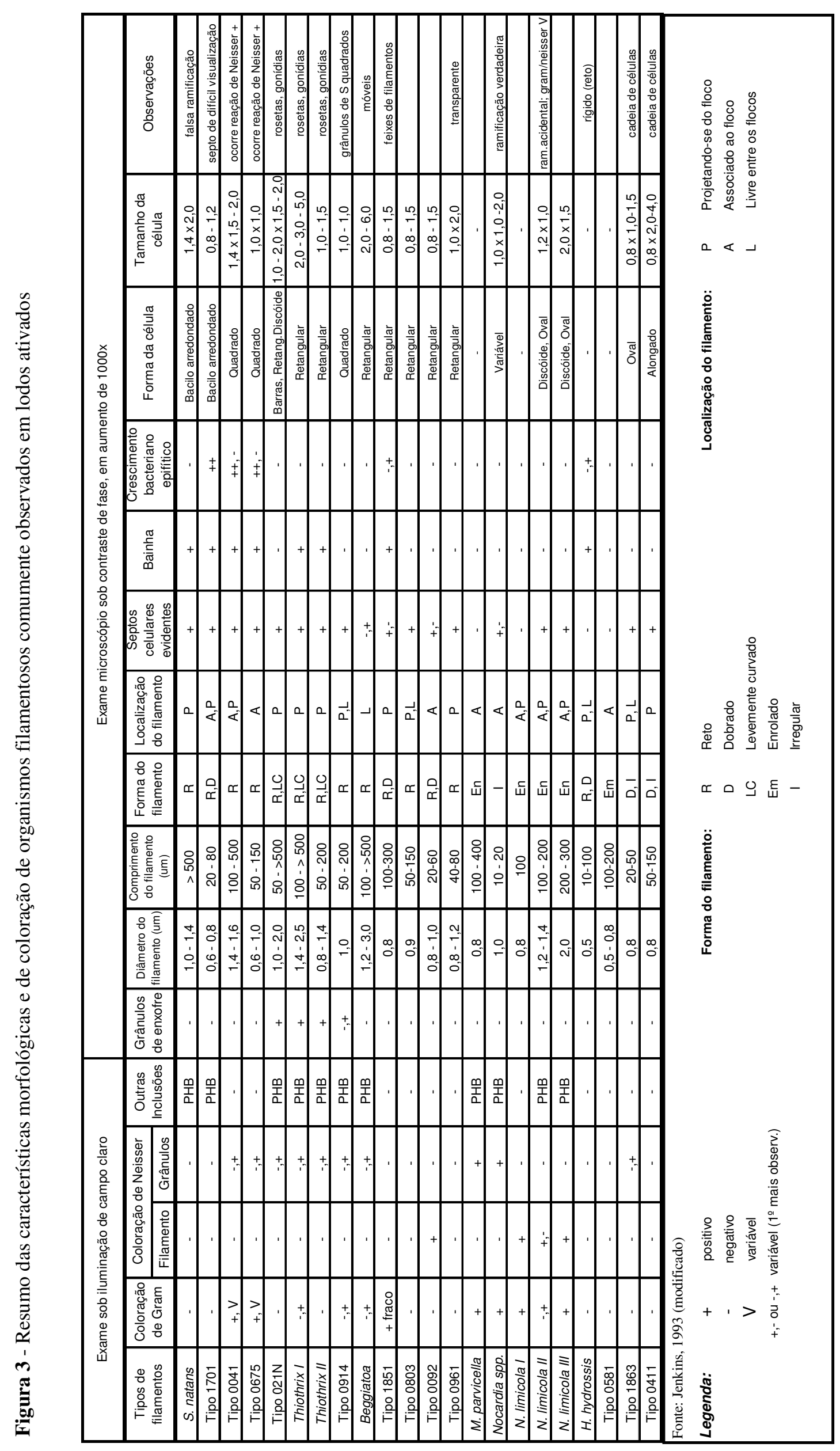


Figura 4 - Chave dicotômica para identificação de organismos filamentosos em lodos ativados.

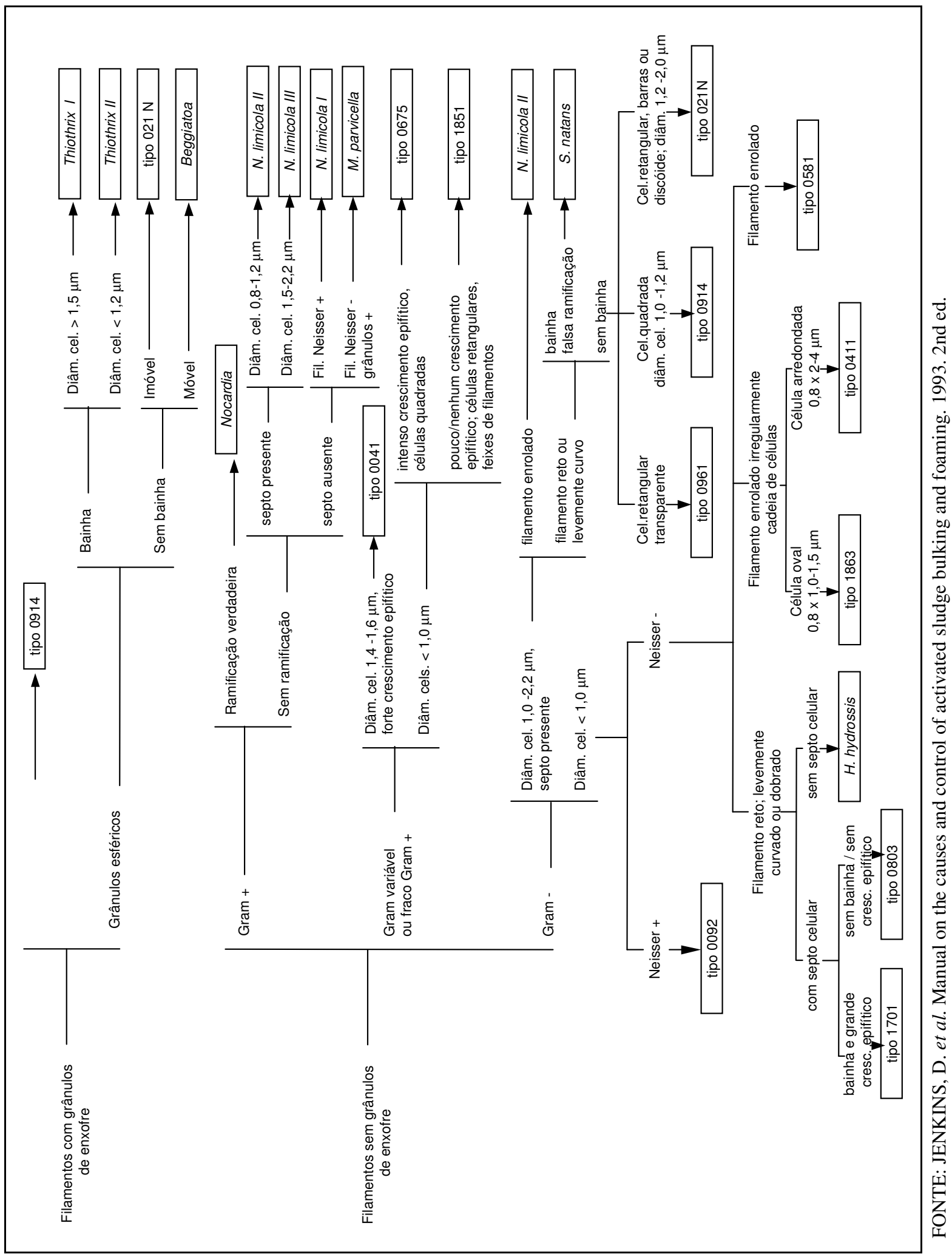




\subsection{Aplicação e influência de ácido fólico em reatores de tratamento biológico de esgotos de lodos ativados}

Segundo Senörer (2001), devido à diversas razões, as estações de tratamento de esgotos apresentam eficiência baixa do tratamento de águas residuárias, e algumas pesquisas desenvolvidas nos últimos anos sugerem que o provável fator que a propicia é a deficiência de vitaminas, sendo entre estas o ácido fólico como a mais importante ao tratamento biológico geralmente encontrada em quantidades limitadas.

De acordo com pesquisa desenvolvida nos Estados Unidos por Anderl (1987), cerca de $65 \%$ das estações de tratamento biológico de esgotos de lodos ativados apresentam deficiência de vitaminas. Entre 71 estações que foram selecionadas e monitoradas, foi verificada a deficiência das seguintes vitaminas: cianocobalamina (vitamina $B_{12}$ ), em 4 estações; riboflavina (vitamina $\mathrm{B}_{2}$ ), em 4 estações; ácido pantotênico (vitamina $\mathrm{B}_{5}$ ), em 7 estações; tiamina (vitamina $B_{1}$ ), em 10 estações; e ácido fólico (vitamina $B_{9}$ ), em 21 estações. Segundo o autor, o ácido fólico apresentou-se disponível em concentrações muito pequenas ou até ausente no lodo de algumas das estações pesquisadas.

Devido à sua característica essencial, o ácido fólico não pode ser substituído por outra vitamina ou substância, atuando como um fator limitante se não estiver disponível em concentração adequada. Isso ocorre com alguns gêneros de bactérias, que podem ter seus processos metabólicos limitados, como por exemplo, as bactérias responsáveis pela nitrificação e pela desnitrificação (Lemmer et al, 1997). 
A adição de vitaminas necessárias ao crescimento dos microrganismos no reator biológico e disponíveis à assimilação dos mesmos pode reduzir a deficiência destas, evitando a interferência no crescimento, e aumentando a atividade do lodo biológico, sendo possível desta forma otimizar a eficiência da depuração (Lemmer et al, 1997).

Em tratamento secundário de esgotos domésticos, especialmente o de lodos ativados, tem sido feita adição de ácido fólico há muitos anos, sendo utilizado em mais de cem estações de tratamento de esgotos municipais e industriais na Europa e nos Estados Unidos (Dubé et al, 2002); no Brasil, a utilização de ácido fólico tem sido implementada em estações de tratamento biológico de lodos ativados desde 1999 (Conchon, 1998).

Em decorrência do interesse na utilização de ácido fólico como bio-estimulador em estações de tratamento de esgotos, foram desenvolvidas algumas pesquisas em vários países sobre os efeitos desta vitamina nos microrganismos. Segundo Conchon (1998), avaliando as características das ETEs que empregaram solução de ácido fólico, observou-se o aumento da eficiência do tratamento biológico de esgotos, apresentando como resultado redução de DBO acima de $95 \%$. Além disso, observou-se que restaram sólidos sedimentáveis no efluente final com concentração abaixo de $1 \mathrm{ml} / \mathrm{L}$. Os sólidos em suspensão totais (SST) no efluente tratado mantiveram os níveis normais, não apresentando aumento significativo, com concentração de SST em média abaixo de $60 \mathrm{mg} / \mathrm{L}$.

Conchon (1998) também verificou nestas pesquisas que a aplicação de solução de ácido fólico aumentou a diversidade, população e atividade dos microrganismos componentes da microfauna; controlou o crescimento de bactérias filamentosas, evitando a ocorrência de intumescimento ou bulking filamentoso; além de propiciar a formação de flocos maiores e mais compactos, melhorando assim as características de sedimentabilidade do lodo. 
Segundo Mohr (1987), o ácido fólico exerce dois mecanismos característicos na ação dos microrganismos, primeiramente, age como um micronutriente para certas bactérias e, secundariamente, estimula o crescimento dos microrganismos pela sua ação de vitamina. Uma vez que a atividade enzimática global dos microrganismos é limitada, o ácido fólico aumenta a atividade de algumas cadeias metabólicas, aumentando assim a capacidade por diferentes processos metabólicos, no consumo de diversos tipos de nutrientes. Desta forma, o ácido fólico otimiza o metabolismo enzimático de bactérias.

\subsubsection{Características do ácido fólico}

O ácido fólico é uma vitamina hidrossolúvel pertencente ao grupo de vitaminas do complexo $\mathrm{B}$, consistindo na vitamina $\mathrm{B}_{9}$. O termo fólico é derivado da palavra do latim folium, significando folhas, e folato é o termo genérico utilizado para uma grande família de compostos semelhantes quimicamente (Droguetti \& Penteado, 2003). O ácido fólico também tem as denominações vitamina $\mathrm{B}_{\mathrm{C}}$ e ácido pteroilglutâmico (O'Neil, 2001).

Esta vitamina foi descoberta em 1930, sendo observada por Lucy Wills, que associou casos deficiência desta vitamina pela dieta humana com casos de anemia perniciosa. A molécula de ácido fólico foi primeiramente isolada de folhas de espinafre, fato que conduziu ao nome desta vitamina, e foi sintetizado com sucesso somente a partir de 1946 (Donnelly, 2001). 
O ácido fólico é cofator de muitas enzimas, estando envolvido em várias reações intracelulares. Ele deriva das estruturas pteridina e pterina, que ocorrem largamente na natureza. As bactérias e as plantas são capazes de sintetizar ácido fólico - bactérias sintetizam ácido fólico através de precursores, incluindo ácido p-aminobenzóico, enquanto que outros organismos, como os mamíferos, são incapazes de sintetizar ácido fólico e este deve ser obtido pela dieta, através da ingestão de alimentos que constituem fonte de folato, como vegetais de folhas verdes, frutas, fungos, fígado bovino, etc. (Garret \& Grisham, 1995; Donnelly, 2001).

$\mathrm{O}$ ácido fólico, cuja fórmula química é $\mathrm{C}_{19} \mathrm{H}_{19} \mathrm{~N}_{7} \mathrm{O}_{5}$, é composto por três blocos construtivos característicos: um composto nitrogenado pteridina, uma molécula de ácido paminobenzóico (PABA) e uma ou mais moléculas de ácido glutâmico. A pteridina é o composto nitrogenado, das pterinas, que são derivados do 2-amino-4-hidropteridina (Lehninger et al., 2000; Garret \& Grisham, 1995; Champe, 1996). A estrutura química do ácido fólico está apresentada na Figura 5.

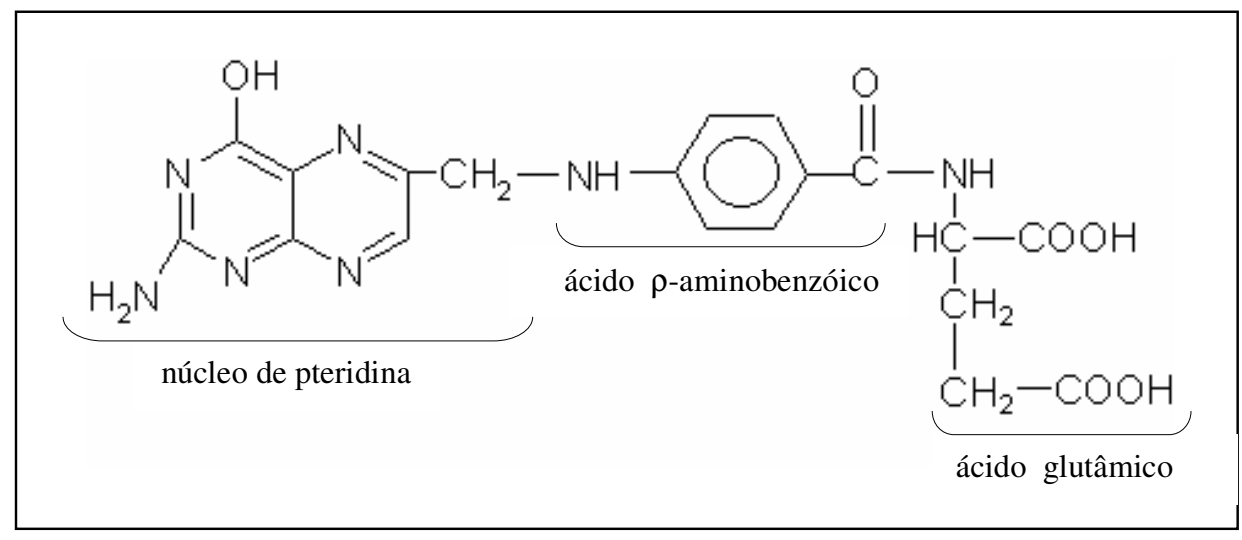

Figura 5 - Estrutura química do ácido fólico (FONTE: Sackheim \& Lehman, 2001)

Segundo as propriedades químicas e físicas, o ácido fólico apresenta-se como cristais amarelos, tendo o peso molecular de 441,4. Essa vitamina é levemente solúvel em água na 
forma ácida, mas bastante solúvel em soluções alcalinas. Tetraidrofolatos em solução são sensíveis ao oxigênio, à luz e a pH extremos (Droguetti \& Penteado, 2003).

Em relação à estabilidade química, estudos sobre a oxidação do ácido fólico demostram que a exposição à luz, calor e pH são os principais fatores que causam efeitos destrutivos em solução de ácido fólico. Uma vez que são suscetíveis a estas condições, se soluções de ácido fólico forem protegidas da luz e mantidas sob temperaturas moderadas os folatos são mais estáveis (John \& Newman, 1985). Com relação ao pH, a taxa de degradação é variável de acordo com o pH da solução sendo gradualmente diminuída do ácido ao alcalino e pH entre 6 a 7 parece ser uma melhor escolha para a manutenção do $\mathrm{pH}$ de soluções contendo preparações líquidas de ácido fólico. Segundo Akhtar et al. (1999), as soluções de ácido fólico demonstram estabilidade ótima com pH 7,6.

A partir das reações de degradação do ácido fólico em solução aquosa, os principais produtos destas tem sido identificados como p-amino-benzoil-L-ácido glutâmico e pterina-6ácido carboxílico com traços de ácido p-aminobenzóico, os quais podem ser identificados através de análise pelo método de HPLC (Akhtar et al., 1999), sendo que estudos mostram o uso efetivo de uma variedade de técnicas cromatográficas para investigar as propriedades químicas dos derivados de folatos. 


\subsubsection{Importância e metabolismo do ácido fólico nos organismos}

Todas as células necessitam de ácido fólico para a síntese de DNA e divisão celular, uma vez que o ácido fólico, na forma de tetraidrofolato, atua na biossíntese das bases nitrogenadas pirimidina e da purina, que apresentam os nucleotídeos que constituem a fita de DNA (purinas: adenina e guanina; pirimidina: citosina e timina). Há complementaridade das purinas e pirimidinas, por meio de projeções onde as duas fitas de DNA apresentam ligações cruzadas, de forma que a seqüência de bases em uma das fitas ordena a seqüência da outra. Isto é de importância fundamental na síntese de novas fitas de DNA durante a divisão celular, uma vez que esta é a seqüência de bases no DNA que representa a informação genética da célula (Pelczar et al., 1996).

O sintoma bioquímico mais evidente da deficiência de ácido fólico é a biossíntese de purina e timina prejudicada (Lehninger et al., 2000). Além disso, se há quantidade insuficiente de ácido fólico, os cromossomos podem quebrar nesses sítios frágeis (Pelczar et al., 1996), uma vez que a deficiência deste provoca a inibição da timidilato sintetase, enzimachave na síntese de DNA (Guilland \& Lequeu, 1995).

As várias coenzimas de folatos facilitam a transferência de unidades de um carbono (unidades $\mathrm{C}_{1}$, como $-\mathrm{CHO},-\mathrm{CH}_{2} \mathrm{OH}$ e $-\mathrm{CH}_{3}$ ), a partir de moléculas doadoras em importantes processos de biossíntese, como na formação de purina, pirimidina e metionina. Elas também são mediadoras da interconversão de serina e glicina e participam do catabolismo da histidina (Bonechi et al, 2004). A molécula que participa destas reações é a forma reduzida do ácido fólico, uma vez que este deve ser enzimaticamente reduzido para se tornar uma coenzima biologicamente ativa - o tetraidrofolato, que atua como fator de crescimento e como cofator 
em muitas vias metabólicas, sendo produzido em uma reação de duas reduções sucessivas de folato, pela diidrofolato redutase (Vieira et al., 1979; Garret \& Grisham, 1995; Champe, 1996; Murray et al., 1998; Lehninger, 2000), como mostrado na Figura 6 (Voet, 2002).

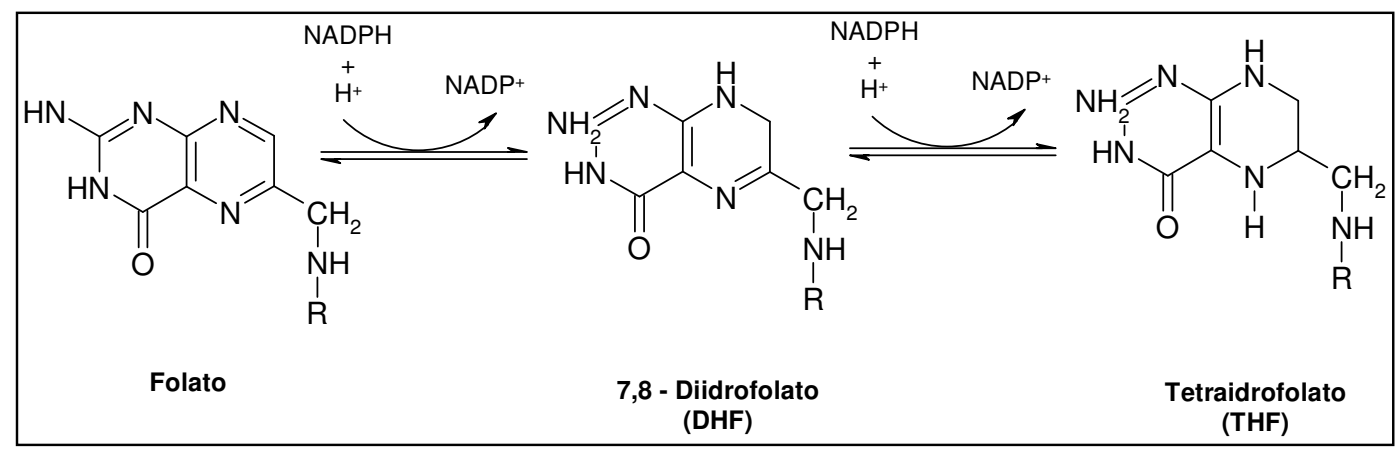

Figura 6. Etapas da reação de redução de ácido fólico a tetraidrofolato FONTE: Voet, 2002

O tetraidrofolato é derivado de 6-metilpterina, unido a um ácido p-aminobenzóico e a um resíduo glutamato, enquanto que o ácido fólico é uma forma duplamente oxidada de tetraidrofolato (Sackheim \& Lehman, 2001). A importância do tetraidrofolato no metabolismo dos microrganismos está ilustrada na Figura 7.

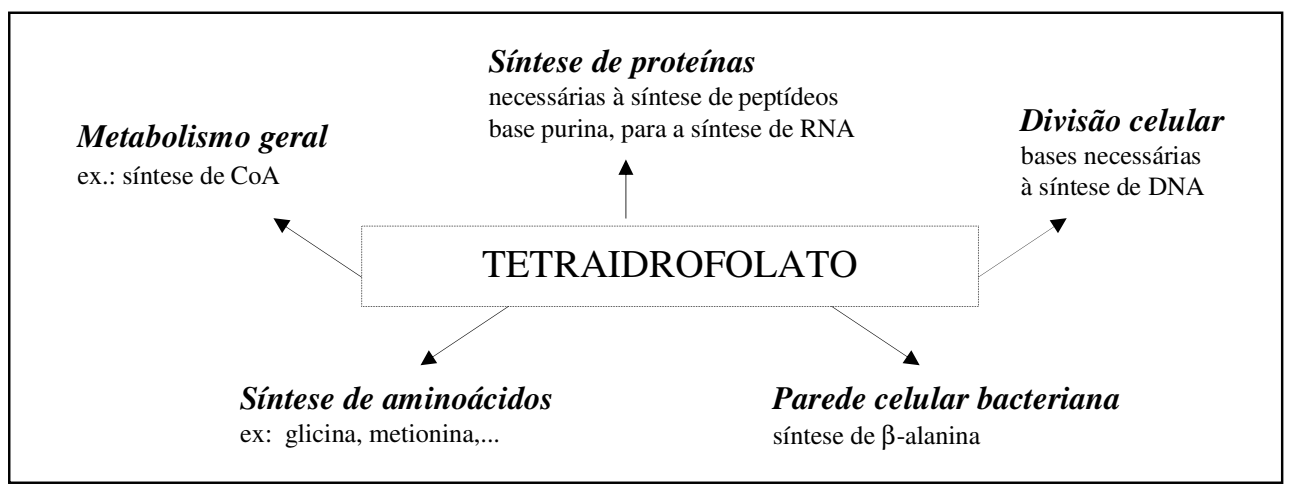

Figura 7 - Importância do ácido tetrahidrofólico aos microrganismos

FONTE: Adaptado de "Dosfolat $® X S$ reduces waste sludge in biological sewage treatment plants" (http://www.dosfolat.de/product/prod_fig2.html, 21/06/04) 
As reações em que o tetraidrofolato participa estão apresentadas na Figura 8, segundo Garret \& Grisham (1995).

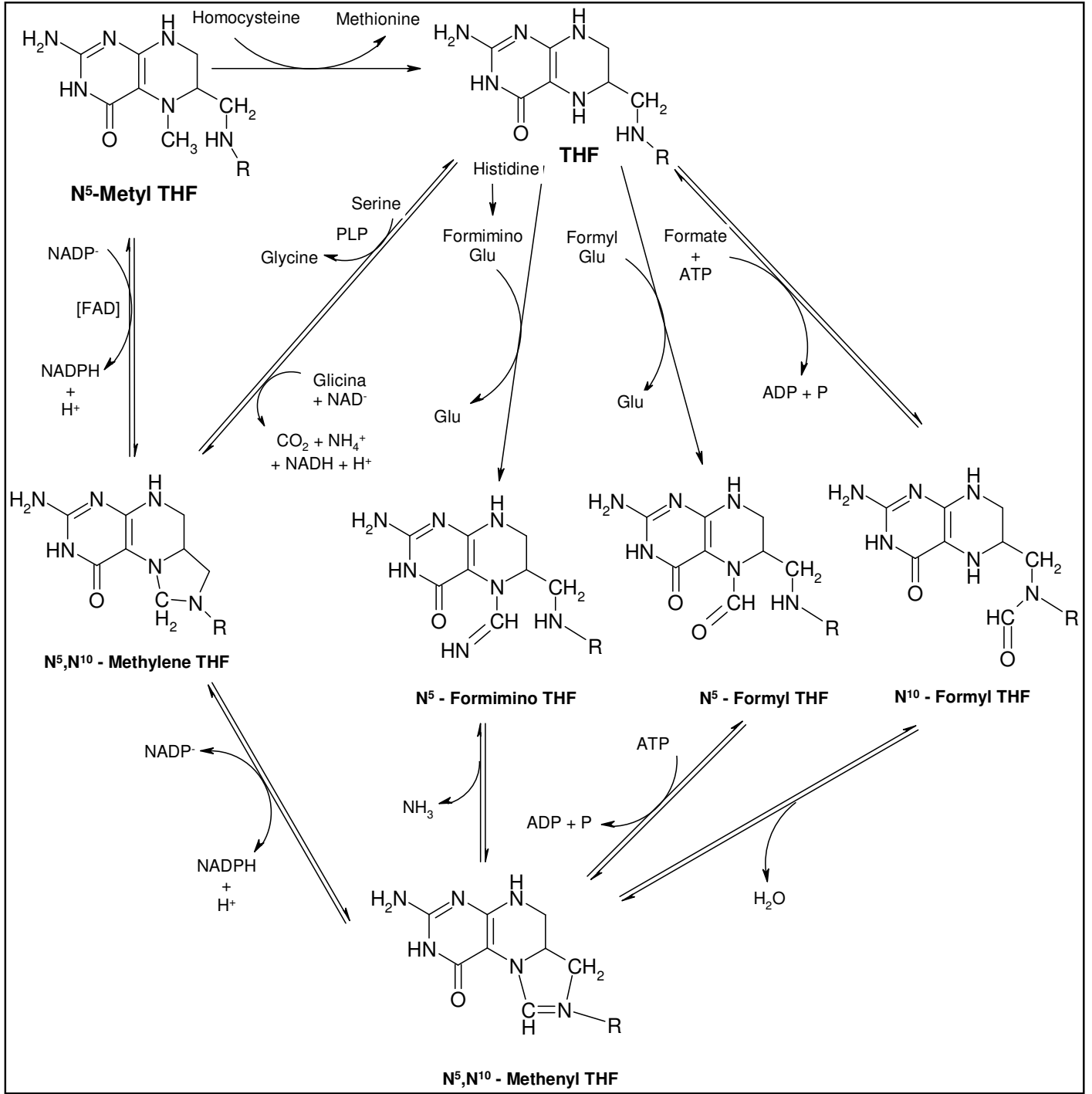

Figura 8 - Reações dependentes do tetraidrofolato (FONTE: Garret \& Grisham, 1995)

Nas células, o metabolismo envolve cada uma das três reações, chamadas de poliglutamato, redução de dihidrofolatro a tetraidrofolato e a transformação e transferência de unidades de carbono. Intracelularmente, os locais onde o folato participa de reações químicas são o citoplasma e a mitocôndria. Dentro do citoplasma, o folato é um cofator do metabolismo de aminoácidos, catabolismo de histidina e a regeneração de metionina a homocisteína e 
síntese de purina de espécies monocarbônicas. Na mitocôndria, o folato está envolvido com a formação de glicina e serina, bem como na oxidação da glicina a dióxido de carbono e amônia (Donelly, 2001 apud Green et al., 1988; Bayly et al., 2001).

A enzima serina hidroximetila transferase, também chamada de treonina aldolase, está envolvida no metabolismo de ácido fólico em todos os organismos. Essa enzima é essencial na regeneração do tetraidrofolato, a partir da sua forma metilada (5,10-metileno tetraidrofolato) e catalisando a síntese de glicina e 5,10-metileno tetraidrofolato, a partir de serina e tetraidrofolato (Chaves et al., 2003).

Organismos procariotontes, eucariotontes microbianos e plantas sintetizam folato usando a via do ácido fólico. Alguns organismos requerem somente a porção do ácido paminobenzóico do ácido fólico, e eles podem sintetizar o ácido fólico quando este está disponível (Garret \& Grisham, 1995; Champe, 1996; Lehninger, 2000).

Nos organismos eucariontes (como a espécie humana) a ingestão de quantidades adequadas de folato é essencial para a homeostase, devido ao papel essencial das folatocoenzimas necessárias ao metabolismo normal. Níveis inadequados de folato associados à mudanças bioquímicas permitem o aparecimento de anormalidades no metabolismo do carbono (Droguetti \& Penteado, 2003 apud Wagner, 1995).

Na espécie humana, a deficiência severa de folato leva a um tipo específico de anemia, a anemia megaloblástica. Além da anemia resultante, a diminuição da divisão celular também ocasiona números menores de plaquetas e células brancas. Isso ocorre devido a um impedimento da divisão celular relacionado ao papel do folato na síntese de ácido nucléico, processo que é mais aparente em tecidos que se renovam rapidamente, tais como no sistema 
hematopoiético e nas células do trato digestivo (Droguetti \& Penteado, 2003 apud Lindenbaum \& Allen, 1995).

Durante quase cinqüenta anos após a sua descoberta, acreditou-se que a única conseqüência da deficiência de folato na dieta humana era a anemia. No entanto, hoje sabe-se que o folato, em sua forma natural, adquirido através da alimentação, ou como suplemento vitamínico, apresenta efeito benéfico na prevenção de várias doenças, uma vez que quantidades insuficientes de ácido fólico têm sido associadas com a ocorrência de vários problemas de saúde, como doenças cardiovasculares e problemas durante o desenvolvimento embrionário, como a má formação do tubo neural. Este último explica-se pelo fato de o início de desenvolvimento fetal do tubo neural ser extremamente dependente da presença de ácido fólico, por este ser um nutriente indispensável à todas as divisões celulares (Guilland \& Lequeu, 1995).

Inclusive, alguns estudos relacionam a ingestão inadequada de folato como um fator que propicia o desenvolvimento de certos tipos de câncer, considerando como hipóteses o papel do folato na estrutura do DNA, estabilidade e transcrição; incluindo a suscetibilidade do DNA de sofrer quebras na cadeia e instabilidade cromossômica (Droguetti \& Penteado, 2003 apud Blount et al., 1997). A dose diária mínima de ácido fólico requerida pelos organismos de adultos tem sido estimada em $50 \mu \mathrm{g}$, enquanto para gestantes é recomendado $400 \mu \mathrm{g}$ por dia (Bonechi et al., 2004 apud Crittenden, 2002).

Assim, esta vitamina, antes tida somente como um fator de prevenção de anemia megaloblástica, com o desenvolvimento de pesquisas tornou-se um composto de interesse, principalmente a partir da descoberta de que os folatos podem ser utilizados na prevenção de 
doenças, no desenvolvimento de antibióticos e agentes quimioterápicos contra o câncer (Droguetti \& Penteado, 2003).

\subsubsection{Características do composto a base de ácido fólico empregados em ETEs}

A necessidade de uma tecnologia que aumentasse o metabolismo celular, diminuindo o ciclo reprodutivo, as dificuldades em se estabelecer metodologias para dosagens adequadas de ácido fólico e a manutenção das suas características estáveis foram problemas encontrados diante de sua aplicação em reatores de tratamento de esgotos, uma vez que a vitamina é facilmente degradada pela influência de oxidação, redução, metais pesados, calor e luz. A partir destas dificuldades, houve o interesse em se desenvolver uma solução estabilizada e solúvel em água, para ser comercializada e utilizada em estações de tratamento (Bioprime, 2003).

Assim, foi produzida em através de processo bioquímico uma solução composta por ácido fólico e outros compostos, destinada à aplicação em reatores de tratamento de esgotos. Esta tem a denominação comercial de Dosfolat ${ }^{\circledR}$, foi desenvolvido na Alemanha em 1983, pela indústria Alphachemie, e vem sendo aplicado desde então em estações de tratamento de esgotos municipais e industriais de muitos países, como Argentina, Brasil, Canadá, Dinamarca, França, Alemanha, Israel, Itália, México, Noruega, Suécia, Turquia e Estados Unidos (Bioprime, 2003; EPA, 2003).

O composto Dosfolat é uma solução aquosa que consiste em $30 \%$ de ácido fólico, traços de molibdo-pterina, que é um fator complexo essencial nas reações de nitrificação, além de 
outros compostos. A formulação do produto é patenteada e a sua composição é mantida como segredo industrial, segundo informações do fabricante, o composto possui componentes que visam reduzir a degradação destes, mantendo sua estabilidade no efluente (Bioprime, 2003).

Este composto é comercializado sob a forma líquida, em galão de polietileno de 4,04 $\mathrm{Kg}$, sendo embalado em atmosfera inerte de nitrogênio para preservação da qualidade. Segundo instruções do fabricante Alphachemie, apresentadas em manual descritivo e de utilização, não há necessidade de manter a solução refrigerada, no entanto, é recomendado armazenar o produto em temperaturas entre $8^{\circ}$ a $28^{\circ} \mathrm{C}$, sendo que acima de $35^{\circ} \mathrm{C}$, o prazo de validade do produto diminui. A validade do Dosfolat em embalagem lacrada é de 12 meses, e após o preparo de solução com diluição para aplicação, esta deve ser utilizado num período de 14 dias.

É orientado pelo fabricante do composto que este deve ser aplicado na linha de retorno de lodos ativados ou no efluente do tanque de aeração, próximo à entrada de efluente, sendo necessário prover uma mistura adequada neste. Também segundo informações do fabricante, a aplicação do produto não deve ser interrompida, pois a dosagem contínua de ácido fólico no sistema é tão importante quanto à concentração ideal a ser dosada. No início de utilização de Dosfolat, recomenda-se a aplicação de dosagem de choque para adaptação da biomassa, com concentração de $0,5 \mathrm{mg} / \mathrm{L}$, durante um período de 14 dias. Após este período, é mantida aplicação de dosagem contínua, de $0,1 \mathrm{mg} / \mathrm{L}$. Para o preparo das soluções para adição no tanque de aeração, deve ser utilizada água destilada para diluição.

A limitação do uso de Dosfolat se restringe à possibilidade de aplicação somente em sistemas de tratamento biológicos, onde os níveis dos macronutrientes nitrogênio e fósforo devem ser adequados (Bioprime, 2003; EPA, 2003). 


\subsubsection{Resultados verificados com a utilização do produto a base de ácido fólico empregado em ETEs}

Reportando dados da literatura, foi possível observar através de algumas pesquisas que a aplicação de ácido fólico no tratamento secundário aumenta a eficiência do tratamento, com a redução de sólidos em suspensão totais e de DBO, apresentando o potencial de prover benefícios do ponto de vista ambiental, operacional e econômico. Segundo Dubé et al (2002), estes aspectos abrangem uma redução considerável na produção de lodo, controle do intumescimento filamentoso e melhores condições de sedimentabilidade e adensabilidade do lodo no decantador secundário. Neste caso, o ácido fólico é uma alternativa efetiva para substituir a aplicação de cloro, peróxido de hidrogênio ou outros produtos químicos que são comumente utilizados em estações de tratamento como métodos alternativos para o controle do intumescimento filamentoso. Além destes aspectos, observou-se que o composto afeta o metabolismo do nitrogênio, otimizando a nitrificação no tanque de aeração, aumentando a remoção de nitrogênio amoniacal.

Ostrander (1992) desenvolveu pesquisa em uma estação municipal de tratamento de esgotos e observou que o tratamento secundário com suplementação de ácido fólico melhora significativamente o desempenho do tratamento de esgotos. Como um micronutriente e coenzima, sendo essencial ao crescimento e metabolismo de todas as células, a aplicação de ácido fólico no reator biológico favoreceu o aumento da diversidade, população e atividade dos microrganismos, conduzindo a uma maior eficiência e melhor sedimentação, possibilitando assim um efluente mais clarificado. Os resultados apresentados pelo autor, a partir de pesquisas práticas, incluem a redução de sólidos suspensos no efluente final, redução de DQO e DBO, redução do lodo e operação mais estável. Também foi realizado exame 
microscópico e contagem de microrganismos do lodo, onde verificou-se que após uma semana de aplicação de ácido fólico, protozoários ciliados livre-natantes substituíram os flagelados como microrganismos dominantes. Ao final da semana seguinte, os ciliados pedunculados tornaram-se dominantes e permaneceram assim até o fim da pesquisa. Logo após os ciliados pedunculados se tornarem predominantes, não ocorreu mais problemas de intumescimento filamentoso, melhorando muito a sedimentabilidade do lodo.

Akerboom et al. (1994), pesquisando duas estações de tratamento de efluente de indústria de papel reciclado, cujos reatores recebiam adição de solução de ácido fólico, observou como resultados a minimização dos problemas operacionais comuns, uma vez que a partir da adição desta vitamina, verificou-se a sedimentabilidade do lodo melhor, maior estabilidade na operação do processo, significante redução da quantidade de lodo gerado, controle do crescimento de bactérias filamentosas e efluente final mais clarificado. Segundo os autores, o estabelecimento destas condições possibilitaram a redução do consumo de aditivos químicos, como polímeros para otimizar a floculação e cloração para controle de filamentosas (normalmente utilizados na prática). Exames microscópicos de amostras de lodo destas estações indicaram que nos reatores com a aplicação de ácido fólico houve um crescimento mais diversificado da microfauna, especialmente da população de protozoários, e um aumento da atividade da biomassa.

Senörer (2001) pesquisou a ação do ácido fólico na eficiência de estações com a aplicação desta vitamina. Duas estações de tratamento foram avaliadas, uma que trata 300 $\mathrm{m}^{3} /$ dia esgoto doméstico e outra que trata $250 \mathrm{~m}^{3} /$ dia de efluente industrial*. Com a introdução de ácido fólico em ambas as estações, verificou-se como resultado que o efluente da estação de tratamento de água residuária industrial apresentou concentrações de DQO 
entre 88 a $106 \mathrm{mg} / \mathrm{L}$, enquanto que no efluente da estação de tratamento de esgoto doméstico a concentração de DQO foi reduzida para concentrações menores que $60 \mathrm{mg} / \mathrm{L}$. Assim, foi verificado um aumento significativo da eficiência de remoção de DQO,

comparativamente à operação sem adição de ácido fólico, e sendo obtida estabilidade nas concentrações de DQO de ambos os efluentes. Verificou-se também uma menor eficiência dos tratamentos quando foi reduzida a concentração de ácido fólico aplicado continuamente, de $1 \mathrm{mg} / \mathrm{L}$ para $0,2 \mathrm{mg} / \mathrm{L}$, em que as concentrações de DBO e DQO aumentaram de 80 a $100 \%$ no efluente final.

Um dos resultados mais significativos apresentados nestas pesquisas, obtidos através da aplicação de Dosfolat, refere-se à reduzida produção de lodo gerado. Através de experiências práticas realizadas desde o ano de 1983 (Senörer, 2001), quando o composto começou a ser aplicado em estações de tratamento biológico de esgotos, verificou-se que a aplicação contínua deste propicia uma redução de cerca de $30 \%$ da quantidade de lodo gerado.

Segundo Anderl (1987), a utilização de ácido fólico em estações de tratamento é baseada na obtenção de resultados práticos em relação ao desempenho e à eficiência, e o desenvolvimento de pesquisas com o objetivo de redução de lodo através do emprego de ácido fólico baseou-se no pressuposto de que para diminuir a geração de lodo deve-se aumentar a idade do lodo no sistema, o que comumente apresenta como implicações a proliferação excessiva de bactérias filamentosas, desfloculação, acúmulo de carga de sólidos no decantador, e, decorrente de todos estes fatores, baixa eficiência global da estação de tratamento de esgotos.

\footnotetext{
* Nota: O autor não especificou o tipo de efluente e atividade desta indústria
} 
Segundo Bioprime (2003) e EPA (2003), outro aspecto do Dosfolat diz respeito às características operacionais, uma vez que o produto propicia estabilidade do lodo, evitando problemas em resposta a possíveis alterações na vazão, carga, temperatura e choques tóxicos. Em relação à este último aspecto, alguns autores observaram que quando o Dosfolat está sendo aplicado no reator biológico, a estação de tratamento torna-se menos suscetível a choques tóxicos, como determinadas substâncias tóxicas como fenol, nonilfenol, tiofenol, etoxilato, laurilsulfato, ou o antibiótico penicilina, tendo seus efeitos tóxicos parcialmente ou totalmente neutralizados.

Segundo Conchon (1998), a partir do período de dosagem de choque da solução de ácido fólico em reatores de lodos ativados, observou-se o aumento e predominância de bactérias formadoras de flocos, aumento da taxa de respiração - estabilizada em $25 \mathrm{mgO} / \mathrm{h} / \mathrm{kg}$ SSV, aumento da concentração de sólidos no reator biológico, e aumento da eficiência de remoção da matéria orgânica - sistemas de tratamento tiveram inicialmente remoção de DQO de $85 \%$ e chegaram a uma remoção de $93 \%$.

Em relatório da Bioprime (2003) verificou-se a ocorrência das mesmas características nos reatores a partir da aplicação de ácido fólico, salientando a importância de se estabelecer o monitoramento de parâmetros representativos do comportamento do reator biológico e da eficiência do tratamento, como sólidos em suspensão totais, sólidos sedimentáveis, DQO ou DBO e observações microscópicas. Os resultados sugeriram que os ciclos de reposição da microbiota são lentos e, conseqüentemente, as perdas são substituídas lentamente, evitando o aumento de sólidos. 


\subsection{Bioensaios de respirometria}

Numa das etapas deste estudo foram empregados bioensaios de respirometria, sob condições aeróbias controladas - o teste de demanda bioquímica de oxigênio (DBO), a fim de avaliar os efeitos da adição de ácido fólico na atividade metabólica da microbiota de lodos ativados.

A determinação da atividade microbiana é importante na análise do processo de tratamento de águas residuárias, uma vez que a degradação de matéria orgânica e a produtividade do sistema dependem da atividade dos microrganismos metabolicamente ativos. A atividade de bactérias em lodos ativados é geralmente avaliada pela medição de parâmetros operacionais, entre os quais um dos mais importantes é a taxa de consumo de oxigênio, que representa a velocidade de respiração dos microrganismos presentes no sistema (Fernandes et al., 2001), e reflete a atividade metabólica de uma população microbiana, determinada pelo consumo de oxigênio decorrente das reações bioquímicas de seus processos metabólicos (Griebe et al., 1997).

As técnicas respirométricas são baseadas na medida e interpretação do consumo biológico de oxigênio, devido à respiração aeróbia de uma população microbiana sob determinadas condições, medindo a quantidade de oxigênio por unidade de tempo e de volume que é consumida pelos microrganismos em lodos ativados (Gernaey et al., 2001). Para a determinação respirométrica, é utilizado respirômetro, que consiste em um pequeno reator biológico destinado a medir a respiração aeróbia de uma população microbiana, sendo o oxigênio dissolvido medido na fase líquida. O respirômetro determina a quantidade de oxigênio consumida, sendo este diretamente relacionado com o crescimento bacteriano e com o consumo de substrato para a obtenção de energia (Carmona et al., 2004). 


\section{MATERIAL E MÉTODOS}

\subsection{Considerações gerais}

A parte experimental deste trabalho foi desenvolvida em duas etapas: a primeira com a realização de bioensaios de respirometria, a fim de verificar o consumo de oxigênio dissolvido pelos microrganismos presentes em lodos ativados, em amostras de lodo com adição de solução de ácido fólico. A segunda etapa foi a implantação e operação de estação piloto de lodos ativados em batelada, instalada no Laboratório de Saneamento, para avaliar a influência do ácido fólico puro e do Dosfolat na dinâmica da microfauna e no desempenho geral do tratamento.

\subsection{Bioensaios de respirometria}

Entre a ampla variedade de bioensaios encontrados na literatura optou-se pela técnica respirométrica, por refletir a atividade metabólica de uma população microbiana, determinada pelo consumo de oxigênio decorrente das reações bioquímicas dos processos metabólicos dos microrganismos. Neste estudo foram empregados ensaios sob condições aeróbias controladas - o teste de demanda bioquímica de oxigênio (DBO), a fim de avaliar os efeitos do estímulo da respiração basal com a adição de ácido fólico na microbiota de lodos ativados.

Nestes bioensaios de respirometria foram efetuadas medidas da concentração de oxigênio dissolvido em amostras de lodos ativados diluídas, antes e após períodos de incubação estabelecidos, determinando-se o consumo de oxigênio pelo inóculo em frascos de 
DBO com adição de ácido fólico, comparado ao consumo de oxigênio do mesmo inóculo em frascos sem adição desta vitamina (controle).

\subsubsection{Origem do lodo utilizado como inóculo nos ensaios}

As amostras de lodo utilizadas como inóculo nos cinco bioensaios foram provenientes da Estação de Tratamento de Esgotos do ABC (ETE ABC), operada pela Companhia de Saneamento Básico do Estado de São Paulo - Sabesp, cujo processo de tratamento é de lodos ativados convencional. A ETE ABC é integrante do sistema de tratamento de esgotos da região metropolitana de São Paulo, e está situada neste município, próximo à divisa territorial entre os municípios de São Paulo e São Caetano do Sul, servindo as cidades de Santo André, São Bernardo, Diadema, São Caetano, Mauá e parte da cidade de São Paulo, recebendo esgotos predominantemente domésticos, apresentando capacidade de tratamento de vazão média de $3,0 \mathrm{~m}^{3} / \mathrm{s}$ (Sabesp, 2004).

As amostras foram coletadas na linha de retorno desta estação, em ponto do decantador secundário ao tanque de aeração. A justificativa para a utilização de inóculo desta estação de tratamento foi em função das características estáveis do processo, sobretudo em relação aos características microbiológicos, como a diversidade da microfauna, boa formação e composição dos flocos e quantidade relativa equilibrada de bactérias filamentosas. 


\subsubsection{Descrição dos bioensaios de respirometria}

Nestes ensaios, foram testadas concentrações diferentes de ácido fólico, da marca Nuclear, introduzidas em frascos de vidro para DBO de 300ml, providos de tampa vedante e mostrados na Figura 9. Alíquotas de amostra de lodo da ETE ABC foram inseridas nos frascos, sendo em seguida preenchidos com água destilada saturada de oxigênio, com solução nutritiva, consistindo da adição de cálcio, ferro e magnésio, além de uma solução tampão de fosfato. As soluções foram adicionadas para garantir um meio favorável ao metabolismo dos microrganismos envolvidos no teste.

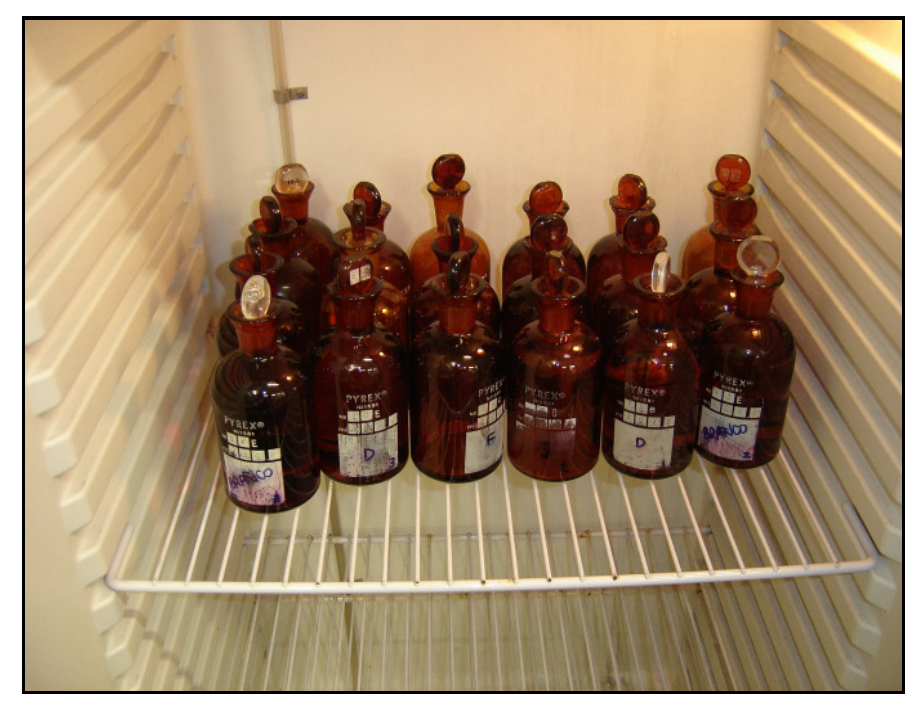

Figura 9 - Vista dos frascos de DBO em incubação a $20^{\circ} \mathrm{C}$, durante bioensaio de respirometria

A metodologia utilizada para os ensaios de DBO foi efetuada de acordo com os procedimentos apresentados no "Standard Methods for the Examination of Water and Wastewater", 20ª ed. (APHA, 1998), considerando a diluição de amostras e incubação por um período de 5 dias a $20^{\circ} \mathrm{C}$, após o que foram quantificadas as concentração de oxigênio dissolvido nos frascos de DBO. A fim de determinar a depleção do oxigênio ocorrido nos 
frascos durante a incubação, o oxigênio dissolvido foi analisado pelo método eletrométrico, utilizando um aparelho oxímetro, da marcaYellow Springs, modelo YSI-5100.

Foram realizados cinco bioensaios respirométricos, sendo que nos dois primeiros ensaios, o consumo do oxigênio nos frascos foi determinado após o período de incubação de cinco dias. Valores do oxigênio foram também obtidos no início dos testes. Nos outros três bioensaios realizados, o oxigênio foi quantificado nos frascos diariamente no decorrer do período.

As soluções de ácido fólico empregadas em cada um dos ensaios foram preparadas no mesmo dia da incubação dos frascos, a fim de garantir a qualidade das mesmas. As condições dos cinco bioensaios estão apresentadas na Tabela 7.

TABELA 7 - CARACTERÍSTICAS DOS BIOENSAIOS DE RESPIROMETRIA

\begin{tabular}{|c|c|c|c|c|}
\hline BIOENSAIOS & $\begin{array}{c}\text { CONCENTRAÇÕES } \\
\text { DE ÁCIDO FÓLICO } \\
(\mathrm{mg} / \mathrm{L})\end{array}$ & $\begin{array}{l}\text { VOLUME DE LODO } \\
\text { UTILIZADO COMO } \\
\text { INÓCULO }(\mathrm{ml})\end{array}$ & $\begin{array}{c}\text { MEDIDAS DO } \\
\text { CONSUMO DE OD } \\
\text { (OD INICIAL E OD } \\
\text { FINAL) } \\
\end{array}$ & $\begin{array}{l}\text { PREPARO DA } \\
\text { SOLUÇÃO DE } \\
\text { ÁCIDO FÓLICO }\end{array}$ \\
\hline 1 & 1 e 2 & 0,$1 ; 0,5 ; 1,0 ; 1,5$ e 2,0 & $1^{\circ}$ e $5^{\circ}$ dia & \multirow{2}{*}{$\begin{array}{l}-* \\
\text { dissolução com água } \\
\text { fervente }\end{array}$} \\
\hline 2 & 2,5 e 4,0 & 0,$1 ; 0,3 ; 0,5 ; 1,0$ e 1,5 & $1^{\circ}$ e $5^{\circ}$ dia & \\
\hline 3 & 2,5 e 4,0 & 0,5 & medidas diárias & \multirow{3}{*}{$\begin{array}{c}\text { dissolução com } \\
\text { bicarbonato de sódio }\end{array}$} \\
\hline 4 & $0,5,2,5$ e 4,0 & 05 & medidas diárias & \\
\hline 5 & $2,5 * 1$ & 0,5 & medidas diárias & \\
\hline
\end{tabular}

No Bioensaio 1, testou-se as concentrações de 1,0 e 2,0 mg/L de ácido fólico, e este não foi previamente dissolvido para o preparo da solução a ser introduzida nos frascos. Procedeuse cinco diluições diferentes da amostra de lodo tomada como inoculo, sendo utilizados os seguintes volumes: 0,$1 ; 0,5 ; 1,0 ; 1,5$ e $2,0 \mathrm{ml}$, para ambas as concentrações da vitamina 
citadas. Para cada um destes volumes de lodo utilizados, foram preparados e incubados frascos em duplicata.

No Bioensaio 2, como o ácido fólico é uma substância de baixa solubilidade, foi empregada uma das alternativa apresentadas pelo Merck Index (2001) para aumentar a solubilidade do mesmo e possibilitar sua dissolução - ou seja, a solução foi preparada em água destilada fervente. Neste ensaio testou-se as concentrações 2,5 e 4,0 mg/L de ácido fólico. Foram utilizados os volumes de lodo 0,$1 ; 0,3 ; 0,5 ; 1,0$ e 1,5 ml para ambas as concentrações de ácido fólico testadas, sendo que foram preparados frascos em duplicata para cada um destes volumes.

No Bioensaio 3, o consumo de OD nos frascos foi quantificado diariamente durante o período do ensaio, retirando da incubadora de $\mathrm{DBO}\left(20^{\circ} \mathrm{C}\right)$ um frasco das cinco réplicas de cada concentração de ácido fólico, e determinado o OD residual. Cada frasco retirado da incubação e lido era descartado. Neste terceiro ensaio, bem como nos Bioensaios 4 e 5, o ácido fólico foi previamente dissolvido em solução de bicarbonato de sódio, na proporção 1:1 (100mg de ácido fólico e 100mg de bicarbonato de sódio diluídos em 1 litro de água destilada), segundo recomendação apresentada na referência Merck Index (2001) para dissolução do mesmo. Tal como no Bioensaio 2, foram preparados frascos de DBO com as soluções nutritivas e com a introdução das concentrações $2,5 \mathrm{mg} / \mathrm{L} \mathrm{e}$ 4,0 mg/L de ácido fólico, e frascos controle (sem adição desta vitamina). O volume de lodo introduzido em todos os frascos como inóculo foi de $0,5 \mathrm{ml}$.

No Bioensaio 4, as concentrações de ácido fólico utilizadas foram 0,5; 2,5 e 4,0 mg/L, e a quantidade de lodo inoculado em cada frasco foi de $0,5 \mathrm{ml}$. 
No Bioensaio 5, foram também feitas medições diárias de OD e o volume de lodo utilizado foi de $0,5 \mathrm{ml}$. A única concentração de ácido fólico testada foi de $2,5 \mathrm{mg} / \mathrm{L}$, e o diferencial deste ensaio foi o teste adicional da solução comercial, para comparação.

\subsubsection{Preparo da solução de ácido fólico e de Dosfolat}

Para a preparação da solução de ácido fólico, empregou-se uma solução estoque, diluindo $100 \mathrm{mg}$ desta vitamina em $1000 \mathrm{ml}$ de água destilada, sendo o frasco contendo a solução armazenado protegido da luz, para evitar a foto-oxidação da mesma.

$\mathrm{O}$ volume desta solução inserido nos frascos de $\mathrm{DBO}$, para que fossem equivalentes às concentrações de ácido fólico estabelecidas, foi calculado proporcionalmente pelo volume padronizado de $300 \mathrm{~mL}$, que corresponde à média dos volumes destes frascos. Desta forma, determinou-se os volumes para cada concentração testada através do cálculo:

$$
\mathrm{C}_{1} \times \mathrm{V}_{1}=\mathrm{C}_{2} \times \mathrm{V}_{2} \text {, onde: }
$$

- $\mathrm{C}_{1}$ = massa de ácido fólico em pó, diluído em 1 litro de água destilada;

- $\mathrm{V}_{1}=$ volume $(\mathrm{ml})$ da solução de ácido fólico a ser introduzido em cada frasco;

- $\mathrm{C}_{2}=$ concentração de ácido fólico nos frascos;

- $\mathrm{V}_{2}=$ volume médio dos frascos de $\mathrm{DBO}$.

Tendo-se assim: $100 \mathrm{mg} / \mathrm{L}$ x V = C mg/L x $300 \mathrm{ml}$. 
Desta forma, os volumes de ácido fólico adicionados nos frascos, equivalentes às concentrações estabelecidas nos bioensaios, estão apresentadas na Tabela 8.

\begin{tabular}{cc}
$\begin{array}{c}\text { TABELA } 8 \text { - CONCENTRAÇÕES DE ÁCIDO FÓLICO E OS VOLUMES DE } \\
\text { SOLUÇÃO EQUIVALENTES }\end{array}$ \\
\hline $\begin{array}{c}\text { CONCENTRAÇÃO DE } \\
\text { AOLUME DE SOLUÇÃO DE } \\
\text { ÁCIDO FÓLICO }(\mathrm{mg} / \mathrm{L})\end{array}$ \\
\hline 0,5 & 1,5 \\
1,0 & 3,0 \\
2,0 & 6,0 \\
2,5 & 7,5 \\
4,0 & 12 \\
\hline
\end{tabular}

A solução de Dosfolat, testada no Bioensaio 5, foi preparada a partir de solução estoque, diluindo 1 g deste em 200 ml de água destilada, com concentração de 5 g/L. Foi estabelecida a aplicação da dosagem de $2,5 \mathrm{mg} / \mathrm{L}$ de Dosfolat, sendo desta forma adicionado o volume de 7,5 mL desta solução nos frascos de $300 \mathrm{~mL}$.

\subsubsection{Exames microscópicos de caracterização das amostras de lodo usadas nos bioensaios}

As amostras de lodo utilizado como inóculo nos bioensaios foram submetidas a exame de microscopia, tendo como objetivo avaliar qualitativamente a amostra de lodo, através de observação das características morfológicas e estruturais dos flocos, abundância relativa de organismos filamentosos, organismos componentes da microfauna, ocorrência de predominância de determinado organismo ou grupo sobre os demais e a presença de células livres em suspensão. 
Os aspectos analisados foram registrados por fotomicrografias tiradas por uma máquina fotográfica acoplada à trinocular do microscópio óptico Nikon, Câmera Nikon - Microflex PFX, modelo FX-35W (Figura 10), sob iluminação de campo claro e contraste de fase nas magnitudes de 40 vezes (ocular 10, objetiva 4) e 100 vezes (ocular 10, objetiva 10) de aumento. Foi utilizado filme em cores de $35 \mathrm{~mm}$, qualidade ISO 400, da marca Kodak, tipo Ultra. Este microscópio também foi utilizado no monitoramento do ensaio de reatores em batelada, posteriormente realizado.

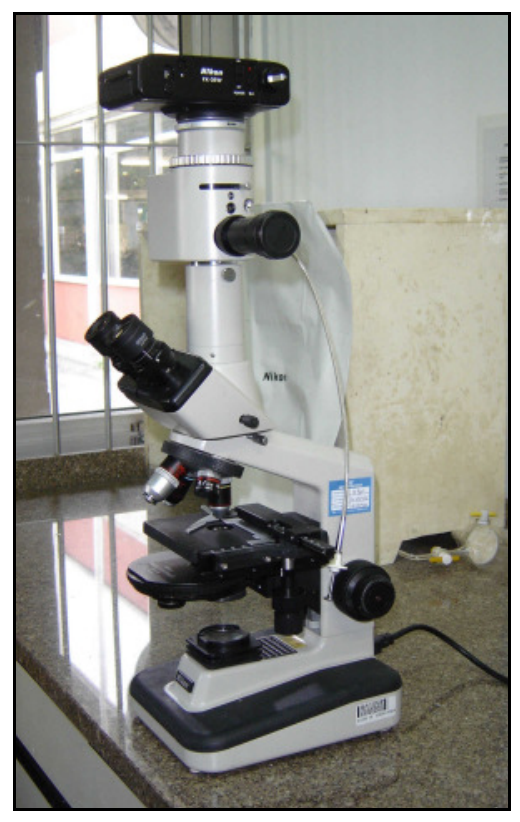

Figura 10 - Vista do microscópio óptico de contraste de fase utilizado

As observações feitas através do exame microscópico qualitativo, bem como as fotomicrografias registradas estão apresentadas nos resultados desta dissertação. 


\subsection{Ensaio em reatores em batelada}

\subsubsection{Descrição do ensaio}

Foi realizado ensaio em reatores simulando processo de lodos ativados, de vazão intermitente (em batelada). Neste foram utilizados três reatores biológicos, com características idênticas, cada um apresentando uma condição diferente - um com adição de solução de ácido fólico, um com adição de solução de Dosfolat e outro controle, para se avaliar a influência da adição destas soluções na composição da microbiota e na eficiência do tratamento.

Os reatores foram construídos em acrílico, cada um apresentando volume útil de $0,025 \mathrm{~m}^{3}$, área superficial de $0,0625 \mathrm{~m}^{2}$, tendo $0,25 \mathrm{~m}$ de largura, $0,25 \mathrm{~m}$ de comprimento e 0,40 m de altura. Este sistema de reatores foi instalado no Laboratório de Saneamento "Prof. Lucas Nogueira Garcez", do Departamento de Engenharia Hidráulica e Sanitária da Escola Politécnica da USP, e estão ilustrados na Figura 11 e apresentados nas Figuras 12 e 13.

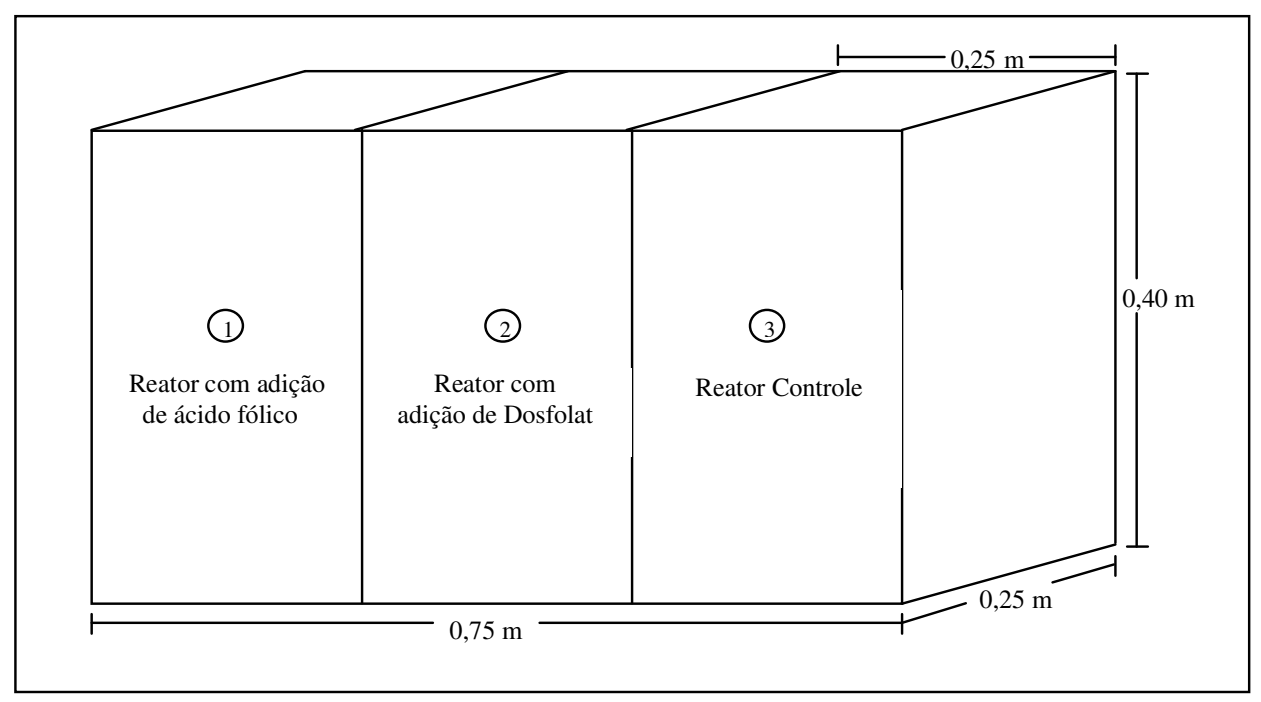

Figura 11 - Esquema representativo dos reatores de lodos ativados e suas dimensões 


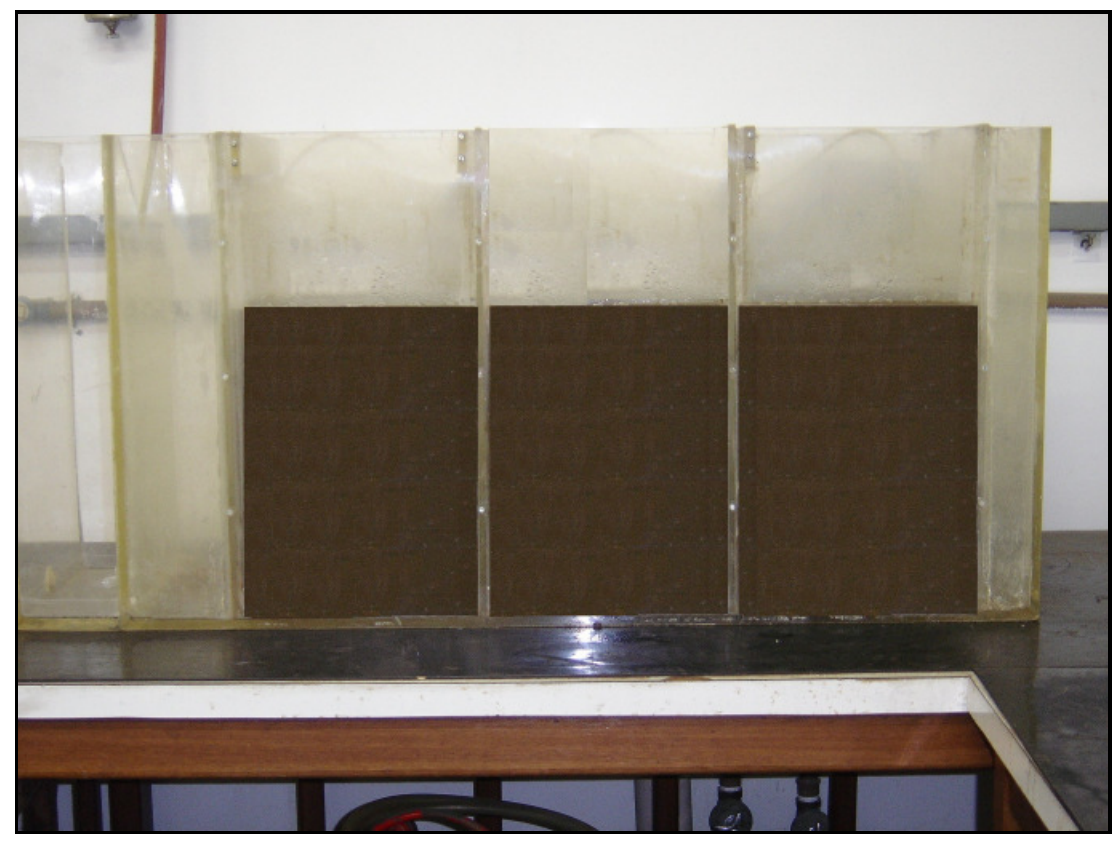

Figura 12 - Vista frontal do sistema de reatores de lodos ativados, instalados em bancada, em ciclo de aeração e mistura da massa líquida, pelos aeradores ligados

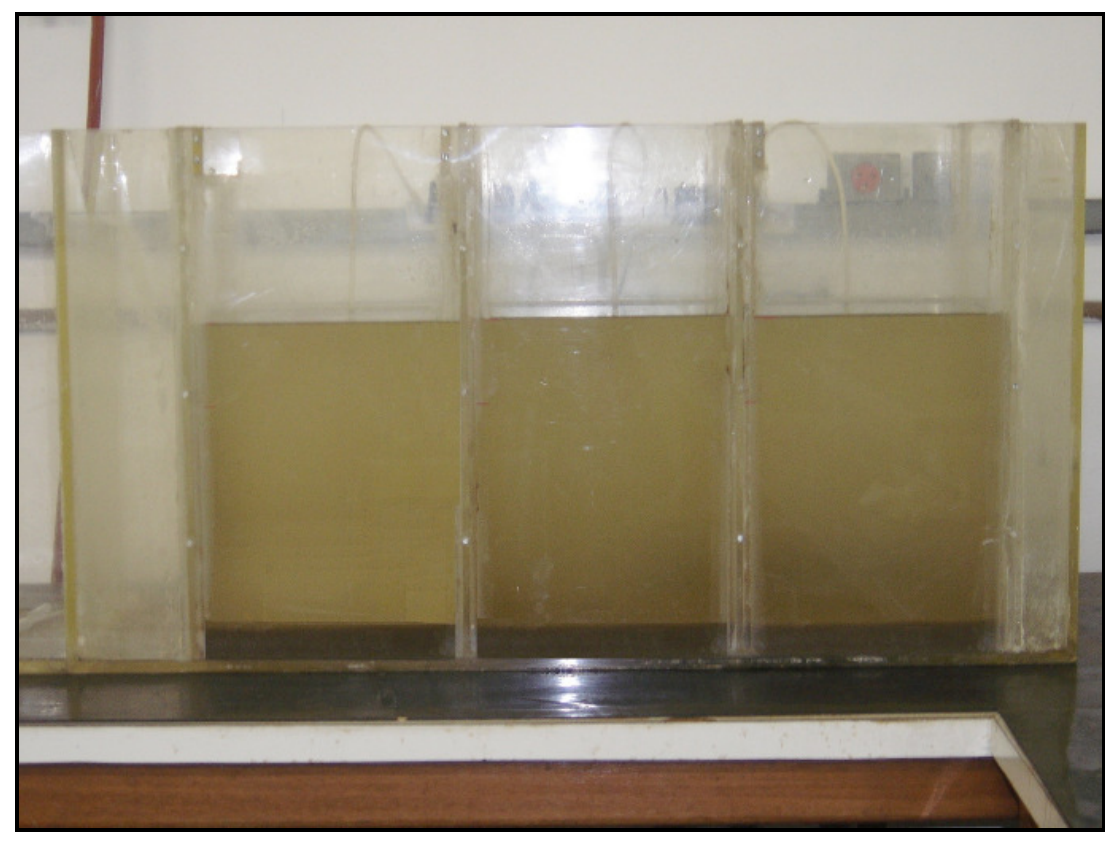

Figura 13 - Vista dos reatores com aeradores desligados, para descarte do efluente tratado (sobrenadante) 
A inoculação dos reatores foi efetuada com lodo proveniente do tanque de aeração da estação de tratamento de lodos ativados da ETE ABC, sendo a mesma origem do inóculo utilizado nos bioensaios de DBO. Com relação às proporções de inóculo introduzido nos reatores para dar partida no sistemas, foi estabelecido o volume de 7 litros de lodo em cada reator, coletados na linha de retorno desta estação, sendo posteriormente adicionados 13 litros de água para diluir o lodo, e assim completar o volume de reação de 20 litros.

A partir do início da operação dos reatores, deixou-se transcorrer um período de 60 dias com condições contínuas de alimentação para que ocorresse o estabelecimento da cultura microbiana típica de lodos ativados, após o qual acresceram-se as soluções de ácido fólico e de Dosfolat. O período contínuo visou garantir estabilidade dos sistemas. Assim, após o período de adaptação da biomassa e estabilidade dos reatores, os reatores foram monitorados através de exames microscópicos e determinações físico-químicas por mais um período de 60 dias, sendo mantida a idade do lodo de 25 dias.

A aeração dos reatores foi efetuada por sistema de ar difuso, utilizando compressor de ar, que por meio de um diafragma interno promoveu a entrada de oxigênio através de pedra porosa (difusor de ar), fixado no fundo do reator, como ilustrado na Figura 14. Foram instalados compressores de ar idênticos em cada reator (marca Vigoar), cada um com uma saída e vazão de capacidade para aeração de 60 litros. A aeração efetuada através de bolhas de ar médias produzidas pelo compressor também promoveu a mistura do lodo nos reatores, com o fim de mistura completa, sendo conseqüentemente mantida uma elevada concentração de oxigênio dissolvido, em torno de $6 \mathrm{mg} \mathrm{O}_{2} / \mathrm{L}$, para fazer a mistura satisfatoriamente. 


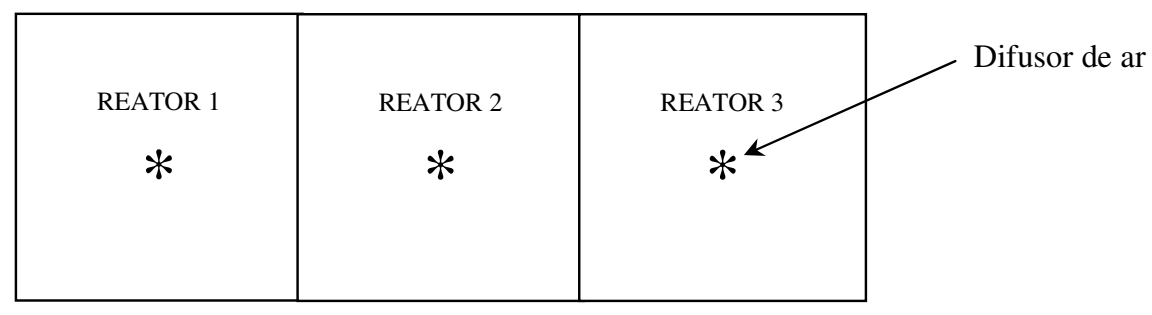

Figura 14. Representação esquemática da planta dos reatores em batelada, e os difusores instalados

Quando deu-se início a aplicação de soluções de ácido fólico e de Dosfolat nos reatores, as paredes destes foram envolvidas em papel kraft, a fim de protegê-los da luz e assim minimizar a foto-oxidação da vitamina das soluções adicionadas ao lodo.

\subsubsection{Alimentação dos reatores}

A alimentação dos reatores foi feita diariamente em batelada, com substrato sintético com constituintes orgânicos e inorgânicos simulando as características nutritivas do esgoto sanitário, cuja vazão de alimentação de cada reator correspondia ao volume de lodo descartado. Esta era realizada sempre no período da manhã, entre 8:00 e 9:00 h.

O substrato sintético empregado apresenta composição recomendada pela EPA*, cuja constituição está apresentada na Tabela 9. Esta solução, preparada com 1 litro de água destilada, é uma solução estoque concentrada, sendo constituída de vitaminas, proteínas, carboidratos, sais minerais.

\footnotetext{
* EPA - Environmental Protection Agency. Ecological Effects Test Guidelines. Modified Activated Sludge, Respiration Inhibition Test for Sparingly Soluble Chemicals. United States: 1996.
} 
A solução preparada apresentava pH entre 7 e 8, e segundo a referência utilizada, deve ser preparada para o período máximo de uma semana de operação, e devendo ser acondicionada sob refrigeração, à temperatura $20 \pm 2^{\circ} \mathrm{C}$.

TABELA 9 - COMPOSIÇÃO DO SUBSTRATO SINTÉTICO SIMULANDO ESGOTO SANITÁRIO

\begin{tabular}{lcc}
\hline \multicolumn{1}{c}{ CONSTITUINTE } & DESCRIÇÃO & $\begin{array}{c}\text { CONCEN- } \\
\text { TRAÇÃ } \\
(\mathrm{g} / \mathrm{L})\end{array}$ \\
\hline Peptona $^{1}$ & $\begin{array}{c}\text { Proteínas, } \mathrm{N}_{\text {org }} \text { e vitaminas } \\
\text { Compostos de } \mathrm{N}_{\text {org }} \text {, vitaminas, } \\
\text { carboidratos e sais }\end{array}$ & 16 \\
Extrato de carne & & 11 \\
Uréia $\left(\mathrm{NH}_{2} \mathrm{CONH}_{2}\right)$ & - & 3 \\
Cloreto de sódio $(\mathrm{NaCl})$ & Sais minerais & 0,7 \\
Cloreto de cálcio dihidratado $\left(\mathrm{CaCl}_{2} \cdot 2 \mathrm{H}_{2} \mathrm{O}\right)$ & Sais minerais & 0,4 \\
Sulfato de magnésio pentahidratado $\left(\mathrm{MgSO}_{4} \cdot 7 \mathrm{H}_{2} \mathrm{O}\right)$ & Sais minerais & 0,2 \\
Fosfato de potássio monobásico anidro $\left(\mathrm{K}_{2} \mathrm{HPO}_{4}\right)$ & Tampão e íons essenciais & 2,8 \\
\hline
\end{tabular}

FONTE: EPA (1996)*

NOTA: (1) Enzima digestiva pancreática de caseína; (2) Extrato de carne bovina desidratada. Ambos são utilizados para o preparo de culturas microbiológicas

Para a alimentação de cada reator foi preparado o efluente sintético a partir desta solução, diluindo-se $100 \mathrm{ml}$ em 5 litros de água destilada (diluição de 50 vezes). Assim, diariamente eram preparados 15 litros de substrato para alimentar em batelada os reatores. Como cada solução estoque apresentava 1 litro, e eram utilizados diariamente $300 \mathrm{ml}$ da mesma para alimentar os três reatores, era possível efetuar as diluições para o preparo de efluente por três dias consecutivos. Desta forma, a solução estoque foi preparada duas vezes por semana durante o período do ensaio. Os valores de DQO e DBO do esgoto sintético diluído como descrito, foram respectivamente $713 \mathrm{mg} / \mathrm{L} \mathrm{e} 269 \mathrm{mg} / \mathrm{L}$.

Para a operação do sistema em batelada com 25 dias de idade do lodo, o efluente descartado diariamente foi $25 \%$ do volume do reator - 5 litros, nos quais eram descartados $21 \%$ do sobrenadante $(4,2$ L, após um período de 40 minutos com a aeração dos reatores 
interrompida para ocorrer a sedimentação dos sólidos) e $4 \%$ do lodo $(0,8 \mathrm{~L})$. O descarte era feito manualmente, através da utilização de uma bomba de sucção, em que estes volumes eram transferidos para bombonas de plástico e em seguida descartados.

\subsubsection{Soluções de ácido fólico e de Dosfolat aplicadas nos reatores}

As soluções de ácido fólico e de Dosfolat introduzidas rotineiramente nos reatores foram preparadas a cada dois dias, para garantir a estabilidade das soluções e evitar a fotooxidação das mesmas. Ambas as soluções foram aplicadas também em batelada diariamente, sendo introduzidas após a alimentação dos reatores com esgoto sintético.

Para preparar a solução de ácido fólico a ser adicionada nos reatores, tal como nos bioensaios de respirometria, foi feita solução estoque diluindo $100 \mathrm{mg}$ de ácido fólico e 100 mg de bicarbonato de sódio em 1 litro de água destilada. Ressalta-se que este último foi utilizado para aumentar a solubilidade do ácido fólico. Assim, foi estabelecido um período de adição de dosagem de choque de ácido fólico, durante os primeiros 7 dias, com a concentração $10 \mathrm{mg} / \mathrm{L}$, sendo adicionados diariamente $100 \mathrm{ml}$ de solução, enquanto que a dosagem para operação contínua após este período foi de $2,5 \mathrm{mg} / \mathrm{L}$, sendo adicionado o volume $25 \mathrm{ml}$.

Para o preparo da solução de Dosfolat, diluiu-se este composto em água destilada na proporção 1:200, desta forma, foi preparada uma solução estoque de 1 g de Dosfolat em 200 ml de água destilada (concentração de $5 \mathrm{~g} / \mathrm{L}$ ). As concentrações de Dosfolat a serem aplicadas 
no reator foram estabelecidas segundo recomendações do fabricante deste composto para o preparo e aplicação desta solução em reatores de estações de tratamento de águas residuárias, sendo baseado na vazão de alimentação do tanque de aeração, sendo neste caso considerada a vazão de 5 litros. Inicialmente, durante os 7 primeiros dias, foi adicionada uma dosagem de choque de $5 \mathrm{~g} / \mathrm{L}$, cujo volume de solução de Dosfolat introduzido diariamente em batelada foi de 2,0 mL, e após este período, o composto foi adicionado em menor concentração - 1,25 $\mathrm{mg} / \mathrm{L}$, em dosagem contínua, com o volume de $0,5 \mathrm{~mL}$.

\subsubsection{Análises de monitoramento}

Os reatores foram monitorados rotineiramente para controle operacional do processo, observando os parâmetros pH, temperatura e concentração de oxigênio dissolvido. Outro parâmetro observado no controle do processo foi nitrato $\left(\mathrm{NO}_{3}{ }^{-}\right)$, para avaliar-se a eficiência da remoção de matéria nitrogenada através da nitrificação. Em relação ao monitoramento do pH do lodo, quando este estava inferior a 6,5, era adicionada solução de bicarbonato de sódio, até pH 7 e assim aumentar a capacidade tampão do reator.

Para avaliar o desempenho do processo de tratamento, foi realizado monitoramento através de análises dos parâmetros físico-químicos, especialmente quanto à remoção de matéria orgânica e de sólidos em suspensão, a fim de correlacionar os resultados das análises destes parâmetros com os microrganismos presentes nos sistemas. Os parâmetros físicoquímicos e biológicos analisados para o monitoramento dos reatores, bem como a periodicidade e os pontos de amostragens, estão apresentados na Tabela 10. 


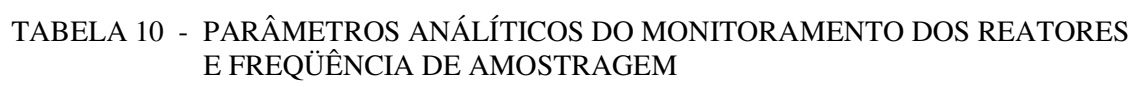

\begin{tabular}{lcc}
\hline \multicolumn{1}{c}{ PARÂMETRO } & AMOSTRA $^{(1)}$ & $\begin{array}{c}\text { FREQÜÊNCIA } \\
\text { SEMANAL }\end{array}$ \\
\hline Exame microscópico & $\mathrm{L}$ & $3 \mathrm{x}$ \\
$\mathrm{pH}$ & $\mathrm{L}$ & diária \\
Sólidos em Suspensão (SST, SSV, SSF) & $\mathrm{L}, \mathrm{E}$ & $3 \mathrm{x}$ \\
Demanda Bioquímica de Oxigênio (DBO) & $\mathrm{E}$ & $1 \mathrm{x}$ \\
Demanda Química de Oxigênio (DQO) & $\mathrm{E}$ & $2 \mathrm{x}$ \\
Índice Volumétrico de Lodo (IVL) & $\mathrm{L}$ & $3 \mathrm{x}$ \\
Nitrato & $\mathrm{E}$ & $3 \mathrm{x}$ \\
\hline
\end{tabular}

NOTA: (1) Ponto de amostragem de cada reator: L - lodo; E - efluente final (sobrenadante)

Para avaliar o comportamento microbiano dos reatores, foram efetuados exames microscópicos qualitativos, com amostras "in vivo", em que foram observadas as características dos flocos; a diversidade da microfauna presente; a abundância relativa das filamentosas e o aspecto geral do lodo. Também foram fixadas amostras em lâminas de vidro para microscopia, para aplicação de técnicas de coloração para identificação de filamentosas. A metodologia para a identificação de filamentosas e caracterização microscópica está descrita no item 4.3.4.2. desta dissertação. As amostras examinadas microscopicamente foram registradas fotomicrograficamente, com a utilização de máquina fotográfica acoplada ao microscópio óptico, sendo já descrito no item 4.2.4.

Todas as análises e determinações físico-químicas foram realizadas no Laboratório de Saneamento "Professor Lucas Nogueira Garcez", que dispunha de todos os equipamentos e reagentes necessários à execução das mesmas. Os procedimentos de análises seguiram os descritos pelo "Standard methods for examination of water and wastewater", $20^{\mathrm{a} e d .}$ (APHA, 1998), cujos métodos analíticos empregados estão descritos a seguir. 
- $\mathrm{pH}$ : Método potenciométrico com eletrodo de $\mathrm{pH}$ (pHmetro). Unidade de laboratório e unidade portátil carregada com bateria.

- Sólidos em Suspensão Totais, Fixos e Voláteis: Sólidos em suspensão totais são determinados por filtração em filtro-membrana de fibra de vidro de $1,2 \mu \mathrm{m}$ e secagem em estufa a $104^{\circ} \mathrm{C}$. Sólidos em Suspensão Fixos: Calcinação da membrana após filtração e secagem em forno mufla a $550-600^{\circ} \mathrm{C}$. E os sólidos em Suspensão Voláteis são determinados pelo cálculo da diferença entre sólidos em suspensão totais e os fixos.

- Demanda Bioquímica de Oxigênio $\left(\mathrm{DBO}_{5,20}\right)$ : Técnica das diluições sem semeadura e incubação a $20^{\circ} \mathrm{C}$. Determinação de concentrações de oxigênio dissolvido pelo método eletrométrico e alternativo pelo Método de Winkler modificado pela azida de sódio (Iodometria).

- Demanda Química de Oxigênio (DQO): Método convencional de oxidação química com dicromato de potássio catalisada pela prata em refluxo aberto. Titulação do excesso de dicromato com sulfato ferroso amoniacal.

- Índice Volumétrico de Lodo (IVL): Medida que consiste em decantação de 1 litro de lodo em proveta após 30 minutos, em que se determina o volume ocupado pelo lodo após este período. O cálculo é realizado a partir deste volume e em função da determinação da concentração de sólidos em suspensão.

- Nitrato: Redução química de nitrato a nitrito em coluna de cádmio e colorimetria com sulfanilamida com leituras de absrobância em espectrofotômetro UV-visível. 


\subsubsection{Exame qualitativo da microfauna}

Para as verificações microbiológicas, as amostras dos reatores de lodos ativados foram examinadas sob microscopia óptica diariamente, para análise qualitativa da microfauna presente. Neste exame qualitativo, foi realizada identificação simplificada, uma vez que a determinação de todas as espécies presentes é complexa de ser realizada num trabalho de monitoramento. Assim, foi feita identificação da microfauna distribuída em classes (grandes grupos): ciliados livres, ciliados fixos, rizópodes, flagelados, rotíferos, tardigrados, anelídeos e nematóides. Os organismos de ocorrência mais comum e de identificação mais simples foram identificados no nível de gênero.

Para a identificação dos organismos componentes da microfauna, foram utilizadas as seguintes literaturas: "Manual on The Causes and Control of Activated Sludge Bulking, Foaming and Other Solids Separation Problems" (Jenkins et al., 2004); "Microscopic Sludge Investigation Manual" (Eikelboom \& Buijsen, 1981); "Wastewater Organisms - A Color Atlas" (Berk \& Gunderson, 1993) e "Microbiologia de Lodos Ativados" (Vazoller, 1989).

Os exames microscópicos foram efetuados imediatamente após a coleta, uma vez que a análise deve ser realizada "in vivo", para evitar alterações na composição da microfauna, não sendo utilizados conservantes químicos. As amostras para exames microscópicos foram coletadas em frascos preenchidos até a metade de seu volume, a fim de manter-se a amostra aerada, importante à sobrevivência da microbiota. Quando não foi possível realizar exames imediatos, as amostras foram mantidas sob refrigeração a $4^{\circ} \mathrm{C}$, não ultrapassando um período de 6 horas. 
Com a utilização de uma pipeta Pasteur, uma gota de cada amostra era transferida em lâmina para microscopia, cobrindo-a posteriormente com lamínula, evitando-se a formação de bolhas. O exame foi feito em microscópio óptico (descrito no item 4.2.4.), nas magnitudes de aumento de 100 vezes (ocular 10, objetiva 10) e de 400 vezes (ocular 10, objetiva 40).

No exame completo de microscopia, além da análise qualitativa do lodo, foi realizada fixação das amostras em lâminas para a aplicação de técnicas de coloração para identificação de bactérias filamentosas. Os exames foram feitos em triplicata, ou seja, foram preparadas três lâminas de cada amostra, em que foram observados os seguintes aspectos:

- Avaliação qualitativa das populações da microbiota presentes reatores e acompanhamento de possíveis variações da diversidade populacional nos reatores em que foi aplicado ácido fólico;

- Ocorrência de determinado grupo ou gênero predominante sobre os demais componentes da microbiota do lodo;

- Avaliação da proporção de bactérias filamentosas presentes;

- Características e tamanhos dos flocos biológicos presentes no lodo;

- Acompanhamento da interferência do ácido fólico sobre a dinâmica e o crescimento populacional da microbiota, bem como avaliar a diversidade nos reatores;

- Se os organismos apresentavam-se ativos.

Para as determinações do diâmetro dos flocos e do comprimento dos filamentos foram feitas utilizando a câmara de Sedgwick-Rafter, mostrada na Figura 15, que é usada em contagens de protozoários, bactérias filamentosas, micrometazoários e flocos. A câmara tem 
capacidade de $1 \mathrm{ml}$, com as dimensões $50 \mathrm{~mm}$ de comprimento, $20 \mathrm{~mm}$ de largura e $1 \mathrm{~mm}$ de altura, sendo dividida em campos. Deve-se completar o volume da câmara, inserindo amostra líquida com uma pipeta, por um lado da câmara e permitindo que o ar saia o lado oposto, como representado na Figura 16. Antes do início da contagem, a câmara era deixada em repouso por 5 minutos para que a amostra sedimentasse.

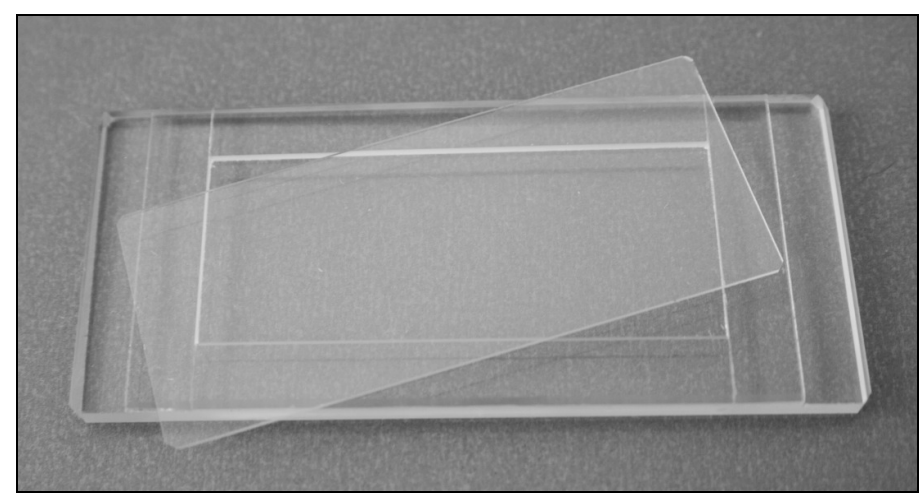

Figura 15 - Vista da câmara de contagem de Sedgwick-Rafter

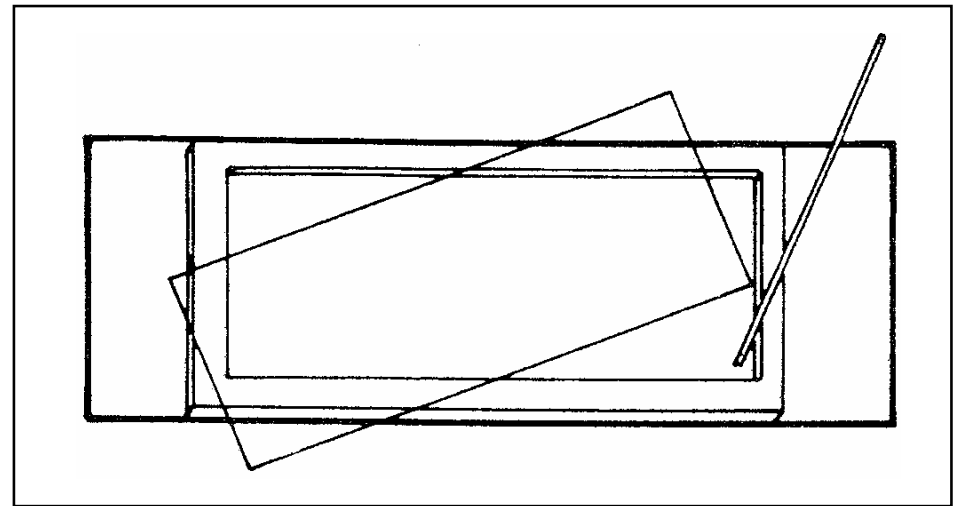

Figura 16 - Ilustração da câmara de Sedgwick-Rafter, mostrando a forma de se colocar a amostra com pipeta (Fonte: Vazoller, 1989)

As metodologias para as determinações do diâmetro dos flocos e do comprimento dos filamentos, apresentadas por Vazoller (1989) e por Villas Bôas (1996) apud Jenkins et al. (1993), estão descritos a seguir. 
Os diâmetros dos flocos foram determinados através do procedimento:

a) As amostras eram primeiramente diluídas - com uma pipeta de boca larga transferiuse $2 \mathrm{~mL}$ de amostra de lodo ativado homogeneizada para um becker de $2 \mathrm{~L}$, contendo 1 L de água destilada. A seguir, foi efetuada a homogeneização por agitação manual com um bastão de vidro durante um minuto;

b) Alíquotas da amostra diluída eram inseridas na Câmara de Sedgwick-Rafter, e examinadas ao microscópio na magnitude de 200 vezes, sendo medidos o diâmetro de 20 flocos. Nos flocos de forma irregular, foi considerado o maior diâmetro, e não foram considerados os filamentos ligados a estes;

c) Posteriormente, calculou-se a média dos diâmetros dos flocos.

Para determinação do comprimento dos filamentos foi realizado o procedimento:

a) Foi efetuado o mesmo procedimento de diluição das amostras para determinação do diâmetro dos flocos;

b) Em seguida, transferiu-se $1 \mathrm{~mL}$ desta amostra diluída para a Câmara de SedgwickRafter, e mediu-se os comprimentos dos filamentos existentes através do retículo de Whipple do microscópio, percorrendo toda a lâmina. Ao microscópio, na magnitudes de 200 vezes, considerou-se os filamentos ligados aos flocos, os com crescimento epifítico e os livres;

c) O cálculo foi feito de acordo com a fórmula:

$$
\text { C.F. }=\mathrm{A} \times \mathrm{F}
$$


Onde:

C.F. - comprimento do filamento $(\mu \mathrm{m} / \mathrm{mL})$

A - somatória do comprimento dos filamentos observados na câmara $(\mu \mathrm{m})$

F - fator de diluição (500)

Para orientar o exame microscópico completo, com a observação destes aspectos, foi elaborado um formulário prático para ser utilizado como roteiro de análise, baseado nas descrições citadas nas literaturas sobre identificação e caracterização microbiológica do lodo, sendo apresentado nas Figuras 17 e 18. 
Figura 17 - Formulário para exame microscópico (pag.1/2)

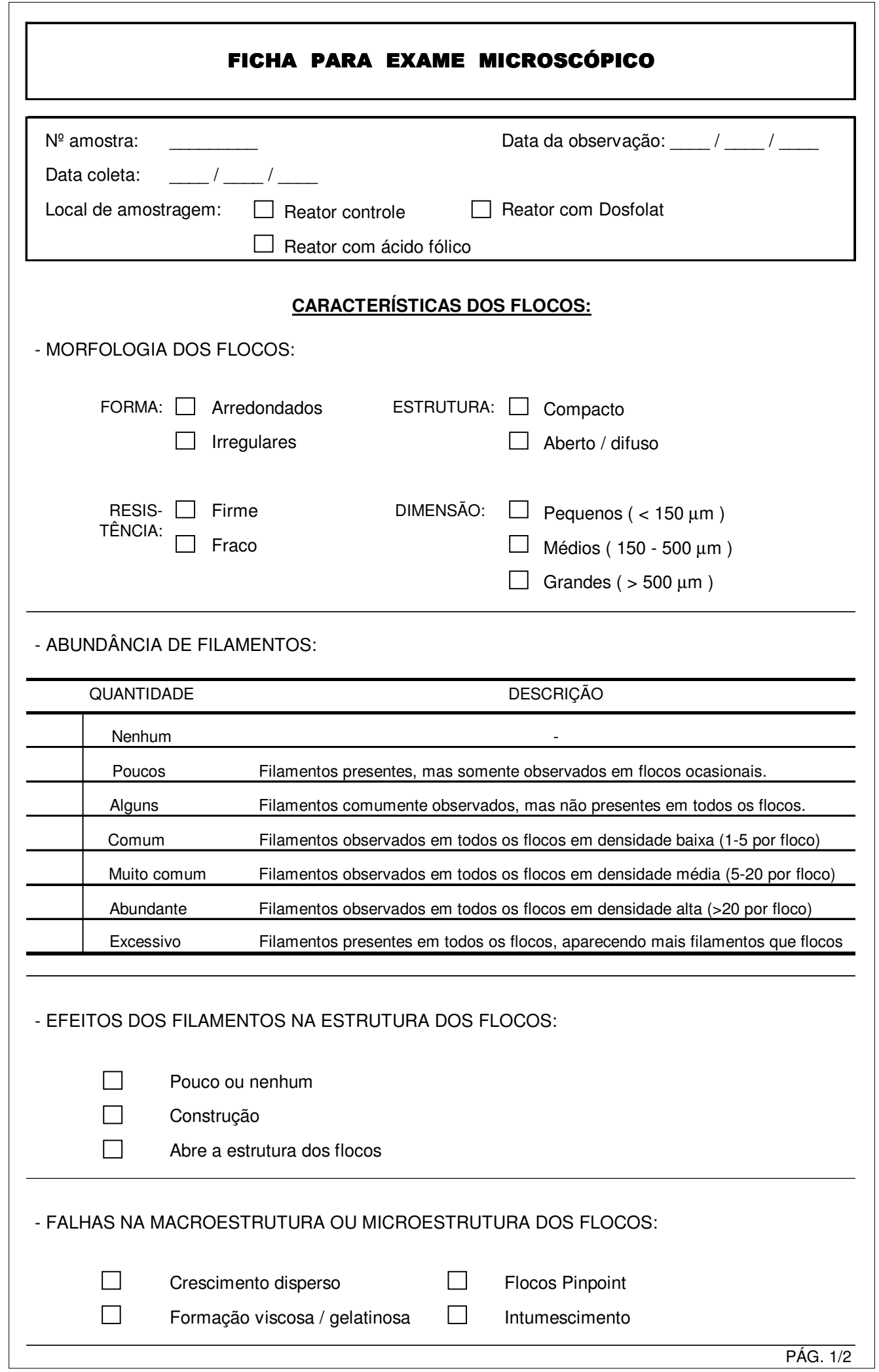


Figura 18 - Formulário para exame microscópico (pag.2/2)

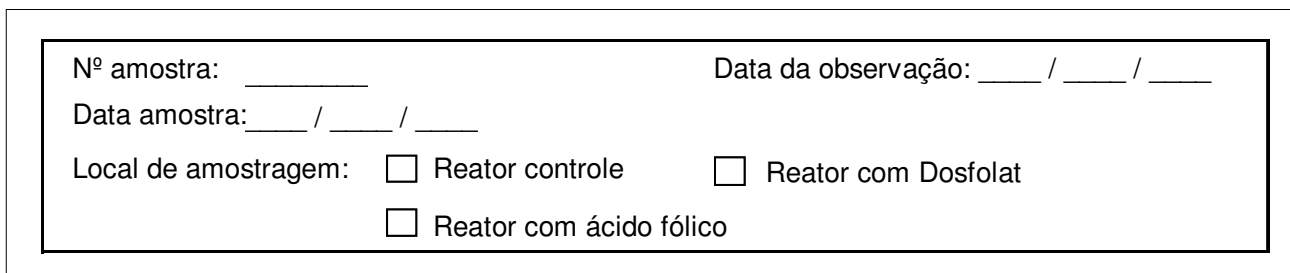

ANÁLISE DA MICROBIOTA :

- PRESENÇA E IDENTIFICAÇÃO DOS ORGANISMOS:

\begin{tabular}{|c|c|c|c|}
\hline PROTOZOÁRIOS & \multicolumn{3}{|c|}{ GÊNERO ENCONTRADO } \\
\hline ciliados livre-natantes & $\begin{array}{l}\square \text { Paramecium } \\
\square \text { Chilodonella }\end{array}$ & $\begin{array}{l}\square \text { Litonotus } \\
\square \text { Colpidium }\end{array}$ & $\begin{array}{l}\square \text { Amphileptus } \\
\square \text { Outros:.................. }\end{array}$ \\
\hline ciliados pedunculados & $\begin{array}{l}\square \text { Vorticella } \\
\square \text { Opercularia }\end{array}$ & $\begin{array}{l}\square \text { Epistylis } \\
\square \text { Carchesium }\end{array}$ & $\begin{array}{l}\square \text { Podophrya } \\
\square \text { Outros:................ }\end{array}$ \\
\hline $\begin{array}{l}\text { ciliados livres, predadores } \\
\text { de flocos }\end{array}$ & $\begin{array}{l}\square \text { Aspidisca } \\
\square \text { Euplotes }\end{array}$ & $\begin{array}{l}\square \text { Stylonychia } \\
\square \text { Oxytricha }\end{array}$ & 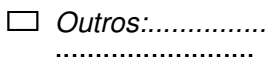 \\
\hline flagelados & $\begin{array}{l}\square \text { Bodo } \\
\square \text { Cercobodo }\end{array}$ & $\begin{array}{l}\square \text { Mona } \\
\square \text { Euglena }\end{array}$ & $\begin{array}{l}\square \text { Trigonomonas } \\
\square \text { Outros:................ }\end{array}$ \\
\hline rizópodes & $\begin{array}{l}\square \text { Amoeba } \\
\square \text { Arcella }\end{array}$ & $\begin{array}{l}\square \text { Actinophrys } \\
\square \text { Difflugia }\end{array}$ & $\begin{array}{l}\square \text { Astramoeba } \\
\square \text { Outros:................ }\end{array}$ \\
\hline MICROMETAZOÁRIOS & \multicolumn{3}{|c|}{ GÊNERO ENCONTRADO } \\
\hline rotíferos & $\square$ Philodina & $\begin{array}{ll}\square \text { Rotaria } \\
\square \text { Outros:......... }\end{array}$ & 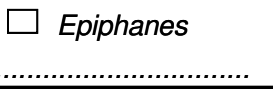 \\
\hline anelídeos & $\square$ Aelosoma & $\square$ Outros:...... & 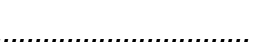 \\
\hline nematóides & $\square$ Rhabditis & $\square$ Outros:... & \\
\hline OUTROS GRUPOS & \multicolumn{3}{|c|}{ GÊNERO ENCONTRADO } \\
\hline tardígrados & $\square, \ldots \ldots \ldots \ldots \ldots$ & .......... & \\
\hline fungos & $\square \ldots \ldots \ldots \ldots \ldots$ & & \\
\hline
\end{tabular}

OUTRAS OBSERVAC̄ÕES:

- Os organismos estão vivos ? $\square$ Sim $\square$ Não

- Há células livres em suspensão ? $\square$ Sim $\square$ Não

- Há predominância de determinado grupo ou gênero sobre os demais componentes da comunidade ?

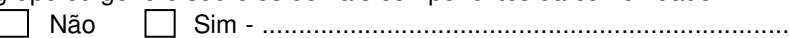

CONCLUSÕES: 


\subsubsection{Identificação de bactérias filamentosas}

A identificação de bactérias filamentosas é uma técnica relativamente simples, sendo necessária a realização de uma série de observações microscópicas, após a aplicação de testes de coloração, através dos quais é possível observar características morfológicas e estruturas das bactérias filamentosas, como forma e tamanho das células, tipo e forma do tricoma (fileira de células distintas, com grande área de contato entre estas); local do tricoma em relação ao floco; septo entre as células; presença de bainha (estrutura que envolve uma cadeia de células); tendência de crescimento epifítico (crescimento de outros microrganismos na superfície do tricoma), etc. (Jenkins et al., 1993).

Assim, foram fixadas amostras em lâminas de vidro para microscopia, de 25 x $75 \mathrm{~mm}$, sendo coletadas alíquotas das amostras de lodo com alça de platina, em seguida, cada gota retida na alça deve ser espalhada em lâmina (técnica de esfregaço). Depois, deixou-se a lâmina secar ao ar e, para assegurar a fixação do material na lâmina, a gota de amostra espalhada e seca será coberta com metanol e deixada evaporar à temperatura ambiente.

A fixação das lâminas foi feita em duplicata para cada um dos quatro tipos de técnicas de coloração, apresentadas no Item 4.3.4.2.1. desta dissertação. Em cada lâmina, foram preparados dois esfregaços, sendo um da amostra homogeneizada e outro do sobrenadante do lodo.

As observações foram registradas em formulários que foram elaborados para orientar os aspectos morfológicos que deveriam ser verificados, apresentados nas Figuras 19 e 20, para posterior análise utilizando a chave dicotômica e o quadro com as características morfológicas 
e de coloração de organismos filamentosos, elaborados por Jenkins et al. (1993), e já apresentados no Item 3.4. 
Figura 19 - Formulário para caracterização e identificação de bactérias filamentosas através de análise da amostra viva (pag.1/2)

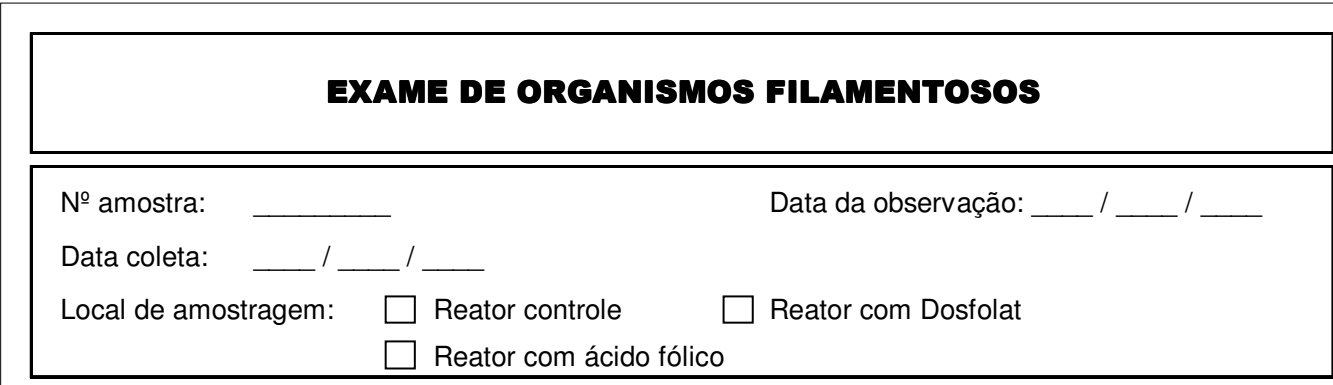

Observar o aspecto geral, percorrendo a lâmina para ver qual é a mais abundante/comum. E verificar:
$\left.1^{\circ}\right)$ Forma do filamento
3) Comprimento do filamento
$2^{\circ}$ ) Localização do filamento
4ํ) Diâmetro do filamento

OBSERVACÃO DA AMOSTRA VIVA

- Observar em aumento de 100 a $200 \mathrm{X}$ os aspectos:

\begin{tabular}{|c|c|c|c|}
\hline RAMIFICAÇÃO & $\begin{array}{l}\square \\
\square\end{array}$ & $\begin{array}{l}\text { Presente......................... } \square \text { Verdadeira } \\
\text { Ausente }\end{array}$ & $\square$ Falsa \\
\hline MOTILIDADE & $\begin{array}{l}\square \\
\square \\
\square\end{array}$ & $\begin{array}{l}\text { Deslizamento lento dos filamentos no meio } \\
\text { Contração ou oscilação } \\
\text { Sem movimento }\end{array}$ & \\
\hline FORMA DOS FILAMENTOS & $\begin{array}{l}\square \\
\square \\
\square\end{array}$ & $\begin{array}{ll}\text { Retos } & \square \text { Enrolados } \\
\text { Dobrados } & \square \text { Irregular } \\
\text { Levemente curvados } & \square \text { Micelial }\end{array}$ & \\
\hline $\begin{array}{l}\text { LOCAL DO TRICOMA EM } \\
\text { RELAÇÃO AO FLOCO }\end{array}$ & $\begin{array}{l}\square \\
\square \\
\square\end{array}$ & $\begin{array}{l}\text { Associado / ligado ao floco } \\
\text { Projetando-se do floco } \\
\text { Livre entre os flocos }\end{array}$ & \\
\hline $\begin{array}{c}\text { PRESENÇA DE } \\
\text { CRESCIMENTO EPIFÍTICO }\end{array}$ & $\square$ & $\square$ Não & \\
\hline
\end{tabular}

- Após essas observações, colocar em aumento de 1000 X, com óleo de imersão e verificar, em contraste de fase, as características dos filamentos:

\begin{tabular}{|l|l|l|}
\hline \multicolumn{2}{|l|}{ Presença de septo entre as células } & \\
\hline Presença de bainha & \\
\hline Tendência de crescimento de outros microrganismos na superfície do tricoma & \\
\hline Tipo de célula - bacilos com final & $\square$ arredondado $\quad \square$ reto $\quad \square$ discóide ou oval \\
\hline Tamanho do tricoma & $\begin{array}{l}\text { Largura/ diâmetro do filamento: ................. vm } \\
\text { Comprimento do filamento: ..................... vm }\end{array}$ \\
\hline Forma das células bacterianas & $\begin{array}{l}\square \text { quadradas } \quad \square \text { discóides } \\
\square \text { ovais }\end{array} \quad \square$ retangulares barras \\
\end{tabular}


Figura 20 - Formulário para caracterização e identificação de bactérias filamentosas através de análise de amostra fixada (pag.2/2)

\section{EXAME DE ORGANISMOS FILAMENTOSOS}

$\begin{array}{ll}\text { № amostra: } & \text { Data da observação: } \_ \text {' } \\ \text { Data coleta: } & \\ \text { Local de amostragem: } & \square \text { Reator controle } \quad \square \text { Reator com Dosfolat } \\ & \square \text { Reator com ácido fólico }\end{array}$

OBSERVACÃO DA AMOSTRA FIXADA

- Em iluminação de campo claro, com aumento de 1000X. Para a identificação de organismos filamentosos deve-s€ fazer as observações microscópicas, e em seguida usar a chave de identificação.

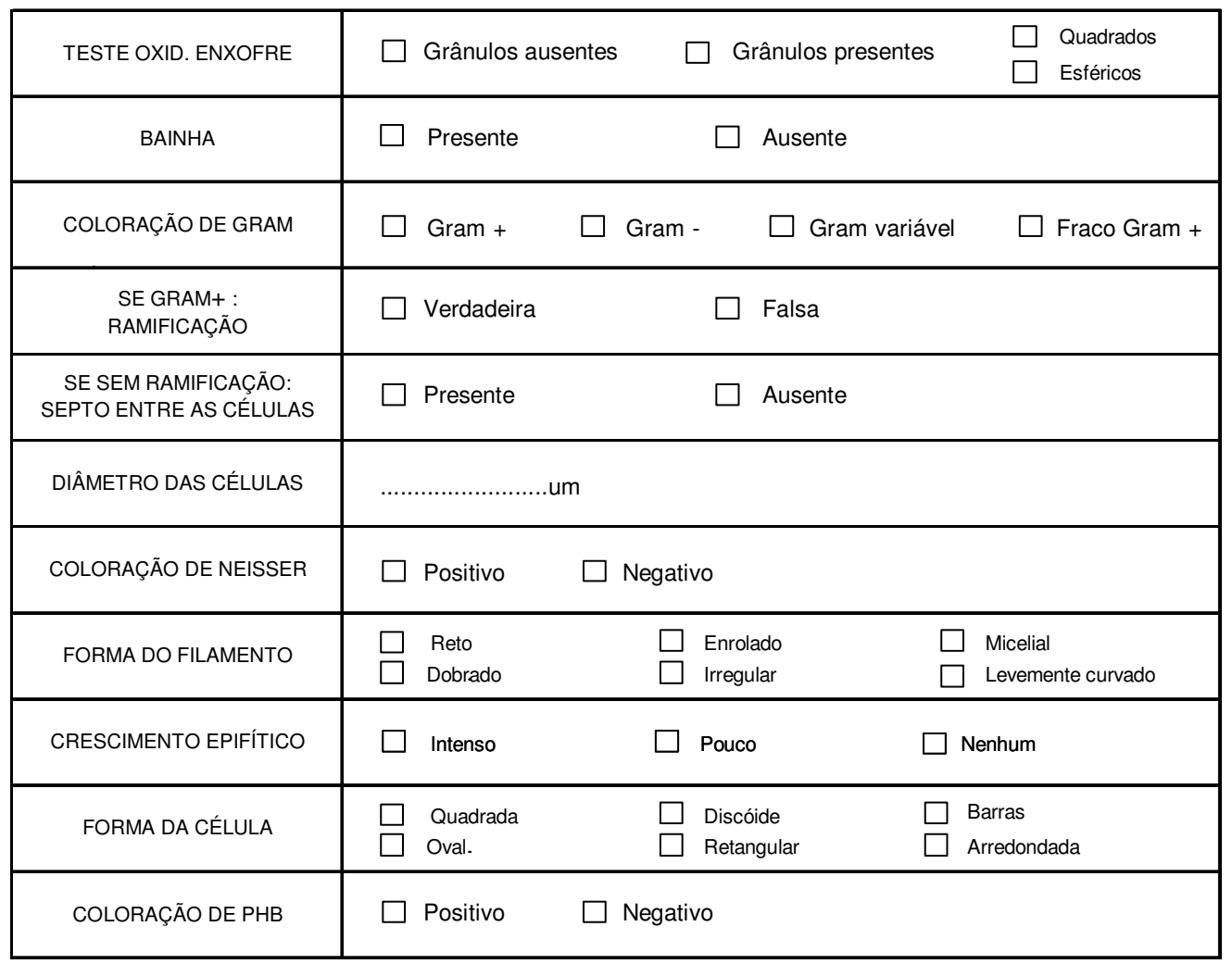

\section{RESULTADOS DAS COLORAÇÕES:}

Coloração de Gram:

- Positiva: filamento cora em roxo intenso

- Fracamente positiva: filamento cora em roxo claro

- Negativa: filamento cora em vermelho / rosa

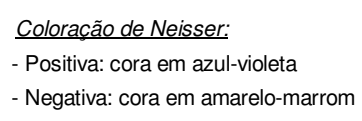

Coloração de Neisser:

- Positiva: cora em azul-violeta

- Negativa: cora em amarelo-marrom

- Variável: partes do filamento coram em roxo (+) e o restante cora em vermelho-rosado (-)
Coloração de $P H B$

Positiva: grânulos coram em azul

escuro / preto 


\subsection{Técnicas de colorações para identificação de bactérias filamentosas}

Os materiais e métodos utilizados nas técnicas de coloração para identificação de bactérias filamentosas - Gram; Neisser; coloração de polibetahidroxiburirato (PHB) e presença de grânulos de enxofre "in situ" ou teste de enxofre, estão apresentados a seguir.

\section{- ColoraÇão De Gram:}

Na coloração Gram, o esfregaço bacteriano fixado é tratado pelas seguintes soluções: cristal violeta, solução iodo-iodetada, álcool ou álcool-acetona (agente descorante) e safranina ou outro contra-corante adequado. As bactérias coradas pelo método de Gram pertencem a dois grupos: bactérias gram-positivas (apresentam na parede celular grande quantidade de peptidioglicano), que retêm o cristal violeta e apresentam coloração violeta escura; e bactérias gram-negativas (apresentam na parede celular grande quantidade de lipídeos), que perdem o cristal violeta e são coradas pela safranina, apresentando, pois, a coloração vermelha. O exame dos esfregaços corados pelo método de Gram revela a morfologia e o comportamento tintorial das bactérias. Existem bactérias gram-variáveis, que são normalmente culturas velhas de bactérias gram-positivas que perdem a característica de reter o complexo cristal violeta iodo.

Este método utilizado na pesquisa foi modificado a partir do método de Hucker (Jenkins et al., 1993), segundo Villas Bôas (1999). 
A) Reagentes:

- Solução de violeta cristal:

- Solução A: dissolver 2,0 g de violeta cristal em 20 ml de álcool etílico;

- Solução B: dissolver 0,8 g de oxalato de amônio em 100 ml de água destilada.

Preparar as soluções separadamente e em seguida combiná-las.

- Solução de lugol:

Dissolver 1,0 de iodo e 2,0 de iodeto de potássio em $300 \mathrm{ml}$ de água destilada.

- Etanol 95\%

- Solução de safranina:

Misturar $10 \mathrm{ml}$ de safranina (2,5\% em etanol 95\%) com $100 \mathrm{ml}$ de água destilada.

B) Procedimento:

- Preparar o esfregaço (coletar uma gota da amostra com alça de platina e em seguida, espalhar a gota em lâmina para microscopia) e deixar secar ao ar;

- Cobrir a gota espalhada na lâmina com metanol e deixar evaporar à temperatura ambiente;

- Cobrir a amostra com solução de violeta cristal por 1 minuto;

- Lavar a lâmina com água corrente por 5 segundos;

- Cobrir a amostra com solução de lugol por 1 minuto; 
- Lavar a lâmina com água corrente por 5 segundos;

- Descolorir o esfregaço com etanol 95\% por 20 segundos. Em seguida, enxaguar com água destilada por 5 segundos;

- Realizar este procedimento até eliminar todo o excesso de violeta cristal;

- Cobrir a amostra com solução de safranina por 1 minuto;

- Lavar a lâmina com água corrente por 5 segundos;

- Secar a lâmina ao ar;

- Observar a lâmina ao microscópio óptico, em aumento de 1000 vezes, com óleo de imersão.

C) Interpretação dos resultados:

A coloração azul-violeta ou roxo intenso significa que o microrganismo é Gram-positivo. O Gram negativo é indicado por uma coloração vermelha/rosa. Bactérias gram-fracamente positivas coram em roxo claro, enquanto que nas gram-variáveis, partes do filamento coram em roxo (+) e o restante em vermelho-rosado. 


\section{- COLORAÇÃo DE NeISSER:}

Esta técnica é baseada em Eikelboom \& Buijsen (1981) apud Jenkins et al. (1993), segundo Villas Bôas (1999).

A) Reagentes:

- Solução 1:

- Solubilizar 0,1 g d azul de metileno em $5 \mathrm{ml}$ de álcool etílico 95\% e $5 \mathrm{ml}$ de ácido acético glacial e completar para $100 \mathrm{ml}$ com água destilada.

- Colocar 3,3 ml de violeta cristal $10 \%$ em 6,7 ml de álcool etílico 95\% e completar o volume para $100 \mathrm{ml}$ com água destilada;

- Solução 2:

- $\quad$ 33,3 ml de solução de Bismark Brown (1\% do peso/volume de água) acrescidas com $66,7 \mathrm{ml}$ de água destilada.

Preparar o corante misturando 2 partes $(20 \mathrm{ml})$ da solução 1 com uma parte $(10 \mathrm{ml})$ da solução 2, descritas acima.

B) Procedimento:

- Preparar o esfregaço e deixar secar ao ar;

- Cobrir a lâmina por 30 segundos com a solução 1, e em seguida, lavar com água rapidamente;

- Cobrir a lâmina por 1 minuto com a solução 2 e lavar bem com água. Em seguida, secar a lâmina com papel; 
- Observar a lâmina ao microscópio óptico, em aumento de 1000 vezes, com óleo de imersão.

C) Interpretação dos resultados:

O resultado positivo é azul-violeta, podendo-se apresentar na célula toda ou como grânulos intracelulares. Neisser negativo é amarelo-marrom.

\section{- TESDE DE OXIDAÇÃO DO ENXOFRE:}

Esta técnica foi modificada de Nielsen apud Jenkins et al. (1993), segundo Villas Bôas (1999).

A) Reagentes:

- Solução de tiossulfato de sódio $\left(\mathrm{Na}_{2} \mathrm{~S}_{2} \mathrm{O}_{3} \cdot 5 \mathrm{H}_{2} \mathrm{O}\right) 1 \mathrm{~g} / 100 \mathrm{ml}$.

B) Procedimento:

- Deixar sedimentar cada amostra de lodos ativados e transferir $20 \mathrm{ml}$ do sobrenadante para um erlenmeyer de $100 \mathrm{ml}$;

- Adicionar 1-2ml de amostra e $1 \mathrm{ml}$ de solução de tiossulfato de sódio no erlenmeyer (concentração final de tiossulfato deve ser e $2 \mathrm{mM}$ );

- Agitar o frasco toda noite, à temperatura ambiente;

- Fazer observação em microscopia de contraste de fase no aumento de 1000 vezes, com óleo de imersão. 
C) Interpretação dos resultados:

O teste de enxofre é positivo se ocorrer formação de grânulo intracelular azul-amarelado.

- COLORAÇÃo DE GRÂNUlo DE POLIBETAHIdROXIbUTIRATO (PHB):

Esta técnica é baseada em Jenkins et al. (1993), segundo Villas Bôas (1999).

A) Reagentes:

- Solução 1: Dissolver 3 g de Sudan Black B (IV) em 100 ml de uma solução de álcool etílico $60 \%$.

- Solução 2: Dissolver 5 g de safranina em 100 ml de uma solução de água destilada.

B) Procedimento:

- Preparar o esfregaço e deixar secar ao ar;

- Cobrir a lâmina com a solução 1 durante 10 minutos, tomando-se cuidado para não deixar secar. Se necessário, adicionar mais solução 1;

- Lavar a lâmina com água rapidamente;

- Cobrir a lâmina com a solução 2 por 10 segundos;

- Enxaguar com água destilada;

- Realizar o exame ao microscópio óptico, em aumento de 1000 vezes, com óleo de imersão. 
C) Interpretação dos resultados:

Grânulos de PHB apresentam-se intracelularmente com coloração azul-preta. O citoplasma pode apresentar-se rosa claro. 


\section{RESULTADOS E DISCUSSÃO}

Os experimentos realizados na presente dissertação de mestrado visaram, fundamentalmente, contribuir para a compreensão da influência do ácido fólico na atividade microbiana de lodos oriundos de um sistema de tratamento aeróbio - lodos ativados, empregado na estabilização de esgotos sanitários.

Inicialmente, através dos bioensaios de respirometria (baseados na Demanda Bioquímica de Oxigênio), buscou-se constatar se o ácido fólico, tanto o grau analítico como o presente no composto comercial Dosfolat, alteraria o comportamento respiratório da massa celular, ou seja, o consumo do oxigênio ao longo do tempo. Não foram considerados índices (cálculo da massa inicial de ácido fólico em relação a massa inicial celular) para discutir os resultados dos bioensaios. No âmbito dos experimentos optou-se em discutir a porcentagem do oxigênio consumido frente a concentração total do composto adicionado à massa celular inoculada, sem determinar o conteúdo de sólidos totais ou voláteis da mesma. Exames sob microscopia foram feitos para verificar os aspectos comuns nas diferentes amostras de lodo biológico de mesma origem inoculado nos ensaios.

Muito embora os bioensaios para determinação da DBO sejam amplamente utilizados no saneamento básico e ambiental para o monitoramento de sistemas de tratamento de resíduos, consituindo-se como um parâmetro fundamental e legal (CONAMA, 2005), não foi encontrada na literatura pertinente, a aplicação desses ensaios nos estudos primários sobre a influência do ácido fólico em lodos aeróbios. Assim, como será visto adiante, a discussão dos resultados obtidos será feita apenas entre os experimentos realizados, buscando indicar tendências do comportamento dos lodos estudados frente às adições de ácido fólico. 
Um segundo grupo de experimentos foi conduzido em sistema de lodos ativados em batelada seqüencial (sistemas descontínuos), em escala laboratorial. Os sistemas de reação que receberam as duas formas de ácido fólico possibilitaram ampliar as medições necessárias para confirmar e avaliar o grau de influência desse composto no lodo. O monitoramento microscópico também permitiu avaliar os tipos de floco e composição da microbiota estabelecidos nas condições de ensaio. A discussão dos resultados obtidos foi feita considerando a disponibilidade de informações na literatura, sobretudo em relação à adição do composto comercial Dosfolat. Foram realizadas considerações sobre os aspectos da microbiota e sua ecologia nos sistemas de reação, bem como foram brevemente comentados pontos sobre a bioquímica dos lodos submetidos à adição do ácido fólico. 


\subsection{Bioensaios de respirometria na presença de ácido fólico}

A seguir são apresentados os resultados obtidos na etapa experimental inicial da presente pesquisa, que consistiu nos cinco bioensaios de respirometria (sistemas controle). Aqui estão apresentados os resultados médios obtidos nestes, e os resultados das duplicatas de todas as concentrações de ácido fólico testadas, juntamente os valores de DBO obtidos, estão apresentados em tabelas do Anexo 2 deste trabalho.

\subsubsection{BIOENSAIO 1}

Os resultados do bioensaio número 1 estão apresentados na Tabela 11 e Figura 21. Os valores percentuais médios de consumo do oxigênio nos frascos ao final do ensaio com cinco volumes diferentes de lodo, sem e com a adição de duas concentrações de ácido fólico grau analítico (substância pura) - 1,0 e 2,0 mg/L, não revelaram diferenças em relação aos frascos controle. Entre as cinco concentrações de inóculo verifica-se que a atividade respiratória foi maior em função do volume crescente de lodo inicial, no período de 5 dias de incubação preconizado pelo ensaio respirométrico. Os resultados não conferem nada incomum ao comportamento dos lodos.

Nesse ensaio também constatou-se que cuidados com a dissolução adequada do ácido fólico eram essenciais, a fim de evitar que o ácido precipitasse e, portanto, não estivesse disponível às células microbianas. 
Tabela 11. Consumo total de oxigênio (\%) nos frascos do Bioensaio 1

\begin{tabular}{lccccc}
\hline \multirow{2}{*}{ FRASCOS } & \multicolumn{5}{c}{ VOLUME DE LODO $(\mathrm{mL})$} \\
\cline { 2 - 6 } & 0,1 & 0,5 & 1 & 1,5 & 2 \\
\hline Controle & 29 & 53 & 50,5 & 97,5 & 98,5 \\
Com 1,0 mg/L Ácido fólico & 30,5 & 51 & 66 & 98,5 & 99 \\
Com 2,0 mg/L Ácido fólico & 30,5 & 52,5 & 66 & 99 & 99,5 \\
\hline
\end{tabular}

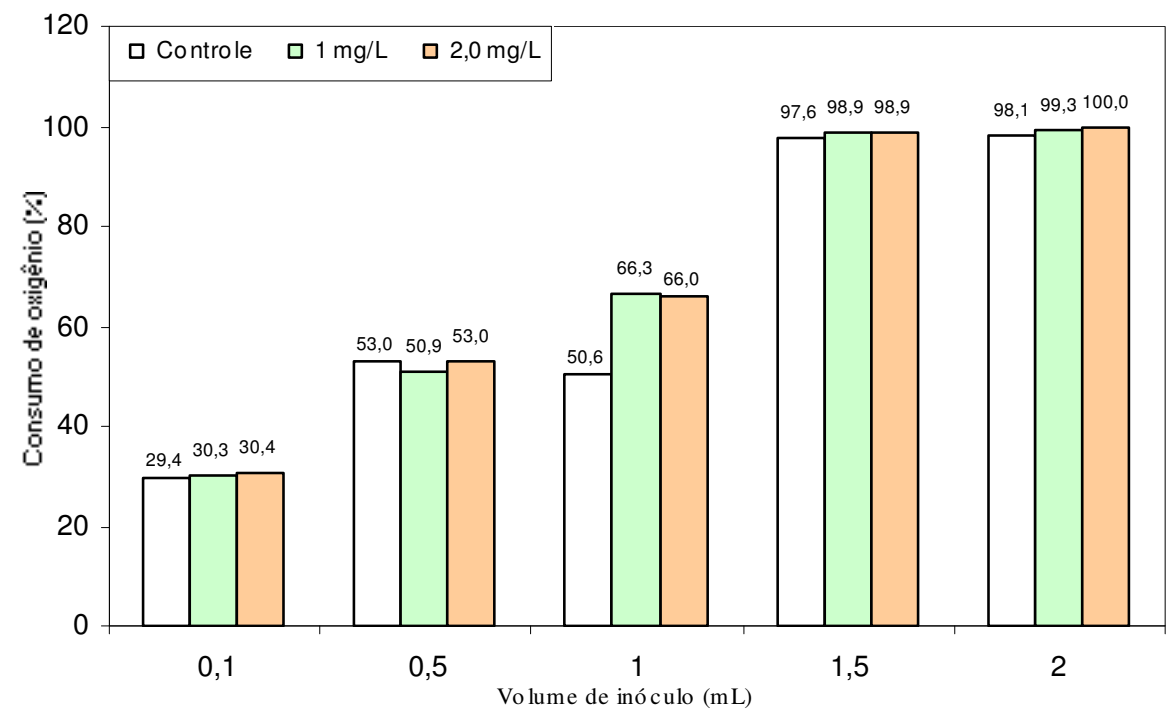

Figura 21. Consumo do oxigênio (\%) durante o Bioensaio 1 nos frascos com adição de 1,0 e 2,0 mg/L de ácido fólico grau analítico e em frascos controle. Ensaios realizados em duplicata.

\subsubsection{BIOENSAIO 2}

Os resultados do bioensaio número 2 estão apresentados na Tabela 12 e Figura 22. Referem-se aos valores percentuais médios de consumo do oxigênio nos frascos ao final do bionsaio, após cinco dias de incubação, com cinco volumes diferentes de lodo, sem e com a adição de duas concentrações de ácido fólico grau analítico - 2,5 e 4,0 mg/L. 
Analisando-se os resultados, constatou-se uma tendência maior no consumo de oxigênio nos sistemas de reação com ácido fólico, ou seja, os valores em porcentagem do consumo do oxigênio pelos lodos foram, em geral, superiores quando na presença do ácido fólico em ambas concentrações estudadas, em comparação aos reatores controle. O consumo de oxigênio foi mais acentuado sob adição de 4,0 mg/L de ácido fólico. Assim, pelos resultados pode-se observar que a relação da concentração de ácido fólico $(4,0 \mathrm{mg} / \mathrm{L})$ e massa de lodo (não determinada) foi a mais apropriada ao consumo de oxigênio disponível nas condições de ensaio.

Neste bioensaio, o preparo da solução de ácido fólico grau analítico com água fervente para dissolução desta vitamina evidencia uma possível melhora na absorção do composto pelas células, notadamente em relação ao Bioensaio 1, considerando-se que o inóculo foi de mesma origem. Cabe aqui ressaltar, como já descrito na metodologia deste trabalho, que nos outros bioensaios de respirometria efetuados (Bioensaios $n^{\circ} 3,4$ e 5) as soluções de ácido fólico foram preparadas com adição de bicarbonato de sódio para sua dissolução.

Tabela 12. Consumo total de oxigênio (\%) nos frascos do Bioensaio 2

\begin{tabular}{lccccc}
\hline \multirow{2}{*}{ FRAScOS } & \multicolumn{5}{c}{ VOLUME DE LODO $(\mathrm{mL})$} \\
\cline { 2 - 6 } & 0,1 & 0,3 & 0,5 & 1,0 & 1,5 \\
\hline Controle & 13 & 31 & 26 & 60 & 96 \\
Com 2,5 mg/L Ácido fólico & 17 & 36 & 47 & 72 & 100 \\
Com 4,0 mg/L Ácido fólico & 19 & 35 & 49 & 78 & 100 \\
\hline
\end{tabular}




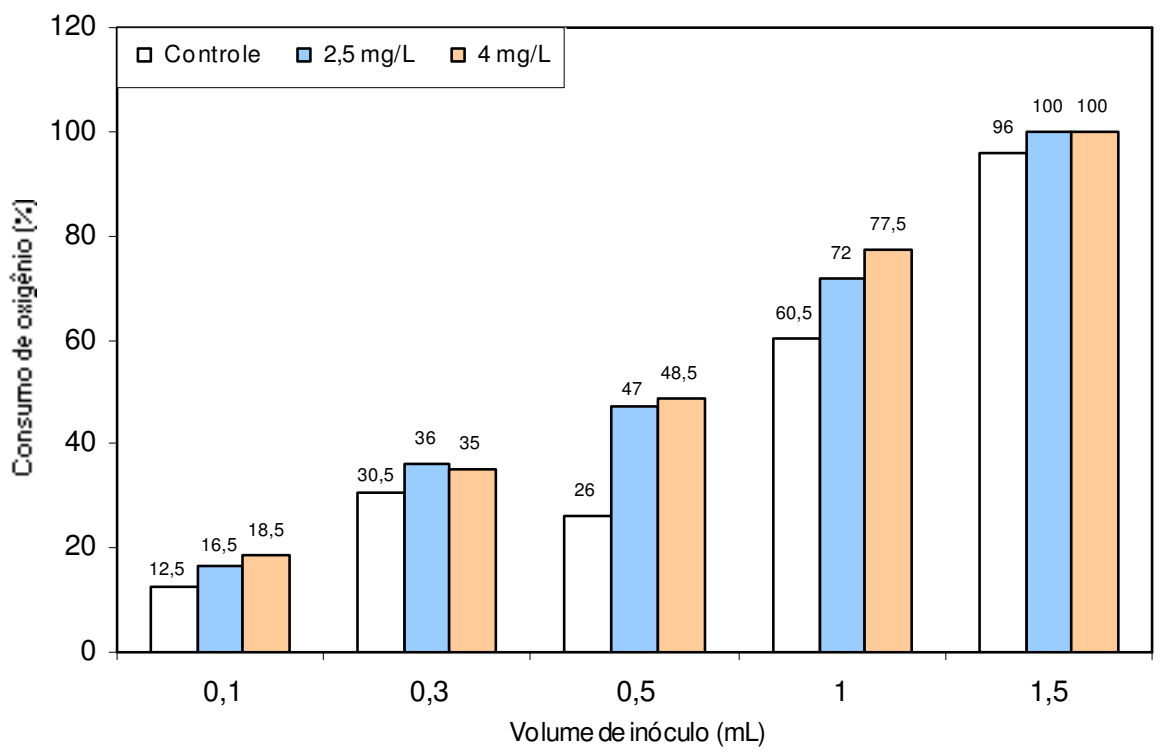

Figura 22. Consumo do oxigênio (\%) durante o Bioensaio 2 nos frascos com adição de 2,5 e 4,0 mg/L de ácido fólico grau analítico e em frascos controle. Ensaios realizados em duplicata.

\subsubsection{BIOENSAIO 3}

Os resultados do bioensaio número 3 estão apresentados na Tabela 13 e na Figura 23, e são relativos aos percentuais do consumo diário de oxigênio durante cinco dias de incubação, nos frascos contendo um volume de lodo de $0,5 \mathrm{~mL}$ como inóculo. As concentrações de ácido fólico estudadas foram de 2,5 e 4,0 mg/L.

Tabela 13. Consumo de oxigênio (\%) diário nos frascos do Bioensaio 3

\begin{tabular}{lccccc}
\hline \multirow{2}{*}{ FRAScos } & \multicolumn{5}{c}{ DIA DO ENSAIO } \\
\cline { 2 - 6 } & 10 & $2^{\circ}$ & $3^{\circ}$ & $4^{\circ}$ & $5^{\circ}$ \\
\hline Controle & 10 & 20 & 27 & 37 & 39 \\
Com 2,5 m g/L ácido fólico & 10 & 24 & 30 & 41 & 46 \\
Com 4,0 m g/L ácido fólico & 13 & 27 & 32 & 44 & 50 \\
\hline
\end{tabular}


Na Figura 23 estão plotados os valores de porcentagem do consumo de oxigênio obtidos no bioensaio 3 ao longo do período de incubação. As curvas mostram a tendência, já observada no bioensaio 2, no consumo superior de oxigênio na presença do ácido fólico. Não há possibilidade de referir qual a melhor concentração do composto, na medida que os valores médios de consumo de oxigênio foram próximos ao longo dos 5 dias de incubação.

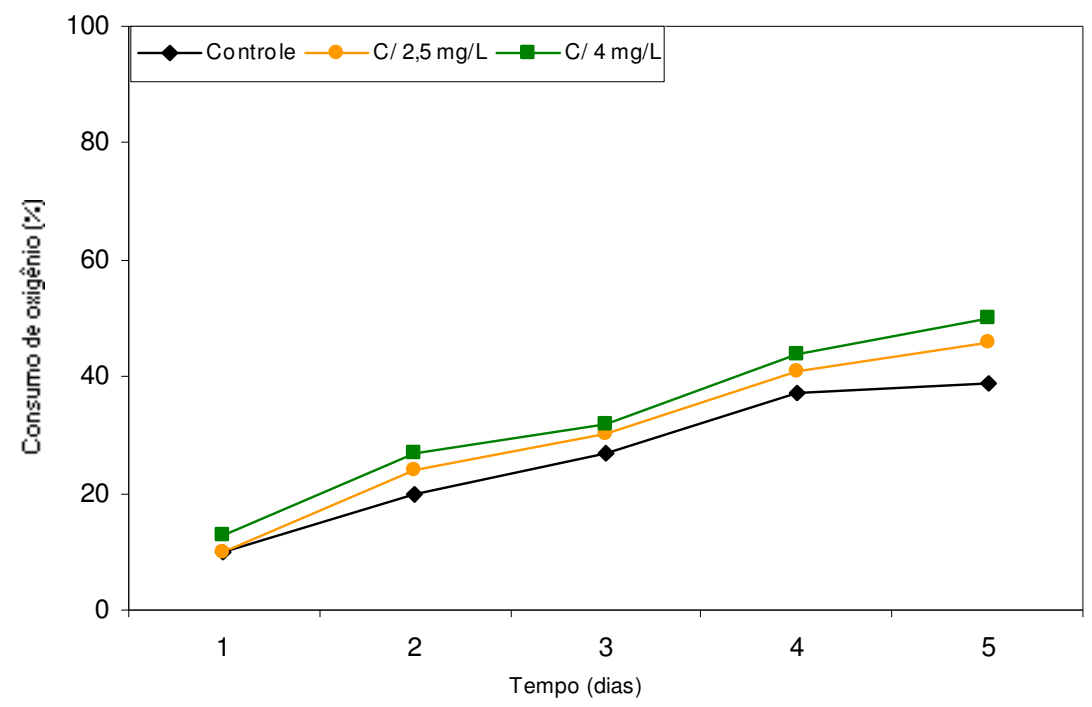

Figura 23. Consumo do oxigênio (\%) durante o Bioensaio 3 nos frascos com adição de 2,5 e 4,0 mg/L de ácido fólico grau analítico e em frascos controle. Ensaios realizados em duplicata.

\subsubsection{BIOENSAIO 4}

Os resultados do bioensaio número 4 estão apresentados na Tabela 14 e na Figura 24, com os valores percentuais médios de consumo de oxigênio durante cinco dias de incubação, nos frascos incubados, contendo $0,5 \mathrm{~mL}$ de lodo como inóculo, nas condições com adição de ácido fólico nas concentrações $0,5,2,5$ e $4 \mathrm{mg} / \mathrm{L}$, comparados aos frascos controle. 
Tabela 14. Consumo de oxigênio (\%) diário nos frascos do Bioensaio 4

\begin{tabular}{lccccc}
\hline \multirow{2}{*}{ FRASCOS } & \multicolumn{5}{c}{ DIA DO ENSAIO } \\
\cline { 2 - 6 } & $1^{\circ}$ & $2^{\circ}$ & $3^{\circ}$ & $4^{\circ}$ & $5^{\circ}$ \\
\hline Controle & 24 & 31 & 42 & 48 & 54 \\
Com 0,5 mg/L ácido fólico & 25 & 33 & 44 & 52 & 54 \\
Com 2,5 mg/L ácido fólico & 26 & 35 & 49 & 64 & 75 \\
Com 4,0 mg/L ácido fólico & 24 & 34 & 55 & 61 & 78 \\
\hline
\end{tabular}

Os valores dos percentuais de consumo do oxigênio ao longo dos experimentos foram superiores na presença de 2,5 e 4,0 mg/L de ácido fólico, no qual ao final do período de incubação ocorreu, respectivamente, o consumo de 75 e $78 \%$ do oxigênio presente nos frascos. Para os frascos controle deste bioensaio o consumo foi de $54 \%$ ao final da incubação. A adição de $0,5 \mathrm{mg} / \mathrm{L}$ de ácido fólico, contudo, manteve o consumo de oxigênio pelo lodo muito próximo aos dos frascos controle.

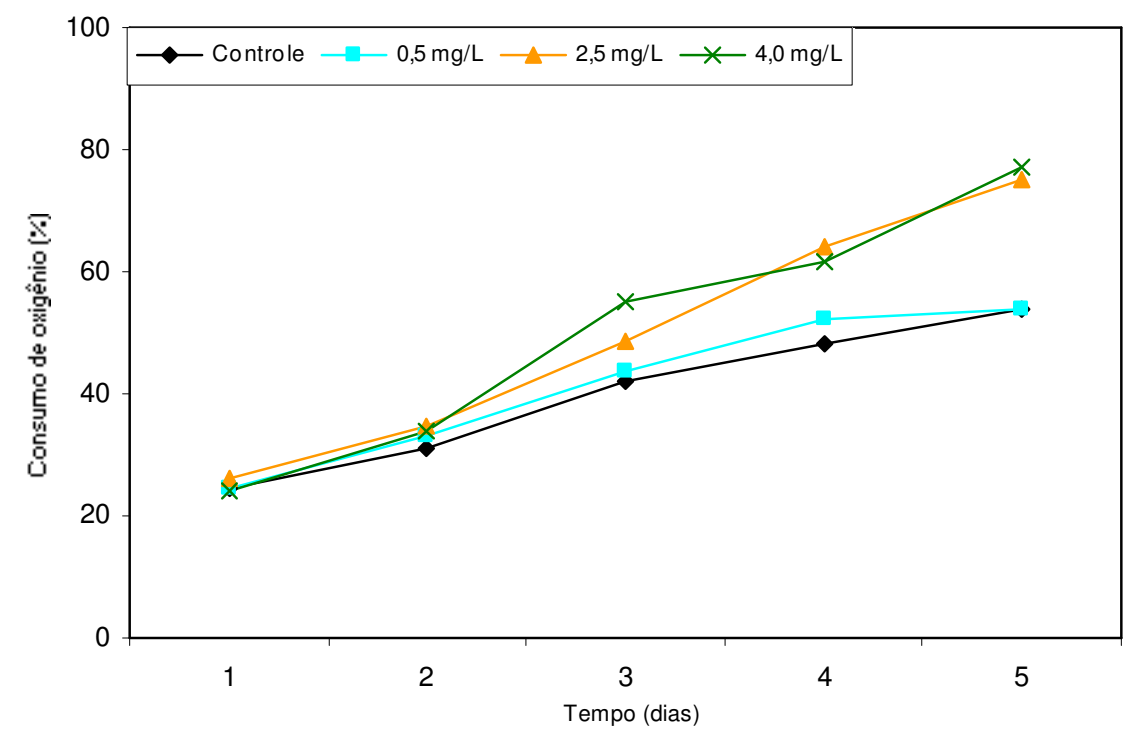

Figura 24. Consumo do oxigênio (\%) durante o Bioensaio 4 nos frascos com adição de 0,5; 2,5 e $4,0 \mathrm{mg} / \mathrm{L}$ de ácido fólico grau analítico e em frascos controle. Ensaios realizados em duplicata. 


\subsubsection{BIOENSAIO 5}

A avaliação dos resultados do bioensaio 5 mostrou que houve diferença acentuada no consumo do oxigênio pela adição do composto Dosfolat sobre a microbiota de lodos ativados, tanto em relação aos sistemas controle como aos que receberam apenas o do ácido fólico grau analítico. Porém, como desconhece-se a real concentração de ácido fólico no composto Dosfolat, deve-se ter o cuidado ao realizar essa comparação, sendo que foram empregadas as orientações para o preparo da solução apresentadas no manual comercial deste produto, para fins de comparação.

Foi evidenciado que o composto Dosfolat favoreceu a atividade dos lodos estudados, empregada segundo o recomendado pelo fabricante, $2,5 \mathrm{mg} / \mathrm{L}$ de Dosfolat (solução comercialmente preparada e distribuída). A Tabela 15 e a Figura 25 mostram que há influência positiva no incremento do consumo de oxigênio, sendo inoculados nos frascos o volume de $0,5 \mathrm{~mL}$ de lodo.

Ao final do bioensaio 5, o consumo diário médio de oxigênio pelos lodos na presença do ácido fólico grau analítico foi de $67 \%$, de $100 \%$ na presença do composto Dosfolat e 54\% nos frascos controle. Ainda, salienta-se que o Dosfolat influenciou o sistema após 24 h de incubação dos sistemas de respirometria. 
Tabela 15. Consumo de oxigênio (\%) diário dos frascos do Bioensaio 5

\begin{tabular}{lccccc}
\hline \multirow{2}{*}{ FRAScos } & \multicolumn{5}{c}{ DIA DO ENSAIO E CONSUMO OD (\%) } \\
\cline { 2 - 6 } & $1^{\circ}$ & $2^{\circ}$ & $3^{\circ}$ & $4^{\circ}$ & $5^{\circ}$ \\
\hline Controle & 7 & 20 & 41 & 56 & 54 \\
Com 2,5 mg/L de ácido fólico & 6 & 24 & 48 & 65 & 67 \\
Com 2,5 mg/L de Dosfolat & 62 & 99 & 99 & 99 & 100 \\
\hline
\end{tabular}

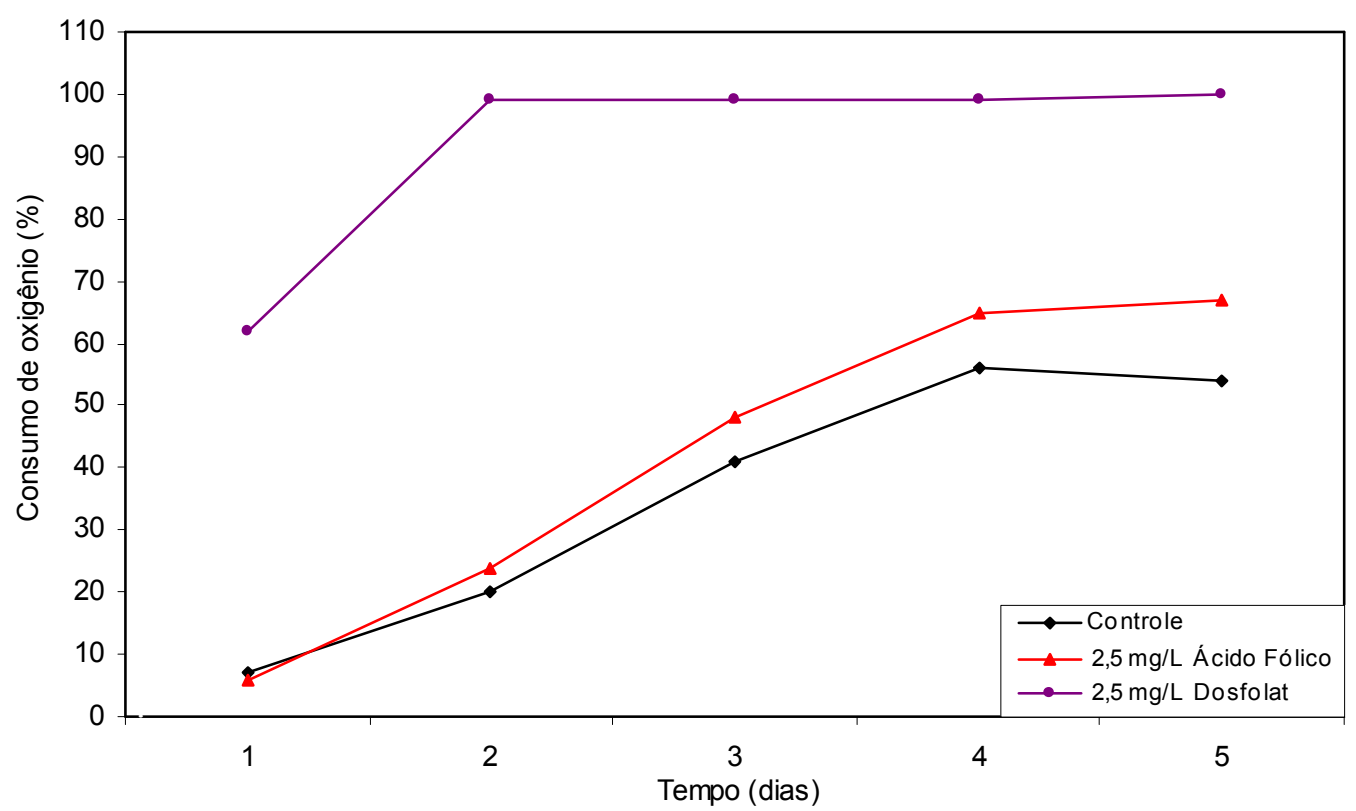

Figura 25. Consumo de oxigênio (\%) durante o Bioensaio 5 nos frascos com adição de $2,5 \mathrm{mg} / \mathrm{L}$ de ácido fólico e com adição do composto Dosfolat nas condições recomendadas pelo fabricante $(2,5 \mathrm{mg} / \mathrm{L})$ e em frascos controle.

Ensaios realizados em duplicata.

De maneira geral, pode-se admitir que os 5 bioensaios foram realizados com amostras de lodos ativados (inóculos) adequadas, pela análise dos valores de consumo de oxigênio dos frascos controle sempre próximas a $50 \%$ ou mais. Esse ponto merece destaque, uma vez que os lodos, ainda que de mesma origem, foram obtidos em períodos diferentes do reator da Estação de Tratamento de esgotos sanitários ETE ABC. É importante considerar que devido a 
este fator, os inóculos utilizados nos bioensaios apresentavam diferentes concentrações de sólidos em suspensão voláteis, e portanto, diferentes densidades de microrganismos, que, sendo submetidos às mesmas concentrações de ácido fólico, manifestaram diferentes níveis de consumo de oxigênio.

Os resultados destes bioensaios de DBO, considerado apenas como um ensaio respirométrico nesta pesquisa, revelaram maiores taxas de consumo do oxigênio na presença do ácido fólico grau analítico e do composto Dosfolat.

Akerboom et al. (1994), em pesquisa com aplicação de ácido fólico em estação de tratamento de efluente de indústria de papel reciclado, também realizou testes de respirometria, obtendo como resultados taxas de respiração maiores com ácido fólico. Outro autor, Ostrander (1992), que estudou a aplicação e influência do composto Dosfolat em estação municipal de tratamento de esgotos domésticos, também realizou bioensaios de respirometria, e também observou taxas de consumo de oxigênio mais altas no lodo, sendo 50\% maiores após a adição de Dosfolat. A partir destes resultados, os autores sugeriram que ocorreu aumento da velocidade do metabolismo dos microrganismos do lodo com a aplicação deste composto, e com solução de ácido fólico puro. É importante ressaltar que o Dosfolat contem outros componentes além de ácido fólico.

A otimização que o ácido fólico exerce na atividade enzimática das bactérias pode ser explicada pelo aumento da capacidade de consumo através de diferentes processos metabólicos, pelo aumento da atividade de algumas cadeias metabólicas. Um fator importante que ocorreu nos bioensaios foi a reação que ocorre com a adição de bicarbonato de sódio $\left(\mathrm{NaHCO}_{3}\right)$ na solução de ácido fólico para o seu preparo, que o reduz enzimaticamente, tornando-o na forma biologicamente ativa do ácido fólico, o tetraidrofolato. Desta forma o ácido fólico torna-se disponível às células para reações importantes ao metabolismo, como por exemplo, as de transferência dos grupos metila, formila, etc. 


\subsubsection{OBSERVAÇÕES DO EXAME MICROSCÓPICO DO LODO UTILIZADO COMO INÓCULO NOS BIOENSAIOS DE RESPIROMETRIA}

As amostras de lodos ativados utilizadas como inóculo nos bioensaios de respirometria, proveniente da linha de retorno da Estação de Tratamento de Esgotos do ABC (ETE ABC), foram examinadas por observação ao microscópio óptico sob iluminação de campo claro e contraste de fase, sendo observado que os flocos do lodo apresentavam boas características, tanto em relação à sua morfologia, quanto à abundância relativa de organismos filamentosos e os efeitos destes na estrutura dos flocos. A maioria dos flocos apresentava forma irregular, com estrutura compacta e tamanho médio, entre 150 a $500 \mu \mathrm{m}$. Quanto aos organismos filamentosos, estes foram observados em todos os flocos em densidade baixa - cerca de 1 a 5 filamentos por floco, desempenhando o efeito de construção na estrutura dos flocos.

Os organismos estavam ativos no momento da análise, apresentando motilidade, e uma diversidade equilibrada de organismos, sem a predominância de grupo ou gênero sobre os demais componentes da comunidade. Verificou-se a presença de células livres em suspensão, e entre os protozoários, observou-se a presença de ciliados livre-natantes, ciliados pedunculados, ciliados livres predadores de flocos, flagelados e rizópodes. Outro grupo integrante da microbiota destas amostras de lodo é o dos micrometazoários, representados pela presença de rotíferos e anelídeos, sendo também foi verificada a presença de alguns tardígrados.

O aspecto do lodo, como a morfologia dos flocos, abundância relativa de bactérias filamentosas e os organismos representativos, foram registrados fotograficamente, e as fotomicrografias estão apresentadas nas Figuras 26 a 31. 


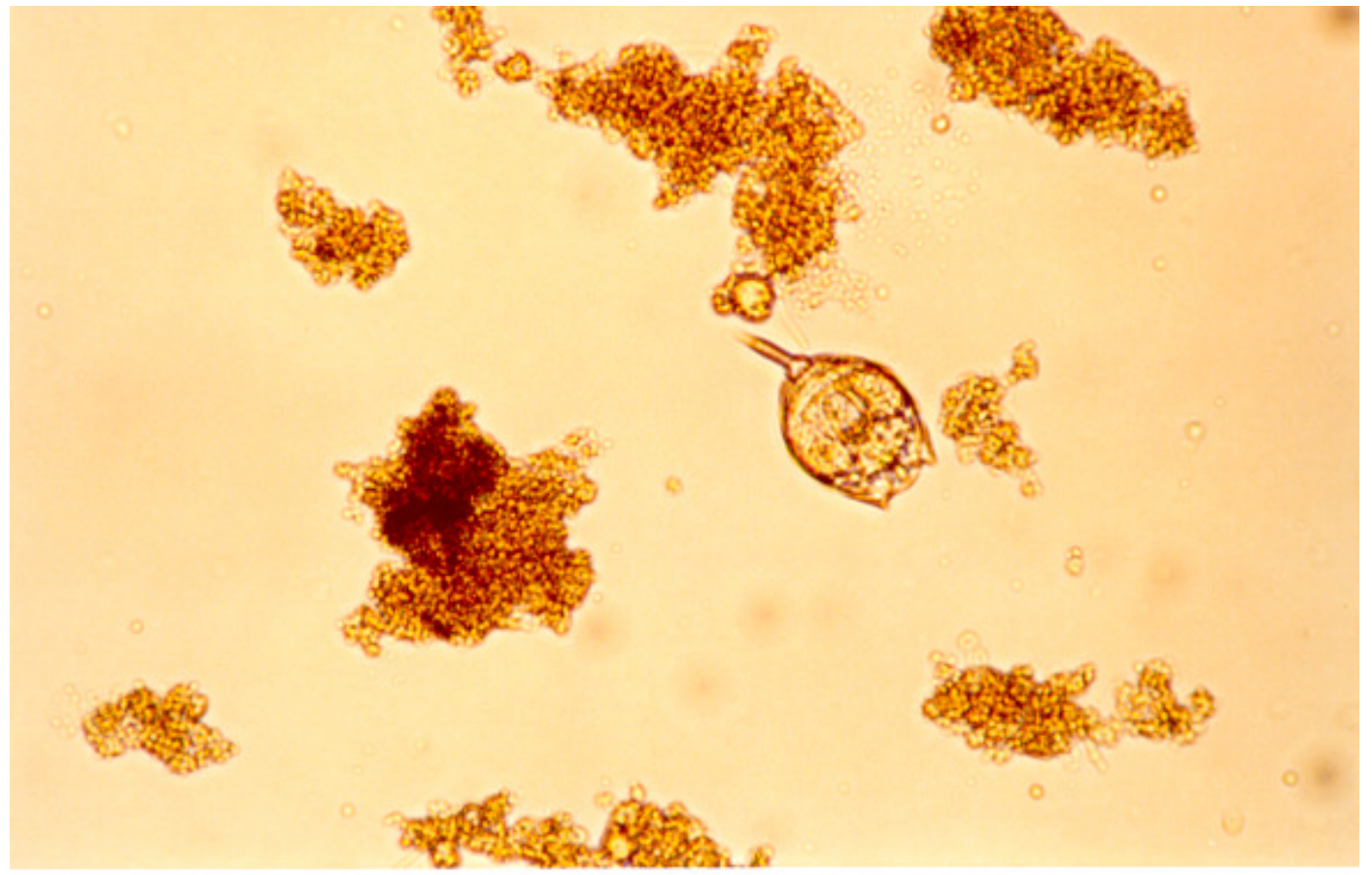

Figura 26. Vista do lodo biológico da ETE ABC, apresentando boas características, onde se observa um rotífero próximo ao centro do campo (100X)

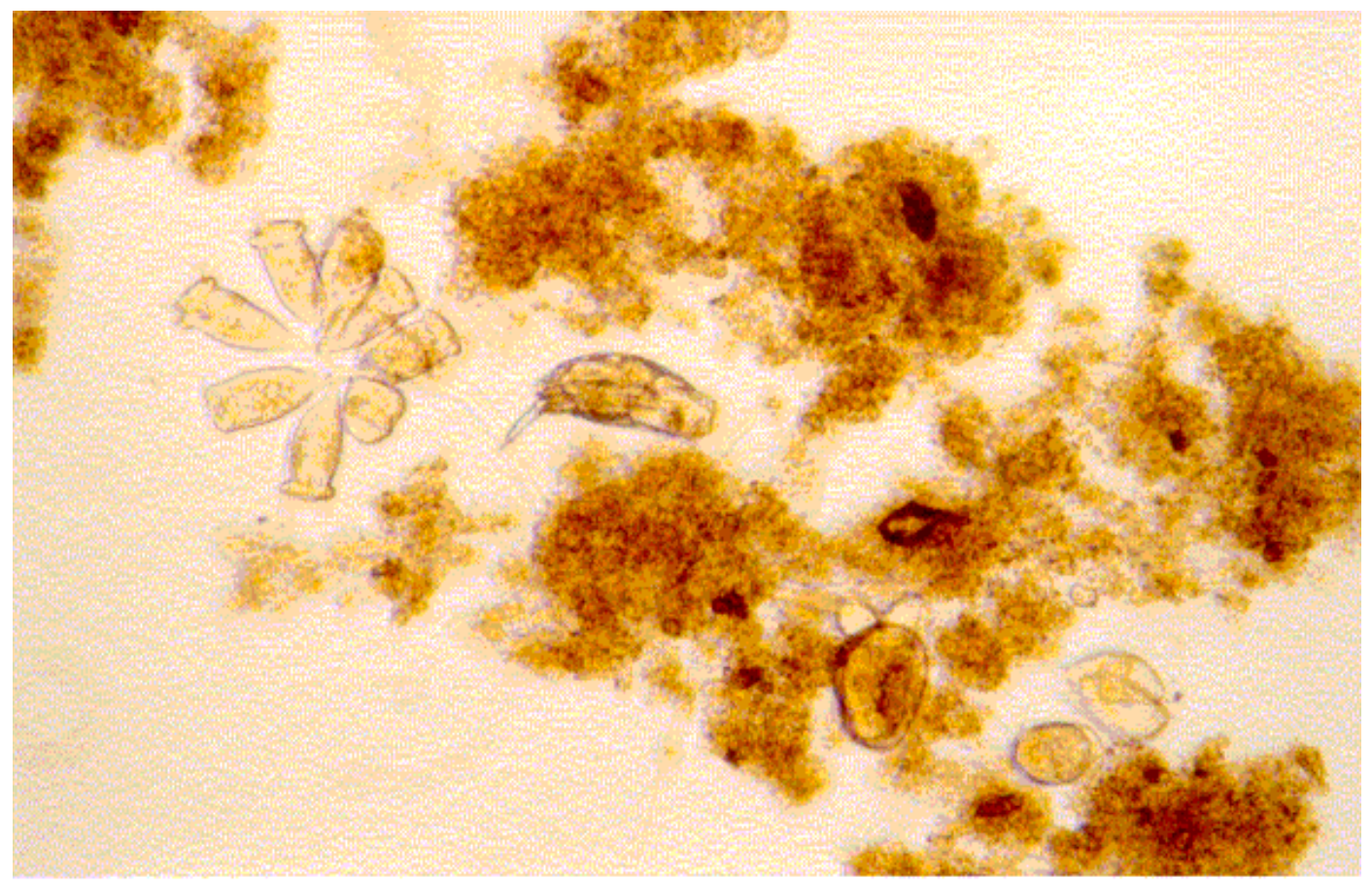

Figura 27. Aspecto da comunidade do lodo, mostrando a presença de rotífero, ao centro; protozoário ciliado pedunculado, Epistylis spp, no campo superior à esquerda; e alguns ciliados, à direita do campo inferior (contraste de fase, 100X) 


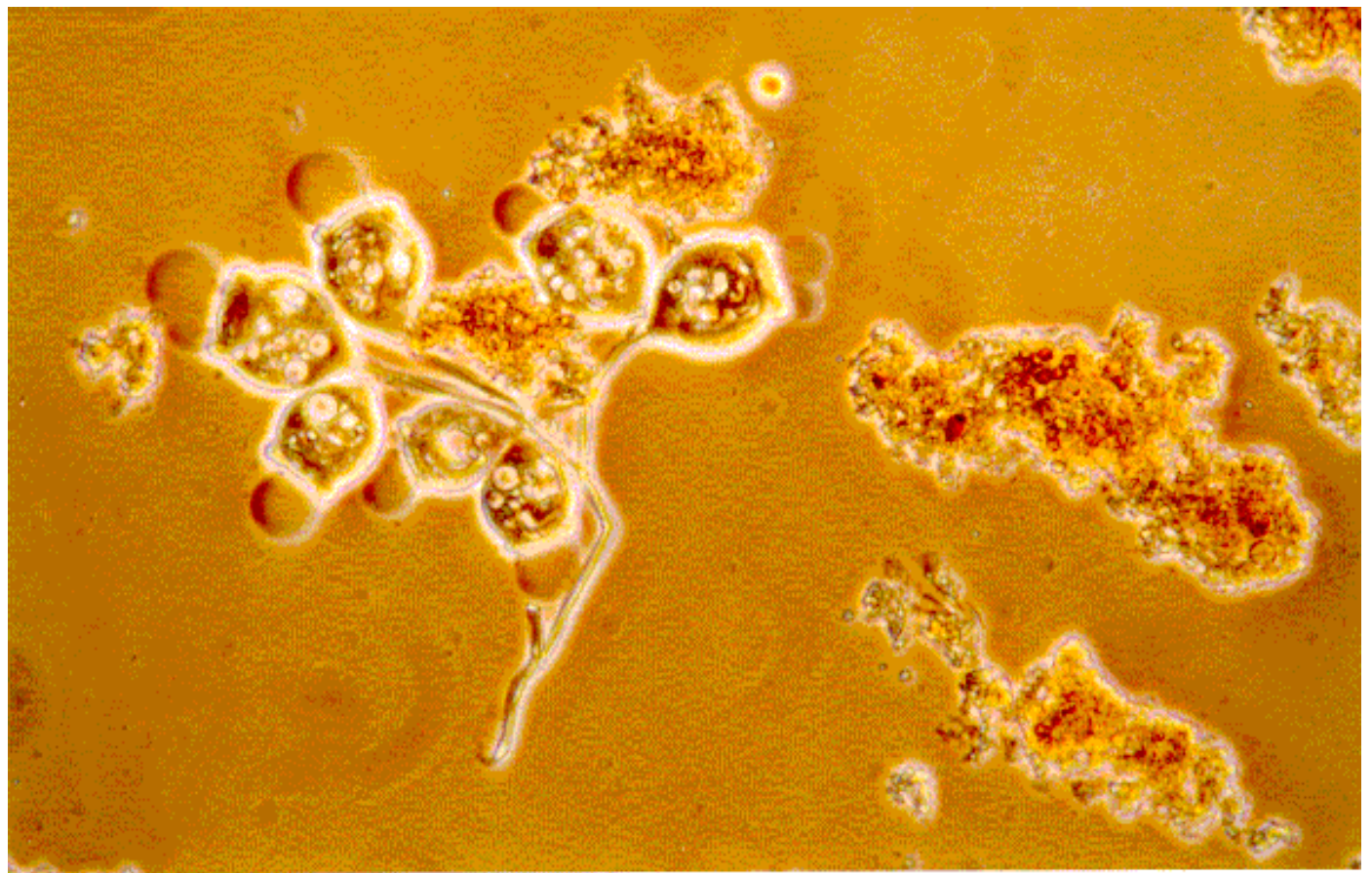

Figura 28 - Protozoário ciliado pedunculado, Opercularia spp, entre os flocos do lodo (contraste de fase, 100X)

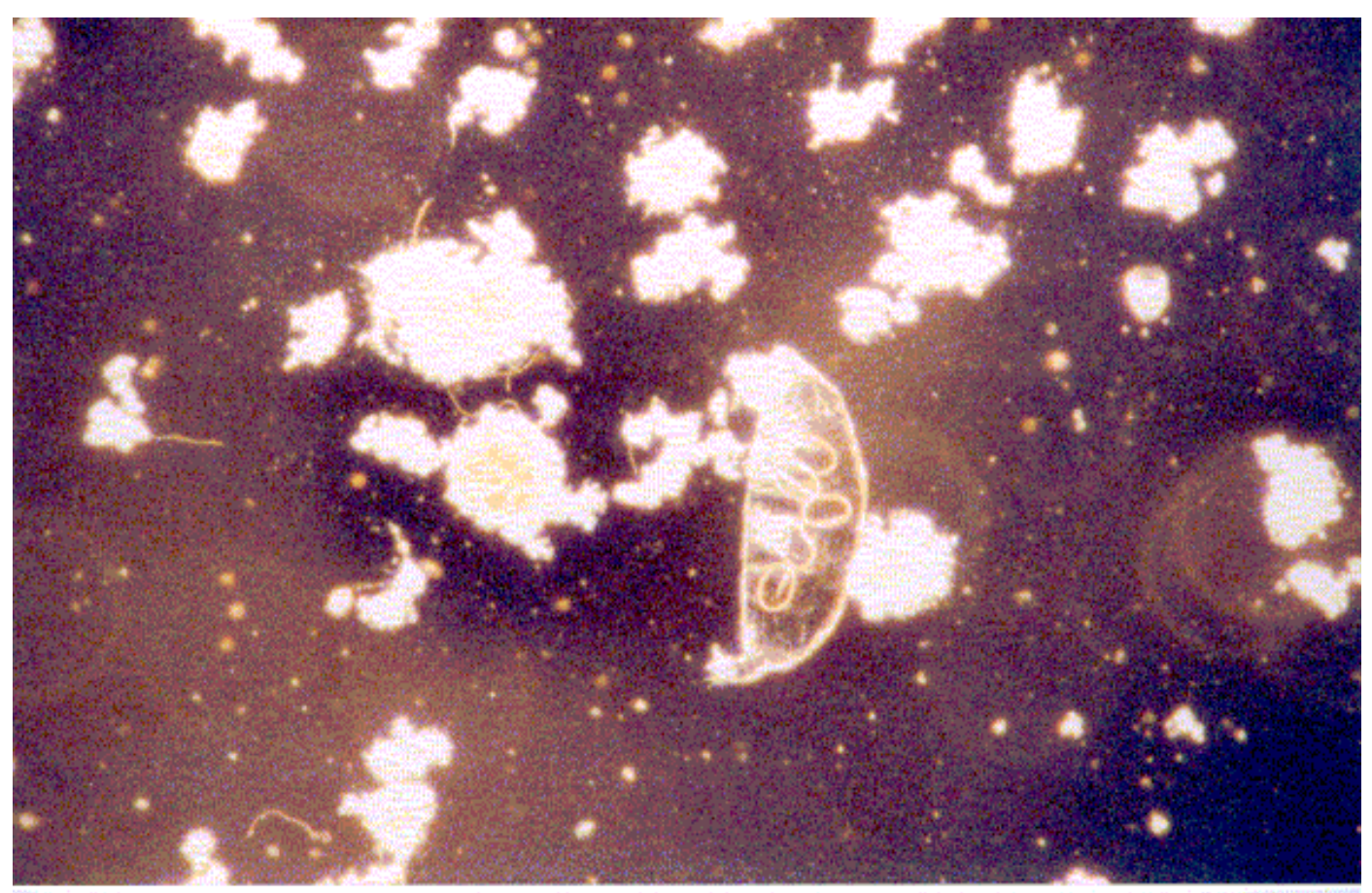

Figura 29 - Flocos do lodo, onde se observa no centro do campo um tardígrado com ovos, entre flocos (contraste de fase, 40X) 


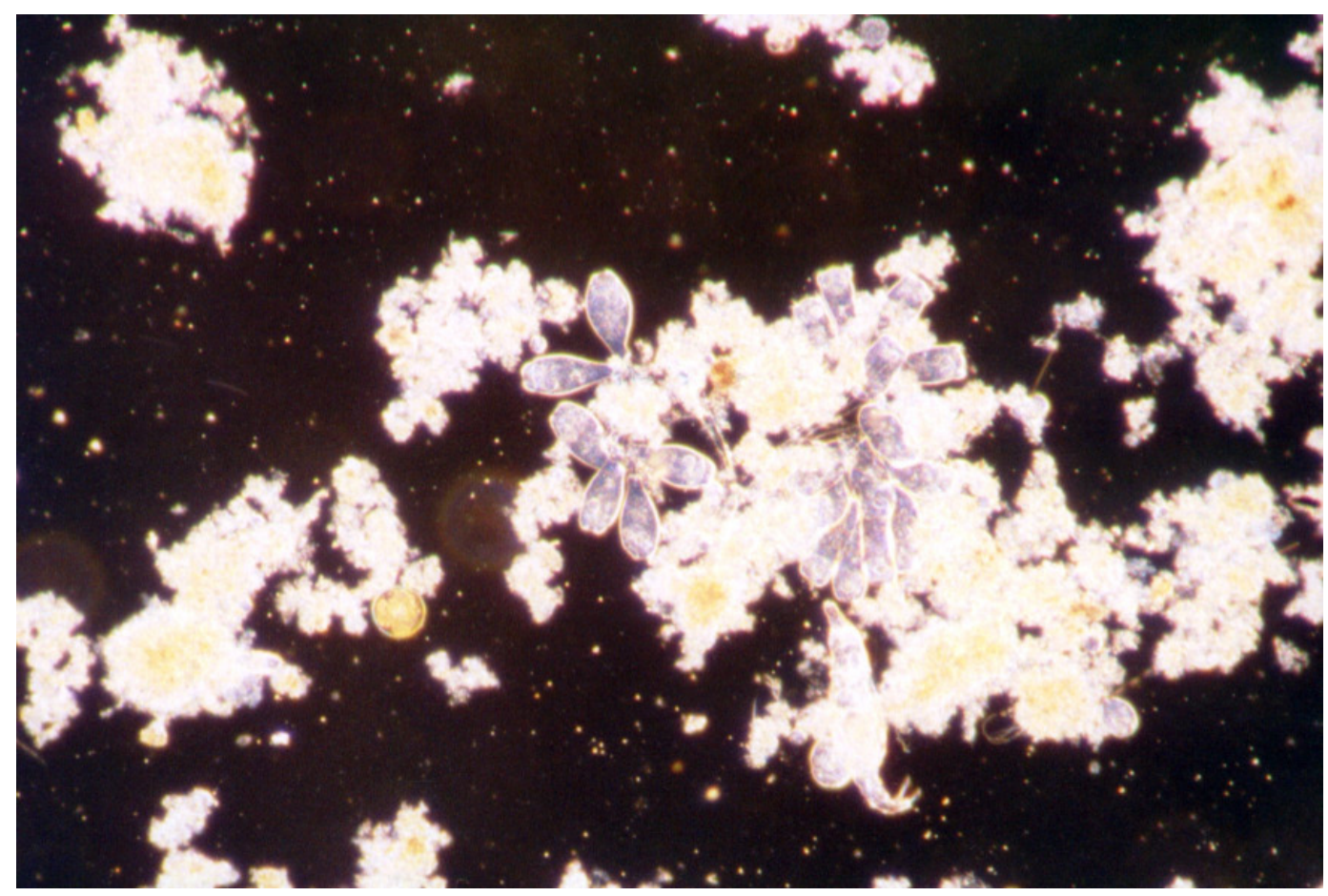

Figura 30 - Fauna típica da amostra de lodos ativados da ETE ABC, mostrando Vorticella sp entre flocos (em contraste de fase, 40X)

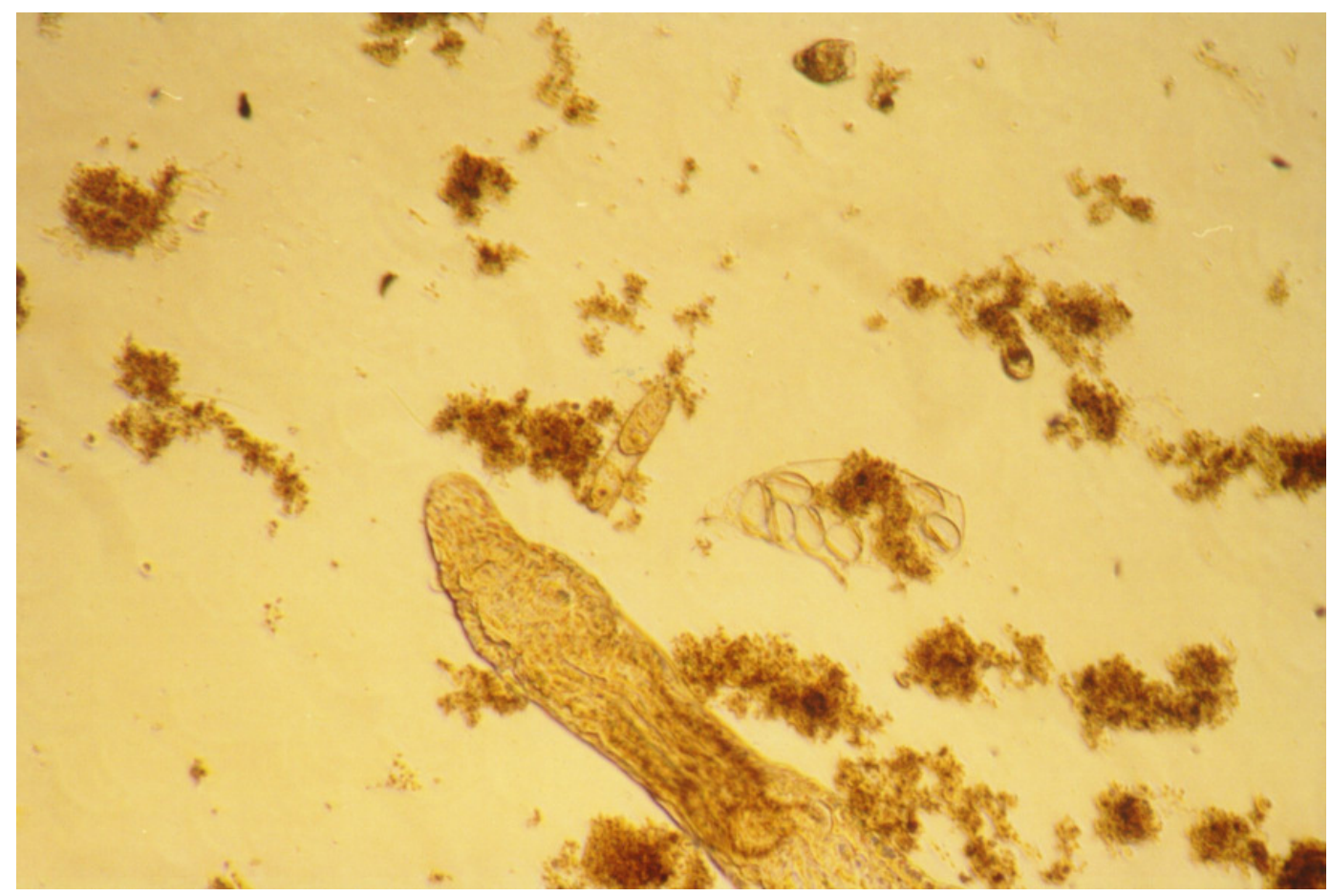

Figura 31 - Fotomicrografia mostrando organismos presentes no lodo biológico da ETE ABC, em que se vê anelídeo, tardigrado com ovos, Vaginicola sp e outros ciliados entre os flocos (40X) 


\subsection{Experimento de lodos ativados em batelada seqüencial (sistemas descontínuos)}

\subsubsection{Resultados relativos aos parâmetros físico-químicos}

\subsubsection{Sólidos em suspensão totais no tanque de aeração}

Os resultados de sólidos em suspensão totais no tanque de aeração (SSTTA), obtidos dos sistemas com adição de ácido fólico, com Dosfolat e controle durante o período de operação, estão apresentados na Tabela 16 e na Figura 32.

Tabela 16 - Concentração de sólidos em suspensão totais no lodo dos reatores com adição de ácido fólico e com adição de Dosfolat, comparados ao reator controle

\begin{tabular}{|c|c|c|c|c|}
\hline \multirow{2}{*}{ № } & \multirow{2}{*}{ DATA } & \multicolumn{3}{|c|}{ SSTA (mg/L) } \\
\hline & & TQ controle & TQ. AF & TQ. Dosfolat \\
\hline 1 & 06/09 & 1652 & 1618 & 1640 \\
\hline 2 & 08/09 & 1434 & 1408 & 1360 \\
\hline 3 & $12 / 09$ & 1224 & 1258 & 1314 \\
\hline 4 & $14 / 09$ & 1368 & 1382 & 1372 \\
\hline 5 & $19 / 09$ & 1570 & 1468 & 1586 \\
\hline 6 & $21 / 09$ & 1300 & 1212 & 1406 \\
\hline 7 & $23 / 09$ & 1504 & 1452 & 1536 \\
\hline 8 & $26 / 09$ & 1434 & 1474 & 1506 \\
\hline 9 & $28 / 09$ & 1502 & 1504 & 1472 \\
\hline 10 & $30 / 09$ & 1474 & 1434 & 1440 \\
\hline 11 & $03 / 10$ & 1550 & 1478 & 1528 \\
\hline 12 & $05 / 10$ & 900 & 1087 & 1311 \\
\hline 13 & $18 / 10$ & 1526 & 1426 & 1428 \\
\hline 14 & $19 / 10$ & 1808 & 1794 & 1628 \\
\hline 15 & $20 / 10$ & 1676 & 1596 & 1582 \\
\hline 16 & $24 / 10$ & 1920 & 1846 & 1806 \\
\hline 17 & $25 / 10$ & 1754 & 1844 & 1780 \\
\hline
\end{tabular}


continua

\begin{tabular}{ccccc}
\hline \multirow{2}{*}{ № } & DATA & \multicolumn{3}{c}{ SSTA (mg/L) } \\
\cline { 3 - 5 } & & TQ controle & TQ. AF & TQ. Dosfolat \\
\hline 18 & $27 / 10$ & 2000 & 2002 & 1926 \\
19 & $31 / 10$ & 1848 & 1846 & 1830 \\
20 & $01 / 11$ & 1856 & 1892 & 1886 \\
21 & $02 / 11$ & 1876 & 1892 & 1700 \\
22 & $03 / 11$ & 1714 & 1892 & 1738 \\
23 & $04 / 11$ & 1864 & 1854 & 1796 \\
24 & $05 / 11$ & 1952 & 1888 & 1884 \\
\hline MÉDIA & & 1873 & 1895 & 1823 \\
MÁXIMO & & 2000 & 2002 & 1926 \\
MÍNIMO & & 1714 & 1846 & 1700 \\
DESVIO PADRÃO & 83 & 47 & 77 \\
\hline
\end{tabular}

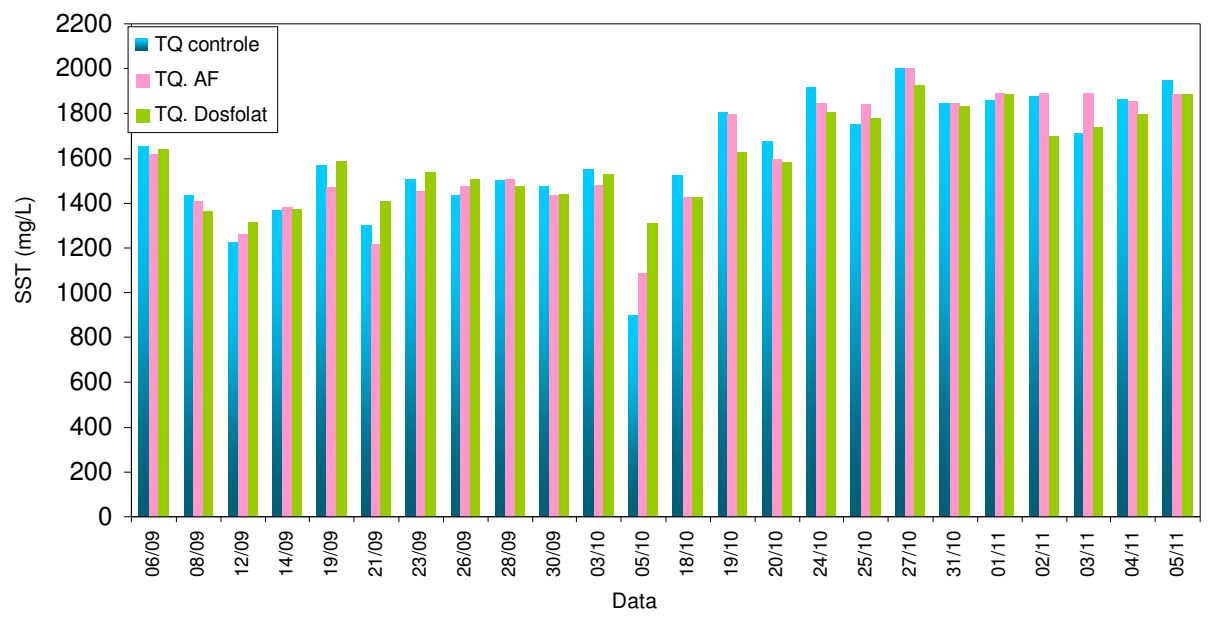

Figura 32 - Variação da concentração de sólidos em suspensão totais nos reatores em função do tempo

Os resultados de sólidos em suspensão totais no lodo dos reatores com adição de ácido fólico, com o composto Dosfolat e controle são muito próximos, como observado nos valores médios de todo o período operacional, situando-se em torno de $1600 \mathrm{mg} / \mathrm{L}$ no lodo destes três reatores. Desta forma, é possível afirmar que nas condições experimentais adotadas o ácido fólico e o Dosfolat não exerceram influência na produção de sólidos, não ocorrendo redução 
da geração de lodo com a aplicação de ambas as soluções, evidenciado pelos resultados de sólidos em suspensão voláteis, como apresentado na Tabela 17 e Figura 33, que obviamente também mostraram resultados dos três reatores muito próximos durante todo o período

\subsection{Sólidos em suspensão voláteis no tanque de aeração (SSVTA)}

Os resultados relativos à concentração de sólidos em suspensão voláteis no reator com adição de ácido fólico e com Dosfolat, comparados ao controle, estão mostrados na Tabela 17, que apresenta os valores dos ensaios e as médias obtidas durante o período de operação, e plotados na Figura 33.

Tabela 17 - Concentração de sólidos em suspensão voláteis no lodo dos reatores

\begin{tabular}{ccccc} 
& & & & continua \\
\hline \multirow{2}{*}{ № } & DATA & & SSVTA (mg/L) & \\
\cline { 3 - 5 } & & TQ. Controle & TQ. Ácido Fólico & TQ. Dosfolat \\
\hline 1 & $06 / 09$ & 1382 & 1388 & 1380 \\
2 & $08 / 09$ & 1206 & 1190 & 1118 \\
3 & $12 / 09$ & 1032 & 1060 & 1120 \\
4 & $14 / 09$ & 1162 & 1174 & 1172 \\
5 & $19 / 09$ & 1326 & 1234 & 1358 \\
6 & $21 / 09$ & 1106 & 1028 & 1206 \\
7 & $23 / 09$ & 1314 & 1246 & 1326 \\
8 & $26 / 09$ & 1236 & 1272 & 1298 \\
9 & $28 / 09$ & 1284 & 1280 & 1274 \\
10 & $30 / 09$ & 1278 & 1234 & 1264 \\
11 & $03 / 10$ & 1348 & 1276 & 1336 \\
12 & $05 / 10$ & 880 & 1012 & 1210 \\
13 & $18 / 10$ & 1340 & 1246 & 1274
\end{tabular}


Tabela 17 - Concentração de sólidos em suspensão voláteis no lodo dos reatores

\begin{tabular}{|c|c|c|c|c|}
\hline \multirow{2}{*}{ № } & \multirow{2}{*}{ DATA } & \multicolumn{3}{|c|}{ SSVTA (mg/L) } \\
\hline & & TQ. Controle & TQ. Ácido Fólico & TQ. Dosfolat \\
\hline 14 & $19 / 10$ & 1590 & 1572 & 1438 \\
\hline 15 & $20 / 10$ & 1492 & 1406 & 1382 \\
\hline 16 & $24 / 10$ & 1694 & 1624 & 1604 \\
\hline 17 & $25 / 10$ & 1552 & 1634 & 1576 \\
\hline 18 & $27 / 10$ & 1778 & 1784 & 1716 \\
\hline 19 & $31 / 10$ & 1654 & 1640 & 1618 \\
\hline 20 & $01 / 11$ & 1656 & 1694 & 1700 \\
\hline 21 & $02 / 11$ & 1632 & 1684 & 1502 \\
\hline 22 & $03 / 11$ & 1526 & 1688 & 1550 \\
\hline 23 & $04 / 11$ & 1652 & 1644 & 1598 \\
\hline 24 & $05 / 11$ & 1702 & 1678 & 1588 \\
\hline \multicolumn{2}{|c|}{ MÉDIA } & 1630 & 1641 & 1570 \\
\hline \multicolumn{2}{|c|}{ MÁXIMO } & 1778 & 1784 & 1716 \\
\hline \multicolumn{2}{|c|}{ MíNIMO } & 1492 & 1406 & 1382 \\
\hline \multicolumn{2}{|c|}{ DESVIO PADRÃC } & 80 & 90 & 96 \\
\hline
\end{tabular}

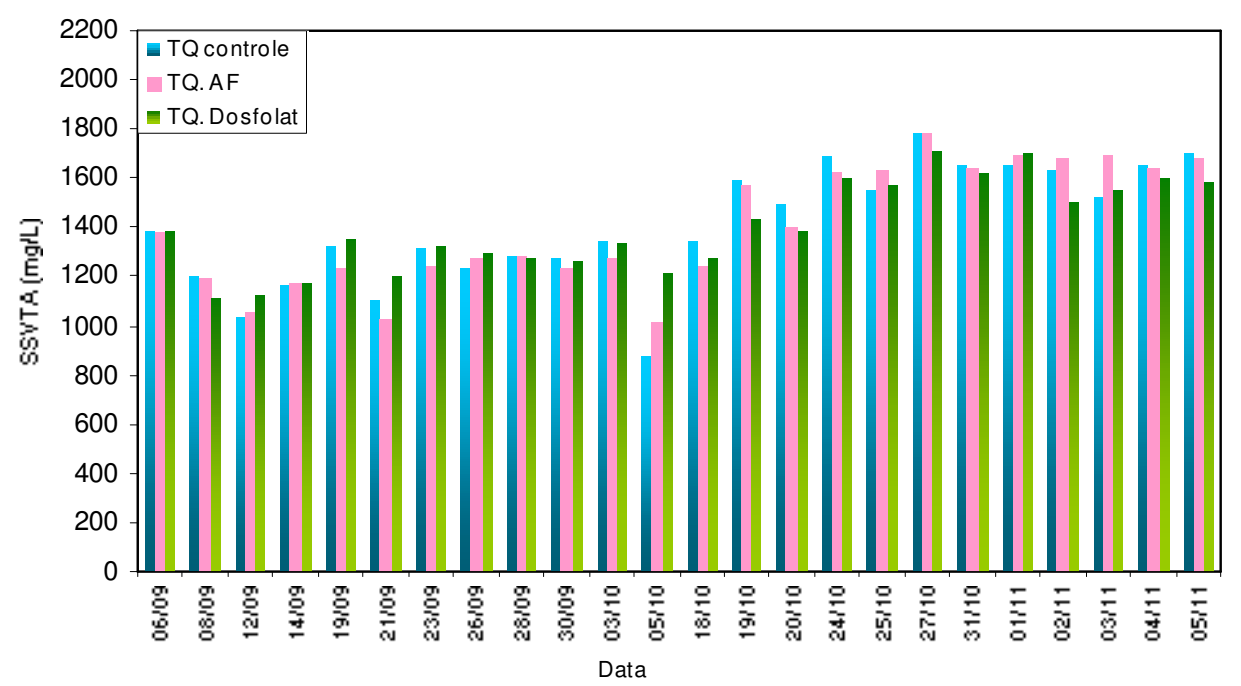

Figura 33 - Variação da concentração de sólidos em suspensão voláteis nos reatores em função do tempo 


\subsection{Sólidos em suspensão totais no efluente final}

Os resultados relativos à concentração de sólidos em suspensão totais (SST) no efluente final dos sistemas com adição de ácido fólico e com Dosfolat, comparados ao controle, estão mostrados na Tabela 18, e plotados na Figura 34.

Tabela 18 - Concentração de SST no efluente final dos reatores

\begin{tabular}{|c|c|c|c|c|}
\hline \multirow{2}{*}{ № } & \multirow{2}{*}{ DATA } & \multicolumn{3}{|c|}{ SST (mg/L) NO EFLUENTE FINAL } \\
\hline & & TQ controle & TQ. AF & TQ. Dosfolat \\
\hline 1 & 08/09 & 48 & 52 & 38 \\
\hline 2 & $12 / 09$ & 32 & 18 & 22 \\
\hline 3 & $21 / 09$ & 6 & 10 & 26 \\
\hline 4 & $23 / 09$ & 16 & 10 & 0 \\
\hline 5 & $26 / 09$ & 18 & 24 & 12 \\
\hline 6 & $28 / 09$ & 18 & 30 & 20 \\
\hline 7 & $30 / 09$ & 10 & 10 & 8 \\
\hline 8 & $03 / 10$ & 16 & 16 & 18 \\
\hline 9 & $05 / 10$ & 4 & 11 & 3 \\
\hline 10 & $18 / 10$ & 6 & 8 & 6 \\
\hline 11 & $19 / 10$ & 8 & 26 & 6 \\
\hline 12 & $20 / 10$ & 10 & 12 & 4 \\
\hline 13 & $24 / 10$ & 28 & 24 & 30 \\
\hline 14 & $25 / 10$ & 24 & 18 & 10 \\
\hline 15 & $27 / 10$ & 22 & 19 & 13 \\
\hline 16 & $31 / 10$ & 18 & 30 & 28 \\
\hline 17 & $01 / 11$ & 6 & 20 & 20 \\
\hline 18 & $02 / 11$ & 23 & 27 & 33 \\
\hline 19 & $03 / 11$ & 14 & 17 & 22 \\
\hline 20 & $04 / 11$ & 24 & 16 & 7 \\
\hline 21 & $05 / 11$ & 20 & 15 & 13 \\
\hline MÉ & & 18 & 20 & 16 \\
\hline MÁ & & 48 & 52 & 38 \\
\hline Mí & & 4 & 8 & 0 \\
\hline $\mathrm{DE}$ & DRÃO & 10,2 & 9,7 & 10,4 \\
\hline
\end{tabular}




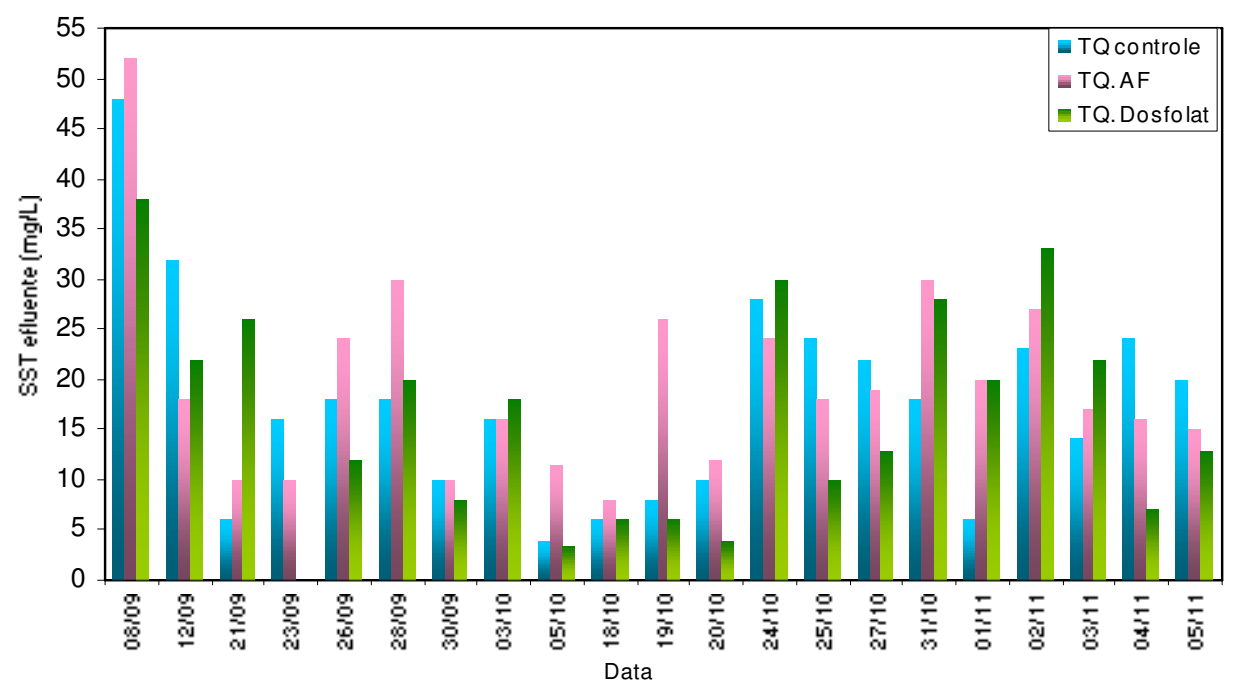

Figura 34 - Variação da concentração de sólidos em suspensão totais no efluente final dos reatores em função do tempo

Os resultados dos efluentes finais dos três reatores de lodos ativados estudados mostraram-se bem clarificados, apresentando baixas concentrações de sólidos em suspensão totais, refletido pelas boas características de sedimentabilidade, demonstradas através de ensaios de índice volumétrico de lodo (IVL), cujos resultados estão apresentados no Item 5.2.1.5. deste trabalho.

Porém, baseando-se nos resultados e nos valores médios obtidos durante o período operacional, é possível afirmar que não ocorreram diferenças na qualidade do efluente final dos reatores quanto à porção de sólidos em suspensão, mediante a adição de ácido fólico e de Dosfolat. 


\subsubsection{Demanda Química de Oxigênio (DQO)}

Os resultados relativos à DQO no efluente final dos sistemas com adição de ácido fólico e com Dosfolat, comparados ao controle, estão mostrados na Tabela 19, que apresenta os valores dos ensaios, representados na Figura 35, e as respectivas eficiências de remoção obtidas, mostradas na Figura 36.

Tabela 19 - Concentração de DQO no efluente dos reatores e respectiva eficiência de remoção

\begin{tabular}{|c|c|c|c|c|c|c|c|}
\hline \multirow{2}{*}{ № } & \multirow{2}{*}{ DATA } & \multicolumn{2}{|c|}{ TQ controle } & \multicolumn{2}{|c|}{ TQ. Ácido Fólico } & \multicolumn{2}{|c|}{ TQ. Dosfolat } \\
\hline & & $\mathrm{DQO}(\mathrm{mg} / \mathrm{L})$ & $\begin{array}{l}\text { Eficiência de } \\
\text { remoção (\%) }\end{array}$ & $\mathrm{DQO}$ (mg/L) & $\begin{array}{l}\text { Eficiência de } \\
\text { remoção (\%) }\end{array}$ & $\mathrm{DQO}(\mathrm{mg} / \mathrm{L})$ & $\begin{array}{l}\text { Eficiência de } \\
\text { remoção (\%) }\end{array}$ \\
\hline 1 & 09/09/05 & 60 & 91 & 68 & 90 & 36 & 94 \\
\hline 2 & $12 / 09 / 05$ & 75 & 88 & 48 & 93 & 40 & 94 \\
\hline 3 & $14 / 09 / 05$ & 47 & 93 & 42 & 94 & 50 & 93 \\
\hline 4 & $23 / 09 / 05$ & 31 & 95 & 35 & 95 & 39 & 94 \\
\hline 5 & $28 / 09 / 05$ & 19 & 97 & 23 & 96 & 27 & 96 \\
\hline 6 & $30 / 09 / 05$ & 12 & 98 & 8 & 99 & 4 & 99 \\
\hline 7 & 03/10/05 & 27 & 98 & 29 & 96 & 35 & 95 \\
\hline 8 & 05/10/05 & 16 & 98 & 16 & 98 & 12 & 98 \\
\hline 9 & $18 / 10 / 05$ & 34 & 95 & 41 & 94 & 39 & 94 \\
\hline 10 & 19/10/05 & 23 & 96 & 35 & 95 & 29 & 95 \\
\hline 11 & $21 / 10 / 05$ & 17 & 97 & 22 & 97 & 29 & 95 \\
\hline 12 & $24 / 10 / 05$ & 29 & 96 & 29 & 95 & 35 & 95 \\
\hline 13 & $25 / 10 / 05$ & 21 & 97 & 14 & 98 & 26 & 96 \\
\hline 14 & $27 / 10 / 05$ & 20 & 97 & 14 & 98 & 25 & 96 \\
\hline 15 & $31 / 10 / 05$ & 43 & 93 & 33 & 95 & 41 & 94 \\
\hline 16 & $01 / 11 / 05$ & 8 & 99 & 6 & 99 & 5 & 99 \\
\hline 17 & $02 / 11 / 05$ & 18 & 97 & 24 & 96 & 29 & 96 \\
\hline 18 & 03/11/05 & 20 & 97 & 32 & 95 & 26 & 96 \\
\hline 19 & $04 / 11 / 05$ & 5 & 99 & 6 & 99 & 7 & 99 \\
\hline 20 & 05/11/05 & 10 & 98 & 22 & 97 & 26 & 96 \\
\hline \multicolumn{2}{|c|}{ MÉDIA } & 27 & 96 & 27 & 96 & 28 & 96 \\
\hline \multicolumn{2}{|c|}{ MÁXIMO } & 75 & 99 & 68 & 99 & 50 & 99 \\
\hline \multicolumn{2}{|c|}{ MÍNIMO } & 5 & 88 & 6 & 90 & 4 & 93 \\
\hline \multicolumn{2}{|c|}{ DESVIO PADRÃO } & 17 & 3 & 15 & 2 & 12 & 2 \\
\hline
\end{tabular}




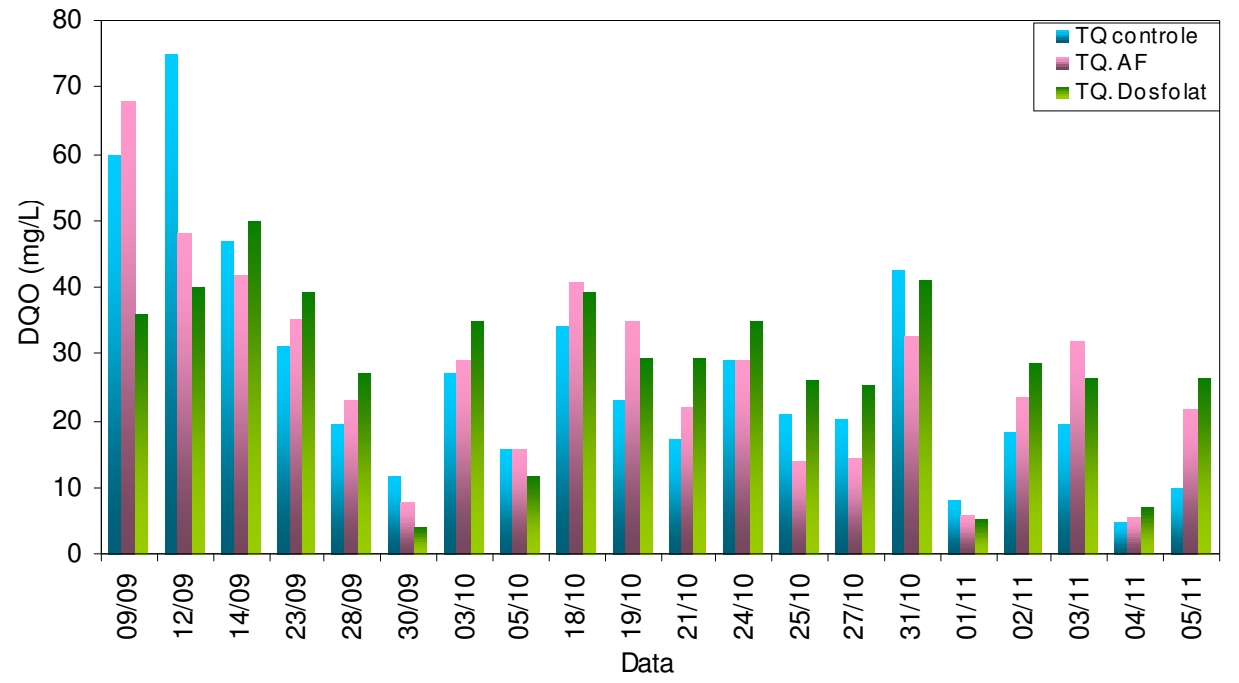

Figura 35 - Concentração de DQO no efluente final dos reatores

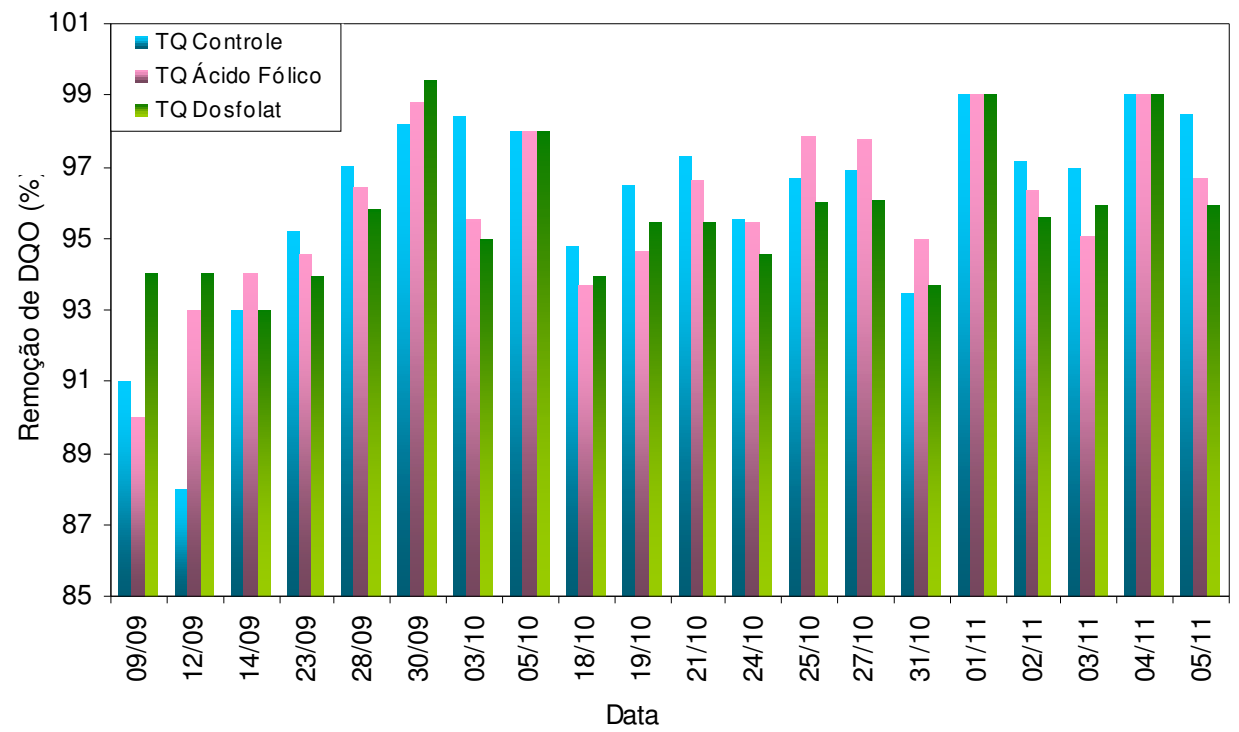

Figura 36 - Variação da eficiência de remoção de DQO (\%) no efluente final dos reatores durante o período de operação

A eficiência de remoção de DQO do lodo dos reatores com adição de ácido fólico e de Dosfolat, comparadas à do reator controle, foi praticamente a mesma, uma vez que durante todo o período de operação os resultados dos efluentes finais dos três reatores apresentaram-se muito próximos, tendo eficiência média de remoção de DQO de $96 \%$. 


\subsubsection{Demanda Bioquímica de Oxigênio (DBO)}

A realização dos testes de DBO previstos na metodologia desta pesquisa, segundo a programação de análises a serem feitas semanalmente, foi impossibilitada devido um problema técnico que ocorreu com o oxímetro específico para o teste de DBO, disponível no Laboratório de Saneamento da Escola Politécnica da USP. Assim, foram efetuados testes de DBO somente com amostras representativas de 3 semanas, as quais foram paralelamente submetidas à análise de DQO, cujos resultados dos ensaios, eficiências de remoção e relação DBO/DQO estão apresentados na Tabela 20.

Tabela 20 - Resultados de DBO x DQO dos efluentes dos reatores, e respectivas eficiências de remoção

\begin{tabular}{|c|c|c|c|c|c|c|}
\hline \multirow{2}{*}{ DATA } & \multirow{2}{*}{ REATOR } & \multicolumn{2}{|c|}{ DBO } & \multicolumn{2}{|c|}{ DQO } & \multirow{2}{*}{$\begin{array}{l}\text { RELAÇÃO } \\
\text { DBO/DQO }\end{array}$} \\
\hline & & $\begin{array}{c}\text { Concentração } \\
(\mathrm{mg} / \mathrm{L})\end{array}$ & Eficiência (\%) & $\begin{array}{c}\text { Concentração } \\
(\mathrm{mg} / \mathrm{L})\end{array}$ & Eficiência (\%) & \\
\hline \multirow{3}{*}{ 08/09/05 } & TQ.1 & 24 & 92 & 60 & 92 & 0,4 \\
\hline & TQ. 2 & 28 & 91 & 68 & 90 & 0,4 \\
\hline & TQ. 3 & 20 & 93 & 36 & 95 & 0,6 \\
\hline \multirow{3}{*}{$21 / 10 / 05$} & TQ.1 & 15 & 95 & 17 & 97 & 0,9 \\
\hline & TQ. 2 & 18 & 94 & 22 & 97 & 0,8 \\
\hline & TQ. 3 & 15 & 95 & 29 & 95 & 0,5 \\
\hline \multirow{3}{*}{ 27/10/05 } & TQ.1 & 15 & 95 & 21 & 97 & 0,7 \\
\hline & TQ. 2 & 14 & 95 & 14 & 98 & 1,0 \\
\hline & TQ. 3 & 12 & 96 & 25 & 96 & 0,5 \\
\hline
\end{tabular}

Nota: $\mathrm{DQO}_{\text {afluente }}=713 \mathrm{mg} / \mathrm{L}$ e DBO ${ }_{\text {afluente }}=296 \mathrm{mg} / \mathrm{L}$ 


\subsubsection{Nitrato}

As concentrações de nitrato (N-NO3) no efluente final dos reatores com adição de ácido fólico e com Dosfolat, comparados ao controle, bem como os valores mínimo, máximo e médias, obtidos durante o período de operação dos reatores, estão aprentados na Tabela 21, e representados na Figura 31.

Tabela 21 - Concentração de nitrato (mg/L) no efluente final dos reatores

\begin{tabular}{lcccc}
\hline \multirow{2}{*}{ No } & DATA & \multicolumn{3}{c}{ NITRATO (mg/L N-NO3) } \\
\cline { 3 - 5 } & & TQ Controle & TQ. Ácido Fólico & TQ. Dosfolat \\
\hline 1 & $22 / 8$ & 39 & 41 & 42 \\
2 & $9 / 9$ & 46 & 42 & 47 \\
3 & $12 / 9$ & 51 & 44 & 53 \\
4 & $13 / 9$ & 46 & 48 & 50 \\
5 & $19 / 9$ & 58 & 38 & 56 \\
6 & $22 / 9$ & 70 & 50 & 61 \\
7 & $26 / 9$ & 68 & 36 & 54 \\
8 & $30 / 9$ & 63 & 46 & 57 \\
9 & $1 / 11$ & 63 & 38 & 60 \\
10 & $2 / 11$ & 55 & 39 & 58 \\
11 & $3 / 11$ & 58 & 38 & 52 \\
12 & $4 / 11$ & 50 & 36 & 50 \\
13 & $5 / 11$ & 48 & 39 & 51 \\
\hline MÉDIA & & 55 & 41 & 53 \\
MÁXIMO & & 70 & 50 & 61 \\
MÍNIMO & & 39 & 36 & 42 \\
DESVIO PADRÃO & 9,0 & 4,4 & 5,1 \\
\hline
\end{tabular}




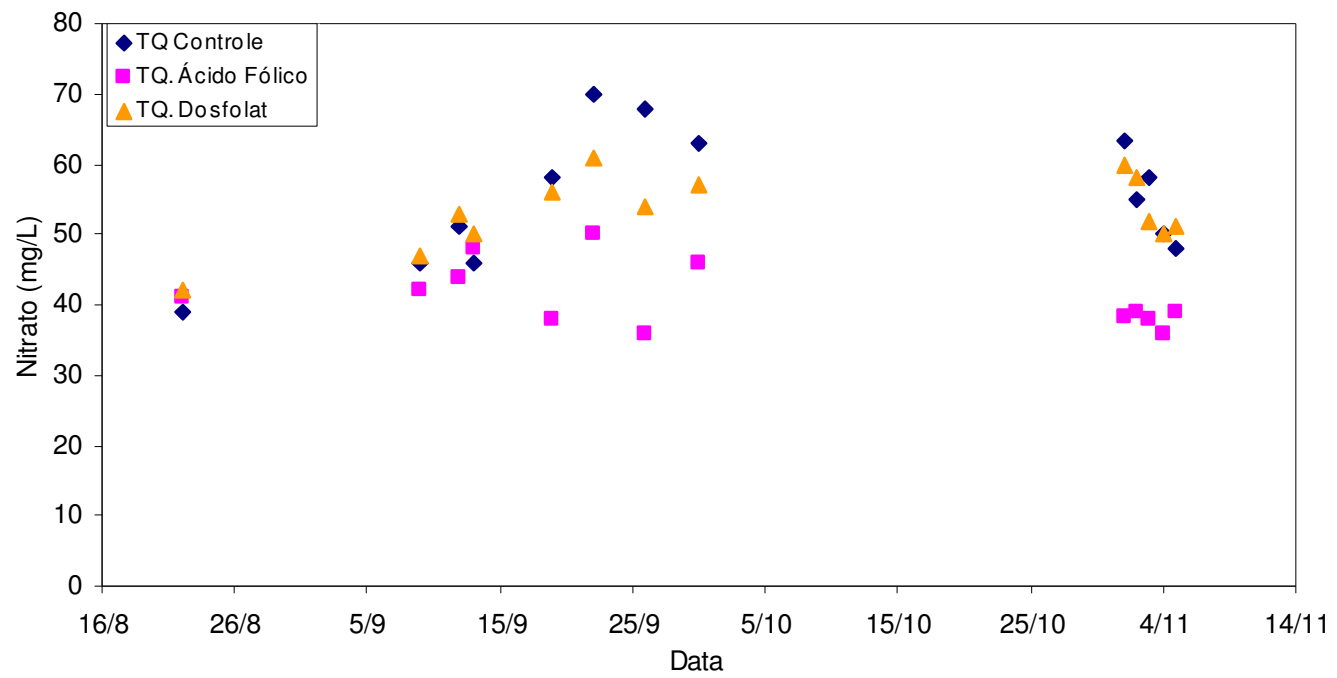

Figura 37 - Concentração de nitrato (mg/L) no efluente final dos reatores

O processo de nitrificação que ocorreu no lodo dos três reatores estudados foi eficiente, não sendo observadas diferenças entre as concentrações de nitrato nos efluentes finais nos reatores com adição de Dosfolat, que apresentou média de $53 \mathrm{mg} / \mathrm{L}$, comparados ao reator controle, cujo valor médio foi de $55 \mathrm{mg} / \mathrm{L}$.

O efluente final do reator com adição de ácido fólico apresentou as menores concentrações de nitrato, em relação aos outros reatores, $41 \mathrm{mg} / \mathrm{L}$, observadas em $85 \%$ das análises efetuadas. 


\subsubsection{Resultados relativos à sedimentabilidade do lodo}

Os resultados relativos ao índice volumétrico de lodo (IVL) e sua relação com as concentrações de sólidos em suspensão totais dos sistemas com ácido fólico, com Dosfolat e controle, estão apresentados na Tabela 22, que apresenta também os valores médios, máximos e mínimos. As determinações de IVL estão representadas na Figura 38.

Tabela 22 - Índice volumétrico de lodo (IVL) e relação com SSTA dos reatores durante o ensaio

\begin{tabular}{|c|c|c|c|c|c|c|c|}
\hline \multirow{3}{*}{ № } & \multirow{3}{*}{ DATA } & \multicolumn{6}{|c|}{ IVL $\times$ SSTA } \\
\hline & & \multicolumn{2}{|c|}{ TQ controle } & \multicolumn{2}{|c|}{ TQ. AF } & \multicolumn{2}{|c|}{ TQ. Dosfolat } \\
\hline & & $\mathrm{IVL}(\mathrm{mL} / \mathrm{L})$ & SSTA (mg/L) & $\mathrm{IVL}(\mathrm{mL} / \mathrm{L})$ & SSTA (mg/L) & $\mathrm{IVL}(\mathrm{mL} / \mathrm{L})$ & $\mathrm{SSTA}(\mathrm{mg} / \mathrm{L})$ \\
\hline 1 & 06/09/05 & 79 & 1652 & 74 & 1618 & 79 & 1640 \\
\hline 2 & 08/09/05 & 70 & 1434 & 71 & 1408 & 74 & 1360 \\
\hline 3 & $12 / 09 / 05$ & 82 & 1224 & 79 & 1258 & 76 & 1314 \\
\hline 4 & $14 / 09 / 05$ & 73 & 1368 & 72 & 1382 & 73 & 1372 \\
\hline 5 & $19 / 09 / 05$ & 76 & 1570 & 78 & 1468 & 76 & 1586 \\
\hline 6 & $21 / 09 / 05$ & 85 & 1300 & 83 & 1212 & 76 & 1406 \\
\hline 7 & 23/09/05 & 80 & 1504 & 76 & 1452 & 78 & 1536 \\
\hline 8 & 26/09/05 & 77 & 1434 & 68 & 1474 & 73 & 1506 \\
\hline 9 & 28/09/05 & 73 & 1502 & 66 & 1504 & 75 & 1472 \\
\hline 10 & 30/09/05 & 68 & 1474 & 70 & 1434 & 69 & 1440 \\
\hline 11 & 03/10/05 & 71 & 1550 & 68 & 1478 & 72 & 1528 \\
\hline 12 & 05/10/05 & 94 & 900 & 97 & 1087 & 76 & 1311 \\
\hline 13 & $18 / 10 / 05$ & 56 & 1526 & 74 & 1426 & 77 & 1428 \\
\hline 14 & $19 / 10 / 05$ & 66 & 1808 & 67 & 1794 & 68 & 1628 \\
\hline 15 & $20 / 10 / 05$ & 60 & 1676 & 69 & 1596 & 70 & 1582 \\
\hline 16 & $24 / 10 / 05$ & 63 & 1920 & 65 & 1846 & 66 & 1806 \\
\hline 17 & $25 / 10 / 05$ & 68 & 1754 & 65 & 1844 & 67 & 1780 \\
\hline 18 & $26 / 10 / 05$ & 60 & 2000 & 60 & 2002 & 62 & 1926 \\
\hline 19 & $31 / 10 / 05$ & 65 & 1848 & 65 & 1846 & 66 & 1830 \\
\hline 20 & $01 / 11 / 05$ & 59 & 1856 & 58 & 1892 & 58 & 1886 \\
\hline
\end{tabular}




\begin{tabular}{|c|c|c|c|c|c|c|c|}
\hline \multirow{3}{*}{ № } & \multirow{3}{*}{ DATA } & \multicolumn{6}{|c|}{ IVL $\times$ SSTA } \\
\hline & & \multicolumn{2}{|c|}{ TQ controle } & \multicolumn{2}{|c|}{ TQ. AF } & \multicolumn{2}{|c|}{ TQ. Dosfolat } \\
\hline & & $\mathrm{IVL}(\mathrm{mL} / \mathrm{L})$ & SSTA (mg/L) & $\mathrm{IVL}(\mathrm{mL} / \mathrm{L})$ & SSTA (mg/L) & $\mathrm{IVL}(\mathrm{mL} / \mathrm{L})$ & SSTA (mg/L) \\
\hline 21 & 02/11/05 & 62 & 1784 & 58 & 1892 & 65 & 1700 \\
\hline 22 & 03/11/05 & 64 & 1714 & 58 & 1892 & 63 & 1738 \\
\hline 23 & 04/11/05 & 59 & 1864 & 59 & 1854 & 61 & 1796 \\
\hline 24 & 05/11/05 & 56 & 1952 & 58 & 1888 & 58 & 1884 \\
\hline \multicolumn{2}{|c|}{ MÉDIA } & 60 & 1829 & 58 & 1882 & 62 & 1780 \\
\hline \multicolumn{2}{|c|}{ MÁXIMO } & 64 & 1952 & 59 & 1892 & 65 & 1884 \\
\hline \multicolumn{2}{|c|}{ MÍNIMO } & 56 & 1714 & 58 & 1854 & 58 & 1700 \\
\hline \multicolumn{2}{|c|}{ DESVIO PADRÃO } & 3 & 89 & 1 & 16 & 2 & 69 \\
\hline
\end{tabular}

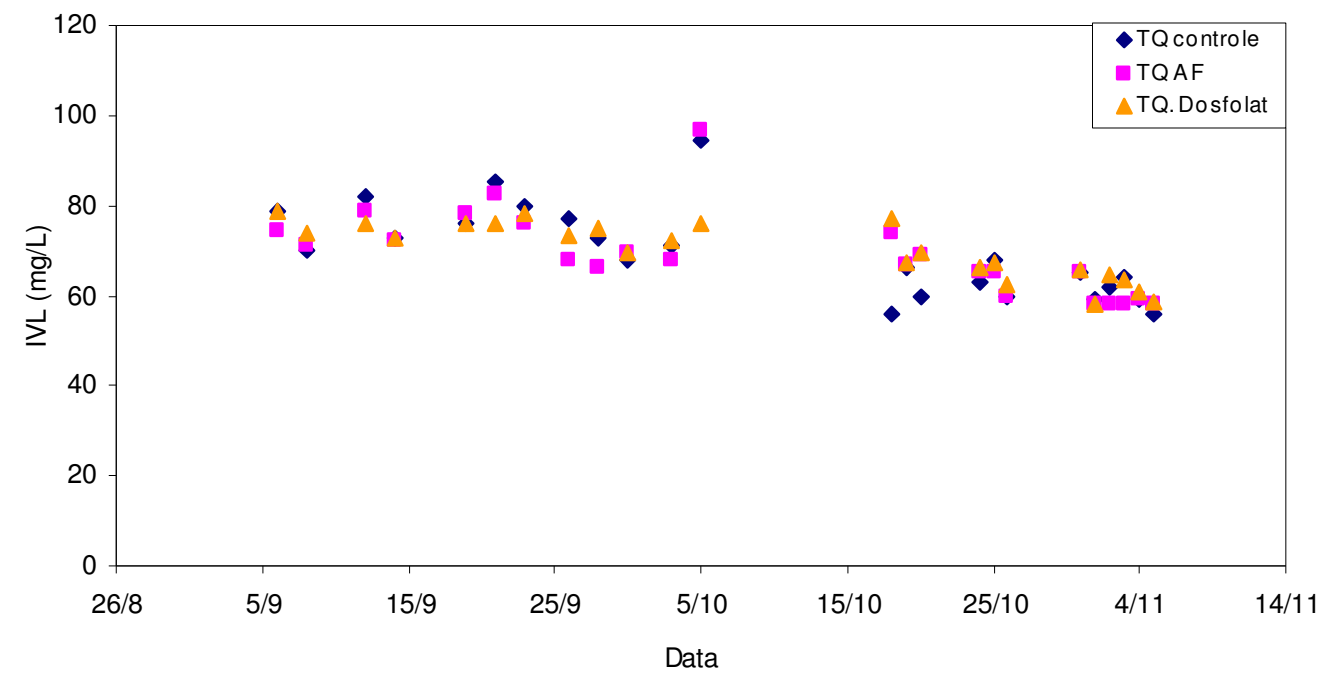

Figura 38 - Variação do índice volumétrico de lodo (IVL) dos reatores no decorrer do período

O lodo dos três reatores estudados apresentaram boas características de sedimentabilidade, sendo determinadas através de ensaios de índice volumétrico de lodo, cujos resultados mostraram que não ocorreram diferenças entre eles, mantendo-se com valores muito próximos durante todo o período de operação, com média de $69 \mathrm{ml} / \mathrm{L}$ no lodo dos reatores controle e com ácido fólico e de $70 \mathrm{ml} / \mathrm{L}$ no reator com Dosfolat. 


\subsubsection{Resultados relativos às determinações de microbiologia}

\subsubsection{Tamanho dos flocos biológicos}

Os resultados da avaliação qualitativa do tamanho médio dos flocos biológicos do lodo dos retores com adição de ácido fólico e de Dosfolat, comparados ao controle, estão apresentados na Tabela 23 e representados na Figura 39.

Tabela 23 - Variação do tamanho ( $\mu \mathrm{m})$ dos flocos biológicos do lodo dos reatores no decorrer do período

\begin{tabular}{cccc}
\hline \multirow{2}{*}{ DATA } & \multicolumn{3}{c}{ TAMANHO DOS FLOCOS $(\mu \mathrm{m})$} \\
\cline { 2 - 4 } & TQ Controle & TQ Ácido Fólico & TQ Dosfolat \\
\hline $13 / 9$ & 221 & 177 & 173 \\
$19 / 9$ & 160 & 187 & 190 \\
$26 / 9$ & 143 & 163 & 173 \\
$28 / 9$ & 174 & 221 & 234,6 \\
$3 / 10$ & 222 & 214 & 299 \\
$5 / 10$ & 215 & 223 & 251 \\
$18 / 10$ & 174 & 211 & 235 \\
$20 / 10$ & 166 & 185 & 189 \\
$24 / 10$ & 163 & 197 & 202 \\
$27 / 10$ & 186 & 219 & 238 \\
31/10 & 149 & 264 & 230 \\
2/11 & 118 & 235 & 250 \\
3/11 & 125 & 257 & 214 \\
5/11 & 123 & 253 & 243 \\
\hline MÉDIA & 167 & 215 & 223 \\
MÁXIMO & 222 & 264 & 299 \\
MÍNIMO & 118 & 163 & 173 \\
DESVIO PADRÃO & 34,7 & 30,6 & 35,0 \\
\hline
\end{tabular}




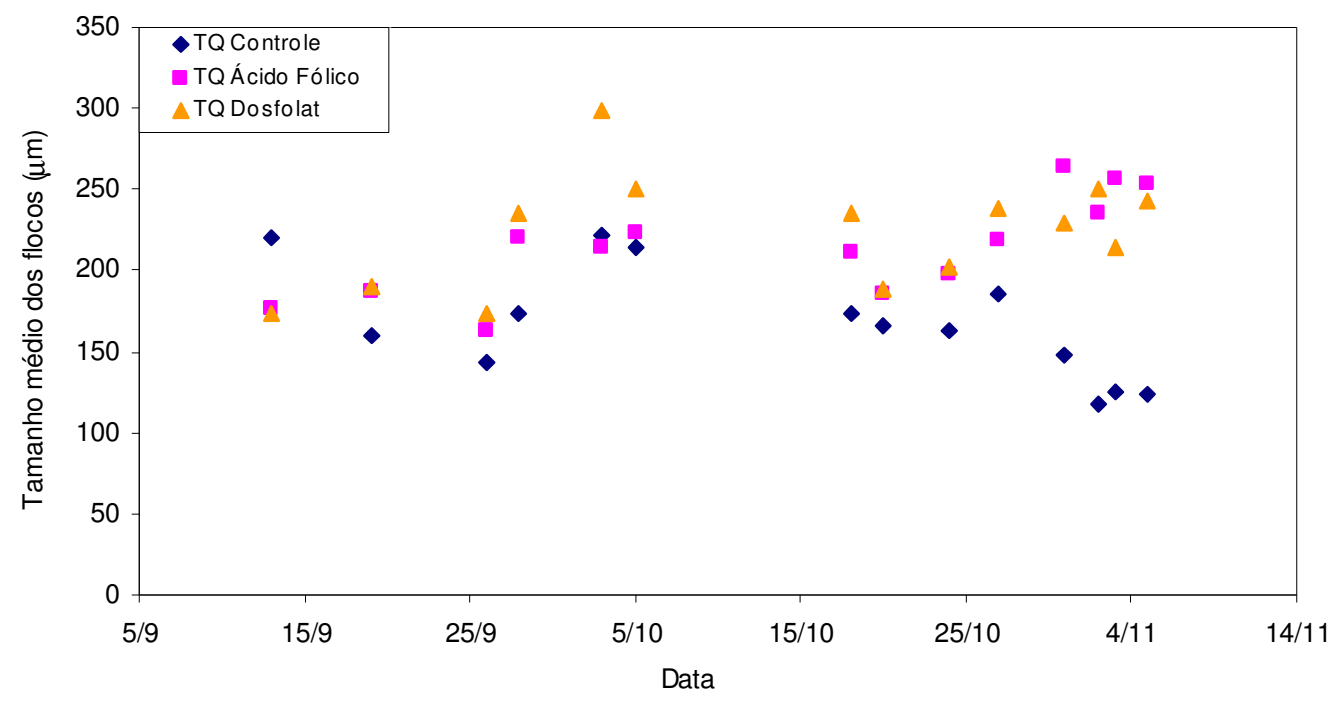

Figura 39 - Variação do tamanho médio dos flocos biológicos do lodo dos reatores

Os flocos biológicos do lodo do reator com adição de Dosfolat apresentaram tamanhos superiores em relação aos dos reatores com ácido fólico e controle - em média $223 \mu \mathrm{m}$, sendo ligeiramente próximos do tamanho médio dos flocos do reator com ácido fólico - $215 \mu \mathrm{m}$. O reator controle apresentou flocos com tamanho médio de $167 \mu$ m. Assim, a partir desta tendência de maior crescimento, sugere-se que a adição de ambas as soluções favorece as bactérias dos flocos e a formação destes, em detrimento às bactérias livres.

Os tamanhos médios dos flocos dos três reatores apresentam valores dentro da faixa considerada como tamanho médio a grande, típica de lodos ativados tratando esgoto sanitário, e indicativo de lodo com boas condições, segundo Vazoller (1989).

Após o período de 60 dias de inoculação de lodo nos reatores, com condições mais estáveis, considerou-se que os organismos estavam adaptados à alimentação com substrato sintético, a partir do qual teve início a adição das soluções de ácido fólico e da composto Dosfolat nos reatores. A partir do $14^{\circ}$ dia de aplicação destes (19/09/05), observou-se que os flocos do lodo dos dois reatores contendo as soluções começaram a apresentar tamanhos superiores em relação aos do reator controle, permanecendo assim até o final da operação. 


\subsubsection{Comprimento das bactérias filamentosas no lodo dos reatores}

Os resultados dos exames microscópicos do comprimento total de bactérias filamentosas presentes no lodo dos reatores estão apresentados na Tabela 24 e na Figura 40.

Tabela 24 - Comprimento total das filamentosas $(\mu \mathrm{m} / \mathrm{L})$ presentes no lodo dos reatores

\begin{tabular}{|c|c|c|c|c|}
\hline \multirow{2}{*}{ DATA } & \multirow{2}{*}{ DIA DO ENSAIO } & \multicolumn{3}{|c|}{ COMPRIMENTO DE FILAMENTOSAS $(\mu \mathrm{m} / \mathrm{mL})$} \\
\hline & & TQ. Controle & TQ. AF & TQ. Dosfolat \\
\hline $29 / 9$ & 24 & $1,5 \times 10^{6}$ & $1,6 \times 10^{6}$ & $2,5 \times 10^{6}$ \\
\hline $18 / 10$ & 43 & $1,1 \times 10^{6}$ & $6,1 \times 10^{5}$ & $9,7 \times 10^{5}$ \\
\hline $20 / 10$ & 45 & $1,3 \times 10^{6}$ & $1,4 \times 10^{6}$ & $1,2 \times 10^{6}$ \\
\hline $24 / 10$ & 49 & $1,3 \times 10^{6}$ & $1,4 \times 10^{6}$ & $5,7 \times 10^{5}$ \\
\hline $27 / 10$ & 52 & $1,7 \times 10^{6}$ & $1,3 \times 10^{6}$ & $1,2 \times 10^{6}$ \\
\hline $31 / 10$ & 56 & $3,8 \times 10^{4}$ & $4,8 \times 10^{3}$ & $4,1 \times 10^{4}$ \\
\hline $2 / 11$ & 58 & $1,6 \times 10^{6}$ & $1,2 \times 10^{6}$ & $2,4 \times 10^{6}$ \\
\hline $3 / 11$ & 59 & $2,3 \times 10^{6}$ & $2,1 \times 10^{6}$ & $2,0 \times 10^{6}$ \\
\hline $5 / 11$ & 60 & $2,8 \times 10^{6}$ & $1,3 \times 10^{6}$ & $2,0 \times 10^{6}$ \\
\hline \multicolumn{2}{|c|}{ MÉDIA } & $1,5 \times 10^{6}$ & $1,2 \times 10^{6}$ & $1,4 \times 10^{6}$ \\
\hline \multicolumn{2}{|c|}{ MÁXIMO } & $2,8 \times 10^{6}$ & $2,1 \times 10^{6}$ & $2,5 \times 10^{6}$ \\
\hline \multicolumn{2}{|c|}{ MÍNIMO } & $3,8 \times 10^{4}$ & $4,8 \times 10^{3}$ & $4,1 \times 10^{4}$ \\
\hline \multicolumn{2}{|c|}{ DESVIO PADRÃO } & $7,8 \times 10^{5}$ & $5,88 \times 10^{5}$ & $8,55 \times 10^{5}$ \\
\hline
\end{tabular}




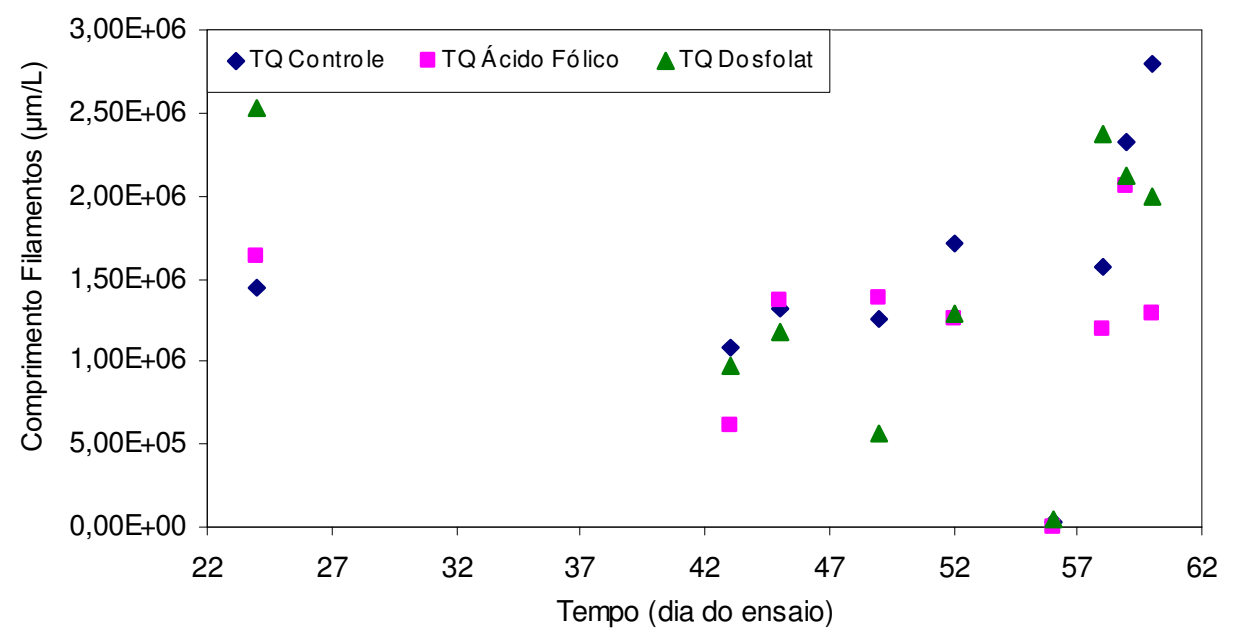

Figura 40 - Comprimento total das bactérias filamentosas $(\mu \mathrm{m} / \mathrm{L})$ presentes no lodo dos reatores

Os dados mostram que não houveram diferenças no lodo dos reatores com ácido fólico, com Dosfolat e controle. Assim, tanto o ácido fólico como o Dosfolat não influenciaram a dinâmica do crescimento de bactérias filamentosas, que mantiveram-se em baixa densidade, apresentando 1 a 5 filamentos por floco no lodo dos três reatores durante todo o período de operação. 


\subsubsection{Observações dos exames microscópicos dos sistemas de lodos ativados}

A Tabela 25 apresenta os resultados dos exames microscópicos realizados durante o período de operação dos reatores controle, com adição de ácido fólico grau analítico e com a adição do composto Dosfolat, sendo os primeiros 60 dias sem adição dos mesmos, para estabilizaç

Tabela 25 - Resultados dos exames microscópicos dos lodos ativados dos reatores controle, com adição de ácido fólico e com adição do composto Dosfolat

continua

\begin{tabular}{|c|c|c|c|c|}
\hline DIA & DATA & REATOR CONTROLE & REATOR COM A.F. & REATOR COM DOSFOLAT \\
\hline 1 & $\begin{array}{c}\text { 06/07/05 } \\
\left(1^{\circ} \text { dia de }\right. \\
\text { operação dos } \\
\text { sistemas })\end{array}$ & $\begin{array}{l}\text { Flocos bem formados, com } \\
\text { poucas filamentosas (observada } \\
\text { somente em flocos ocasionais). } \\
\text { Microfauna pouco variada, com } \\
\text { presença de anelídeos, } \\
\text { Vorticella spp, Arcella sp, } \\
\text { Aspidisca sp, tardígrados }\end{array}$ & $\begin{array}{l}\text { Situação idêntica ao reator } \\
\text { Controle }\end{array}$ & $\begin{array}{l}\text { Situação idêntica ao reator } \\
\text { Controle }\end{array}$ \\
\hline 2 & $11 / 07 / 05$ & $\begin{array}{l}\text { Flocos bem formados, com } \\
\text { poucos filamentosas. Presença } \\
\text { de mais organismos, como } \\
\text { anelídeos, rotíferos, flagelados, } \\
\text { Vorticella spp, Arcella sp, } \\
\text { Aspidisca sp, tardígrados e } \\
\text { alguns fungos }\end{array}$ & $\begin{array}{l}\text { Situação idêntica ao reator } \\
\text { Controle }\end{array}$ & $\begin{array}{l}\text { Situação idêntica ao reator } \\
\text { Controle }\end{array}$ \\
\hline 3 & $14 / 07 / 05$ & $\begin{array}{l}\text { Situação estável, similar à data } \\
\text { anterior }\end{array}$ & $\begin{array}{l}\text { Situação estável, similar à data } \\
\text { anterior }\end{array}$ & $\begin{array}{l}\text { Situação estável, similar à data } \\
\text { anterior }\end{array}$ \\
\hline
\end{tabular}

Flocos bem formados, poucas filamentosas. Presença de

4 22/07/05 flagelados, rotíferos, Vaginicolla Arcella sp, Vorticella spp e anelídeos

\section{Situação idêntica ao reator \\ Situação idêntica ao reator} Controle Controle
Situação estável, similar à data anterior quanto à composição da

5 28/07/05 microfauna, mas com maior quantidade de filamentosas, que se projetam dos flocos
Situação idêntica ao reator Situação idêntica ao reator Controle Controle 
Tabela 25 - Resultados dos exames microscópicos dos lodos ativados dos reatores controle, com adição de ácido fólico e com adição do composto Dosfolat

continua

\begin{tabular}{lllll}
\hline DIA & DATA & REATOR CONTROLE & REATOR COM A.F. & REATOR COM DOSFOLAT \\
\hline 6 & $02 / 08 / 05$ & $\begin{array}{l}\text { Situação estável, similar à data } \\
\text { anterior }\end{array}$ & $\begin{array}{l}\text { Situação estável, similar à data } \\
\text { anterior }\end{array}$ & $\begin{array}{l}\text { Situação estável, similar à data } \\
\text { anterior }\end{array}$
\end{tabular}

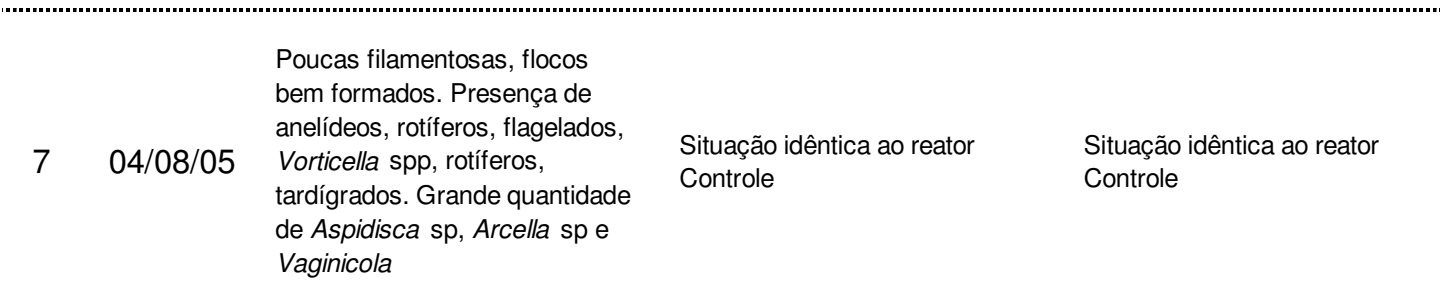

\begin{tabular}{|c|c|c|c|c|}
\hline 8 & 12/08/05 & $\begin{array}{l}\text { Flocos menos compactos, } \\
\text { sendo muitos difusos. } \\
\text { Filamentosas causando o efeito } \\
\text { de abrir a estrutura dos flocos. } \\
\text { Presença dos mesmos } \\
\text { organismos encontrados no } \\
\text { período anterior }\end{array}$ & $\begin{array}{l}\text { Situação estável, similar ao } \\
\text { período anterior }\end{array}$ & $\begin{array}{l}\text { Situação estável, similar ao } \\
\text { período anterior }\end{array}$ \\
\hline 9 & 15/08/05 & $\begin{array}{l}\text { Poucas filamentosas, flocos } \\
\text { bem formados. Presença de } \\
\text { Vorticella spp, Aspidisca sp, } \\
\text { Epistylis spp, rotíferos, ciliados } \\
\text { livre-natantes, ciliados } \\
\text { predadores de flocos, Arcella } \\
\text { sp. Muitos Vaginicola }\end{array}$ & $\begin{array}{l}\text { Situação idêntica ao reator } \\
\text { Controle }\end{array}$ & $\begin{array}{l}\text { Situação idêntica ao reator } \\
\text { Controle }\end{array}$ \\
\hline 10 & 22/08/05 & $\begin{array}{l}\text { Flocos bem formados, com } \\
\text { poucas filamentosas. Presença } \\
\text { de flagelados, ciliados, rotíferos, } \\
\text { Arcella sp, Aspidisca sp, } \\
\text { Vorticella spp, anelídeos, } \\
\text { tardígrados, Epistylis spp. } \\
\text { Muitos Vaginicola }\end{array}$ & $\begin{array}{l}\text { Situação idêntica ao reator } \\
\text { Controle }\end{array}$ & $\begin{array}{l}\text { Situação idêntica ao reator } \\
\text { Controle }\end{array}$ \\
\hline
\end{tabular}

$1131 / 08 / 05$ Situação estável, similar à data $\begin{aligned} & \text { Situação estável, similar à data } \\ & \text { anterior }\end{aligned}$ anterior $\begin{aligned} & \text { Situação estável, similar à data } \\ & \text { anterior }\end{aligned}$


Tabela 25 - Resultados dos exames microscópicos dos lodos ativados dos reatores controle, com adição de ácido fólico e com adição do composto Dosfolat

continua

\begin{tabular}{lllll}
\hline DIA & DATA & REATOR CONTROLE & REATOR COM A.F. & REATOR COM DOSFOLAT \\
\hline 12 & $01 / 09 / 05$ & $\begin{array}{l}\text { Situação estável, similar ao } \\
\text { período anterior }\end{array}$ & $\begin{array}{l}\text { Situação estável, similar ao } \\
\text { período anterior }\end{array}$ & $\begin{array}{l}\text { Situação estável, similar ao } \\
\text { período anterior }\end{array}$
\end{tabular}

Poucos flocos compactos, sendo a maioria difusos.

Abundância de filamentosas maior (comumente observadas, mas não presente em todos os

13 06/09/05 flocos), abrindo a estrutura dos

(início da flocos. Presença de muitos
dição de ácido flagelados pequenos, rotíferos,

fólico e ciliados, Vaginicola, Aspidisca

Dosfolat) sp, Vorticella spp, flagelados, Arcella sp e tardígrados

$\begin{array}{ll}\text { Situação idêntica ao reator } & \begin{array}{l}\text { Situação idêntica ao reator } \\ \text { Controle }\end{array}\end{array}$

Poucos flocos compactos, sendo a maioria difusos. Mesma abundância de filamentos da data anterior. Presença de ciliados livre-natantes, rotíferos, 14 12/09/05 ciliados livre-natantes e Situação idêntica ao reator predadores de flocos, Controle Vaginicola, Aspidisca sp, Vorticella spp (menor quantidade que período anterior), flagelados, Arcella sp e anelídeos

Situação idêntica ao reator Controle, mas verificada a presença de alguns fungos

15 19/09/05 $\begin{array}{lll}\text { Situação estável, similar ao } & \begin{array}{l}\text { Situação idêntica ao reator } \\ \text { período anterior }\end{array} & \begin{array}{l}\text { Situação idêntica ao reator } \\ \text { Controle }\end{array}\end{array}$

Os flocos ficaram mais compactos, e filamentosas voltaram a desempenhar o efeito de construção na estrutura

16 22/09/05 destes. Presença de Vorticella spp, anelídeos, rotíferos,

Situação idêntica ao reator Controle tardígrados, Arcella sp, ciliados livres-natantes 
Tabela 25 - Resultados dos exames microscópicos dos lodos ativados dos reatores controle, com adição de ácido fólico e com adição do composto Dosfolat

continua

\begin{tabular}{lllll}
\hline DIA & DATA & REATOR CONTROLE & REATOR COM A.F. & REATOR COM DOSFOLAT \\
\hline 17 & $\begin{array}{l}\text { Flocos bem formados, poucas } \\
\text { filamentosas. Presença de } \\
\text { rotíferos, Vaginicola, ciliado livre- } \\
\text { natante (longo), Arcella sp, } \\
\text { Vorticella spp, anelídeos e } \\
\text { tardígrados }\end{array}$ & $\begin{array}{l}\text { Situação idêntica ao reator } \\
\text { Controle }\end{array}$ & $\begin{array}{l}\text { Situação idêntica ao reator } \\
\text { Controle, mas verificada a } \\
\text { presença de Vorticella }\end{array}$ \\
\end{tabular}

18 28/09/05 $\begin{array}{lll}\text { Situação estável, similar ao } & \begin{array}{l}\text { Situação estável, similar ao } \\ \text { período anterior }\end{array} & \begin{array}{l}\text { Situação estável, similar ao } \\ \text { período anterior }\end{array}\end{array}$

Parte dos flocos compactos e outra parte difusos. Filamentos comumente observados, mas não em todos os flocos.

19 29/09/05 Presença de ciliados livrenatantes, rizópodes (Arcella sp e Euglypha), rotíferos, anelídeos, Vaginicola, Vorticella spp (poucas). Presença da filamentosa Nocardia spp

$\begin{array}{ll}\text { Situação idêntica ao reator } & \begin{array}{l}\text { Situação idêntica ao reator } \\ \text { Controle }\end{array}\end{array}$

Controle

Maioria dos flocos mais compactos e maiores (médios, maior tamanho verificado durante todo o período - 222

Flocos com mesmas características do reator controle, e com tamanho de 214 $\mu \mathrm{m}$. Presença dos mesmos organismos do reator controle
Flocos maiores (médios, e foi o maior tamanho verificado durante todo o período - 299 $\mu \mathrm{m})$. Presença dos mesmos organismos do reator controle. Nocardia spp, rotíferos, Arcella $\mathrm{sp}$, Aspidisca sp, Vaginicola e anelídeos

Flocos bem formados, e filamentos comumente observados (mas não presente em todos os flocos). Presença de grandes ciliados livres (entre

21 18/10/05 eles Blepharisma), Arcella sp, rotíferos (Epiphanes, Lecane), Vaginicola, Aspidisca sp, Litonotus fasciola, Euglypha, Centropyxis, ameba, tardígrado, anelídeos

$\begin{array}{ll}\text { Situação idêntica ao reator } & \begin{array}{l}\text { Situação idêntica ao reator } \\ \text { Controle }\end{array} \\ \text { Controle }\end{array}$

Situação
Controle 
Tabela 25 - Resultados dos exames microscópicos dos lodos ativados dos reatores controle, com adição de ácido fólico e com adição do composto Dosfolat

continua

\begin{tabular}{|c|c|c|c|c|}
\hline DIA & DATA & REATOR CONTROLE & REATOR COM A.F. & REATOR COM DOSFOL \\
\hline 22 & $20 / 10 / 05$ & $\begin{array}{l}\text { Flocos e filamentosas com as } \\
\text { mesmas características da data } \\
\text { anterior. Presença de rotíferos, } \\
\text { tardígrado, ciliados livre- } \\
\text { natantes, Vaginicola, Arcella sp, } \\
\text { Centropyxis e Vorticella spp } \\
\text { (muito poucos) }\end{array}$ & $\begin{array}{l}\text { Situação idêntica ao reator } \\
\text { Controle }\end{array}$ & $\begin{array}{l}\text { Situação idêntica ao reator } \\
\text { Controle }\end{array}$ \\
\hline
\end{tabular}

Flocos bem formados, com

poucas filamentosas,

observadas em flocos

ocasionais. Presença de mais Mesmas características do

23 24/10/05 organismos, como anelídeos, reator Controle, e também

rotíferos, grandes ciliados livres, observada a presença de um

Situação idêntica ao reator

flagelados, Vorticella spp,

nematóide e de um fungo

Controle

Arcella sp, Aspidisca sp,

Vaginicola, Euglypha,

Centropyxis, tardígrado

Flocos bem formados,

filamentosas somente

observadas em flocos

ocasionais. Presença de

$24 \quad 27 / 10 / 05$

Aspidisca sp, Arcella sp

(muitas), rotíferos, anelídeos,

tardígrado, Vaginicola, grandes

Controle

Situação idêntica ao reator

Controle, e também com

ciliados livres (muitos),

Vorticella, Centropyxis,

Euglypha, anelídeos, oligogueta

$\begin{array}{ll}\text { Situação idêntica ao reator } & \begin{array}{l}\text { Situação idêntica ao reator } \\ \text { Controle, e também com } \\ \text { Controle }\end{array} \\ \text { presença de alguns flagelados }\end{array}$

$2531 / 10 / 05 \quad \begin{array}{lll}\text { Situação estável, similar ao } & \begin{array}{l}\text { Situação estável, similar ao } \\ \text { período anterior }\end{array} & \begin{array}{l}\text { Situação estável, similar ao } \\ \text { período anterior }\end{array}\end{array}$

Flocos bem formados, quantidade um pouco maior de

26 02/11/05 filamentosas, sendo comumente

Mesmas características do reator Controle

Mesmas características do em todos os flocos. Microfauna sem alterações. reator Controle

\section{03/11/05 Situação estável, similar ao período anterior}

Situação estável, similar ao período anterior
Situação estável, similar ao período anterior 
Tabela 25 - Resultados dos exames microscópicos dos lodos ativados dos reatores controle, com adição de ácido fólico e com adição do composto Dosfolat

continua

\begin{tabular}{lllll}
\hline DIA & DATA & REATOR CONTROLE & REATOR COM A.F. & REATOR COM DOSFOLAT \\
\hline & & & \\
28 & $05 / 11 / 05$ & $\begin{array}{l}\text { Situação estável, similar ao } \\
\text { período anterior }\end{array}$ & $\begin{array}{l}\text { Situação estável, similar ao } \\
\text { período anterior }\end{array}$ & $\begin{array}{l}\text { Situação estável, similar ao } \\
\text { período anterior }\end{array}$
\end{tabular}

NOTA:

- Flocos bem formados - com boas características de morfologia, sendo firmes, compactos e geralmente com forma arredondada, e com tamanho de médios a grandes ( 150 a $500 \mu \mathrm{m})$.

- A microfauna manteve-se pouco variada e pouco abundante, não havendo predominância de grupo ou gênero sobre os demais.

Pelos resultados dos exames microscópicos, é possível concluir que nas condições experimentais estabelecidas não houveram diferenças na composição e variação da microfauna dos três reatores. Ficou evidente que no decorrer do período de operação os flocos do lodo dos reatores que receberam adição de ácido fólico e Dosfolat apresentaram melhores características, em relação ao tamanho, forma e estrutura.

Não ocorreram variações da diversidade de bactérias filamentosas no lodo dos três reatores, sendo verificada a presença e distribuição equilibrada das mesmas espécies durante o período de operação. As mais comumente encontradas foram Sphaerotilus Natans, Haliscomenobacter hydrossis, Nostocoida Limicola, Tipo 021 N, Tipo 0041. E menos freqüente, foram encontradas Thiothrix I e Nocardia spp. Todas estas espécies encontradas estão entre as de ocorrência comum em sistemas de lodos ativados, tal como já apresentado nas Figuras 3 e 4 deste trabalho. 


\subsubsection{Aspectos da microbiologia de lodos ativados apresentados como resultados de pesquisas que aplicaram ácido fólico e Dosfolat em reatores destes sistemas}

A Tabela 26 apresenta os resultados das observações de microscópicos realizados por outros autores que também estudaram a influência da aplicação de ácido fólico e/ou de Dosfolat em reatores de lodos ativados.

Tabela 26 - Aspectos da microbiologia do lodo relatados em outras pesquisas como resultados da aplicação de ácido fólico e de Dosfolat em reatores de lodos ativados

AUTORES

CONSIDERAÇÕES SOBRE OS RESULTADOS EM RELAÇÃO À MICROBIOTA DOS REATORES COM ADIÇÃO DE ÁCIDO FÓLICO E DOSFOLAT

Anderl, 1987 Contribuição na otimização do tratamento biológico e na redução da geração de lodo excedente.

Alphachemie, 1988

A adição do composto Dosfolat promoveu a aceleração do metabolismo no lodo do reator de lodos ativados, maior estabilidade da estação de tratamento e mair resistência à choques tóxicos (verificada a partir do recebimento de efluentes com penicilina, laurilsulfato e tiofenol).

Aumento da diversidade, população e atividade dos microrganismos. Com relação a esta último, o autor sugere que o metabolismo se torna mais elevado, conduzindo a

Ostrander, 1992 uma maior eficiência do tratamento.

A adição de ácido fólico conduziu a uma menor produção de lodo, e melhor sedimentação (possibilitando um efluente mais clarificado). Estas características foram confirmadas pelos resultados, em que se observou no efluente final a redução de sólidos em suspensão, DBO e DQO.

Aumento da atividade da biomassa, crescimento mais diversificado da microbiota, especialmente da população de protozoários. Redução do crescimento de bactérias

Akerboom et al., filamentosas e melhora da floculação. Maior quantidade de grandes ciliados e de 1994 rotíferos. Aumento da respiração endógena, e menor quantidade de sólidos no lodo (menor velocidade de crescimento). Melhor sedimentabilidade do lodo, com efluente 50 a $70 \%$ mais clarificado e significante redução da quantidade de lodo gerado. 
Tabela 26 - Aspectos da microbiologia do lodo relatados em outras pesquisas como resultados da aplicação de ácido fólico e de Dosfolat em reatores de lodos ativados

AUTOR

Conchon, 1998
CONSIDERAÇÕES SOBRE OS RESULTADOS EM RELAÇÃO À MICROBIOTA DOS REATORES COM ADIÇÃO DE ÁCIDO FÓLICO E DOSFOLAT

Aumento da diversidade, população e atividade dos microrganismos componentes da microfauna; controla o crescimento de bactérias filamentosas, formação de flocos maiores e mais compactos, melhorando assim as características de sedimentabilidade do lodo. Predominância de bactérias formadoras de flocos, aumento da taxa de respiração, aumento da concentração de sólidos no reator biológico.

Aumento da eficiência de remoção da matéria orgânica (remoção de DQO de 85 a 93\% e redução de DBO acima de 95\%).

Senörer, 2001

Verificado um aumento significativo da eficiência do tratamento, sobretudo na remoção de DQO, comparativamente à operação sem adição de ácido fólico.

Observou-se menor crescimento de filamentosas, minimizando problemas de intumescimento. Maior eficiência do tratamento de esgotos, menor produção de lodo e menor consumo de oxigênio no reator. $\mathrm{O}$ composto à base de ácido fólico iflui no metabolismo do nitrogênio, aumentando a nitrificação.

Dubé et al., 2002

Aumento da atividade e da diversidade dos microrganismos, em que foram favorecidos e se tornaram predominantes os ciliados livre-natantes e rotíferos, e ocorreu a diminuição da quantidade de ciliados pedunculados.

Aumento da quantidade de flocos e crescimento reduzido de filamentosas, sendo a

Bioprime; EPA, maioria destas associadas aos flocos. Ótima sedimentabilidade do lodo.

2003 Segundo Bioprime (2003), os resultados do monitoramento por parâmetros representativos do comportamento do reator (sólidos suspensos totais, sólidos sedimentáveis, DQO e observações microscópicas), sugerem que os ciclos de reposição da microbiota são lentos e, conseqüentemente, as perdas são substituídas lentamente, evitando o aumento de sólidos.

A partir dos resultados do presente trabalho, observou-se taxas de respiração mais elevadas em lodos ativados com a adição de ácido fólico e Dosfolat, sugerindo um estímulo da atividade metabólica dos microrgamismos, pelo aumento da respiração basal da microbiota; formação de flocos maiores e mais compactos, e com melhores características morfológicas, sendo os flocos predominantes em relação às bactérias filamentosas. Nas condições experimentais adotadas, não houve influência da adição de ácido fólico e/ou de Dosfolat na composição e diversidade dos microrganismos, na eficiência do tratamento e na produção de lodo excedente. 
Os principais parâmetros operacionais e características dos reatores das pesquisas citadas, que também estudaram a influência da adição de ácido fólico em reatores de lodos ativados, comparativamente com os dados característicos desta pesquisa, estão apresentados na Tabela 27. É necessário salientar que alguns autores não citaram informações importantes sobre alguns aspectos operacionais, de forma que nesta tabela está constando os dados que foram apresentados pelos artigos reportados neste trabalho. Apenas o autor Dubé et al. (2002) citou o tempo de detenção hidráulica utilizado, sendo de aproximadamente 12 horas.

Tabela 27 - Parâmetros operacionais e características dos reatores desta pesquisa e das pesquisas citadas que realizaram aplicação de ácido fólico em reatores de tratamento de lodos ativados

\begin{tabular}{|c|c|c|c|c|c|c|c|c|c|}
\hline \multirow{2}{*}{ AUTORES } & \multicolumn{9}{|c|}{ PARÂMETROS OPERACIONAIS } \\
\hline & Vazão & $\begin{array}{l}\text { Idade } \\
\text { do } \\
\text { lodo } \\
\text { (dias) }\end{array}$ & $\mathrm{pH}$ & $\begin{array}{l}\text { Tempe } \\
\text { ratura } \\
\text { lodo } \\
\left({ }^{\circ} \mathrm{C}\right)\end{array}$ & $\begin{array}{c}\text { Oxigênio } \\
\text { dissolvido } \\
\text { no reator } \\
(\mathrm{mg} / \mathrm{L})\end{array}$ & $\begin{array}{l}\text { Tipo de } \\
\text { efluente }\end{array}$ & $\begin{array}{l}\text { Volume do } \\
\text { reator }\end{array}$ & $\begin{array}{l}\text { Período } \\
\text { de } \\
\text { operação }\end{array}$ & $\begin{array}{c}\text { Concentração } \\
\text { de ácido fólico } \\
\text { aplicada no } \\
\text { reator } \\
(\mathrm{mg} / \mathrm{L}) \\
\end{array}$ \\
\hline $\begin{array}{l}\text { Akerboom } \\
\text { et al., } 1994\end{array}$ & $\begin{array}{c}3,37 \mathrm{~L} / \mathrm{s} \\
57 \mathrm{~L} / \mathrm{s}\end{array}$ & 1,6 & - & 16,5 & - & $\begin{array}{l}\text { Indústria de } \\
\text { papel } \\
\text { reciclado }\end{array}$ & $2.300 \mathrm{~m}^{3}$ & $\begin{array}{l}300 \\
\text { dias }\end{array}$ & - \\
\hline $\begin{array}{c}\text { Senörer, } \\
2001\end{array}$ & $\begin{array}{l}300 \mathrm{~m}^{3} / \mathrm{dia} \\
250 \mathrm{~m}^{3} / \mathrm{dia}\end{array}$ & - & - & - & - & $\begin{array}{c}\text { Esgoto } \\
\text { doméstico }\end{array}$ & - & - & $\begin{array}{l}0,2^{*} \\
0,4^{* *}\end{array}$ \\
\hline $\begin{array}{c}\text { Dubé et al., } \\
2002\end{array}$ & - & 10 & $\sim 7,0$ & $\sim 30$ & 0,5 a 2,0 & $\begin{array}{c}\text { Indústria de } \\
\text { papel }\end{array}$ & $15 \mathrm{~L}$ & $\begin{array}{l}180 \\
\text { dias }\end{array}$ & $\begin{array}{l}0,1^{*} \\
0,5^{*} \\
2,0^{* *}\end{array}$ \\
\hline $\begin{array}{c}\text { Anderl, } \\
2003\end{array}$ & - & - & - & - & 2,0 & & - & - & 0,1 \\
\hline $\begin{array}{l}\text { Atual, } \\
2005\end{array}$ & $5 \mathrm{~L} / \mathrm{dia}$ & 25 & $\begin{array}{c}6,0 \mathrm{a} \\
7,0\end{array}$ & $18-20$ & $\sim 6,0$ & $\begin{array}{c}\text { Substrato } \\
\text { sintético } \\
\text { simulando } \\
\text { esgoto } \\
\text { sanitário }\end{array}$ & $20 \mathrm{~L}$ & 60 dias & $\begin{array}{c}10^{*} \\
2,5^{* *}\end{array}$ \\
\hline
\end{tabular}

Notas: - Informação não descrita pelo autor no artigo da respectiva pesquisa

* Dosagem inicial (choque), durante os primeiros 7 dias de aplicação

** Dosagem contínua, após a dosagem inicial 


\subsubsection{Fotomicrografias mostrando o aspecto do lodo dos reatores}

Nas Figuras 41 a 46 estão apresentadas fotomicrografias registradas do lodo dos reatores controle, com adição de ácido fólico e com adição de Dosfolat, tiradas em período estabilizado do processo, e ao próximo do final do período de operação, ao $52^{\circ}$ dia de aplicação contínua das soluções (27/10/05).

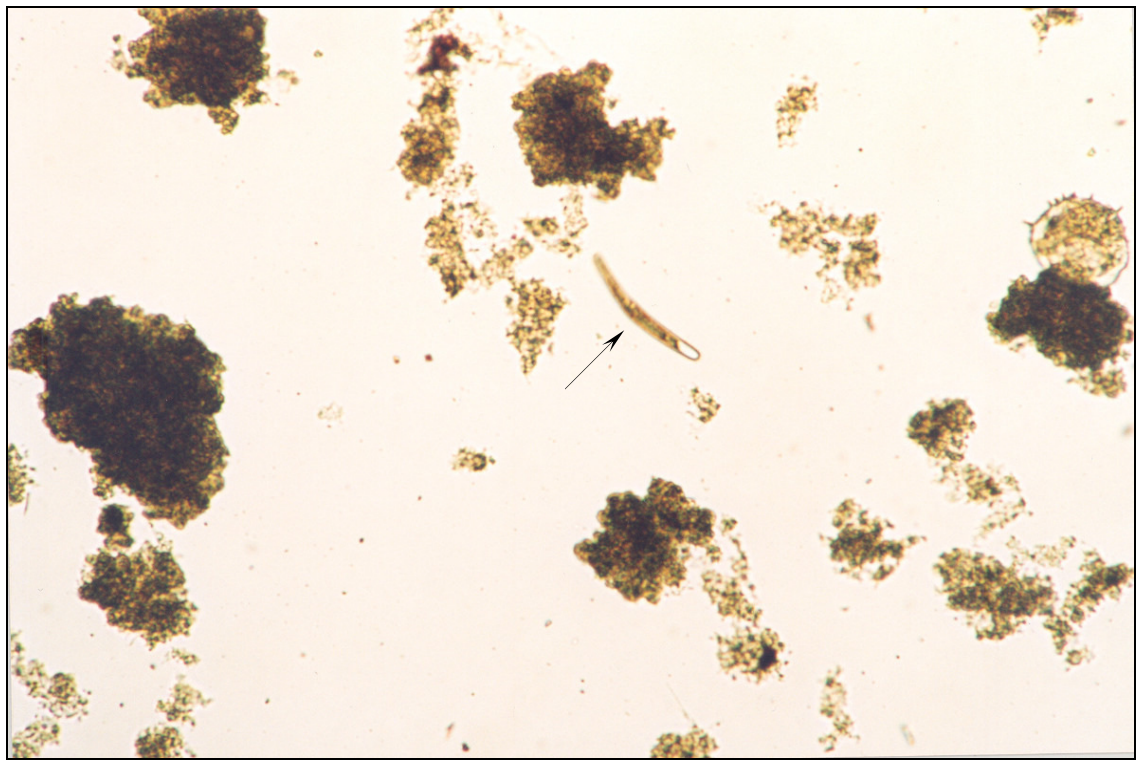

Figura 41 - Flocos do lodo do Tanque Controle, onde se observa um ciliado próximo ao centro do campo (40X)

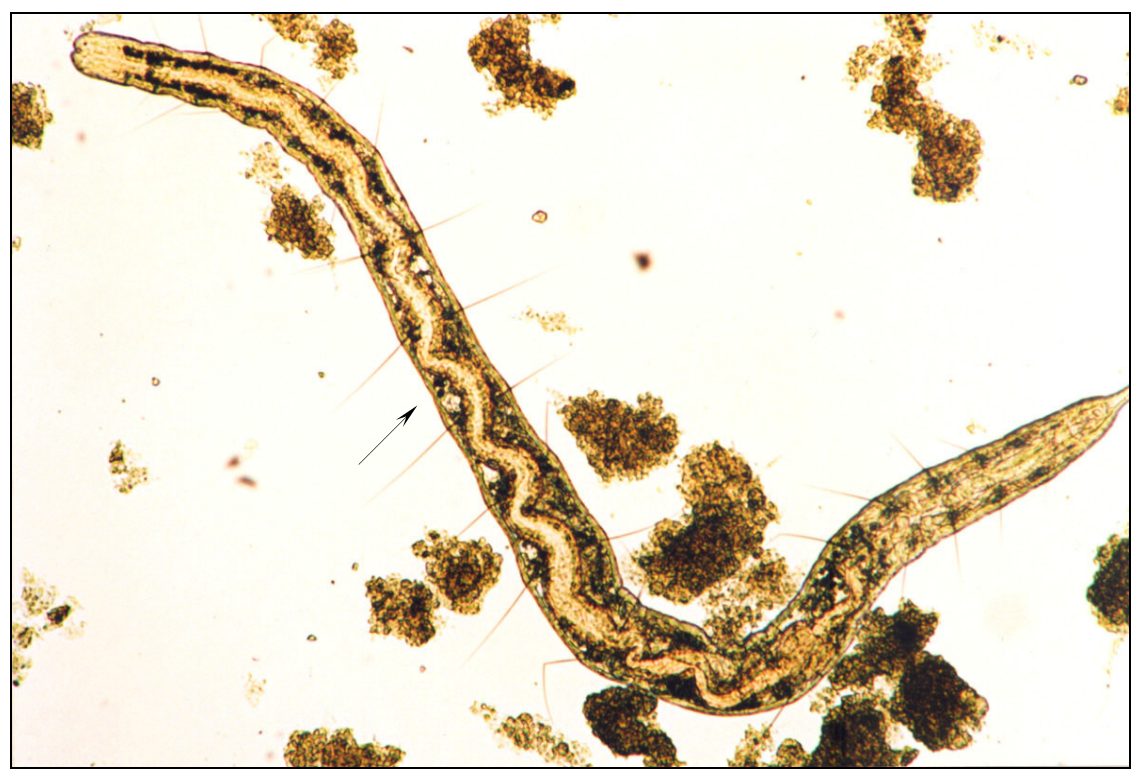

Figura 42 - Anelídeo entre os flocos do Tanque Controle (40X) 


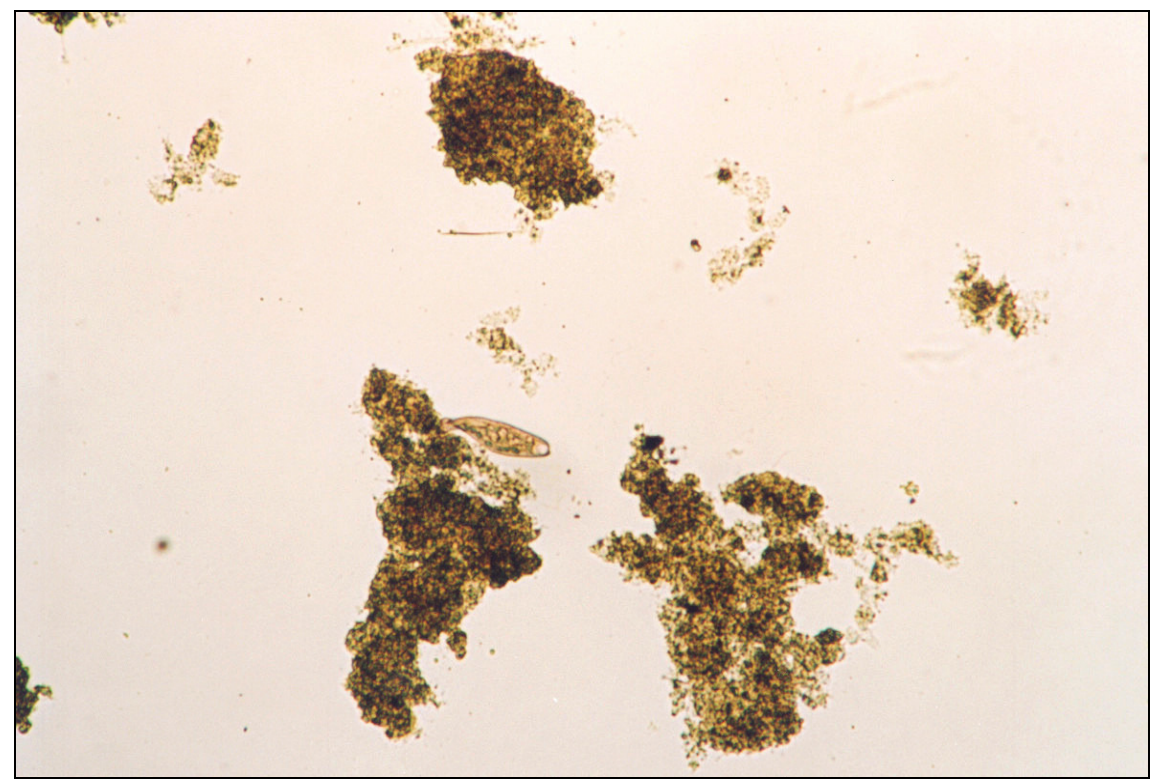

Figura 43 - Fotomicrografia mostrando flocos do Tanque com Ácido Fólico, visivelmente maiores que os do Tanque Controle (40X)

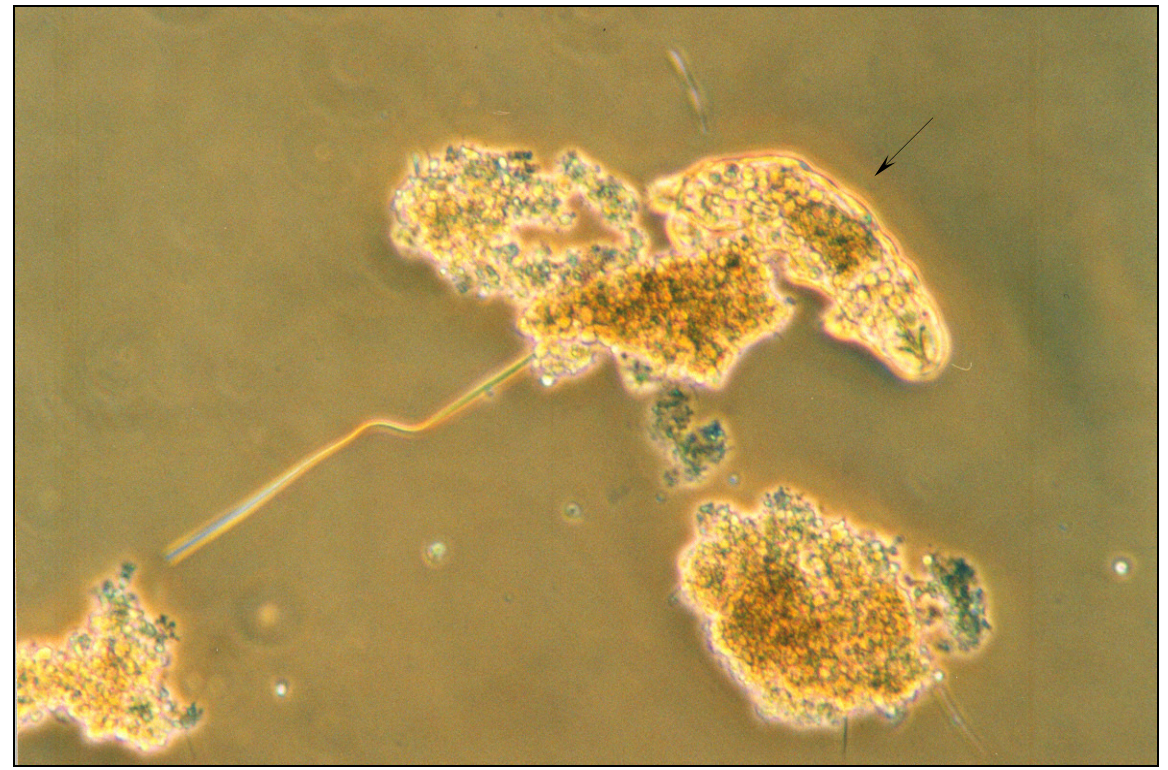

Figura 44 - Flocos do Tanque com ácido fólico, entre os quais observa-se a presença de um tardígrado (contraste de fase, 100X) 


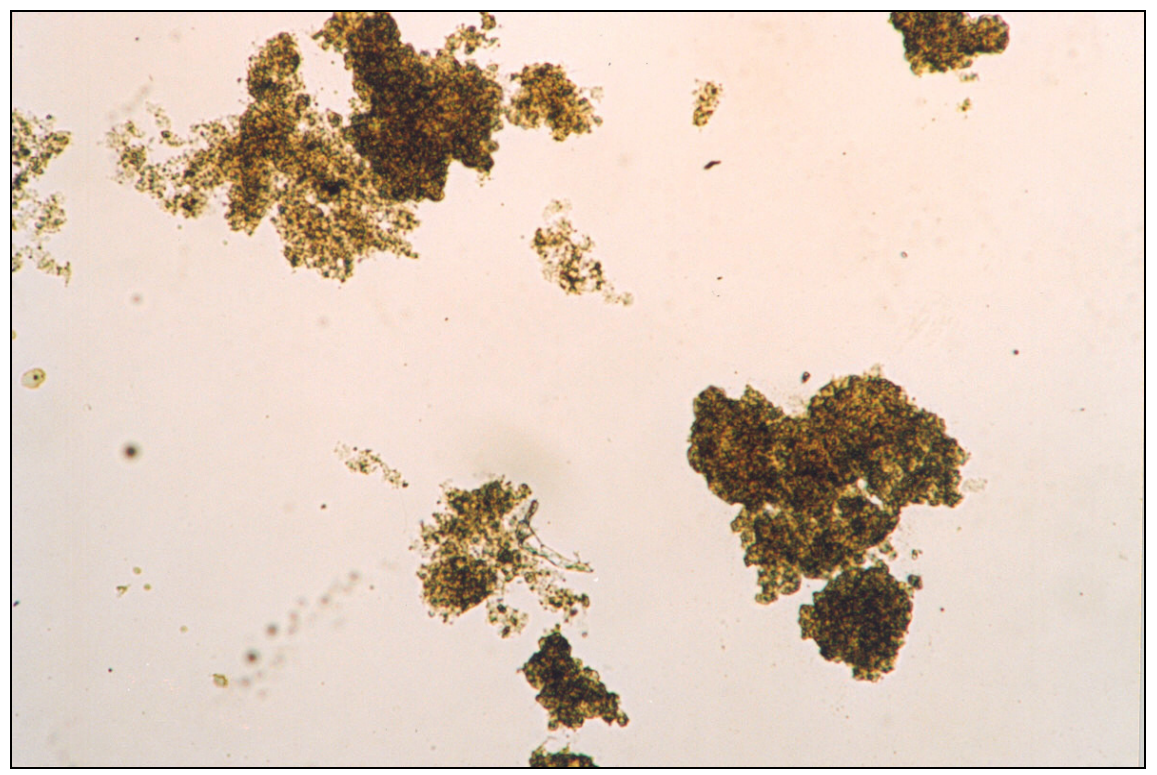

Figura 45 - Aspecto do lodo do Tanque com Dosfolat (40X)

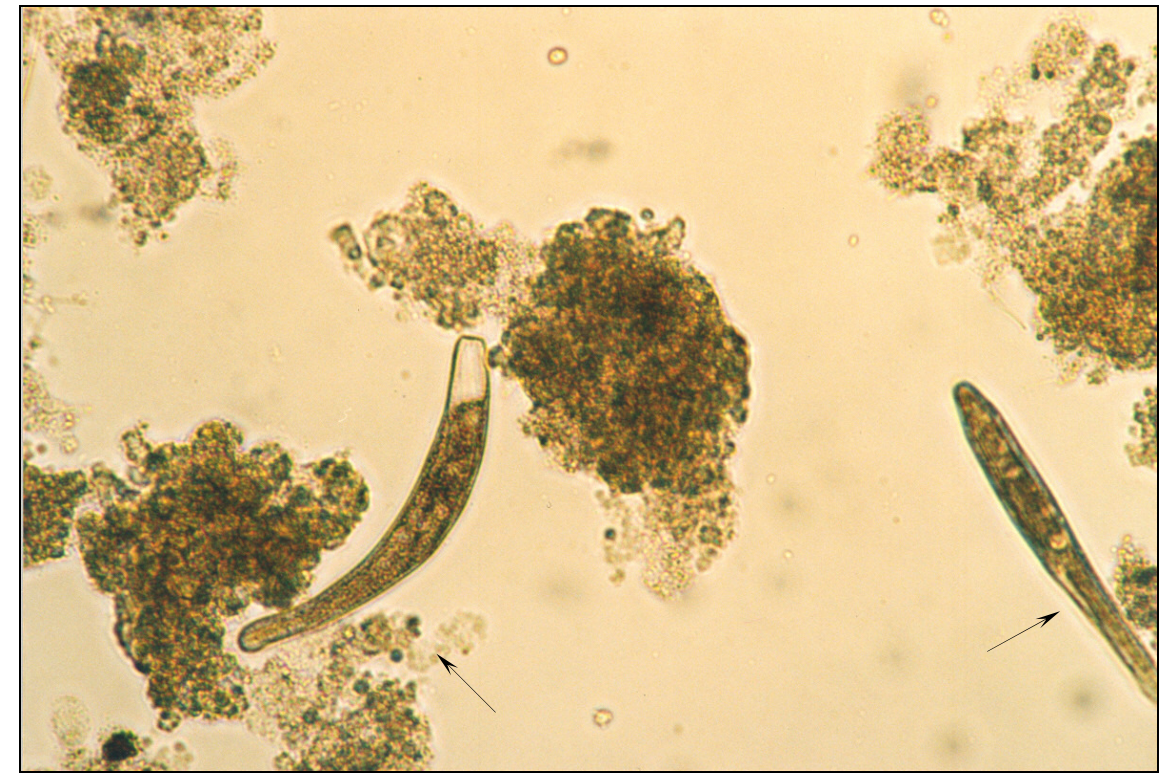

Figura 46 - Aspecto do lodo do Tanque com Dosfolat, onde se observam dois ciliados entre os flocos (100X) 


\section{CONCLUSÕES}

A avaliação da atividade de microrganismos através da quantificação de oxigênio consumido permite determinar a velocidade de degradação de substâncias orgânicas do esgoto, decorrentes dos processos metabólicos. Desta forma, sendo a taxa de consumo de oxigênio função do crescimento da comunidade microbiana e o conseqüente aumento da taxa de degradação, os bioensaios de respirometria revelaram influência dos efeitos da aplicação do ácido fólico e do composto Dosfolat sobre a comunidade do lodo, sugerindo um estímulo da respiração basal da microbiota.

O consumo de oxigênio nos frascos com adição da maior concentração de ácido fólico testada - 4,0 mg/L, destacou-se com o consumo de até $78 \%$ de oxigênio, enquanto que nos frascos controles o consumo médio foi de $50 \%$. O composto Dosfolat, empregado com a concentração $2,5 \mathrm{mg} / \mathrm{L}$, também favoreceu a atividade da microbiota de lodos estudados, ocorrendo influência positiva no incremento do consumo de oxigênio, sendo observado o consumo de $100 \%$ do oxigênio presente após 24 horas de incubação dos sistemas de respirometria. Paralelamente, no mesmo bioensaio respirométrico em que o Dosfolat foi testado, o ácido fólico grau analítico (com concentração $2,5 \mathrm{mg} / \mathrm{L}$ ) foi utilizado, no qual ocorreu consumo médio de oxigênio de $67 \%$ ao final do período de incubação de cinco dias, comparados a $54 \%$ nos frascos controle.

Nos sistemas de lodos ativados em batelada, verificou-se que os resultados dos efluentes dos reatores com adição de ácido fólico e do composto Dosfolat são muito próximos aos do reator controle. Portanto, nas condições experimentais adotadas é possível afirmar que o ácido 
fólico e o composto Dosfolat não exerceram influência na eficiência do tratamento e na produção de lodo excedente.

Em relação aos aspectos da microbiologia dos sistemas, não houveram diferenças na composição e diversidade da microfauna dos três reatores durante o período operacional. Nos reatores que receberam adição de ácido fólico e Dosfolat os flocos apresentaram tamanhos superiores, e melhores características morfológicas em relação aos do lodo do reator controle, quanto ao tamanho, forma e estrutura. Porém, o crescimento de bactérias filamentosas ocorreu de forma semelhante nos três reatores estudados, com resultados muito próximos. Embora a adição destas soluções mostrou tendência de crescimento maior de bactérias formadoras de flocos, estas não influenciaram a dinâmica de crescimento das bactérias filamentosas.

Portanto, os aspectos que se destacaram foram:

- a influência da presença de ácido fólico e de Dosfolat em sistemas de lodos ativados nas taxas de respiração, sendo mais elevadas após a adição de ambas as soluções, indicando uma tendência de estímulo da atividade metabólica como resposta ao incremento de ácido fólico.

- alterações da qualidade e do tamanho dos flocos, sendo superiores no lodo com adição de ácido fólico e de Dosfolat, cuja tendência sugere que a utilização de ambas as soluções favorece o crescimento das bactérias dos flocos e a formação destes, em detrimento às bactérias livres. 


\section{RECOMENDAÇÕES}

- Aplicar a metodologia utilizada em período mais extenso de operação;

- Operar os sistemas com idade do lodo mais baixa;

- Testar outras concentrações de ácido fólico e de Dosfolat;

- Aplicação de técnicas moleculares para análise qualitativa e quantitativa da microbiota, para uma avaliação mais apurada do crescimento e diversidade dos microrganismos na presença de ácido fólico. 


\section{REFERÊNCIAS DE LITERATURA}

AISSE, M.M. Sedimentação do lodo secundário obtido no processo de lodos ativados. Dissertação (Mestrado) - Escola de Engenharia de São Carlos, Universidade de São Paulo, São Paulo, 1985. 205p.

ALÉM SOBRINHO, P. Estudo dos fatores que influem no desempenho do processo de lodos ativados - determinação dos parâmetros de projeto para esgotos predominantemente domésticos. In: IV Curso Internacional sobre Controle de Poluição das Águas. CETESB, 1998.

AKERBOOM, R.K.; LUTZ, P.; BERGER, H.F. Folic acid reduces the use of secondary treatment additives in treating wastewater from paper recycling. In: International Environmental Conference - TAPPI Proceedings. 1994

AKHTAR, M.J.; KHAN, M.A.; AHMAD, I. Photodegradation of folic acid in aqueous solution. Journal of Pharmaceutical and Biomedical Analysis, 25 (1), p. 269-275, 1999.

ANDERL, A. A vitamin for biological sewage treatment plants. (Publicado em Biotecnologie. № 5, 1987). Disponível em: <http://www.dosfolat.de/literature/DOSFOLAT_Anderl_e.pdf>. Acesso em: 07 jun. 2003.

American Public Health Association; American Water Works Association and Water Pollution Control Facilities. Standard methods for examination of water and wastewater American Public Health Association, American Water Works Association, Water Environment Federation. [Ed] Lenore S. Clesceri, Arnold E. Greenberg, Andrew D. Eaton. 20th ed. Washington, D.C.: American Public Health Association, 1998.

BAYLY, A.M.; BERGLEZ, J.M.; PATEL, O.; CASTELLI, L.A., HANKINS, E.G.; COLOE, P.; SIBLEY, C.H.; MACREADIE, I.G. Folic acid utilization related to sulfa drug resistance in Saccharomyces cerevisiae. FEMS Microbiology Letters, 204, p. 387-390, 2001. 
BARNES, R.D.; RUPPERT, E.E. Zoologia dos Invertebrados. 6ed. São Paulo: Roca, 1996. $1029 \mathrm{p}$.

BARNES, R.S.K.; CALOW, P.; OLIVE, P.J.W. The Invertebrates: a new synthesis. 6ed. Oxford: Blakwell Scientific Publicatins, 1988. 582p.

BERK, S.G.; GUNDERSON, J.H. Wastewater organisms: a color atlas. / Sharon G. Berk and John H. Gunderson. Florida: CRC Press, 1993. 25p.

BIOPRIME. Environmental Technologies from Europe. Apresenta resultados obtidos com a aplicação de Dosfolat em lodos ativados. Disponível em: <http://www.bioprime.com>. Acesso em: 07 jun. 2003.

BITTON, G. Wastewater microbiology. 2 nd. Canada: Wiley-Liss, 1999. 578p.

BLACK, J.G. Microbiology: principles and applications. 3nd ed. New York: Prentice Hall, 1996. 790p.

BLOUNT, B.C.; MACK, M.M.; WEHR, C.M. Folate deficiency causes uracil misincorporation into human DNA and chromosome breakage. Proc. Natl. Acad. Sci. USA, v.94, p. 3290-3295, 1997.

BRANCO, S.M. Hidrobiologia aplicada à engenharia sanitária. 3ed. São Paulo : Cetesb / Ascetesb, 1986. $616 \mathrm{p}$

BONECHI, C.; DONATI, A., LAMPARIELLO, R.; MARTINI, S.; PUCCHI, M.P.; RICCI, M.; ROSSI, C. Solution structure of folic acid - Molecular mechanics and NMR investigation. Spectrochimica Acta - Part A, 60, p. 1411-1419, 2004.

CAMPOS, J.R. Alternativas para Tratamento de Esgotos - Pré-tratamento de Águas para Abastecimento. Publicação nº 09. Americana: Consórcio Intermunicipal das Bacias dos Rios Piracicaba e Capivari, 1994. 
CARMONA, F.J.; VÁZQUEZ, F.J.; MARTÍN, A.; CHICA, A. (2004). "Diseño y construcción de un respirómetro", in Anais da XXV Jornada de Automática, Ciudad Real (Espanha), 8 - 10 Set., pp. 73 - 80.

CHAMPE, P.C. Bioquímica Ilustrada. 2ed. Porto Alegre: Artes Médicas Sul, 1996. 446p.

CHAVES, A.C.S.D.; HUGENHOLTZ, J.; LERAYER, A.L.S. Engenharia metabólica do ácido fólico. Biotecnologia, Ciência \& Desenvolvimento. Set-Out/2002. №28. Disponível em: <http://www.biotecnologia.com.br/bio28/28 acid.pdf $>$. Acesso em: 17 jun. 2003.

CONAMA. CONSELHO NACIONAL DE MEIO AMBIENTE, Ministério do Meio Ambiente. Resolução CONAMA No 357/2005, de 18/03/2005. Dispõe sobre a classificação dos corpos de água e diretrizes ambientais para o seu enquadramento, bem como estabelece as condições e padrões de lançamento de efluentes, e dá outras providências. Disponível em: <http://www.mma.gov.br/port/conama/res/res86/res2086.html>. Acesso em 17/11/2005.

CONCHON, E.A. Programa de redução da geração de biossólidos. Neotex Soluções Ambientais. Disponível em: http://www.dosfolat.de/reports/NEOTEX2003br.ppt. Produzido em 1998. Acesso em: 07 jun. 2003.

CRITES, R; TCHOBAnOglous,G. Tratamiento de Aguas Residuales em Pequeñas Poblaciones. Bogotá: McGraw-Hill, 2000. 776p.

CRITTENDEN, R.G.; MARTINEZ, N.R.; PLAYNE, M.J. International Journal of Food Microbiol., 80 (217), 2002.

CSUROS, M. Microbiological examination of water and wastewater. London: Lewis Publishers, 1999. 324p. 
CURDS, C.R.; HAWKES, H.A. Ecological aspects of used-water treatment. London: Academic Press, 1983.

DOOHAN, M. Rotifera In: CURDS, C.R.; HAWKES, H.A. Ecological aspects of used water tratement. London, Academic Press, 1975. p.289-304.

DAMATO, M.; SOBRINHO, P.A.; MORITA, D.M. Emprego de uma espécie de rotífero, Brachionus calyciflorus, na determinação da toxicidade aguda no afluente e efluente de sistemas de lodos ativados em duas refinarias de petróleo. In: $20^{\circ}$ Congresso Brasileiro de Engenharia Sanitária e Ambiental, 1999, Rio de Janeiro. (Anais). Rio de Janeiro: Associação Brasileira de Engenharia Sanitária e Ambiental, 1999. p.200-207.

DONNELLY, J.G. Folic acid. In: Critical Reviews in Clinical Laboratory Sciences. 38 (3): 183-223, 2001.

DOSFOLAT. Apresenta descrição do produto Dosfolat, formas de aplicação e segurança, informações sobre venda e suporte técnico. Disponível em: <http://www.dosfolat.de>. Acesso em: 28 maio 2003.

DOSFOLAT. Dosfolat $®$ XS reduces waste sludge in biological sewage treatment plants. Disponível em: <http://www.dosfolat.de/product/prod_fig2.html>. Acesso em: 21 junho 2004.

DOSFOLAT. Effect of toxic substances in wastewater halted or reduced bu Dosfolat. Alphachemie GmbH, Hamburg. 1988.

DROGUETTI, D.C.; PENTEAdO, M.V.C. Ácido fólico. In: PENTEADO, M.V.C. (Org.). Vitaminas: aspectos nutricionais, bioquímicos, clínicos e analíticos. Barueri: Manole, 2003. Cap. 13, p.487-524.

DUBÉ, E.; GAGNON, D.; LAVALlÉE, H.C.; ROBERT, S. Applications of folic acid in secondary wastewater treatment. In: Environmental Conference. 2002. TAPPI 
ECKENFELDER, W.W. Activated sludge process design and control: theory and practice. Lancaster: Technomic Pub. Co., 1992.

EIKELBOOM, D.H.; BUIJSEN, H.J.J. Microscopic sludge investigation manual. Delft: TNO Research Institute for Environmental Hygienne. 1981. 71p.

EIKELBOOM, D.H. Process control of activated sludge plants by microscopic investigation. London: IWA, 2000. 156 p.

EPA. Ecological Effects Test Guidelines. Modified Activated Sludge, Respiration Inhibition Test for Sparingly Soluble Chemicals. United States: 1996.

EPA. New England. Technology type of wastewater treatment, technology Description, Application, Environmental Benefits, Performance and Limitations. Disponível em: $<$ http://www.epa.gov/NE/assistance/ceit iti/tech cos/bio.html $>$. Acesso em: 28 maio 2003.

FERNANDES, J.G.S.; HAANDEL, A.V.; CAVALCANTI, P.F.F.; COURA, L.R. (2001). "Utilização da respirometria no controle operacional de sistemas aeróbios de tratamento de águas residuárias - a experiência da Cetrel”. Revista Engenharia Sanitária e Ambiental - ABES, 6, 3, Outubro/Dezembro, pp.131-137.

FIGUEIREDO, M.G. Microbiologia de lodos ativados. In: I Curso Internacional sobre Controle de Poluição das Águas. CETESB, 1995.

GARRET, R.H.; GRISHAM, C.H. Biochemistry. Fort Worth (Texas): Saunders College Publishing, 1995.

GERNAEY, A.K.; PETERSEN, B.; OTTOY, J.P.; VANROLLEGHEM, P.(2001). “Activated sludge monitoring with combined respirometric-titrimetric measurements". Water Reserarch, 35, 5, pp.1280 - 1294. 
GREEN, J.M. BALLOU, D.P.; MATTHEWS, R.G. Examination of the role of methylenetetrahydrofolate reductase in incorporation of methyltetrahidrofolate into cellular metabolism. Faseb J. 1988. 2(1):42-7.

GRIEBE, T.; SCHAULE, G.; WUERTZ, S. (1997). “Determination of microbial respiratory and redox activity in activated sludge". Journal of Industrial Microbiology \& Biotechnology, 19, Maio, pp.118 - 122.

GUILLAND, J.C.; LEQUEU, B. As Vitaminas. Santos: São Paulo, 1995. 357 p.

HORAN, N.J. Biological wastewater treatment systems: theory and operation. New York: Wiley, 1990. 310p.

JENKINS, D.; RICHARD, M.G.; DAIGGER, G.T. Manual on the causes and control of activated sludge bulking and foaming. 2nd ed. London: Lewis Publishers, 1993. 193p.

JENKINS, D.; RICHARD, M.G.; DAIGGER, G.T. Manual on the causes and control of activated sludge bulking, foaming and other solids separation problems. 3rd ed. London: Lewis Publishers, 2004. 190p.

JIWANI, A.; GRAHAM, N.J.D.; DAY, M.C. Activated sludge process control via particle monitoring. Water Science and Technology, 36 (4), p.269-277. 1997.

JOHN, J. M; NEWMAN, R.A. Chromatographic studies of folic acid and related compounds. In: Leenheer, A.P. (Org.). Modern Chromatographic Analysis of the Vitamins. New York: Decker, 1985. Cap. 6, p.303-335.

LEHNINGER, A.L.; NELSON, D.L.; COX, M.M. Principles of Biochemistry. 3rd ed. New York: Wohth, 2000. 1152p. 
LEMMER, H.; LIND, G.; METZNER, G.; NITSCHKE, L.; SCHADE, M. Vitamin addition in biological wastewater treatment. In: II International Conference on Microorganisms in activated sludge and biofilm process. California / USA: 1997.

LESTER, J.N.; BIRKETT, J.W. Microbiology and chemistry for environmental scientists and engineers. 2nd ed. London: E \& FN Spon, 1999. 386p.

LINDENABAUM, J.; ALLEN, R.H. Clinical spectrum and diagnosis of folate deficiency. [Ed] Bailey L.B. In: Folate in health and disease, Marcel Dekker: New York, 1995.

MADONI, P. A sludge biotic index (SBI) for the evaluation of the biological performance of activated sludge plants based on the microfauna analysis. Water Research, 28 (1): p. 67$75,1994$.

MARCONI, R.G. Definição do Ciclo Operacional de um Reator Seqüencial em Batelada Aeróbio (SBR) para Tratamento de Esgoto Sanitário. Dissertação (Mestrado) Escola de Engenharia de São Carlos, Universidade de São Paulo, São Carlos: 2001. $147 \mathrm{p}$.

MENDONÇA, L.C. Microbiologia e Cinética de Sistemas de Lodos Ativados como Póstratamento de Efluente de Reator Anaeróbio de Leito Expandido. Tese (Doutorado) - Escola de Engenharia de São Carlos, Universidade de São Paulo, São Carlos: 2002. $219 \mathrm{p}$.

METCALF \& EDDY, INC. Wastewater Engineering: Treatment, Disposal, Reuse. [Ed] George Tchobanoglous. $3^{\mathrm{a}}$ ed. Nova York: McGraw-Hill, 1991. 1334p.

MOHR, H. Folic acid - a micronutritive and promoter of growth for bacteria and fungus. Biotechnologie. $1987 . \quad$ Issue $10 . \quad$ Disponível em:

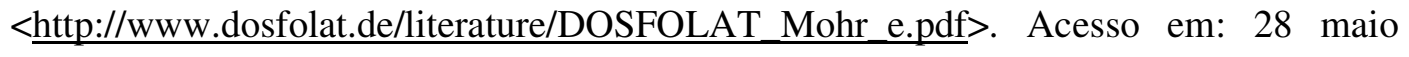
2003. 
MURRAY, P.R.; ROSENTHAL, K.S.; KOBAYASHI, G.S.; PFALLER, M.A. Microbiologia Médica. Rio de Janeiro: Guanabara Koogan, 1998. 604p.

NICOLAU, A.; DIAS, N.; MOTA, M.; LIMA, N. Trends in the use of protozoa in the assessment of wastewater treatment, Res. Microbiol., 152, p. 621-630. 2001.

O'NEIL, M.J. The merck index: an encyclopedia of chemicals, drugs, and biologicals. 13th ed. / [Ed] Maryadele J. O'Neil et al. Whitehouse Station, NJ: Merck Research Laboratories, 2001.

OSTRANDER, S.J. A non-conventional solution to an old problem. Operations Forum. Vol.9. No.1. 1992. Disponível em: <http://www.dosfolat.de/literature/ostrander/ostrander.html>. Acesso em: 28 maio 2003.

PELCZAR JR, J.M.; CHAN, E.C.S.; KRIEG, N.R. Microbiologia: conceitos e aplicações. 2ed. São Paulo: Makron Books, 1996. 524p. v.1.

PEREZ, M.F. Estudo sobre o emprego da alimentação alternada para o controle do intumescimento do lodo em sistemas de lodos ativados tratando esgotos sanitários predominantemente domésticos. Dissertação (Mestrado) - Escola Politécnica da Universidade de São Paulo. São Paulo, 1995. 378p.

SABESP. São Paulo: Companhia de Saneamento Básico do Estado de São Paulo, 2004.

Disponível em: <http://www.sabesp.com.br/tratamento_metropolitano _sistemaABC.htm>. Acesso em: 27 abril 2004.

SACKHEIM, G.I.; LEHMAN, D.D. Química e Bioquímica para Ciências Biomédicas. Barueri: Manole, 2001. 644p.

SENÖRER, E. Determination of effect of folic acid in biological treatment efficiency. 2001. Disponível em: <http://www.dosfolat.de/literature/dosfolatxs.pdf>. Acesso em: 7 junho 2003. 
VAN HAANDEL, A.; MARAIS, G. O comportamento do sistema de lodo ativado.: Campina Grande: Epgraf, 1999. 488p.

VAZOLLER, R.F. Microbiologia de lodos ativados. São Paulo: CETESB, 1989. 23p. (Série Manuais).

VIEIRA, E.C.; GAZZINELLI, G.; MARES-GUIA, M. Química Fisiológica. Rio de Janeiro: Atheneu, 1979.

VILLAS BÔAS, D.M. Caracterização de Águas Residuárias - Microbiologia. São Paulo: Escola Politécnica - USP, 1996. 42 p. Apostila integrante do material didático utilizado na discipina “Técnicas Analíticas de Caracterização de Amostras de Água e Esgotos”.

VILLAS BÔAS, D.M.F. Estudo microbiológico de sistemas de lodos ativados com ênfase nas bactérias degradadoras de fenol. Tese (Doutorado) - Escola Politécnica da Universidade de São Paulo. São Paulo, 1999. 161 p.

VOET, D.; VOET, J.G.; PRATT, C.W. Fundamentos de Bioquímica. Porto Alegre: Artmed, 2002. 931p.

VON SPERLING, M. Princípios básicos do tratamento de esgotos. Belo Horizonte: Departamento de Engenharia Sanitária e Ambiental / Universidade Federal de Minas Gerais, 1996. 211 p. (Princípios do tratamento biológico de águas residuárias, v.2).

VON SPERLING, M. Lodos ativados. Belo Horizonte: Departamento de Engenharia Sanitária e Ambiental / Universidade Federal de Minas Gerais, 1997. 416 p. (Princípios do tratamento biológico de águas residuárias, v.4).

WAGNER, C. Biochemical role of folate in cellular metabolism. Bailey L.B. eds. Folate in health and disease. Marcel Dekker: New York, 1995. p.23-42. 
WEBB, J.E. WALLWORK, J.A.; ELGOOD, J.H. Guide do Invertebrate Animals. 2ed. London: Macmillan, 1985. 305p.

WEI, Y.; HOUTEN, R.T.V.; BORGER, A.R.; EIKELBOOM, D.H.; YAOBO, F. Minimization of excess sludge production for biological wastewater treatment. Water Research, 37, p.4453-4467. 2003. 
9. ANEXO 


\section{ANEXO 1 - TABELAS COM RESULTADOS DOS BIOENSAIOS DE RESPIROMETRIA}

Tabela 28 - Bioensaio de respirometria 1, apresentando os resultados de consumo de oxigênio e de DBO em frascos com adição de 1,0 e 2,0 mg/L de ácido fólico, comparados a frascos controle

\begin{tabular}{|c|c|c|c|c|c|c|c|c|c|}
\hline $\begin{array}{c}\text { DATA } \\
\text { INCUBAÇÃO }\end{array}$ & $\begin{array}{c}\text { DATA } \\
\text { LEITURA }\end{array}$ & $\begin{array}{l}\text { CONDIÇÃO } \\
\text { DOS } \\
\text { FRASCOS }\end{array}$ & $\begin{array}{l}\text { VOLUME } \\
\text { AMOSTRA }\end{array}$ & $\begin{array}{l}\text { CONSUMO } \\
\text { OXIGÊNIO } \\
(\%)\end{array}$ & $\begin{array}{c}\text { CONSUMO } \\
\text { MÉDIO DE O2 } \\
(\%)- \\
\text { (duplicatas) }\end{array}$ & $\begin{array}{c}\text { DESVIO } \\
\text { PADRÃO }\end{array}$ & DBO & $\begin{array}{l}\text { DBO média } \\
\text { (das } \\
\text { duplicatas) }\end{array}$ & DBO média \\
\hline \multirow{10}{*}{$28 / 11 / 03$} & \multirow{10}{*}{$03 / 11 / 03$} & \multirow{10}{*}{ CONTROLE } & \multirow{2}{*}{0,1} & 27 & \multirow{2}{*}{29} & \multirow{2}{*}{2} & 5470 & \multirow{2}{*}{5718} & \multirow{10}{*}{2249} \\
\hline & & & & 31 & & & 5966 & & \\
\hline & & & \multirow{2}{*}{0,5} & 53 & \multirow{2}{*}{53} & \multirow{2}{*}{0} & 2045 & \multirow{2}{*}{2127} & \\
\hline & & & & 53 & & & 2209 & & \\
\hline & & & 10 & 66 & \multirow{2}{*}{51} & \multirow{2}{*}{15} & 1376 & \multirow{2}{*}{1056} & \\
\hline & & & 1,0 & 35 & & & 735 & & \\
\hline & & & \multirow{2}{*}{$1,5^{\star}$} & 97 & \multirow{2}{*}{98} & \multirow{2}{*}{0} & 1300 & \multirow{2}{*}{1338} & \\
\hline & & & & 98 & & & 1375 & & \\
\hline & & & \multirow{2}{*}{$2,0^{*}$} & 99 & \multirow{2}{*}{98} & \multirow{2}{*}{1} & 1022 & \multirow{2}{*}{1005} & \\
\hline & & & & 98 & & & 988 & & \\
\hline \multirow{10}{*}{ 28/11/03 } & \multirow{10}{*}{$03 / 11 / 04$} & \multirow{10}{*}{$\begin{array}{l}\text { Com } 1,0 \\
\mathrm{mg} / \mathrm{L} \text { de } \\
\text { ÁCIDO } \\
\text { FÓLICO }\end{array}$} & \multirow{2}{*}{$0,1^{*}$} & 34 & \multirow{2}{*}{30} & \multirow{2}{*}{4} & 6797 & 6112 & \\
\hline & & & & 27 & & & 5428 & שוזם & \\
\hline & & & & 50 & & & 2036 & & \\
\hline & & & 0,0 & 52 & 51 & 1 & 2098 & 2061 & \\
\hline & & & 10 & 65 & 66 & 1 & 1299 & 1287 & 2532 \\
\hline & & & & 67 & o & 1 & 1275 & I & \\
\hline & & & & 99 & & & 1302 & & \\
\hline & & & & 98 & 50 & 1 & 1309 & (1500, & \\
\hline & & & $\Omega^{*}$ & 99 & קח & 0 & 1017 & & \\
\hline & & & & 99 & & & 915 & & \\
\hline & & & & 30 & & 0 & 6513 & 0111 & \\
\hline & & & 0,1 & 31 & 30 & v & 6309 & ודודם & \\
\hline & & & & 52 & $5 ?$ & 1 & 2035 & مคA & \\
\hline & & & 0,0 & 53 & 52 & 1 & 2102 & 2009 & \\
\hline & & Com 2 mg/L & & 63 & & & 1196 & & 0 \\
\hline 28/11/05 & $03 / 11 / 06$ & $\begin{array}{l}\text { de ACIDO } \\
\text { FÓLICO }\end{array}$ & 1,0 & 69 & 66 & 3 & 1352 & $12 / 4$ & 3251 \\
\hline & & & & 99 & & & 1277 & & \\
\hline & & & $1,5^{*}$ & 99 & 99 & 0 & 1234 & 1256 & \\
\hline & & & ? $\overbrace{}^{*}$ & 99 & & 0 & 1027 & & \\
\hline & & & & 100 & & & 977 & & \\
\hline
\end{tabular}

Nota: * Resultados obtidos nos frascos com estes volumes de lodo não foram considerados, por não se enquadrarem nos critérios de aceitação da análise de DBO, que segundo a referência Standard Methods (APHA et al., 1998), são: consumo de oxigênio durante os cinco dias de incubação maior que $2 \mathrm{mgO}_{2} / \mathrm{L}$ e concentração final de oxigênio dissolvido maior que $1 \mathrm{mgO}_{2} / \mathrm{L}$. 
Tabela 29 - Bioensaio de respirometria 2, apresentando os resultados do consumo de oxigênio e DBO obtidos em frascos com adição de 2,5 e 4,0 mg/L de ácido fólico, comparados a frascos controle

\begin{tabular}{|c|c|c|c|c|c|c|c|c|c|}
\hline $\begin{array}{c}\text { DATA } \\
\text { INCUBAÇÃO }\end{array}$ & $\begin{array}{c}\text { DATA } \\
\text { LEITURA }\end{array}$ & $\begin{array}{l}\text { CONDIÇÃO } \\
\text { DOS } \\
\text { FRASCOS }\end{array}$ & $\begin{array}{l}\text { VOLUME } \\
\text { AMOSTRA }\end{array}$ & $\begin{array}{l}\text { CONSUMO } \\
\text { OXIGÊNIO } \\
(\%)\end{array}$ & $\begin{array}{c}\text { CONSUMO } \\
\text { MÉDIO DE O2 } \\
(\%)- \\
\text { (duplicatas) }\end{array}$ & $\begin{array}{c}\text { DESVIO } \\
\text { PADRÃO }\end{array}$ & DBO & $\begin{array}{l}\text { DBO média } \\
\text { (das } \\
\text { duplicatas) }\end{array}$ & DBO média \\
\hline \multirow{10}{*}{$16 / 01 / 04$} & \multirow{10}{*}{$21 / 01 / 04$} & \multirow{10}{*}{ CONTROLE } & \multirow{2}{*}{0,1} & 10 & \multirow{2}{*}{13} & \multirow{2}{*}{3} & 2148 & \multirow{2}{*}{2498} & \multirow{10}{*}{1754} \\
\hline & & & & 15 & & & 2848 & & \\
\hline & & & \multirow{2}{*}{0,3} & 31 & \multirow[b]{2}{*}{31} & \multirow[b]{2}{*}{1} & 2096 & \multirow{2}{*}{2109} & \\
\hline & & & & 30 & & & 2121 & & \\
\hline & & & 05 & 13 & 26 & 13 & & 1119 & \\
\hline & & & & 39 & & & 1665 & & \\
\hline & & & \multirow{2}{*}{1,0} & 62 & \multirow{2}{*}{61} & \multirow{2}{*}{2} & 1284 & \multirow{2}{*}{1291} & \\
\hline & & & & 59 & & & 1298 & & \\
\hline & & & \multirow{2}{*}{$1,5^{\star}$} & 93 & \multirow{2}{*}{96} & \multirow{2}{*}{3} & 1342 & \multirow{2}{*}{1355} & \\
\hline & & & & 99 & & & 1367 & & \\
\hline \multirow{10}{*}{$16 / 01 / 04$} & \multirow{10}{*}{$21 / 01 / 04$} & \multirow{10}{*}{$\begin{array}{c}\text { Com 2,5 mg/L } \\
\text { de ÁCIDO } \\
\text { FÓLICO }\end{array}$} & 01 & 16 & 17 & 1 & 3226 & 2350 & \multirow{10}{*}{2310,5} \\
\hline & & & T & 17 & r & 1 & 3491 & (2000 & \\
\hline & & & & 36 & & & 2527 & & \\
\hline & & & 0,3 & 36 & 30 & 0 & & 2518,5 & \\
\hline & & & 05 & 45 & 47 & 2 & 1822 & 18675 & \\
\hline & & & & 49 & & & 1913 & & \\
\hline & & & 1 & 71 & 70 & 1 & 1494 & 11075 & \\
\hline & & & 1 & 73 & 10 & 1 & 1501 & שי & \\
\hline & & & $15 *$ & 100 & 100 & 0 & 1384 & 1216 & \\
\hline & & & 1,0 & 100 & 100 & 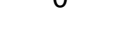 & 1248 & שת & \\
\hline \multirow{10}{*}{$16 / 01 / 04$} & \multirow{10}{*}{$21 / 01 / 04$} & \multirow{10}{*}{$\begin{array}{c}\text { Com 4,0 mg/L } \\
\text { de ÁCIDO } \\
\text { FÓLICO }\end{array}$} & & 21 & & & 4577 & & \multirow{10}{*}{2436} \\
\hline & & & 0,1 & 16 & 19 & 3 & 3317 & 3941 & \\
\hline & & & & 32 & & & 2176 & & \\
\hline & & & 0,3 & 38 & 35 & 3 & 2542 & 2359 & \\
\hline & & & & 45 & & & 1731 & & \\
\hline & & & 0,0 & 52 & 49 & 4 & 2092 & ט, ודותו & \\
\hline & & & 1 & 74 & 70 & 1 & 1485 & 1527 & \\
\hline & & & 1 & 81 & 10 & 4 & 1568 & tuct & \\
\hline & & & \multirow{2}{*}{$1,5^{*}$} & 100 & 100 & 0 & 1399 & & \\
\hline & & & & 100 & 100 & $v$ & 1328 & (1000, & \\
\hline
\end{tabular}

Nota: * Resultados obtidos nos frascos com estes volumes de lodo não foram considerados, por não se enquadrarem nos critérios de aceitação da análise de DBO, que segundo a referência Standard Methods (APHA et al, 1998), são: consumo de oxigênio durante os cinco dias de incubação maior que $2 \mathrm{mgO}_{2} / \mathrm{L}$ e concentração final de oxigênio dissolvido maior que $1 \mathrm{mgO}_{2} / \mathrm{L}$. 
Tabela 30 - Bioensaio de respirometria 3, apresentando os resultados do consumo de oxigênio e de DBO obtidos em frascos com adição de 2,5 e $4,0 \mathrm{mg} / \mathrm{L}$ de ácido fólico, comparados a frascos controle

\begin{tabular}{|c|c|c|c|c|c|c|c|c|}
\hline $\begin{array}{c}\text { DATA } \\
\text { INCUBAÇÃO }\end{array}$ & $\begin{array}{c}\text { DATA } \\
\text { LEITURA }\end{array}$ & $\begin{array}{l}\text { CONDIÇÃO DOS } \\
\text { FRASCOS }\end{array}$ & $\begin{array}{l}\text { VOLUME } \\
\text { AMOSTRA }\end{array}$ & $\begin{array}{l}\text { CONSUMO } \\
\text { OXIGÊNIO (\%) }\end{array}$ & $\begin{array}{c}\text { CONSUMO } \\
\text { MÉDIO DE O2 } \\
(\%)- \\
\text { (duplicatas) } \\
\end{array}$ & $\begin{array}{l}\text { DESVIO } \\
\text { PADRÃO }\end{array}$ & DBO & $\begin{array}{l}\text { DBO média } \\
\text { (duplicatas) }\end{array}$ \\
\hline \multirow{6}{*}{ 09/02/04 } & \multirow{6}{*}{$10 / 02 / 04$} & \multirow[t]{2}{*}{ CONTROLE } & \multirow{6}{*}{$0,5 \mathrm{ml}$} & 9 & \multirow[t]{2}{*}{10} & \multirow[t]{2}{*}{1} & 401 & \multirow[t]{2}{*}{424} \\
\hline & & & & 11 & & & 447 & \\
\hline & & $\mathrm{C} / 2,5 \mathrm{mg} / \mathrm{L} \mathrm{AF}$ & & & \multirow[t]{2}{*}{10} & \multirow[t]{2}{*}{1} & 421 & \multirow[t]{2}{*}{445} \\
\hline & & & & 11 & & & 469 & \\
\hline & & \multirow{2}{*}{$\mathrm{C} / 4,0 \mathrm{mg} / \mathrm{L} \mathrm{AF}$} & & 12 & \multirow{2}{*}{13} & \multirow{2}{*}{1} & 536 & \multirow{2}{*}{539} \\
\hline & & & & 13 & & & 542 & \\
\hline \multirow{5}{*}{ 09/02/04 } & \multirow{5}{*}{$11 / 02 / 04$} & CONTROLE & \multirow{5}{*}{$0,5 \mathrm{ml}$} & $\begin{array}{l}20 \\
*\end{array}$ & 20 & 0 & $\begin{array}{c}901 \\
*\end{array}$ & 901 \\
\hline & & $\mathrm{C} / 2,5 \mathrm{mg} / \mathrm{L} \mathrm{AF}$ & & 24 & \multirow[t]{2}{*}{23} & \multirow[t]{2}{*}{1} & 1110 & \multirow[t]{2}{*}{1073} \\
\hline & & & & 23 & & & 1035 & \\
\hline & & \multirow[t]{2}{*}{$\mathrm{C} / 4,0 \mathrm{mg} / \mathrm{L} \mathrm{AF}$} & & 27 & \multirow[t]{2}{*}{26} & \multirow[t]{2}{*}{1} & 1152 & \multirow[t]{2}{*}{1137} \\
\hline & & & & 26 & & & 1121 & \\
\hline \multirow{6}{*}{ 09/02/04 } & \multirow{6}{*}{$12 / 02 / 04$} & CONTROLE & & 26 & 27 & 1 & 1092 & 1142 \\
\hline & & & & 27 & & & 1193 & \\
\hline & & $\mathrm{C} / 2,5 \mathrm{mg} / \mathrm{L} \mathrm{AF}$ & $0,5 \mathrm{ml}$ & 31 & 30 & 1 & 1253 & 1243 \\
\hline & & & & 29 & & & 1232 & \\
\hline & & $\mathrm{C} / 4,0 \mathrm{mg} / \mathrm{L} \mathrm{AF}$ & & 32 & 32 & 0 & 1348 & 1333 \\
\hline & & & & 32 & & & 1319 & \\
\hline & & CONTROLE & & 37 & 37 & 1 & 1621 & 1612 \\
\hline & & & & 36 & & & 1603 & \\
\hline 09/02/04 & $13 / 02 / 04$ & $\mathrm{C} / 2,5 \mathrm{mg} / \mathrm{L} \mathrm{AF}$ & $0,5 \mathrm{ml}$ & * & 41 & 0 & * & 1750 \\
\hline & & & & 41 & & & 1750 & \\
\hline & & $\mathrm{C} / 4,0 \mathrm{mg} / \mathrm{L} \mathrm{AF}$ & & 42 & 44 & 2 & 1687 & 1815 \\
\hline & & & & 46 & & & 1944 & \\
\hline & & CONTROLE & & 41 & 39 & 2 & 1770 & 1691 \\
\hline & & & & 37 & & & 1611 & \\
\hline 09/02/04 & $14 / 02 / 04$ & $\mathrm{C} / 2,5 \mathrm{mg} / \mathrm{L} \mathrm{AF}$ & $0,5 \mathrm{ml}$ & 46 & 46 & 0 & 1925 & 1928 \\
\hline & & & & 46 & & & 1932 & \\
\hline & & $\mathrm{C} / 4,0 \mathrm{mg} / \mathrm{L} \mathrm{AF}$ & & 51 & 50 & 1 & 2079 & 2138 \\
\hline & & & & 49 & & & 2196 & \\
\hline
\end{tabular}

Nota: * Dados não considerados devido a problemas ocorridos durante a análise. 
Tabela 31 - Bioensaio de respirometria 4, apresentando os resultados de consumo de oxigênio e de DBO obtidos em frascos com adição de 0,5;2,5 e 4,0 mg/L de ácido fólico, comparados a frascos controle

\begin{tabular}{|c|c|c|c|c|c|c|c|c|}
\hline $\begin{array}{c}\text { DATA } \\
\text { INCUBAÇÃO }\end{array}$ & $\begin{array}{c}\text { DATA } \\
\text { LEITURA }\end{array}$ & $\begin{array}{l}\text { CONDIÇÃO DOS } \\
\text { FRASCOS }\end{array}$ & $\begin{array}{l}\text { VOLUME } \\
\text { AMOSTRA }\end{array}$ & $\begin{array}{c}\text { CONSUMO } \\
\text { OXIGÊNIO (\%) }\end{array}$ & $\begin{array}{c}\text { CONSUMO } \\
\text { MÉDIO DE O2 } \\
(\%) \\
\text { (duplicatas) }\end{array}$ & $\begin{array}{l}\text { DESVIO } \\
\text { PADRÃO }\end{array}$ & DBO & $\begin{array}{l}\text { DBO média } \\
\text { (duplicatas) }\end{array}$ \\
\hline \multirow{8}{*}{$15 / 03 / 04$} & \multirow{8}{*}{$16 / 03 / 04$} & \multirow{2}{*}{ CONTROLE } & & 24 & \multirow{2}{*}{24} & \multirow{2}{*}{1} & 1014 & \multirow{2}{*}{1029} \\
\hline & & & & 25 & & & 1045 & \\
\hline & & \multirow{2}{*}{$\mathrm{C} / 0,5 \mathrm{mg} / \mathrm{L} \mathrm{AF}$} & & 23 & \multirow{2}{*}{25} & \multirow{2}{*}{1} & 1044 & \multirow{2}{*}{1055} \\
\hline & & & $05 \mathrm{ml}$ & 26 & & & 1065 & \\
\hline & & \multirow{2}{*}{$\mathrm{C} / 2,5 \mathrm{mg} / \mathrm{L} \mathrm{AF}$} & & 27 & \multirow{2}{*}{26} & \multirow{2}{*}{1} & 1222 & \multirow{2}{*}{1169} \\
\hline & & & & 25 & & & 1116 & \\
\hline & & \multirow{2}{*}{$\mathrm{C} / 4,0 \mathrm{mg} / \mathrm{L} \mathrm{AF}$} & & 24 & \multirow{2}{*}{24} & \multirow{2}{*}{1} & 1019 & \multirow{2}{*}{995} \\
\hline & & & & 25 & & & 971 & \\
\hline \multirow{8}{*}{$15 / 03 / 04$} & \multirow{8}{*}{$17 / 03 / 04$} & \multirow{2}{*}{ CONTROLE } & & 32 & \multirow{2}{*}{31} & \multirow{2}{*}{1} & 1429 & \multirow{2}{*}{1387} \\
\hline & & & & 30 & & & 1345 & \\
\hline & & $\mathrm{C} / 0.5 \mathrm{mg} / \mathrm{AF}$ & & 33 & 33 & 0 & 1481 & 1170 \\
\hline & & 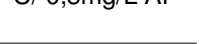 & $05 \mathrm{ml}$ & 33 & 00 & 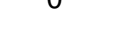 & 1478 & 1470 \\
\hline & & $\mathrm{C} / 25 \mathrm{mg} / \mathrm{AF}$ & & 34 & 35 & 1 & 1573 & 1563 \\
\hline & & 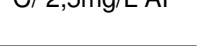 & & 35 & 30 & 1 & 1553 & 1000 \\
\hline & & $\mathrm{C} / 4.0 \mathrm{mg} / \mathrm{AF}$ & & 35 & 34 & 1 & 1457 & 1428 \\
\hline & & 然 & & 33 & ד & 1 & 1398 & (1) \\
\hline & & CONTROIF & & 41 & 42 & 1 & 1776 & 1833 \\
\hline & & SOTIRULL & & 43 & $4 c$ & 1 & 1891 & 1000 \\
\hline & & $\mathrm{C} / 0.5 \mathrm{mg} / \mathrm{LAF}$ & & 43 & 44 & 1 & 1928 & 1945 \\
\hline $15 / 03 / 04$ & $18 / 03 / 04$ & 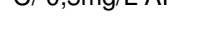 & $5 \mathrm{ml}$ & 44 & 74 & 1 & 1963 & טדם \\
\hline & & $\mathrm{C} / 25 \mathrm{mal} \triangle \mathrm{F}$ & & 49 & 10 & 1 & 1961 & 2013 \\
\hline & & 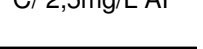 & & 48 & 40 & 1 & 2066 & 2010 \\
\hline & & $\mathrm{C} / 40 \mathrm{mg} / \mathrm{l} \mathrm{AF}$ & & 58 & 55 & 3 & 2318 & 2261 \\
\hline & & 保 & & 52 & J & $\checkmark$ & 2205 & $2<01$ \\
\hline & & CONTROIF & & 49 & 18 & 1 & 2158 & 2140 \\
\hline & & UUTI TULE & & 47 & 40 & 1 & 2140 & 2145 \\
\hline & & $\mathrm{C} / 0.5 \mathrm{mg} / \mathrm{L}$ AF & & 53 & 52 & 1 & 2392 & 2325 \\
\hline $15 / 03 / 04$ & $19 / 03 / 04$ & & $0.5 \mathrm{ml}$ & 51 & L & & 2259 & \\
\hline & & $\mathrm{C} / 25 \mathrm{mg} / \mathrm{LAF}$ & & 65 & 64 & 1 & 2733 & 2693 \\
\hline & & & & 63 & 04 & 1 & 2654 & 2000 \\
\hline & & $\mathrm{C} / 4.0 \mathrm{mg} / \mathrm{L} \mathrm{AF}$ & & 64 & 61 & 2 & 2728 & 2590 \\
\hline & & & & 59 & & & 2451 & \\
\hline & & CONTROIF & & 54 & 54 & 0 & 2400 & 2388 \\
\hline & & 告TVIIULL & & 54 & 24 & 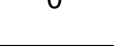 & 2376 & 2000 \\
\hline & & $\mathrm{C} / 0.5 \mathrm{mg} / \mathrm{LAF}$ & & 54 & 54 & 0 & 2514 & 2507 \\
\hline $15 / 03 / 04$ & $20 / 03 / 04$ & & $0.5 \mathrm{ml}$ & 54 & 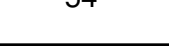 & 0 & 2499 & 200 \\
\hline & & $\mathrm{C} / 25 \mathrm{mal} \triangle \mathrm{F}$ & & 74 & 75 & 0 & 3214 & 3052 \\
\hline & & 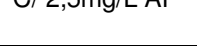 & & 75 & 10 & 0 & 2893 & 3000 \\
\hline & & $\mathrm{C} / 4.0 \mathrm{mg} / \mathrm{L} \mathrm{AF}$ & & 76 & 78 & 2 & 3042 & 3280 \\
\hline & & & & 79 & & & 3519 & \\
\hline
\end{tabular}


Tabela 32 - Bioensaio de respirometria 5, apresentando os resultados de consumo de oxigênio e de DBO obtidos em frascos com adição de 2,5 mg/L de ácido fólico e 2,5 mg/L de Dosfolat, comparados a frascos controle

\begin{tabular}{|c|c|c|c|c|c|c|c|c|}
\hline $\begin{array}{c}\text { DATA } \\
\text { INCUBAÇÃO }\end{array}$ & $\begin{array}{c}\text { DATA } \\
\text { LEITURA }\end{array}$ & $\begin{array}{l}\text { CONDIÇÃO DOS } \\
\text { FRASCOS }\end{array}$ & $\begin{array}{l}\text { VOLUME } \\
\text { AMOSTRA }\end{array}$ & $\begin{array}{l}\text { CONSUMO } \\
\text { OXIGÊNIO (\%) }\end{array}$ & $\begin{array}{c}\text { CONSUMO } \\
\text { MÉDIO DE O2 } \\
(\%) \\
\text { (duplicatas) }\end{array}$ & $\begin{array}{l}\text { DESVIO } \\
\text { PADRÃO }\end{array}$ & DBO & $\begin{array}{l}\text { DBO média } \\
\text { (duplicatas) }\end{array}$ \\
\hline \multirow{6}{*}{$30 / 03 / 04$} & \multirow{6}{*}{$31 / 03 / 04$} & \multirow{2}{*}{ CONTROLE } & \multirow{6}{*}{$0,5 \mathrm{ml}$} & 6 & \multirow{2}{*}{7} & \multirow{2}{*}{1} & 252 & \multirow{2}{*}{271} \\
\hline & & & & 7 & & & 291 & \\
\hline & & & & 6 & \multirow{2}{*}{6} & \multirow{2}{*}{0} & 278 & \multirow{2}{*}{264} \\
\hline & & C/ $2,5 \mathrm{mg} / \mathrm{L}$ AF & & 6 & & & 251 & \\
\hline & & \multirow{2}{*}{$\mathrm{C} / 2,5 \mathrm{mg} / \mathrm{L}$ Dosfolat } & & 60 & \multirow{2}{*}{62} & \multirow{2}{*}{2} & 2498 & \multirow{2}{*}{2496} \\
\hline & & & & 64 & & & 2494 & \\
\hline \multirow{6}{*}{$30 / 03 / 04$} & \multirow{6}{*}{$01 / 04 / 04$} & \multirow{2}{*}{ CONTROLE } & \multirow{6}{*}{$0,5 \mathrm{ml}$} & 20 & \multirow{2}{*}{20} & \multirow{2}{*}{0} & 849 & \multirow{2}{*}{860} \\
\hline & & & & 20 & & & 871 & \\
\hline & & $\mathrm{C} / 25 \mathrm{mg} / \mathrm{AF}$ & & 24 & \multirow{2}{*}{24} & \multirow{2}{*}{0} & 1045 & \multirow{2}{*}{1017} \\
\hline & & & & 24 & & & 990 & \\
\hline & & \multirow{2}{*}{$\mathrm{C} / 2,5 \mathrm{mg} / \mathrm{L}$ Dosfolat } & & 99 & \multirow{2}{*}{99} & \multirow{2}{*}{0} & 3973 & \multirow{2}{*}{4036} \\
\hline & & & & 99 & & & 4099 & \\
\hline \multirow{6}{*}{$30 / 03 / 04$} & & & & 43 & & 1 & 1742 & 1707 \\
\hline & & S & & 40 & 41 & 1 & 1712 & $17 / 2 \pi$ \\
\hline & 02/04/04 & $\mathrm{C} / 2.5 \mathrm{mg} / \mathrm{L} \mathrm{AF}$ & $0,5 \mathrm{ml}$ & 48 & 48 & 1 & 2036 & 2053 \\
\hline & & & & 49 & & & 2070 & \\
\hline & & $\mathrm{c} / 25 \mathrm{ma} / \mathrm{L}$ Dosfolat & & 99 & 99 & 0 & 4003 & 4043 \\
\hline & & & & 99 & & & 4083 & \\
\hline & & CONTROIF & & 57 & 56 & 1 & 2404 & 2418 \\
\hline & & 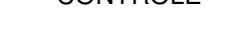 & & 56 & 30 & & 2432 & \\
\hline $30 / 03 / 04$ & $03 / 04 / 04$ & $\mathrm{c} / 25 \mathrm{mg} / \mathrm{AF}$ & $05 \mathrm{ml}+2$ & 65 & 65 & 0 & 2812 & 2707 \\
\hline $30 / 00 / 04$ & $00 / 04 / 04$ & C/ 2,5mg/L AF & $0,5 \mathrm{ml}$ & 65 & 65 & 0 & 2762 & 2101 \\
\hline & & $\mathrm{c} / 25 \mathrm{mall}$ Rocfolat & & 98 & OQ & 0 & 3907 & 2010 \\
\hline & & 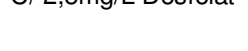 & & 99 & 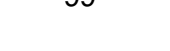 & 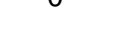 & 3713 & (0) \\
\hline & & & & 61 & & & 2641 & \\
\hline & & & & 46 & & 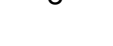 & 1967 & \\
\hline $30 / 03 / 04$ & $04 / 04 / 04$ & $\mathrm{c} / 25 \mathrm{ma} / \mathrm{LAF}$ & $0.5 \mathrm{ml}$ & 68 & 67 & 1 & 3084 & 3009 \\
\hline & & & & 66 & & & 2934 & \\
\hline & & $\mathrm{c} / 25 \mathrm{mg} / \mathrm{l}$ Dosfolat & & 100 & 100 & 0 & 3596 & 3746 \\
\hline & & & & 100 & & & 3896 & \\
\hline
\end{tabular}

